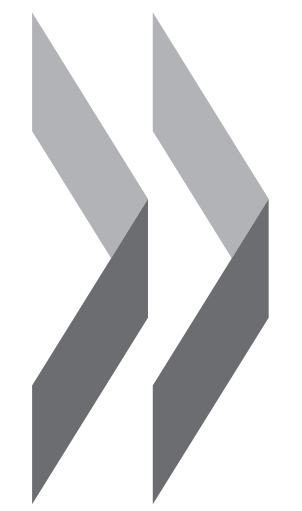

\title{
Entrepreneurship at a Glance 2012
}

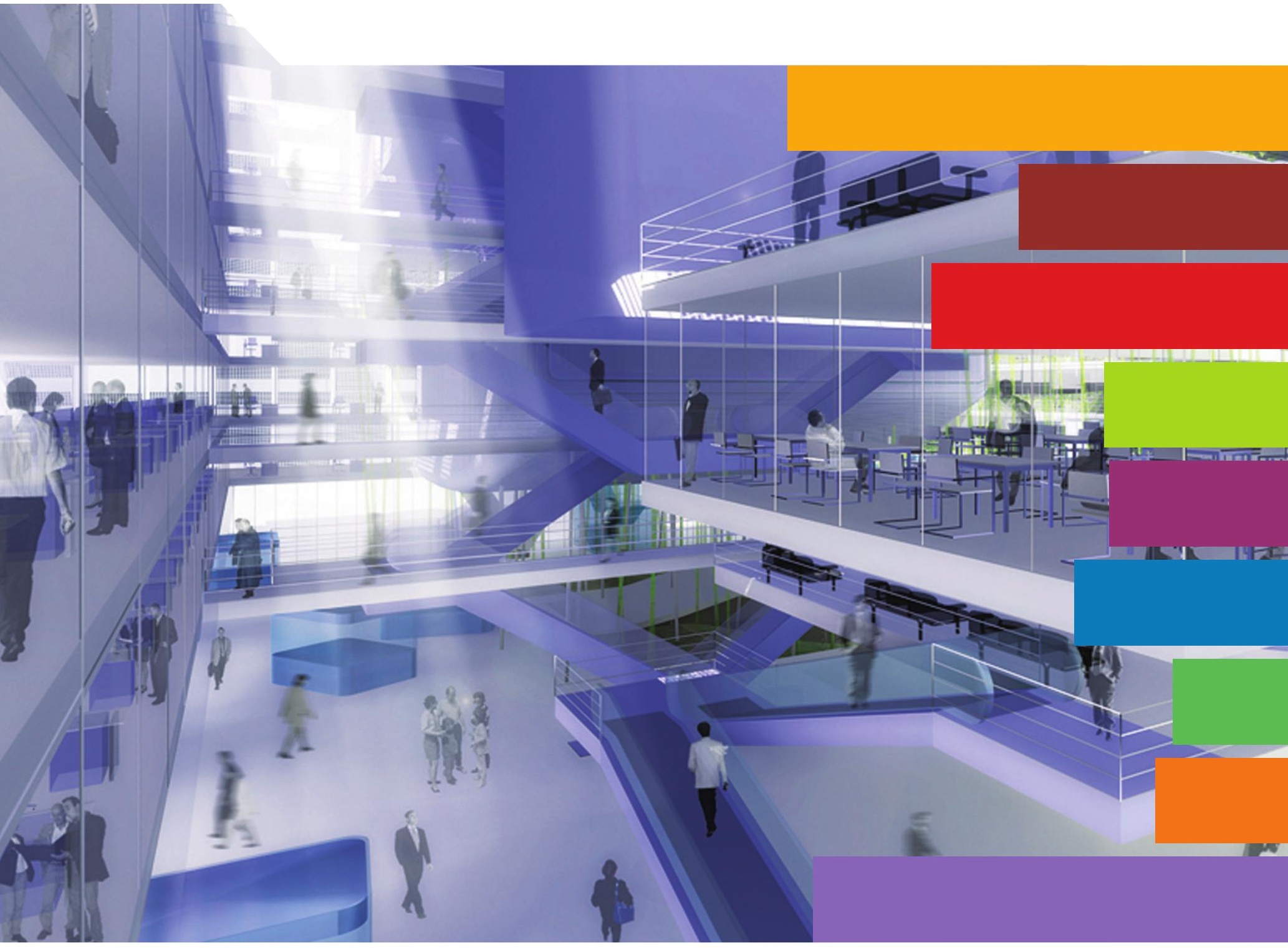

(2)》OECD 



\section{Entrepreneurship at a Glance 2012}


This work is published on the responsibility of the Secretary-General of the OECD. The opinions expressed and arguments employed herein do not necessarily reflect the official views of the Organisation or of the governments of its member countries.

This document and any map included herein are without prejudice to the status of or sovereignty over any territory, to the delimitation of international frontiers and boundaries and to the name of any territory, city or area.

\section{Please cite this publication as:}

OECD (2012), Entrepreneurship at a Glance 2012, OECD Publishing.

http://dx.doi.org/10.1787/entrepreneur_aag-2012-en

ISBN 978-92-64-17309-5 (print)

ISBN 978-92-64-17310-1 (HTML)

Annual: Entrepreneurship at a Glance

ISSN 2226-6933 (print)

ISSN 2226-6941 (online)

The statistical data for Israel are supplied by and under the responsibility of the relevant Israeli authorities. The use of such data by the OECD is without prejudice to the status of the Golan Heights, East Jerusalem and Israeli settlements in the West Bank under the terms of international law.

Photo credits:

Cover: ๑ Jacques Ferrier architectures/image Ferrier Production. "Concept Office, immeuble de bureaux prototype à haute qualité environnementale conçu par Jacques Ferrier Architectures en partenariat avec EDF".

Chapters : ๑ Philippe Mairesse / Devizu.

Corrigenda to OECD publications may be found on line at: www.oecd.org/publishing/corrigenda.

(c) OECD 2012

You can copy, download or print OECD content for your own use, and you can include excerpts from OECD publications, databases and multimedia products in your own documents, presentations, blogs, websites and teaching materials, provided that suitable acknowledgement of OECD as source and copyright owner is given. All requests for public or commercial use and translation rights should be submitted to rights@oecd.org. Requests for permission to photocopy portions of this material for public or commercial use shall be addressed directly to the Copyright Clearance Center (CCC) at info@copyright.com or the Centre français d'exploitation du droit de copie (CFC) at contact@cfcopies.com. 


\section{Preface}

E most entrepreneurship research relied on ad hoc data compilations developed to support specific projects and virtually no official statistics on the subject existed. The collection of harmonised indicators presented in this publication is the result of the OECD-Eurostat Entrepreneurship Indicators Programme (EIP). The programme, started in 2006, is the first attempt to compile and publish international data on entrepreneurship from official statistical sources. Indeed, to meet the challenge of providing new entrepreneurship indicators, while minimising costs for national statistical offices and burden on business, the programme focuses attention on exploiting existing data sources, e.g. statistical business registers, rather than developing new business surveys.

Informing policy design through the development of policy-relevant indicators is at the core of the EIP programme, and much attention is paid to responding to information needs in emerging areas of interest. This issue of Entrepreneurship at a Glance presents new work on women entrepreneurship undertaken by the EIP as part of the OECD Gender Initiative, whose aim is to promote gender equality in "the three E's", Education, Employment and Entrepreneurship. The lack of solid and reliable information on women entrepreneurship constitutes a challenge when considering how to boost entrepreneurship among women. The EIP investigated how to meaningfully measure women entrepreneurship, and proposed a methodology for producing indicators on entrepreneurship by gender of the enterprise owner. This resulted in a new collection of original gender-specific statistics to help governments create a more level playing field and promote equality.

The global financial crisis has highlighted the need for more timely information on the situation of small businesses. This edition of Entrepreneurship at a Glance includes new data on firm creations and bankruptcies, adding to the set of timely entrepreneurship indicators collected by the EIP. This is just the beginning: further developments in this area will be presented in future editions of this publication.

This report is divided into two parts. The first presents conceptual and methodological issues related to the gender dimension of entrepreneurship and the measurement of indicators for entrepreneurial finance.

The second part provides detailed indicators of entrepreneurial performance, including structural data of the enterprise population and indicators of business demography, and a special section devoted to gender-specific entrepreneurship indicators. This part also contains a selection of indicators of entrepreneurial determinants.

The publication was prepared in the Trade and Business Statistics Division of the OECD Statistics Directorate by Mario Piacentini, Blandine Serve, Gueram Sargsyan and Annamaria Tuske under the leadership of Mariarosa Lunati. Manfred Schmiemann and Perrine Bamps, and Aleksandra Stawinska of Eurostat contributed respectively to Chapter 2 and to the compilation 
of the indicators of entrepreneurial performance. Particular thanks go to experts in National Statistical Offices who contributed data and time to produce the original indicators for Austria, Belgium, Brazil, Bulgaria, Canada, the Czech Republic, Denmark, Estonia, Finland, France, Germany, Hungary, Israel, Italy, Japan, Korea, Latvia, Lithuania, Luxembourg, Mexico, the Netherlands, New Zealand, Norway, Poland, Portugal, Romania, the Slovak Republic, Slovenia, Spain, Sweden, Switzerland and the United States.

Martine Durand

Chief Statistician and Director of the OECD Statistics Directorate

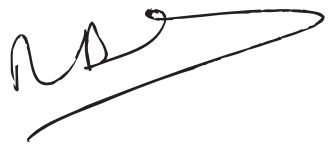




\section{Table of Contents}

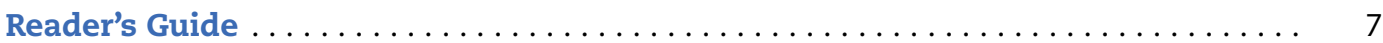

Recent Trends in New Firm Creations and Bankruptcies................ 11

Part I

MEASURING ENTREPRENEURSHIP

Chapter 1. Measuring Women Entrepreneurship.................... 21

Defining the entrepreneur: Conceptual and measurement issues ......... 22

Measurement issues, data and options for the development of gender indicators 25

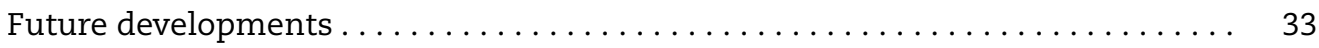

Notes........................................ 34

References .......................................... 34

Chapter 2. Measuring Entrepreneurial Finance: A European Survey of SMEs . . . . 37

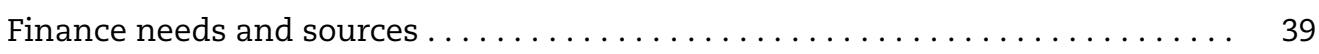

Towards internationally harmonised indicators $\ldots \ldots \ldots \ldots \ldots \ldots \ldots \ldots . \ldots 7$

Notes. . . . . . . . . . . . . . . . . . . . . . . . . . . . . . . . 48

References ....................................... 48

Part II

ENTREPRENEURSHIP INDICATORS

3. Structural Indicators on the Enterprise Population $\ldots \ldots \ldots \ldots \ldots \ldots \ldots \ldots$

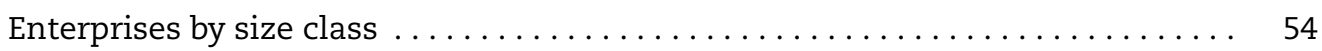

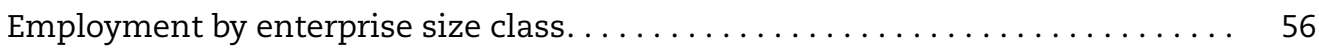

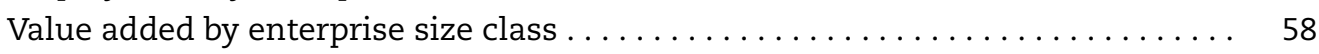

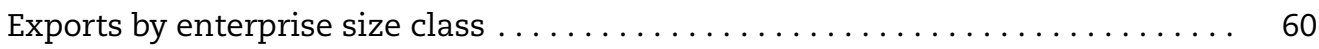

4. Enterprise Birth, Death and Survival $\ldots \ldots \ldots \ldots \ldots \ldots \ldots \ldots \ldots \ldots \ldots \ldots \ldots \ldots \ldots$

Birth rate of employer enterprises . . . . . . . . . . . . . . . . . . . . 64

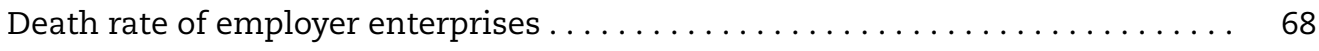

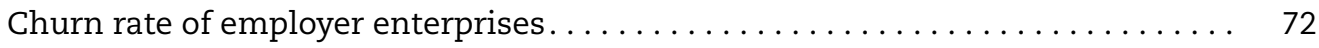

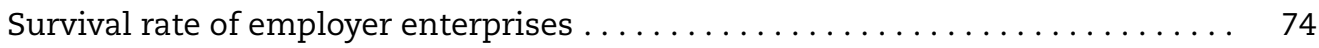

5. Employment Creation and Destruction $\ldots \ldots \ldots \ldots \ldots \ldots \ldots \ldots \ldots \ldots$

Employment creation and destruction by employer enterprise births and deaths . . 80

Employment creation and destruction in surviving enterprises.......... 82 


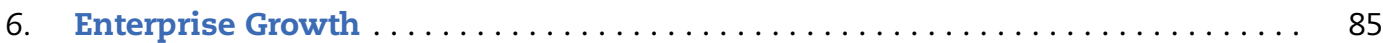

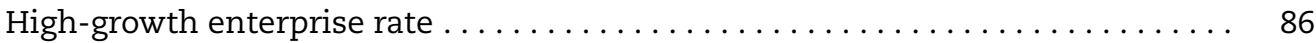

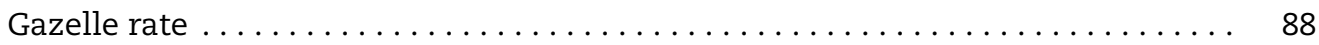

7. Women Entrepreneurship $\ldots \ldots \ldots \ldots \ldots \ldots \ldots \ldots \ldots \ldots \ldots \ldots \ldots \ldots$

Employers and own-account workers by gender . . . . . . . . . . . . 92

Share, size and industry of women-owned enterprises . . . . . . . . . . 94

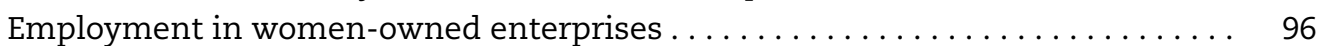

Birth and death rates of women-owned enterprises. . . . . . . . . . . 98

Survival and employment growth of women-owned enterprises . . . . . . . . 100

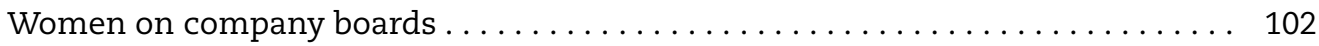

8. Determinants of Entrepreneurship: Selected Indicators . . . . . . . . . . 105

Regulatory framework: Starting a business . . . . . . . . . . . . . . 106

Access to finance: Success rate in obtaining finance . . . . . . . . . . . 108

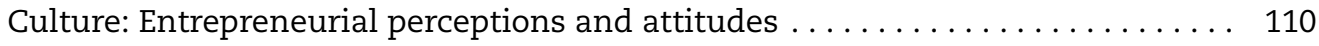

Annex A. List of Indicators of Entrepreneurial Determinants . . . . . . . . . . . . 113

Annex B. Eurostat's 2010 Survey Questionnaire on Access to Finance . . . . . . . . . . 118

Annex C. Grossing up Techniques . . . . . . . . . . . . . . . . . . . . 133

\section{This book has...}

\section{队l from the printed page!}

Look for the StatLinks at the bottom right-hand corner of the tables or graphs in this book. To download the matching Excel $^{\circledR}$ spreadsheet, just type the link into your Internet browser, starting with the $h t t p: / / d x . d o i . o r g$ prefix.

If you're reading the PDF e-book edition, and your PC is connected to the Internet, simply click on the link. You'll find StatLinks appearing in more OECD books. 


\section{Reader's Guide}

$\mathrm{T}$

his publication presents indicators of entrepreneurship collected by the OECD-Eurostat Entrepreneurship Indicators Programme (EIP). Started in 2006, the programme develops multiple measures of entrepreneurship and its determinants according to a simplified conceptual framework that distinguishes between the manifestation of entrepreneurship, the factors that influence it, and the impacts of entrepreneurship on the economy or society. A set of indicators of entrepreneurial performance is proposed for understanding and comparing the extent and type of entrepreneurship that take place in different countries. This approach reflects the idea that analysts should go beyond enterprise creation or any other single measure to study entrepreneurship as entrepreneurs and entrepreneurial forces can be found in many existing businesses. Understanding the dynamism these actors exert on the economy is as important as understanding the dynamics of start-ups.

The indicators of entrepreneurial performance are presented for the following countries: Austria, Belgium, Brazil, Bulgaria, Canada, the Czech Republic, Denmark, Estonia, Finland, Germany, Hungary, Japan, Korea, Israel, Italy, Latvia, Lithuania, Luxembourg, Mexico, the Netherlands, New Zealand, Norway, Poland, Portugal, Romania, the Slovak Republic, Slovenia, Spain, Sweden, Switzerland and the United States.

A selection of indicators of determinants of entrepreneurship is also included in the publication: the choice of the indicators was based on their novelty, i.e. they were recently produced and or/updated. Annex A presents a comprehensive list of indicators of determinants and the corresponding data sources.

Each indicator is accompanied by a short text that explains what is measured and provides the policy context. A detailed description of the definition and explanations of the comparability of the indicator across countries are also included.

\section{Data collection}

The set of indicators that are part of the EIP framework have not all reached the same degree of development. Some of them are well established components of regular data collections, while others are only developed in a restricted number of countries and their harmonised definition forms the object of discussion. The indicators presented in this publication reflect this diversity:
A) Enterprises by size class.
B) Employment by enterprise size class.
C) Value added by enterprise size class.
D) Exports by enterprise size class.
E) Birth rate of employer enterprises.
F) Death rate of employer enterprises. 
G) Churn rate of employer enterprises.

H) Survival rate of employer enterprises.

I) Employment creation and destruction by employer enterprise births and deaths.

J) Employment creation and destruction in surviving enterprises.

K) High-growth enterprise rate.

L) Gazelle rate.

M) Employers and own account workers by gender.

N) Share, size and industry of women-owned enterprises.

O) Employment in women-owned enterprises.

P) Birth and death rates of women-owned enterprises.

Q) Survival and employment growth of women-owned enterprises .

R) Women on company boards.

S) Regulatory framework: Starting a business.

T) Access to finance: Success rate in obtaining finance.

U) Culture: Entrepreneurial perceptions and attitudes.

For indicators $\mathrm{A}, \mathrm{B}, \mathrm{C}$, and $\mathrm{E}$ to $\mathrm{L}$ the source is the OECD Structural and Demographic Business Statistics (SDBS) Database. Indicators A to C refer to Structural Business Statistics, while Indicators $\mathrm{E}$ to $\mathrm{L}$, i.e. the core indicators of entrepreneurial performance, consist of Business Demography data. Indicator D originates from the OECD Trade by Enterprise Characteristics (TEC) Database. SDBS and TEC data are collected annually via harmonised questionnaires to National Statistical Offices. Switzerland uses three additional criteria in the definitions. First, enterprises need to have at least one establishment operation more than 20 hours per week. Second, individuals are classified as persons employed or employees only if they work more than 6 hours per week. Third, the number of employees is calculated by subtracting an estimate of the number of working proprietors to the number of persons employed.

The indicators on women's entrepreneurship (Indicators $\mathrm{M}$ to $\mathrm{R}$ ) present preliminary results from a new data collection started by the EIP. The data for Indicators $\mathrm{N}$ to $\mathrm{Q}$ have been produced by national statistical offices following definitions already in use for employer business demography. Not all countries, however, could use business registers to produce the indicators; representative business surveys and economic census data were thus used. Indicator $\mathrm{R}$ is based on company-level commercial data.

The remaining indicators represent a selection of determinants of entrepreneurship, chosen for their novelty. The sources of data are diverse and include both data from National Statistical Offices and other sources.

\section{Size-class breakdown}

Structural Business Statistics indicators usually focus on five size classes based on the number of persons employed, where the data across countries and variables can be most closely aligned: 1-9, 10-19, 20-49, 50-249, 250+. Not all country information fits perfectly into this classification, however, and divergence from these target size classes are reported in each chapter. 
For Business Demography data, the typical collection breakdown is $1-4,5-9,10+$ to reflect the fact that a vast majority of newly created enterprises are micro enterprises.

\section{Activity breakdown}

For Business Demography indicators, a breakdown by activity is also proposed. Data are usually broken down into manufacturing and services industries.

Manufacturing comprises: mining and quarrying; manufacturing; electricity, gas and water.

Services comprise: wholesale and retail trade; hotels and restaurants; transport, storage and communications; financial intermediation; real estate, renting and business activities.

For the employer enterprise birth and death rates, data are also presented for the following industries: food products, beverages and tobacco; electrical and optical equipment; trade; other business services.

\section{The EIP Framework}

Entrepreneurship is defined by the EIP as the phenomenon associated with entrepreneurial activity, which is the enterprising human action in pursuit of the generation of value, through the creation or expansion of economic activity, by identifying and exploiting new products, processes or markets. In this sense, entrepreneurship is a phenomenon that manifests itself throughout the economy and in many different forms with many different outcomes, and these outcomes are not always related to the creation of financial wealth; for example, they may be related to increasing employment, tackling inequalities, or indeed, increasingly, environmental issues. The challenge of the EIP is to improve the understanding of these multiple manifestations. The programme recognises that no single indicator can ever adequately cover entrepreneurship, and it has therefore developed a set of measures that each captures a different aspect or different type of entrepreneurship; these measures are referred to as EIP indicators of entrepreneurial performance. There are currently some 20 performance indicators covered in the EIP.

The EIP takes a comprehensive approach to the measurement of entrepreneurship by looking not only at the manifestation of the entrepreneurial phenomenon but also at the factors that influence it. These factors range from the market conditions to the regulatory framework, to the culture or the conditions of access to finance. While some areas of determinants lend themselves more easily to measurement (for instance, the existence and restrictiveness of anti-trust law or the administrative costs to set-up a new business in a country), for other determinants the difficulty resides in finding suitable measures (e.g. venture capital and angel capital) and/or in comprehending the exact nature of their relationship with entrepreneurship (e.g. culture). The EIP aims to contribute to advance research on the less understood, less measurable determinants of entrepreneurship. 
The EIP Framework

\begin{tabular}{|c|c|c|c|c|c|c|c|}
\hline \multicolumn{6}{|c|}{ Determinants } & $\begin{array}{c}\text { Entrepreneurial } \\
\text { performance }\end{array}$ & Impact \\
\hline $\begin{array}{l}\text { Regulatory } \\
\text { framework }\end{array}$ & Market conditions & Access to finance & $\begin{array}{c}\text { Knowledge creation } \\
\text { and diffusion }\end{array}$ & $\begin{array}{l}\text { Entrepreneurial } \\
\text { capabilities }\end{array}$ & Culture & Firm based & Job creation \\
\hline $\begin{array}{l}\text { Administrative } \\
\text { burdens } \\
\text { for entry }\end{array}$ & Anti-trust laws & $\begin{array}{l}\text { Access to debt } \\
\text { financing }\end{array}$ & $\mathrm{R} \& \mathrm{D}$ investment & $\begin{array}{c}\text { Training } \\
\text { and experience } \\
\text { of entrepreneurs }\end{array}$ & $\begin{array}{l}\text { Risk attitude } \\
\text { in society }\end{array}$ & $\begin{array}{c}\text { Employment } \\
\text { based }\end{array}$ & Economic growth \\
\hline $\begin{array}{c}\text { Administrative } \\
\text { burdens for growth }\end{array}$ & Competition & Business angels & $\begin{array}{l}\text { University/industry } \\
\text { interface }\end{array}$ & $\begin{array}{l}\text { Business and } \\
\text { entrepreneurship } \\
\text { education (skills) }\end{array}$ & $\begin{array}{l}\text { Attitudes towards } \\
\text { entrepreneurs }\end{array}$ & Wealth & Poverty reduction \\
\hline $\begin{array}{l}\text { Bankruptcy } \\
\text { regulations }\end{array}$ & $\begin{array}{l}\text { Access to the } \\
\text { domestic market }\end{array}$ & Access to VC & $\begin{array}{l}\text { Technological } \\
\text { co-operation } \\
\text { between firms }\end{array}$ & $\begin{array}{l}\text { Entrepreneurship } \\
\text { infrastructure }\end{array}$ & $\begin{array}{l}\text { Desire } \\
\text { for business } \\
\text { ownership }\end{array}$ & & $\begin{array}{l}\text { Formalising } \\
\text { the informal } \\
\text { sector }\end{array}$ \\
\hline $\begin{array}{c}\text { Safety, health } \\
\text { and environmental } \\
\text { regulations }\end{array}$ & $\begin{array}{l}\text { Access to foreign } \\
\text { markets }\end{array}$ & $\begin{array}{l}\text { Access to other } \\
\text { types of equity }\end{array}$ & $\begin{array}{l}\text { Technology } \\
\text { diffusion }\end{array}$ & Immigration & $\begin{array}{l}\text { Entrepreneurship } \\
\text { education } \\
\text { (mindset) }\end{array}$ & & \\
\hline $\begin{array}{l}\text { Product } \\
\text { regulation }\end{array}$ & $\begin{array}{l}\text { Degree of public } \\
\text { involvement }\end{array}$ & Stock markets & $\begin{array}{l}\text { Broadband } \\
\text { access }\end{array}$ & & & & \\
\hline \multirow{2}{*}{$\begin{array}{l}\text { Labour market } \\
\text { regulation }\end{array}$} & \multirow{2}{*}{ Public procurement } & & & & & & \\
\hline & & & Firms & \multicolumn{2}{|c|}{ Employment } & \multicolumn{2}{|c|}{ Wealth } \\
\hline $\begin{array}{l}\text { Court and legal } \\
\text { framework }\end{array}$ & & \multirow{2}{*}{\multicolumn{2}{|c|}{ Employer enterprise birth rates }} & \multirow{2}{*}{\multicolumn{2}{|c|}{$\begin{array}{c}\text { Share of high growth firms } \\
\text { (by employment) }\end{array}$}} & \multirow{2}{*}{\multicolumn{2}{|c|}{$\begin{array}{l}\text { Share of high growth firms } \\
\text { (by turnover) }\end{array}$}} \\
\hline \multirow{2}{*}{$\begin{array}{l}\text { Social and health } \\
\text { security }\end{array}$} & & & & & & & \\
\hline & & \multicolumn{2}{|c|}{ Employer enterprise death rates } & \multicolumn{2}{|c|}{ Share of gazelles (employment) } & \multicolumn{2}{|c|}{ Share of gazelles (by turnover) } \\
\hline \multirow{2}{*}{$\begin{array}{c}\text { Income taxes; } \\
\text { wealth/bequest taxes }\end{array}$} & & \multicolumn{2}{|c|}{ Business churn } & \multicolumn{2}{|c|}{ Ownership rate start-ups } & \multicolumn{2}{|c|}{ Value added, young or small firms } \\
\hline & & \multicolumn{2}{|c|}{ Net business population growth } & \multicolumn{2}{|c|}{ Ownership rates business population } & \multicolumn{2}{|c|}{ Productivity contribution, young or small firms } \\
\hline \multirow{2}{*}{$\begin{array}{l}\text { Business and } \\
\text { capital taxes }\end{array}$} & \multirow{2}{*}{$\begin{array}{l}\text { Patent system; } \\
\text { standards }\end{array}$} & \multicolumn{2}{|c|}{ Survival rates at 3 and 5 years } & \multicolumn{2}{|c|}{ Employment in 3 and 5 year old firms } & \multicolumn{2}{|c|}{ Innovation performance, young or small firms } \\
\hline & & \multicolumn{2}{|c|}{ Proportion of 3 and 5 year old firms } & \multicolumn{2}{|c|}{ Average firm size after 3 and 5 years } & \multicolumn{2}{|c|}{ Export performance, young or small firms } \\
\hline
\end{tabular}


Entrepreneurship at a Glance 2012

(c) OECD 2012

\section{Recent Trends in New Firm Creations and Bankruptcies}

\section{Recent developments}

Start-ups are an important source of job creation in OECD economies. Monitoring them provides an important, timely, indicator of entrepreneurialism in an economy, particularly when coupled with other information, for example, the state of the overall labour market or measures introduced by governments to stimulate self-employment. It is important to note, when interpreting the data, that "push" factors (i.e. high structural unemployment) and "pull" factors (e.g. increased opportunities) can both play a role in high start-up rates.

At the height of the global economic crisis, start-up rates fell precipitously in all OECD countries where data are available. In subsequent quarters, start-up rates began picking up, toward pre-crisis levels, spectacularly so in France in response to the introduction of a simplified procedure to start-up an individual enterprise, namely the "régime de l'autoentrepreneur". In the first half of 2011, however, this momentum appeared to have stalled or slowed in most countries, but remained above the lows seen at the height of the crisis in all countries except Germany. In Spain, start-up rates continued to show a modest acceleration but they remained significantly below pre-crisis levels.

Tentative signs have emerged of a pick-up in the most recent periods, albeit based on data for only a few countries, with rates continuing to show relatively robust growth in Australia and the United Kingdom in the fourth quarter of 2011, and steady growth in Norway in the third quarter.

Bankruptcy rates can also provide timely indicators of entrepreneurship, although as is the case with timely start-up rates, some caveats are needed in interpretation and in comparing rates across countries and time. Indeed, different regulatory environments and insolvency procedures can distort comparisons and create lags between the time of an event that may lead to a bankruptcy and the actual recorded time of the bankruptcy. Despite these caveats, it is clear that the recent global crisis had an observable impact on the number of bankruptcies. Between the first quarter of 2008 and the second quarter of 2009 the number of bankruptcy procedures increased considerably in most countries for which data are available, and remained at relatively high levels throughout the first half of 2010. In Denmark and the United States the increase was exceptional, but rates have since begun to slow, albeit remaining at levels significantly above pre-crisis levels. In 


\section{Figure 0.1. New enterprises, selected countries}

Number of new enterprises, trend-cycle, $2006=100$
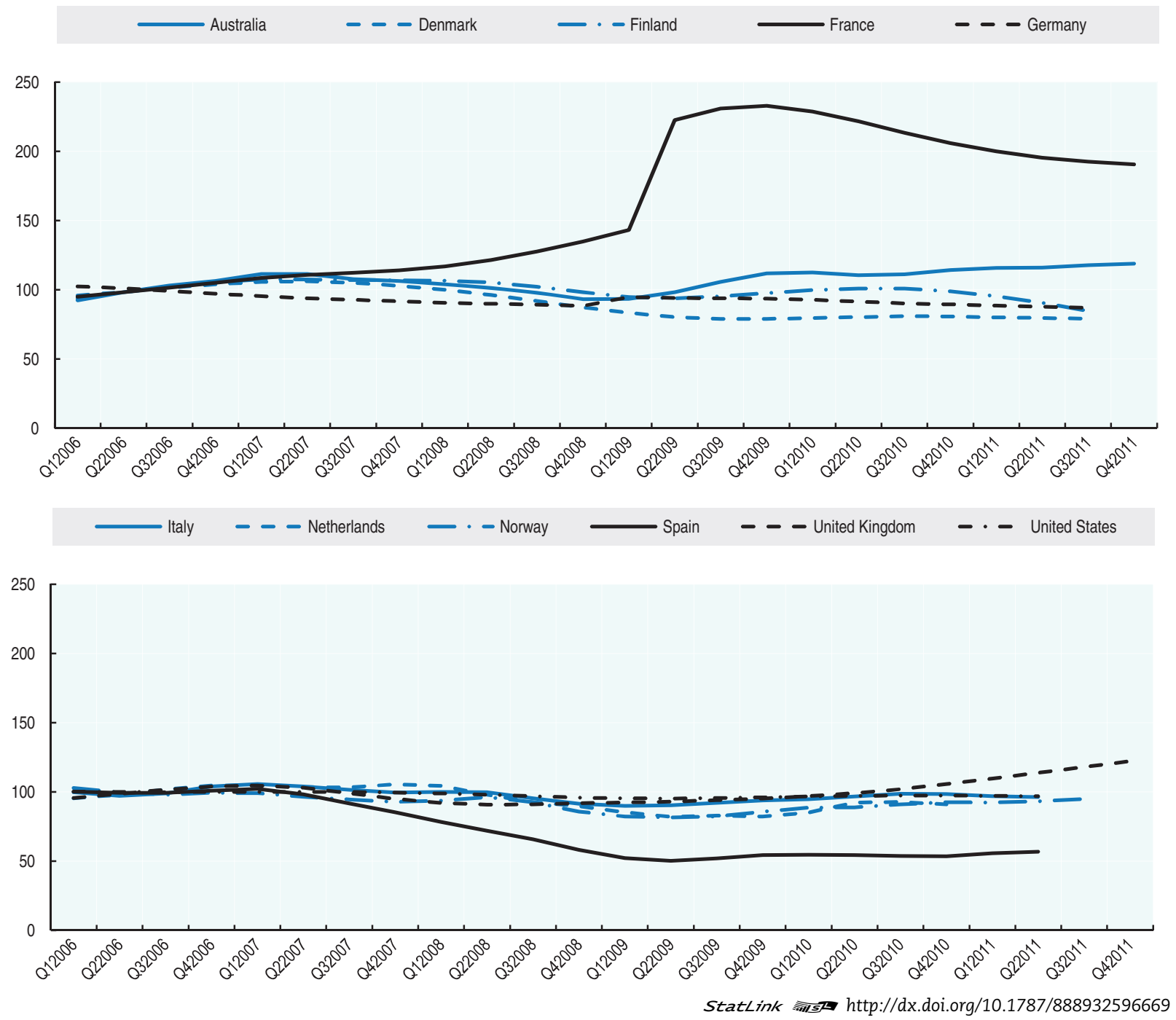

Iceland, however, rates have continued to grow significantly in recent periods. Rates have also continued to increase, albeit more modestly, in the United Kingdom and the Netherlands. Canada saw a steady downward trend in bankruptcy rates that even started before the crisis. 
Figure 0.2. Bankruptcies, selected countries

Number of bankruptcies, trend-cycle, $2006=100$
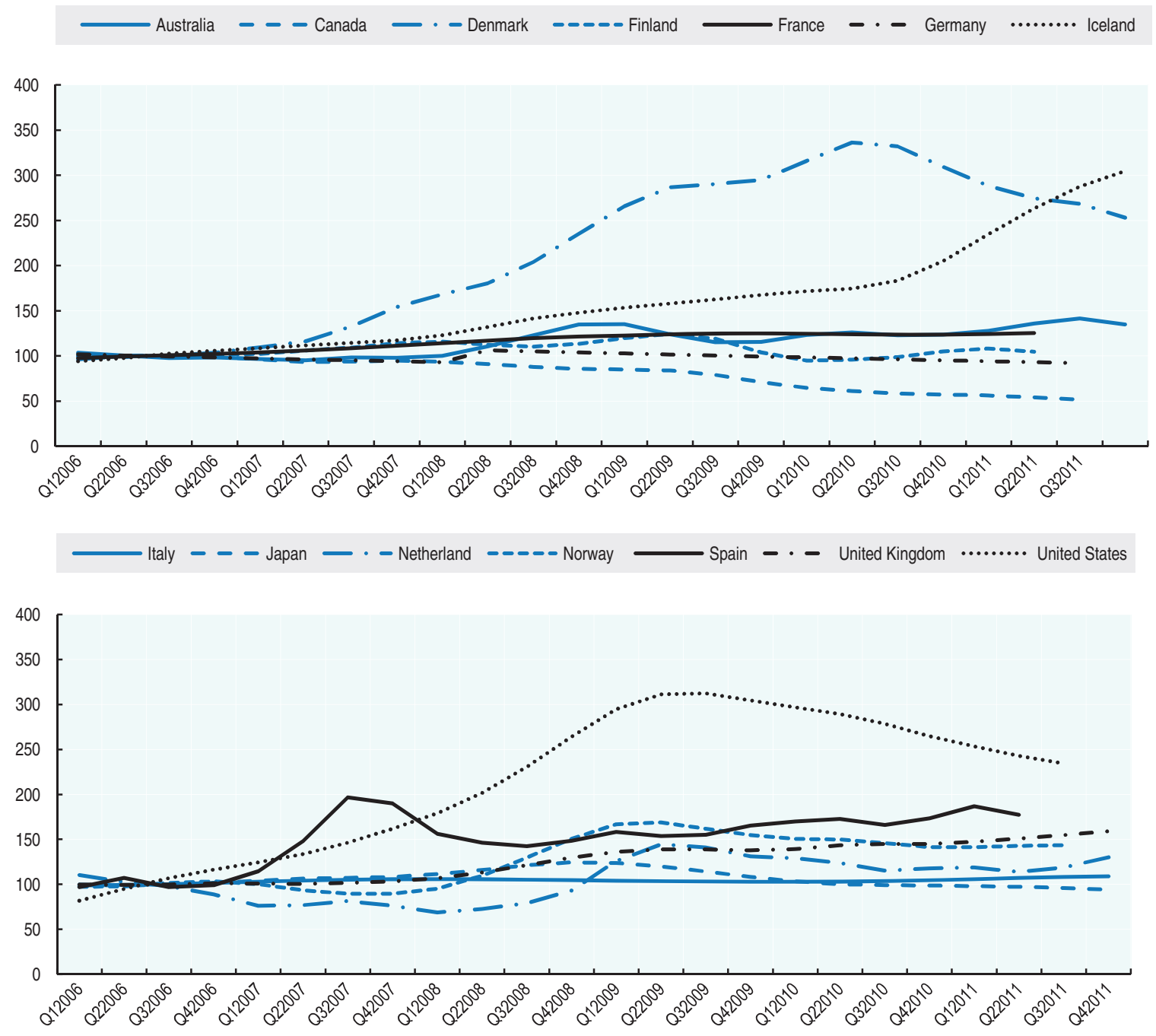

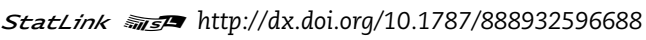

\section{Definitions and methodology}

The global crisis heightened interest in entrepreneurship as an essential element to foster economic recovery and employment growth. In order to analyse the impacts of economic cycles on new firm creation, policy makers and analysts need as recent data as possible. The OECD "timely indicators of entrepreneurship" respond to this need and are the result of a new data collection process. They are designed to complement the harmonised business demography indicators from the OECD Structural and Demographic Business Statistics (SDBS) database. Their main purpose is to provide timely information, although this involves limitations in terms of cross-country comparability.

The Timely Indicators of Entrepreneurship (TIE) database uses data based on national definitions only. When possible, adjustments are made to get as close as possible to the Eurostat-OECD Manual on Business Demography Statistics standard definitions (for example by removing agriculture and public companies, excluding inactive companies, etc.). However, since a single source is used, rather than the multiple sources used for 
national business registers, the population of enterprises is often incomplete. Depending on the country, the chosen single source may not cover certain legal forms of enterprises (e.g. sole proprietor) or sectors of activity (e.g. education) or enterprises below a certain turnover or employment threshold.

In the timely indicators database:

- An enterprise creation refers to the emergence of a new production unit. This can be either due to a real birth of the unit, or the result of a merger, break-up, split-off or reactivation.

- Bankruptcy is used as an indicator for enterprise deaths.

The concepts of enterprise "creation" and "failure" reflected in the data series differ across countries. Some of the national sources selected for the timely indicators use the concept of enterprise birth, while others use the broader concept of enterprise creation. The concept of enterprise birth is more restrictive than the concept of creation as it refers to a legal entity that appears for the first time with no other enterprise involved in the creation process. It excludes firm creations resulting from mergers or changes of name, type of activity or ownership.

Also, bankruptcy laws differ across countries. In some countries a declaration of bankruptcy means that the enterprise must stop trading immediately. In other countries, enterprises can declare themselves as bankrupt but can still continue trading with receivers in operational control. This results in the winding-up of the enterprise as it goes into liquidation but sometimes the enterprise is able to continue operating, albeit with more restrictive operations and under new management. This means that some enterprises on business registers may be active but also bankrupt, making it very difficult to use a concept of deaths based on bankruptcy, particularly as some nominally bankrupt companies may recover.

On the other hand, firm closures can be due to different reasons, and only some consist of liquidations following bankruptcy. The financial literature has highlighted that countries differ in terms of the probabilities of firms being involved in bankruptcy or other insolvency procedures, and also in the final results of these procedures. The proportion of bankruptcy procedures that end up in actual liquidations of the companies, and not in reorganisations, varies across countries depending on the bankruptcy code.

Finally, the timely indicators of entrepreneurship are meant to be used for comparisons across countries in terms of trends and are presented as trend-cycle data. The trend-cycle is the underlying path or general direction reflected in data over the longer term, i.e. the combined long-term (trend) and medium-to-long-term (cycle) movements in the original series. In a time series, the trend-cycle is the component that represents variations of low frequency, the high frequency fluctuations having been filtered out. This component can be viewed as those variations with a period longer than a chosen threshold (usually $11 / 2$ years is considered as the minimum length of the business cycle). In practice, the estimation of the trend-cycle is done by estimating and removing the seasonal and irregular components from the original non-adjusted data.

\section{Sources of data on new creations and bankruptcies}

The OECD Timely Indicators of Entrepreneurship database is available on http:// dotstat.oecd.org/Index.aspx. Sources and definitions for enterprise entries and bankruptcies used in the database are described in Tables 0.1 and 0.2 respectively. 


\section{Table 0.1. National sources and definitions of enterprise creations}

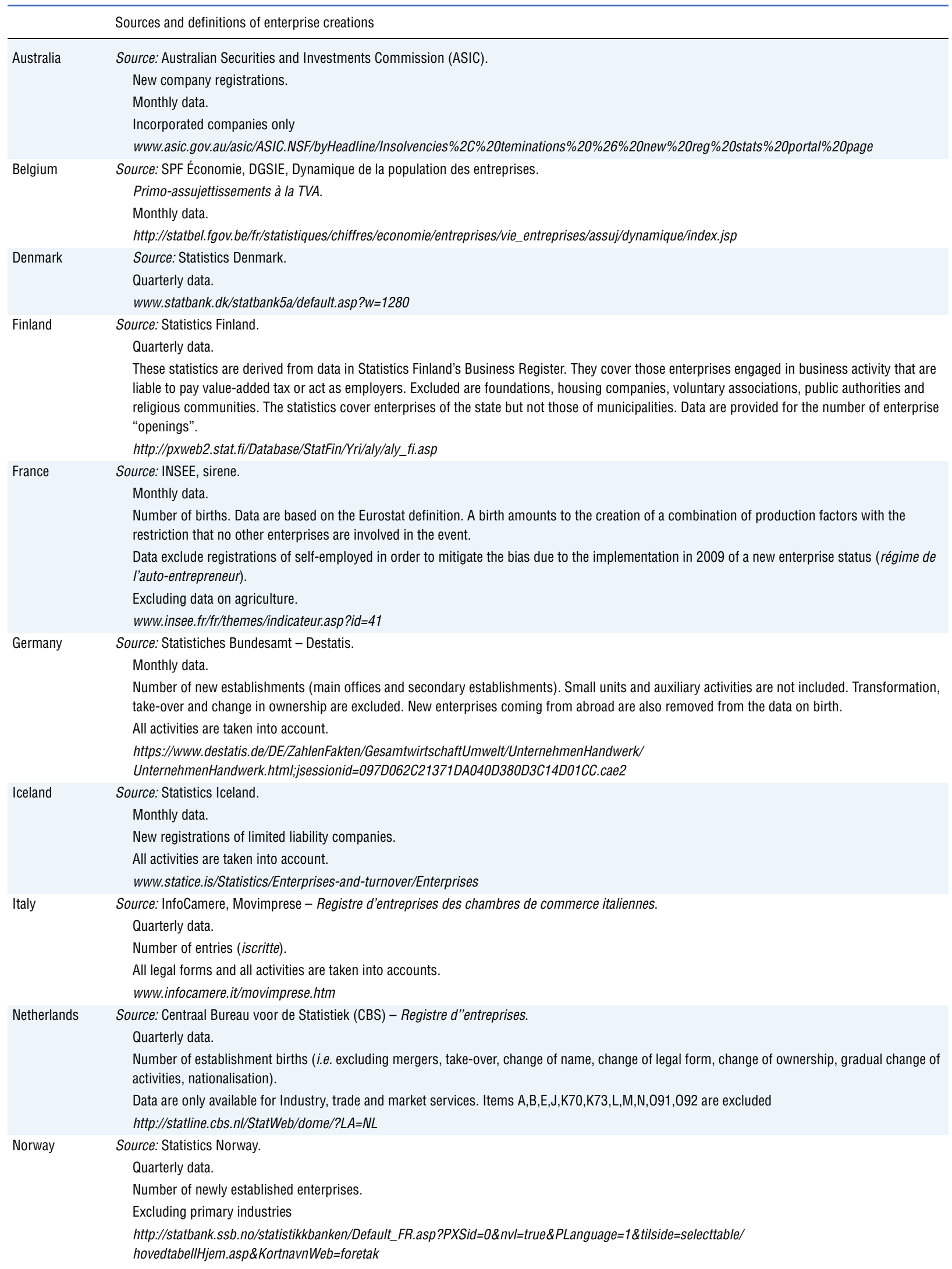




\section{Table 0.1. National sources and definitions of enterprise creations (cont.)}

\begin{tabular}{|c|c|}
\hline & Sources and definitions of enterprise creations \\
\hline \multirow[t]{5}{*}{ Spain } & Source: Instituto Nacional de Estadistica de Espana (INE). \\
\hline & The Mercantile Companies (MC) for monthly data. \\
\hline & Number of entries. \\
\hline & $\begin{array}{l}\text { The "Mercantile Companies" register includes information on incorporated enterprises (natural persons or sole proprietors are excluded). Created } \\
\text { "mercantile companies" may not be active and "dissolved mercantile companies" might be removed from the register without having ever been } \\
\text { active. }\end{array}$ \\
\hline & www.ine.es/jaxi/menu.do?type=pcaxis\&path=\%2Ft30\%2Fp151\&file=inebase \&L=1 \\
\hline \multirow[t]{4}{*}{ Sweden } & Source: Swedish Agency for Growth Analysis. \\
\hline & Quarterly data. \\
\hline & Number of new enterprises (genuine new businesses, i.e. births). \\
\hline & www.tillvaxtanalys.se/sv/statistik/ \\
\hline \multirow[t]{6}{*}{ United Kingdom } & Source: Companies House. \\
\hline & Monthly data. \\
\hline & New registrations (number of entries). \\
\hline & All limited companies in England, Wales, Northern Ireland and Scotland are registered at Companies House. \\
\hline & $\begin{array}{l}\text { Entries reflect the appearance of a new enterprise within the economy, whatever the demographic event, be that a merger, renaming, split-off... or } \\
\text { birth. }\end{array}$ \\
\hline & www.companieshouse.gov.uk/about/businessRegisterStat.shtmI \\
\hline \multirow[t]{4}{*}{ United States } & Source: Bureau of Labor Statistics (BLS) - Business Employment Dynamics (BED). \\
\hline & Quarterly data. \\
\hline & Number of establishments with at least one employee. \\
\hline & www.bls.gov/bdm/ \\
\hline
\end{tabular}

\section{Table 0.2. National sources and definitions of bankruptcies}

\begin{tabular}{|c|c|}
\hline Countries & Sources and definitions of bankruptcies \\
\hline \multirow[t]{6}{*}{ Australia } & Source: Australian Securities and Investments Commission (ASIC). \\
\hline & Monthly data. \\
\hline & Insolvency statistics - Companies entering external administration. \\
\hline & $\begin{array}{l}\text { The statistics on "Companies entering external administration" show the number of companies entering into a form of external administration for the } \\
\text { first time. ASIC advises that a company will be included only once in these statistics, regardless of whether it subsequently enters into another form of } \\
\text { external administration. The only exception occurs where a company is taken out of external administration, for example as the result of a court order, } \\
\text { and at a later date re-enters external administration. Members voluntary windings up are excluded. }\end{array}$ \\
\hline & May include provisional data. \\
\hline & www.asic.gov.au/asic/ASIC.NSF/byHeadline/Insolvencies,\%20teminations\%20\&\%20new\%20reg\%20stats\%20portal\%20page \\
\hline \multirow[t]{4}{*}{ Canada } & Source: Office of the Superintendent of Bankruptcy Canada. \\
\hline & Monthly data. \\
\hline & $\begin{array}{l}\text { A business bankruptcy is defined as the state of a business that has made an assignment in bankruptcy or against whom a bankruptcy order has been } \\
\text { made. A business is defined as any commercial entity or organisation other than an individual, or an individual who has incurred } 50 \text { percent or more of } \\
\text { total liabilities as a result of operating a business. }\end{array}$ \\
\hline & http://osb.ic.gc.ca \\
\hline \multirow[t]{3}{*}{ Denmark } & Source Statistics Denmark. \\
\hline & $\begin{array}{l}\text { Registry-based method from January } 2009 \text { onwards, "simple count" method before. The number of announcements of bankruptcies is counted } \\
\text { excluding units from the Faroe Islands and Greenland. When using the "simple count method", bankruptcies of both enterprises and individuals } \\
\text { (personal bankruptcies) were counted. After the implementation of the registry-based method, only bankruptcies of enterprises are counted, i.e. } \\
\text { bankruptcies associated with a "CVR"-number. }\end{array}$ \\
\hline & www.statbank.dk/statbank5a/default.asp?w=1280 \\
\hline \multirow[t]{4}{*}{ Finland } & Source: Statistics Finland. \\
\hline & Quarterly data. \\
\hline & $\begin{array}{l}\text { They cover those enterprises engaged in business activity that are liable to pay value-added tax or act as employers. Excluded are foundations, housing } \\
\text { companies, voluntary associations, public authorities and religious communities. The statistics cover enterprises of the state but not those of } \\
\text { municipalities. }\end{array}$ \\
\hline & http://pxweb2.stat.fi/Database/StatFin/Yri/aly/aly_fi.asp \\
\hline
\end{tabular}




\section{Table 0.2. National sources and definitions of bankruptcies (cont.)}

\begin{tabular}{|c|c|}
\hline Countries & Sources and definitions of bankruptcies \\
\hline \multirow[t]{5}{*}{ France } & Source: BODACC (bulletin officiel d'annonces civiles et commerciales) data processed by INSEE. \\
\hline & Monthly data. \\
\hline & Business failures. \\
\hline & $\begin{array}{l}\text { A business failure is defined as the opening of insolvency proceedings. The statistics on business failures cover both the opening of insolvency } \\
\text { proceedings and direct liquidations. They do not reflect the outcome of the proceedings: continuation, take-over or liquidation. }\end{array}$ \\
\hline & www.insee.fr/en/themes/indicateur.asp?id=71 \\
\hline \multirow[t]{5}{*}{ Germany } & Source: Statistiches Bundesamt - Destatis - Unternehmen und Arbeitsstätten, Gewerbeanzeigen. \\
\hline & Monthly data. \\
\hline & $\begin{array}{l}\text { Statistics are based on business registers. Small units and auxiliary activities are not included. Transformation, take-over and change in ownership are } \\
\text { excluded. All activities are taken into account. }\end{array}$ \\
\hline & https://www.destatis.de/DE/ZahlenFakten/GesamtwirtschaftUmwelt/UnternehmenHandwerk/UnternehmenHandwerk.html;jsessionid= \\
\hline & 097D062C21371DA040D380D3C14D01CC.cae2 \\
\hline \multirow[t]{4}{*}{ Iceland } & Source: Statistics Iceland. \\
\hline & Monthly data. \\
\hline & Insolvencies of Icelandic enterprises by field of activity, including personal. \\
\hline & www.statice.is/Statistics/Enterprises-and-turnover/Enterprises \\
\hline \multirow[t]{5}{*}{ Italy } & Source: InfoCamere, Movimprese - Registre d"entreprises des chambres de commerce italiennes. \\
\hline & Quarterly data. \\
\hline & Number of exits (cessate). \\
\hline & All legal forms and all activities are taken into account. \\
\hline & www.infocamere.it/movimprese.htm \\
\hline \multirow[t]{6}{*}{ Japan } & Source: Japan Small Business Research Institute (JSBRI) \\
\hline & Monthly data. \\
\hline & Number of Bankruptcies. \\
\hline & $\begin{array}{l}\text { Those statistics compiled by the JSBRI are from the Ministry of Economy, Trade and Industry Small and Medium Enterprise Agency Business } \\
\text { Environment Department Planning Division Research Office. }\end{array}$ \\
\hline & $\begin{array}{l}\text { Bankruptcies are counted for companies where "bankruptcy" represents more than USD } 10 \text { million of the total liabilities. Are included under the } \\
\text { definition of "bankruptcy": default on due payments, legal and corporate reorganisation, company organised by the Commercial Code of Composition } \\
\text { Act, hasan,-special liquidation. However, closed, out of business, dissolution, personnel cutbacks, such as cases jump bail are excluded. }\end{array}$ \\
\hline & www.jsbri.or.jp/new-hp/statistics/s1.html\#s1-4 \\
\hline \multirow[t]{5}{*}{ Netherlands } & Source: Centraal Bureau voor de Statistiek (CBS) - \\
\hline & Quarterly data. \\
\hline & Number of bankruptcies pronounced by Dutch courts. \\
\hline & Excluding individuals without a sole proprietorship. \\
\hline & www.cbs.nl/en-GB/menu/themas/bedrijven/cijfers/default.htm?Languageswitch=on \\
\hline \multirow[t]{5}{*}{ Spain } & Source: Instituto Nacional de Estadistica de Espana (INE) - \\
\hline & The Mercantile Companies (MC). For Monthly data. \\
\hline & Number of exits. \\
\hline & $\begin{array}{l}\text { The "Mercantile Companies" register includes information on incorporated enterprises (natural persons or sole proprietors are excluded). "Created } \\
\text { mercantile companies" may not be active and "dissolved mercantile companies" might be removed from the register without having ever been active }\end{array}$ \\
\hline & www.ine.es/jaxi/menu.do?type=pcaxis\&path=\%2Ft30\%2Fp151\&file=inebase \&L=1 \\
\hline \multirow[t]{5}{*}{ United Kingdom } & Source: Companies House. \\
\hline & Monthly data. \\
\hline & Incorporated companies only. \\
\hline & $\begin{array}{l}\text { Total insolvencies. Including compulsory liquidations, creditors' voluntary liquidations, and administrative orders converted to Cred. Excluding } \\
\text { Members' voluntary liquidations. }\end{array}$ \\
\hline & www.companieshouse.gov.uk/about/companiesRegActivities.shtml \\
\hline \multirow[t]{4}{*}{ United States } & Source:United States Courts. \\
\hline & Quarterly data. \\
\hline & Statistics on bankruptcy petition filings - total business filings (Chapters 7,11 and 13 ). \\
\hline & www.uscourts.gov/Statistics/BankruptcyStatistics.aspx \\
\hline
\end{tabular}



PART I

\section{Measuring Entrepreneurship}



PART I

Chapter 1

\section{Measuring Women Entrepreneurship}


W omen are one of the most relevant untapped resources for entrepreneurship. Very little is known about the economic relevance of women's entrepreneurship, about the policy instruments that are effective in raising entrepreneurship rates among women, and about the economy-wide effects of higher participation of women in entrepreneurial activity. The policy rationale for the development of women's entrepreneurship was traditionally focused on women's equality and empowerment, and social inclusion (Lotti, 2006). Only in the more recent years, it has become clear that women entrepreneurs create new jobs for themselves and others and "[...] can provide society with different perspectives and approaches to management, organisation and business issues" (OECD, 2004).

This chapter presents definitions, data sources and methods for developing international statistics on women's entrepreneurship. Chapter 7 in this publication presents the first results from an original data collection based on this methodological chapter. This work is undertaken within the framework of the OECD Gender Initiative, a high-profile, horizontal activity that involves many OECD Committees and Directorates. The Initiative analyses gender equality in employment, education and entrepreneurship in OECD countries, as well as in emerging and developing economies. The data development discussed in this chapter and in Chapter 7 are analysed in the OECD Report "Gender Equality in Education, Employment and Entrepreneurship: Final Report to the Ministerial Council Meeting 2012". They also contribute to a data portal on gender statistics to be launched by the OECD in 2012. These statistics should provide a solid knowledge base for policy making, until now relying mostly on anecdotal evidence and country-specific studies. The overall goal is to quantify the gender-gap in entrepreneurship along its many dimensions, and to search for relevant explanations of this gap through cross-country comparative analysis.

The development of international data on gender differences in entrepreneurship can rely on the methodologies developed for the OECD/EUROSTAT Entrepreneurship Indicator Programme (EIP). In line with the principles guiding the EIP, this note focuses attention on ways to better exploit and internationally harmonise existing firm-level data available on a yearly basis, business registers above all. Given the difficulties of producing gender disaggregated statistics from business registers in several countries, an investment in the production of indicators on women and men entrepreneurs from population-based data sources (surveys of the labour force) is also suggested. In the longer run, an effort towards the international harmonisation of surveys of entrepreneurs and their enterprises is needed to learn more about motivations behind women and men's choices to start a business, their management strategies, and the constraints and difficulties they face.

\subsection{Defining the entrepreneur: Conceptual and measurement issues}

The first condition for sound analysis of gender differentials in entrepreneurship is a solid identification of the population of interest. There are two related issues to address: 
i) how to distinguish entrepreneurs from other economic agents; ii) how to distinguish women and men enterprises. Neither issues are trivial. The word "entrepreneur" is in fact commonly used to describe very different economic agents, such as the founder of a startup, a member of the directing board of a company, a self-employed person in a inherited business, an innovating manager, etc. There is a large and interdisciplinary literature that tries to determine who entrepreneurs are and why they choose to start-up a business (Blanchflower and Oswald, 1998; Djankov et al. 2005). As summarised by Langlois (2007), different schools have seen the entrepreneurs as a "discoverer", always alert to new opportunities (Kirzner); as an "evaluator", with the faculty of judgment in economic organisation; and as an "exploiter" of new opportunities, carrying out new combinations and the creative destruction that results there from (Schumpeter). A general finding in the empirical literature is that entrepreneurs have peculiar characteristics. They are less riskaverse compared to other people (Kihlstrom and Laffont, 1979), have the ability to perform many different tasks (they are "jack of all trades" according to Lazear, 2005), and can rely by inheritance or through their personal efforts on strong and effective social networks (Djankov et al. 2005).

The EIP has proposed the following conceptual definition of entrepreneurs:

Entrepreneurs are those persons (business owners) who seek to generate value, through the creation or expansion of economic activity, by identifying and exploiting new products, processes or markets.

Enterprising human activity, value creation, and novelty (innovation) are thus the three essential requirements of an entrepreneur as defined by the EIP framework (Ahmad and Hoffman, 2008). The strength of this definition is that entrepreneurs are identified not only by their actions and by how they perceive their own work, but also by the outcomes of their activities. They need to make a personal investment (in terms of time, ideas and resources) to put in place an activity involving a degree of risk and uncertainty. The outcome of this activity needs to be "novel", i.e. characterised by a clear discontinuity with respect to what already existed before the entrepreneur's investment. Finally, the innovation embodied in the activity needs to generate economic and/or social value to the public.

The EIP conceptual definition helps eliminating several elements of ambiguity, related to size thresholds for the enterprises to be considered, and the requirement of ownership or shareholding. In particular:

i) Size issue. Entrepreneurs and entrepreneurship are not concepts that relate exclusively to small and medium-sized enterprises (SMEs). Large enterprises can also be entrepreneurial, and their performance can be directly related to the activity of identifiable physical persons. Things get more complex at the other end of the spectrum. In fact, one might wonder whether the requirements of "novelty" and "creation of value" imply by necessity a minimum size for the enterprise, i.e. if we need to consider as entrepreneurs only those who employ at least one other person. International comparability reasons related to the coverage of business registers might require that the relevant universe be restricted to employer enterprises. On one hand, the restriction to employer entrepreneurs would allow excluding a large number of "casual businesses", owned by wage and salary workers to complement their earnings (Fairlie and Robb, 2009). On the other hand, it is increasingly possible to develop an entrepreneurial activity (an activity characterised by risk taking, novelty and 
generating value) without employing others, especially during the early stage of the business. If women or other categories of interest are over-represented among nonemployer entrepreneurs, then limiting the observation to businesses with employees would yield a biased picture of reality. It is proposed that an explicit distinction be made between employer and non-employer entrepreneurs, and that distinct data are collected for the two whenever possible.

ii) Requirement of ownership or shareholding. The EIP definition makes clear that entrepreneurs are business owners, bearing the risk associated with the activity of enterprise. Managers with no share-holding are not considered entrepreneurs even if they have delegated control over key financial and investment decisions.

The EIP conceptual definition of entrepreneurs needs to be translated into an operational definition, in order to guide measurement and statistical comparisons. This translation presents some obvious difficulties, given that the characteristics of the entrepreneurs and of their activity underlined by the EIP definition are very hard to measure given available data. Information on characteristics of business owners is typically scarce in information collected at the level of the establishment or the enterprise. Similarly, relevant information on the business activity is not available in household and labor force data, which instead provide details on the individual business owners.

The operational definition of entrepreneurs suggested herewith is the following:

Entrepreneurs are persons that have a direct control over the activities of an enterprise, by owning the totality or a significant share of the business. Employer entrepreneurs are those entrepreneurs who employ at least one other person.

The measurement agenda of the EIP has focused over the last years on the production of new and internationally comparable information from business registers. Is it possible to incorporate a gender dimension in this agenda? In other words, is it possible to identify women and men-owned enterprises using business register data, so as to develop genderdisaggregated, yearly measures of enterprise performance that are comparable across countries?

In enterprises with only one owner, the entrepreneur can be simply identified as the sole-proprietor. Those enterprises with a sole-proprietor woman at a given time can be defined as "women-owned enterprises", consistently with the operational definition above. It is important to note that while in some countries sole-proprietorship is a general term covering all the businesses owned by one individual, in other countries (e.g. in the United States) sole-proprietorship is a specific legal status associated to enterprises with unlimited personal liability and subjected to a particular tax regime.

The statistical identification of the entrepreneur in enterprises with legal forms other than sole-proprietorship requires the establishment of rules defining a significant share of ownership. According to the operational definition, significant means high enough to grant influence and control over the key strategic decisions concerning the functioning and the development of the business. In the contexts of partnerships and corporations, the ownership of a minimum percentage (e.g. $25 \%$ ) of the equity, interest, or stock of the business might be required. Given limited data availability on ownership shares, more discussion is needed to agree on the statistical identification of (not sole-proprietor) entrepreneurs for international data harmonisation. 


\subsection{Measurement issues, data and options for the development of gender indicators}

To develop gender indicators of entrepreneurship, two different sources of existing data are relevant: i) data from labour force surveys and population censuses, and ii) firmlevel data from registers, surveys and economic censuses with information on the business owners. As they refer to two different statistical populations, these two data sources are likely to yield significantly different results when used to produce the same indicator. They are, however, highly complementary.

\section{Gender indicators of entrepreneurship from labour force surveys and population censuses}

Self-employment is the most widely used measure of business ownership and entrepreneurial activity. It is generally estimated on a yearly basis through labour force surveys. The International Labour Organization (ILO) framework for the labour force surveys has enhanced international harmonisation in data collection. However, international comparability problems still exist, also for the figures on self-employment. They mainly have to do with the treatment of incorporated self-employed (owner/managers of incorporated businesses). In some countries these are counted as self-employed while in other countries they are counted as employees (Van Stel, 2004; and Fairlie and Robb, 2009). Moreover, not all the countries producing statistics on self-employment follow the ILO guidelines.

The most relevant shortcoming when equating entrepreneurs with the self-employed is the very broad meaning of self-employment, and consequently the heterogeneity of actors that are assigned to this category. In fact, counts of the self-employed generally include many "types" of workers, such as taxi drivers, baby-sitters, etc. who are closer in terms of activities and profile to employees rather than to entrepreneurs. Another issue is that self-employment is generally self-assessed, i.e. people are counted as self-employed if they say that they are. This implies that it is easy to find in these counts, for example, consultants who work for an agency, but do not perceive themselves as employees of the agency. Finally, it is not straightforward to make inferences on the number of enterprises from statistics on self-employment, given that single enterprises might be co-owned by several self-employed, and that many entrepreneurs might not be counted as selfemployed if they have another primary occupation.

In order to reduce the heterogeneity of the professional figures counted under the category of "self-employed", one possibility would be to focus on the sub-category of selfemployed with employees ("employers"). Employers are more likely to be individuals who work on an entrepreneurial project they can expand or change as market opportunities emerge. Moreover, gender differences are generally more marked when focusing on employers. The number of men and women employers has remained fairly stable over the last decade in European countries (Figure 1.1). There has been a moderate increase in the number of both women and men own-account workers in Europe. Interestingly, while the number of men working on own-account is about double the number of women, men employers are more than three times the number of women employers. In the United States, the fraction of self-employed who have paid employees is lower among women than among men. Differences in the gender composition of employers and own-account workers tend to be more pronounced in emerging and developing countries (Peña Parga and Mondragon-Vélez, 2009). 
Figure 1.1. Trends in employers and own account workers

Thousands

Europe 27

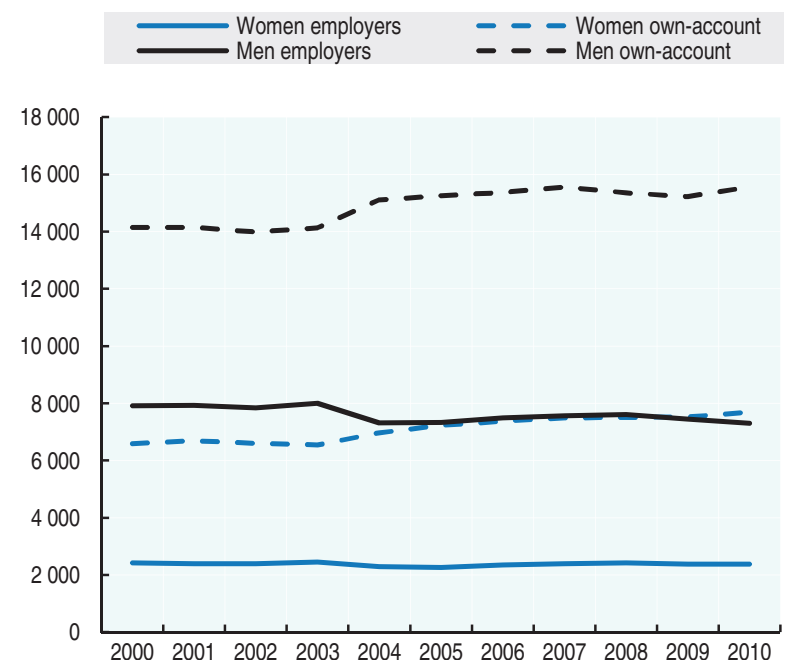

United States
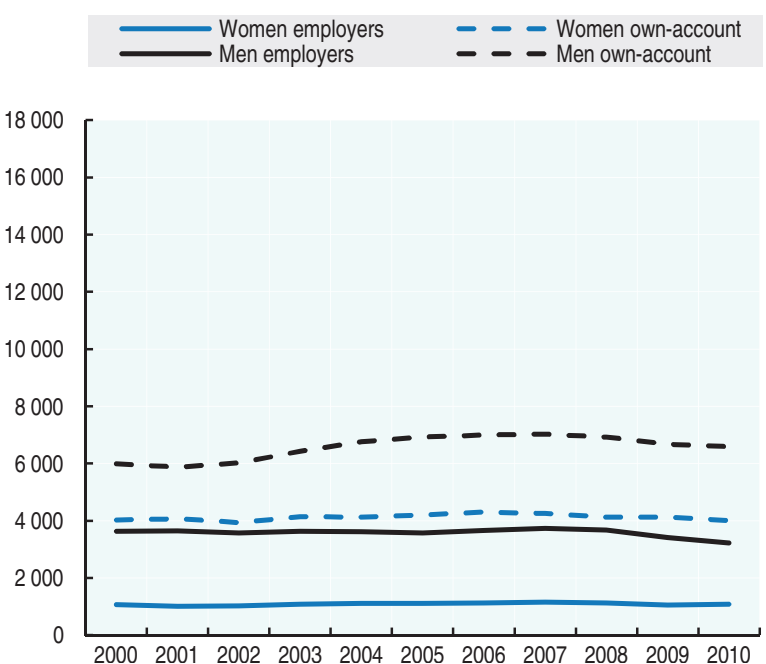

Source: Eurostat Labour Force Survey, 2000-10 for European Countries, and Current Population Survey annual averages for outgoing rotation groups for the United States (estimated numbers in thousands). For the United States, data include both incorporated and unincorporated self-employed. The number of incorporated self-employed with and without employees has been estimated on the basis of data from the Contingent and Alternative Work Arrangements Surveys.

The main issue with the development of distinct indicators for employers and ownaccount workers is the limited number of self-employed women and men with employees in the surveys' samples. When this small number is disaggregated according to some characteristics of the women employers (to study, for example, the distribution of women employers across industries), there is a serious risk of obtaining figures that are below the thresholds applied by countries for ensuring the statistical reliability of the estimates. This is particularly the case for labour force surveys with relatively small samples and for surveys which do not classify incorporated business owners as self-employed. The percentage of women with paid employees among the unincorporated self-employed is generally low (only $8.9 \%$ of the unincorporated self-employed women in the United States had paid employees in 2009 (Hipple, 2010)). While conceptually it makes sense to develop distinct indicators for employers and for own-account workers, concerns about the statistical reliability of the survey estimates suggest aggregating all the self-employed (with and without employees) into one single category.

Using labour force surveys (LFS) from OECD and non-OECD countries, it is possible to build comparable indicators on trends in the distribution of self-employed men and women by size of their firms (number of employees) and by industry sectors. Moreover, the questionnaires of the labour force surveys generally include information on the 1) tenure in the activity, 2) age, 3) share of foreign-born, 4) education level, 5) hours worked, 6) investments in training, for self-employed men and women. Covering the whole population in working age, LFS enable relevant cross-country comparisons of the selfemployed with those working for a salary.

One limitation of LFS data as a source of information on entrepreneurs is that they rarely include questions about motivations for a particular career choice, about satisfaction in the current job or about problems faced in the current occupation. It is thus hard to 
conclude, from labour force surveys, whether the lower propensity of women to work as a business owner is due to lower preferences ("motivations") of women for an entrepreneurial career. Limited evidence on preferences for self-employment can be produced by looking at job-transitions of men and women, or at the type of employment sought for by the currently unemployed. ${ }^{1}$

A further limitation is that it is still not feasible to provide international figures on earnings from self-employment from most of the available labour force survey data. Other household surveys with detailed modules on earnings, assets and wealth, are more suited than LFS to assess the relative returns from entrepreneurial activity for women and men. Figure 1.2 uses data from different household surveys with detailed earning modules. It shows that profits (or losses) net of taxes from self-employment tend to be significantly lower for women. The derivation of a good measure of returns from self-employment activities is highly complex, and further harmonisation in household surveys is needed before this crucial piece of information can be made available and comparable for all OECD countries. $^{2}$

Figure 1.2. Median earnings gap of self-employed women and men, 2008

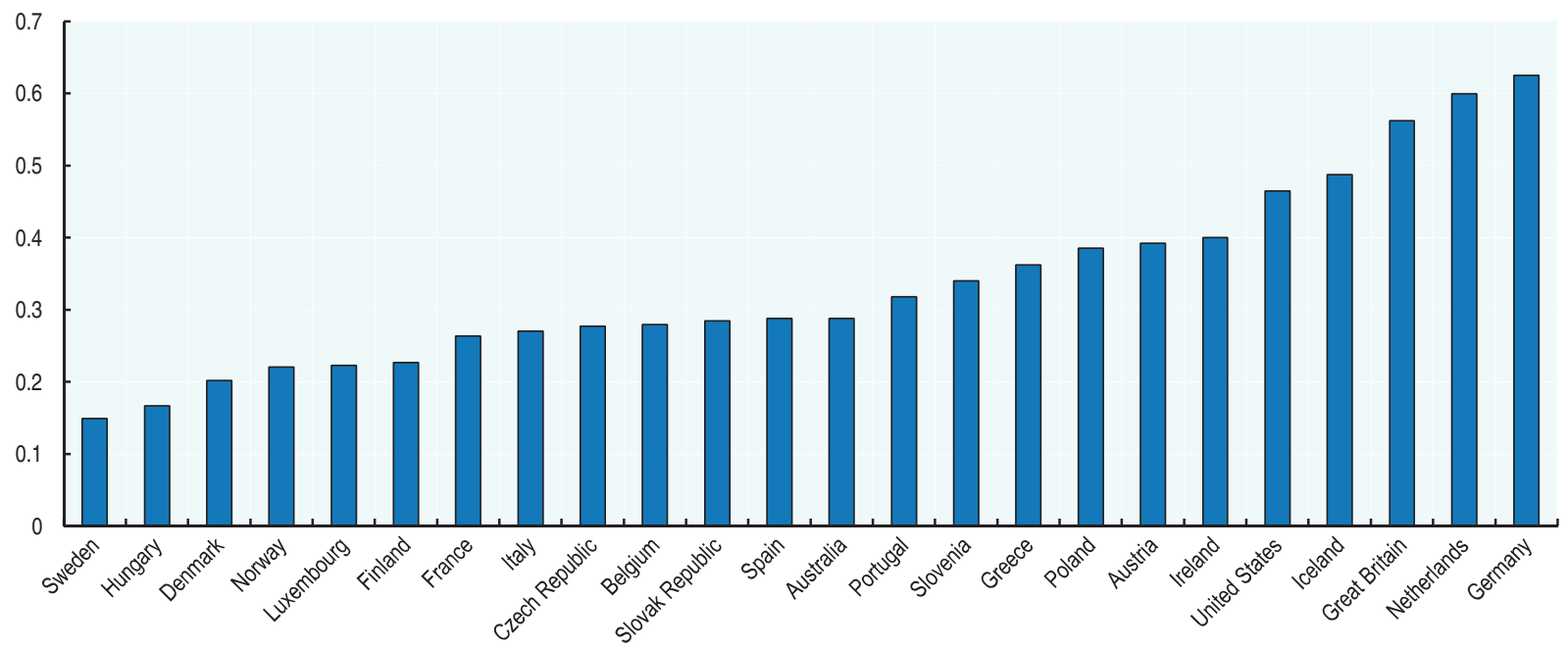

Source: Estimates from European Union Statistics on Income and Living Conditions (EU-SILC), 2008 wave Survey of Income and Program Participation 2008 for United States, Household, Income and Labour Dynamics in Australia (HILDA) 2008 wave.

Statistics on the self-employed from population surveys or censuses are relevant for comparative analysis of trends in entrepreneurial activity, given their information content and their wide cross-country availability. However, they can only be of limited use to assess how owner characteristics relate to enterprise performance. Significant progress in this direction can only be achieved through novel use and extensions of firm-level statistics.

\section{Gender indicators of entrepreneurship from firm-level data sources}

\section{Comparing women and men enterprises using business registers and economic censuses}

Business registers linked with administrative sources on individuals (population registers or tax records) and representative business survey data are more suited than population surveys to the analysis of how heterogeneous outcomes of the firms relate to characteristics of 
their owners. The range of individual characteristics that are recorded in these linked registers varies a lot across countries, but it is generally possible to obtain information about the gender of at least the primary enterprise owner. The coverage and availability on a yearly basis of business registers make them an essential resource for the comparative analysis of dynamics in women and men-owned enterprises. Countries using economic censuses instead of registers can generally monitor changes over five years in the number, size, industry, employment and financial variables for establishments owned by men and by women.

There are two main issues related to the use of business registers for cross-country, comparative analysis of women and men enterprises. The first is the difficulty of producing, in several countries, even basic business statistics with a breakdown by characteristics of the owners. Besides countries in Northern Europe, exercises in linking business and individual registers have been undertaken in Austria, Italy, New Zealand, Portugal, Spain and the United States. The second issue is the difficulty of assigning a 'gender' to enterprises with other legal forms than sole-proprietorship. When there is more than an individual owner, additional information is needed in order to assess whether women or men are responsible for the enterprise and control its activities. Data on the shares of the business stocks, assets or interests owned by the different individuals can enable the identification of men-owned enterprises (enterprises where one or more men control more than $50 \%$ of the shares), women-owned enterprises (enterprises where one or more women control more than $50 \%$ of the shares) and enterprises with mixed ownership. ${ }^{3}$ Unfortunately, data on shareholdings are rarely integrated into business registers. An alternative to shareholding data is represented by the linkage of business registers with tax data. The main owners of the enterprise can be identified by comparing the levels of declared revenues of the different individuals participating in the business.

A first data collection is ongoing within the EIP programme to assess the feasibility of building comparable indicators of business demography for individual (sole-proprietor) enterprises, using data from business registers. ${ }^{4}$ Statistics are being collected by gender of the sole-proprietor for the following indicators: i) number; ii) number of persons employed; iii) turnover; iv) birth rates; v) death rates; vi) three-year survival rates; vii) employment growth in surviving enterprises. Consistently with the other EIP data collections, the indicators are calculated for employer enterprises, i.e. enterprises with at least one employee. The definitions of the indicators are derived from the OECD/Eurostat Manual on Enterprise Business Demography. The result from this data collection would provide the first international statistics on the number, economic weight and sectoral distribution of women and menowned enterprises from official business statistics. Cross-country comparisons based on these data might also provide relevant insights on the dynamics of women's entrepreneurship, as captured by birth, death and survival rates. In Austria for example, women represent a minority of active sole-proprietor enterprises in 2009, but the birth rate of women-owned enterprises has also been relatively higher (Figure 1.3). Importantly, the death rate of womenowned enterprises has also been higher compared to that of men-owned enterprises.

The international comparability of these indicators crucially depends on the consistency of the definition of "sole-proprietorship" across countries. As mentioned, in some countries sole-proprietorship is a general term covering all the businesses owned by one individual, while in other countries (e.g. in the United States) sole-proprietorship is a specific legal status associated to enterprises with unlimited personal liability and subjected to a particular tax regime. If there are specific incentives to register one's enterprise as a soleproprietorship, and these incentives vary across countries, then international comparability 
Figure 1.3. Austria: Births, birth and death rates of sole-proprietor enterprises by gender of owner, 2009

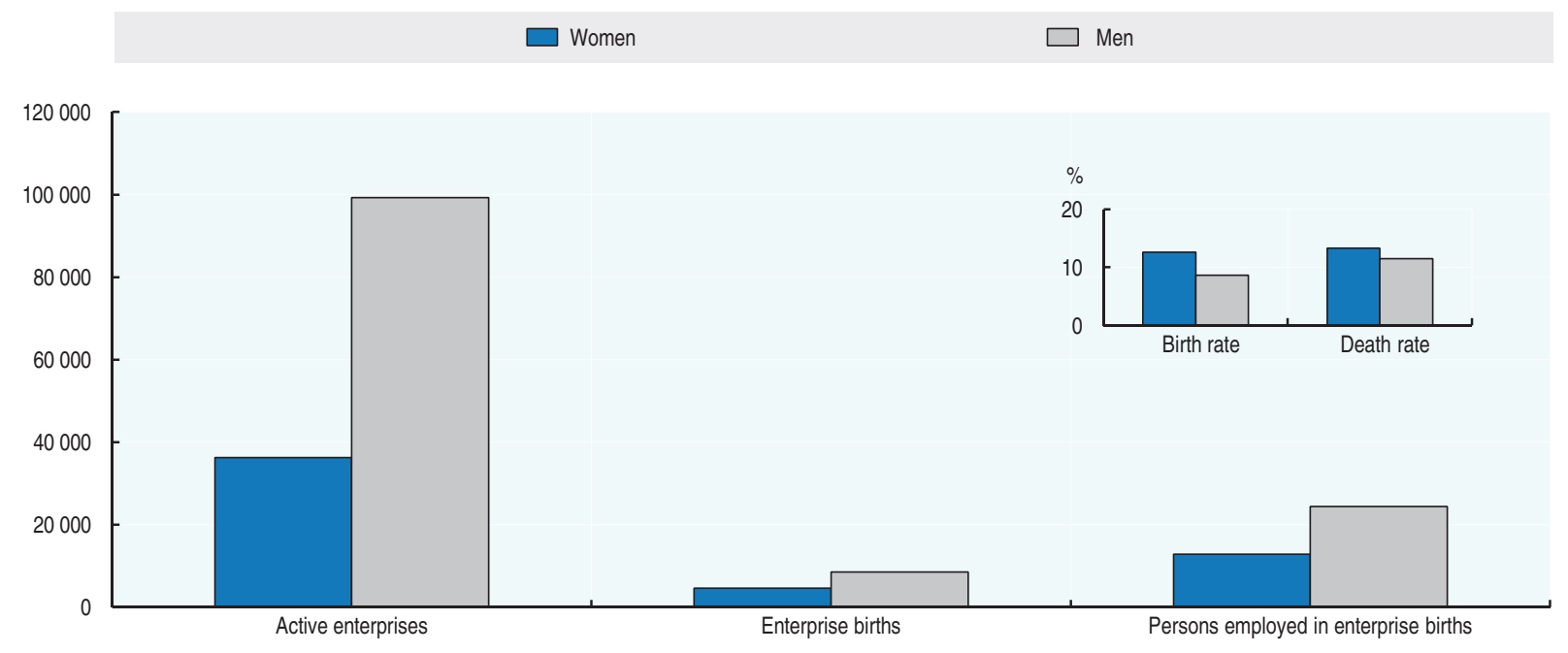

Source: Selected Statistics from Statistics Austria Employer Enterprise Demography.

might be hampered. Moreover, the difference by gender observed for sole-proprietor enterprises might be more or less marked when the focus shifts to other legal forms of enterprises. Current OECD work is assessing these differences across countries by comparing the legal regimes, the relative presence of sole-proprietorships across countries, as well as the presence of women in enterprises of different legal forms in a sample of countries with available data. In Norway, for instance, sole proprietorship is much more prevalent than partnership, and the distribution of women owners across three different legal types of enterprises is fairly homogenous (Figure 1.4).

Figure 1.4. Norway: Enterprises by ownership type and gender of owner, 2010

Number and share

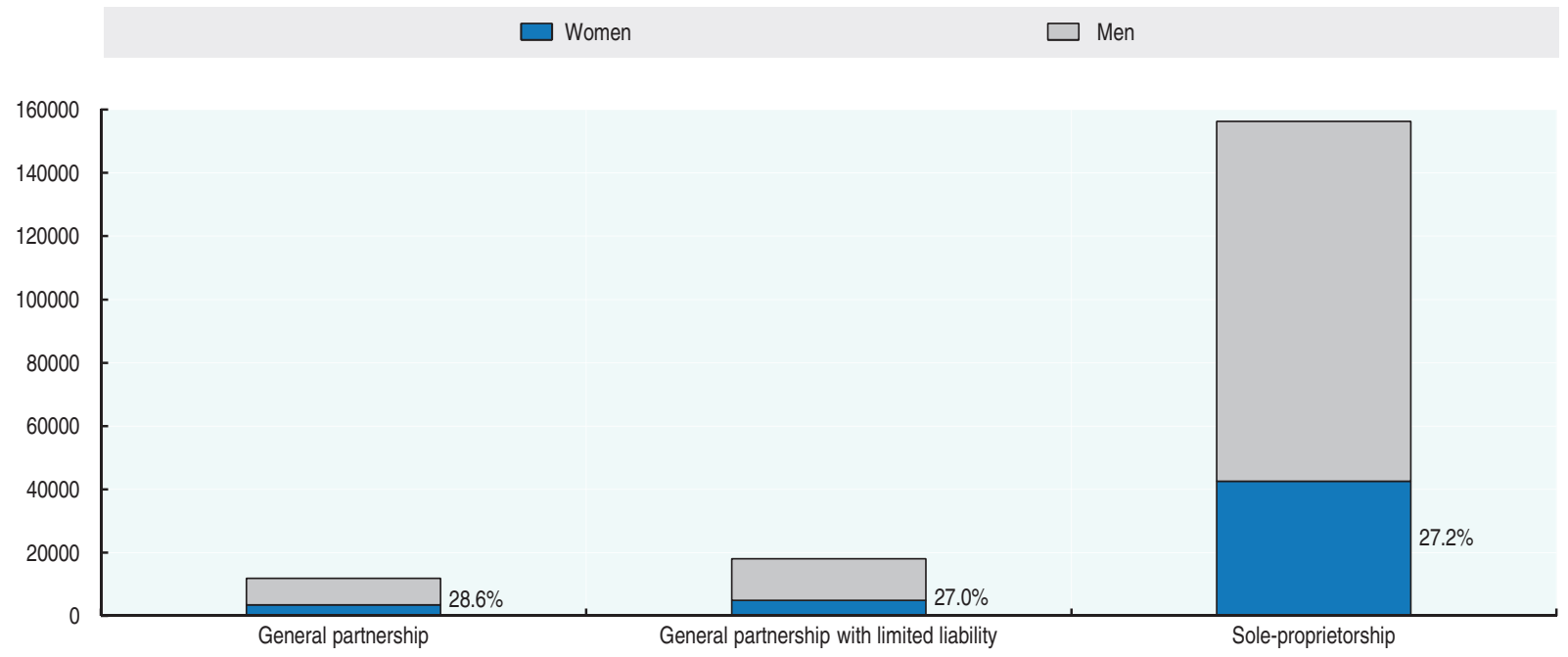

Source: Statistics Norway, Ownership and roles in business enterprise sector. 
Another relevant conceptual issue is how and whether to account for changes in ownership in the derivation of the demographic indicators. Within the EIP framework, the interpretation of "birth" as the generation of a completely new enterprise suggests to not equate shifts in ownership (a man purchasing the enterprise of a woman, or vice versa) with births of women or men enterprises, but rather to try to capture ownership changes through a specific indicator in a later stage. According to the same line of reasoning, the production of the survival and growth indicators should be based on the legal status of the enterprise at the first year of observation. An enterprise with a woman sole-proprietor in $t$ and surviving until $t+3$ is included in the count of surviving enterprises even if it changes legal status between $t$ and $t+3$.

Of course, even the most developed linked registers do not provide information on key characteristics of the entrepreneurs, such as motivations to start the business, selfassessment of business conditions and business development, and satisfaction at work. This information can be only provided by specially designed surveys.

\section{Comparing women and men enterprise using firm-level surveys}

The use of firm-level survey data for the construction of statistics on entrepreneurship by gender is hampered by the lack of a common international framework for the design of business surveys. There are relatively few surveys that collect information on the owners. Among the few ones available, comparability is made difficult by i) the fact they refer to different populations of enterprises (often focusing on SMEs but with different size thresholds for inclusion in the sample), ii) their focus on particular categories of enterprises (start-ups/recently created enterprises, firms in high-technology industries), iii) differences in questions related to ownership, with related problems concerning the definition of women enterprises.

The only known example of international data collection of enterprise data with a focus on the "individuals behind the business" is the Factor of Business Success (FOBS), coordinated by EUROSTAT and implemented by 15 European countries. The FOBS focuses on newly born enterprises and characteristics of their founders. It was conducted as a one-off survey, within the framework of the data collection on business demography, on a sample of enterprises in the business registers stratified by activity and employee size. Using a relatively light questionnaire, the FOBS managed to collect comparable information on key elements of enterprise performance and on owners' characteristics, motivations, and subjective evaluation of the business. The results of the survey are very informative. For instance, it appears that across European countries, enterprises founded by men tend to be relatively more involved in export activities, with the exception of enterprises founded in Italy, Portugal and Sweden (Figure 1.5).

The FOBS survey is similar in content, design and focus to the Repertoire SINE in France. SINE surveys a sample of entrepreneurs from businesses in the SIRENE register at the date of the creation of the firm, and three and five years after the creation. Different panels of young firms (created in 1994, 1998, 2002, 2006 and 2010) in SINE allows the monitoring over time of entrepreneurs' conditions and strategies at the start and in the first years of entrepreneurial activity. A key strength and uniqueness of the SINE surveys is their longitudinal design. ${ }^{5}$ Using SINE data referring to enterprises born in 2006, it is possible to observe that the survival rates of newly created women and men enterprises are highly dependent on the experience in the business activity of the founder before the start-up (Figure 1.6). Once we control for the founders' experience (50\% of men founders have three 
Figure 1.5. Europe: Firms exporting by gender of the founder, 2005

Percentage

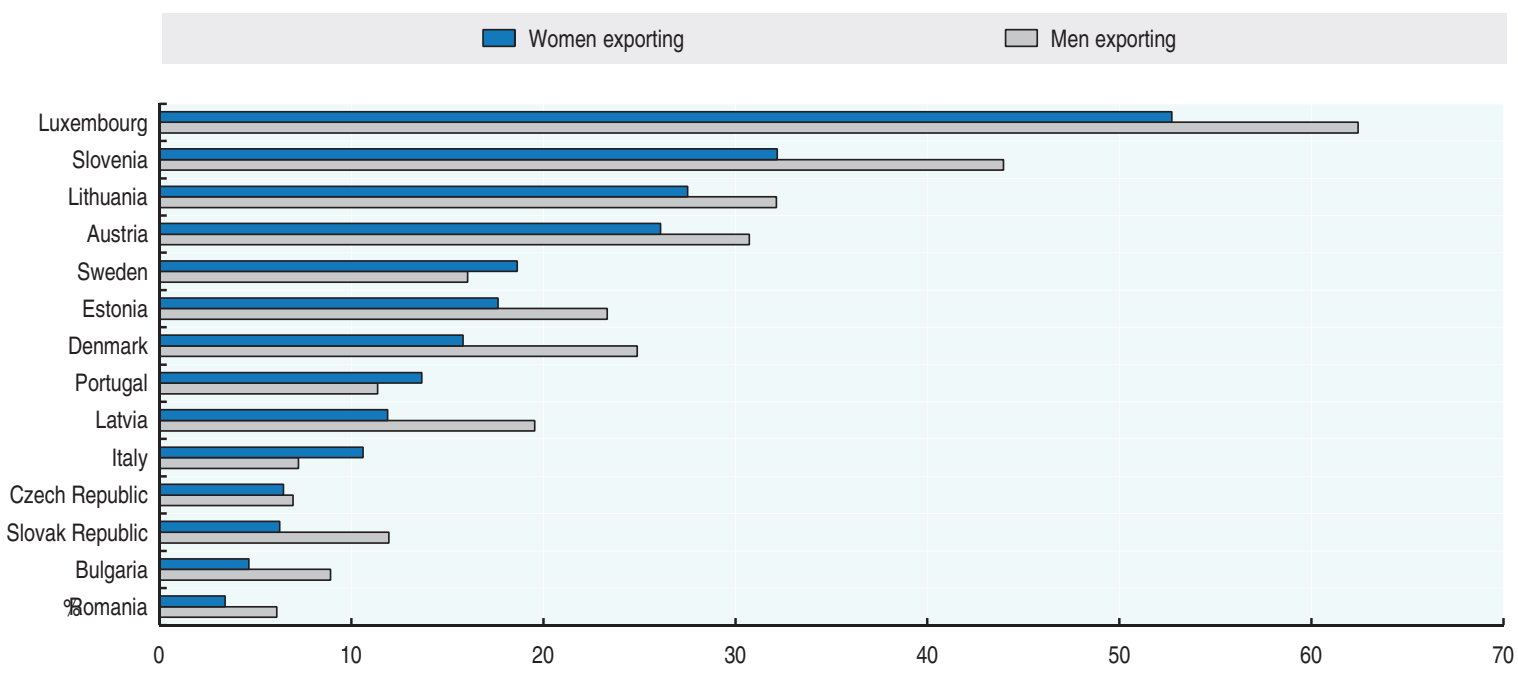

Source: EUROSTAT Factors of Business Success Survey.

\section{Figure 1.6. France: Survival rates of enterprises created in 2006 by gender of the founder}

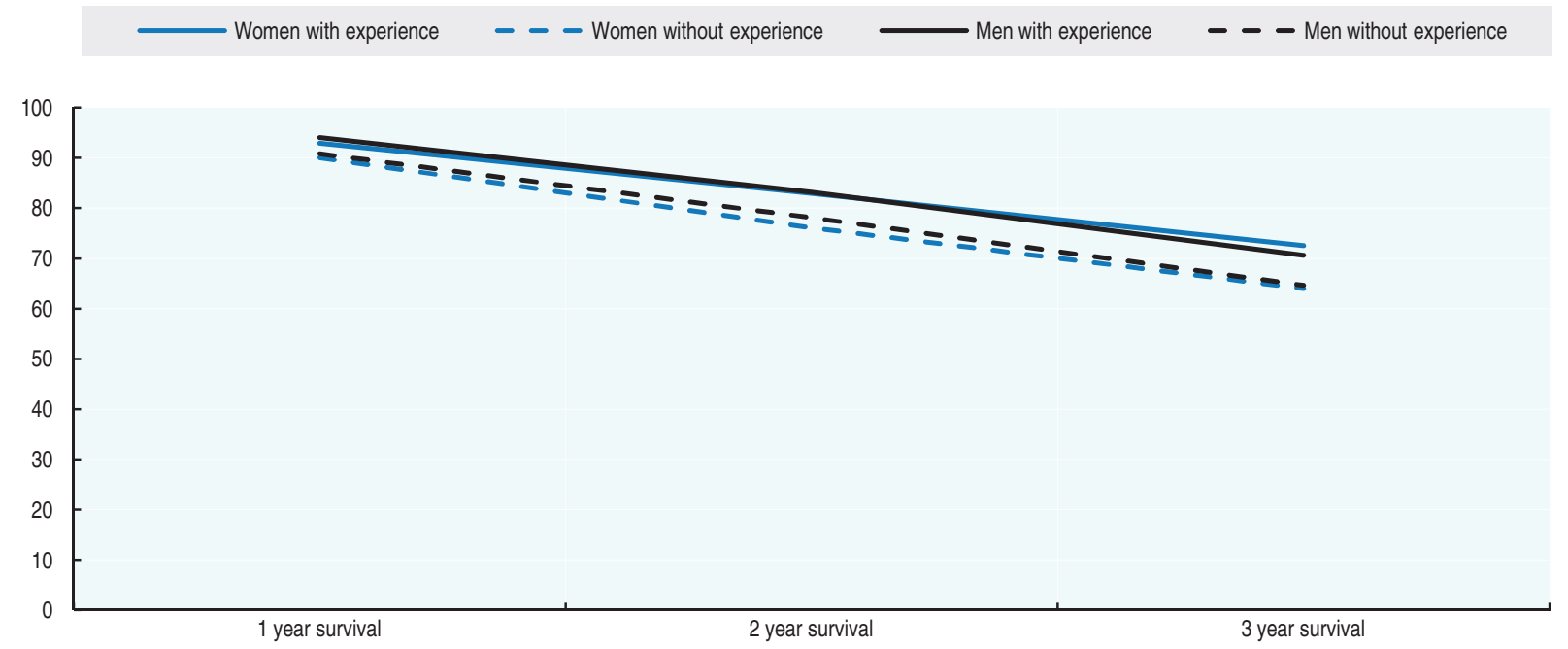

Source: Own calculations based on INSEE Système d'information sur les nouvelles entreprises, 2006 wave.

years or more experience, while only $40 \%$ of women have this level of experience), statistically significant differences in survival rates by gender are no longer observed. This example shows how the combination of information on characteristics of the enterprise and on characteristics of the founder can yield significant insights on drivers and policy levers for entrepreneurship. ${ }^{6}$

A different example of survey providing information that can be disaggregated by gender is the Survey of Business Owners (SBO) in the United States. The SBO is conducted every five years by the US Census Bureau (the last available data refer to 2007). Its universe comprises all the operating firms with receipt of USD 1000 or more that filed tax forms as 
individual proprietorship, partnership or any type of corporation. Data can be tabulated by gender, ethnicity and race, on the basis of the characteristics of the owners that possessed $51 \%$ or more of the stock or equity in the business. Two other characteristics of the SBO are worth mentioning. First, it includes information on business inheritance, business ownership among family members, and owner's experience in working for a family business. This allows disentangling the role of family-factors behind the entrepreneurial decisions (possibly differentiating "exploiter" of existing activities from "creators" of a new business). Second, the universe for sampling takes into account estimated probabilities that businesses are minority or women-owned. ${ }^{7}$ In the United States, the number of women enterprises increased more markedly than the number of men enterprises between 2002 and 2007 (Figure 1.7). This positive change is due to a large increase in the number of non-employer firms, as the estimated number of men and women employer enterprises decreased during the period. Figure 1.7 also shows that the number of workers employed by women enterprises increased during the period, while it decreased for men enterprises.

\section{Figure 1.7. United States: Changes in number and employment of enterprises by gender of owner, 2002-07}

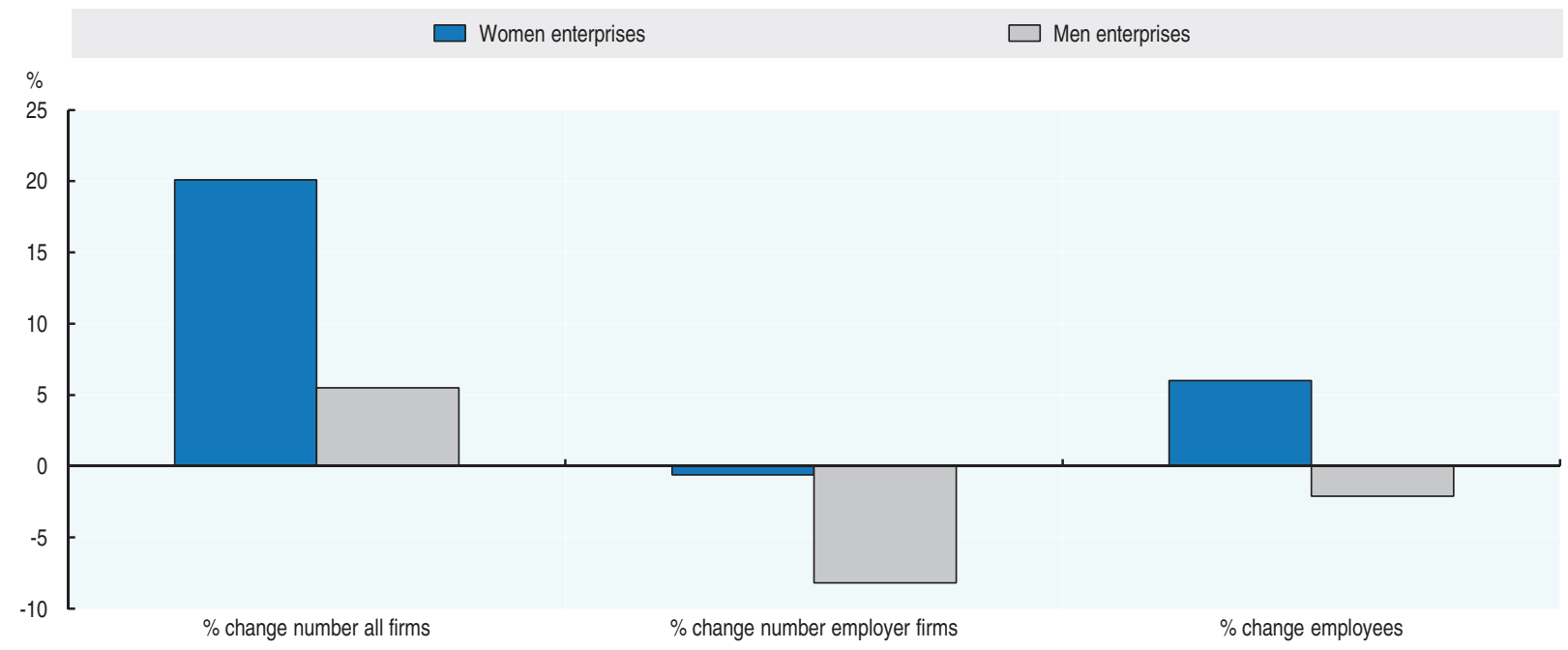

Source: Selected statistics from US Census Survey of Business Owners 2007, summary of main findings, www.census.gov/econ/sbo/ get07sof.html?12.

StatLink AाIs http://dx.doi.org/10.1787/888932596821

In the medium and long run, knowledge on the relationship between characteristics of entrepreneurs and the performances of their enterprises could be advanced through a harmonised survey, implemented at regular intervals by National Statistical Institutes. The examples presented above show that an international survey, based on a light and harmonised questionnaire, could be a technically feasible and policy-relevant undertaking. Further discussions should verify the sustainability of the costs related to the implementation of a new survey. Moreover, an open question is whether this collection of information should focus on newly founded enterprises (start-ups) and their founders, or on the existing population of enterprises and their owners. The response burden on enterprises from a new survey can be reduced by integrating it closely to the standard collection of business demography statistics. This means that surveyed enterprises must 
be sampled from the business registers, so that information on employment, turnover, industry, etc. can be extracted directly by the registers. This integration would allow the monitoring of measures of enterprise performance (exit, employment and turnover growth) in the years following the initial survey without the need of a longitudinal design, since information from the business registers can be used.

\subsection{Future developments}

The operational definition of entrepreneurs presented in this chapter can be used as a tool for new analysis of the links between the characteristics of the business owners and the performance of enterprises. This analysis needs to be supported by a co-ordinated international effort of data collection and harmonization. The initial focus on gender is justified by the policy relevance of women's entrepreneurship and by the current lack of quantitative information that is comparable cross-country. However, definitions and methods used for this first analysis can be adapted to extend the focus to other policyrelevant issues, such as migrant entrepreneurship.

Policy-relevant evidence on women's entrepreneurship can be produced by developing indicators organised along three main axes, or pillars:

1. Business demography indicators for women and men-owned enterprises.

2. Characteristics of women and men entrepreneurs.

3. Determinants of women's entrepreneurship.

The development of international statistics along these three pillars will be based on the integration of information from firm-level data (mostly used for pillar 1), populationbased data (pillar 2), and secondary data sources on the business and policy environment

Table 1.1. Data sources on women's entrepreneurship and their use

\begin{tabular}{|c|c|c|}
\hline Advantages & Limitations & Methodological issues \\
\hline \multicolumn{3}{|l|}{ Business registers } \\
\hline $\begin{array}{l}\text { Possibility to develop yearly indicators of } \\
\text { entrepreneurial performance, disaggregated by gender } \\
\text { (or other characteristics) of the owner. The economic } \\
\text { relevance of women's entrepreneurship can be } \\
\text { quantified, and compared across countries. }\end{array}$ & $\begin{array}{l}\text { A limited number of countries have an established } \\
\text { system of linked register and population data. } \\
\text { Beyond gender and nationality (or citizenship), } \\
\text { the information available on the owners is often limited. }\end{array}$ & $\begin{array}{l}\text { The main issue is how to define women and men } \\
\text { enterprises when there is more than one owner. } \\
\text { Information on the distribution of shares, equity and } \\
\text { interests among the owners is needed, but this } \\
\text { information is often not available or difficult to integrate } \\
\text { in the business registers. For indicators limited to } \\
\text { sole-proprietorships, comparability issues arise from } \\
\text { different legal definitions of sole-proprietorship across } \\
\text { countries and different incentives to incorporate the } \\
\text { businesses. }\end{array}$ \\
\hline \multicolumn{3}{|l|}{ Population surveys } \\
\hline $\begin{array}{l}\text { Rich information on personal characteristics of the } \\
\text { self-employed, with and without employees. Trends } \\
\text { in entrepreneurial activity of men and women can } \\
\text { be described for a large number of countries and } \\
\text { over time. }\end{array}$ & $\begin{array}{l}\text { High heterogeneity of the population of self-employed } \\
\text { (not all the self-employed are entrepreneurs). } \\
\text { Very limited information on characteristics of } \\
\text { the business besides its size and industry. }\end{array}$ & $\begin{array}{l}\text { Comparability issues created by the statistical } \\
\text { treatment of incorporated self-employed. More } \\
\text { harmonisation work needed to derive comparable } \\
\text { figures on income from self-employment. }\end{array}$ \\
\hline \multicolumn{3}{|l|}{ Surveys of businesses and their owners (founders) } \\
\hline $\begin{array}{l}\text { Possibility to study through multivariate analysis } \\
\text { the sorting of women and men in different types } \\
\text { of entrepreneurial activities. Possibility to analyse } \\
\text { the role played by characteristics of the owners } \\
\text { (or founders) on the growth cycle of the business. } \\
\text { Information on individual motivations, difficulties } \\
\text { and expectations can be collected. }\end{array}$ & $\begin{array}{l}\text { The internationally harmonised firm-level surveys } \\
\text { already available do not generally collect information } \\
\text { about the individual owners or founders. The available } \\
\text { surveys crossing information on businesses and } \\
\text { owners focus on different populations (start-ups, } \\
\text { SMEs or the whole population of active enterprises) } \\
\text { and use very different questionnaires. }\end{array}$ & $\begin{array}{l}\text { More work needed to set a strategic platform for } \\
\text { the collection of firm-level surveys which are } \\
\text { internationally comparable. New solutions, including } \\
\text { better integration of information from survey and } \\
\text { from business registers, need to be experimented } \\
\text { to reduce the burden on respondents and on Statistical } \\
\text { Institutes. }\end{array}$ \\
\hline
\end{tabular}


(pillar 3). The EIP can contribute to take stock of the different sources of data already available, proposing solutions to reduce the pending methodological and comparability issues.

Analysis based on these new data has the potential of increasing the collective understanding of the state and determinants of entrepreneurship, and of becoming a much needed tool for policy makers. Moreover, this work can guide future developments of statistics on both enterprises and entrepreneurs, through a knowledge sharing on best statistical practices. Such harmonisation in methods can be extremely relevant for developing countries in the process of developing their own statistical knowledge base on entrepreneurship.

\section{Notes}

1. Information on the type of employment searched for by the currently unemployed is only available for a subset of labor force surveys for OECD countries (notably, the Eurostat harmonised labor force surveys). These data show that in all European countries with the exception of Luxembourg, unemployed women are less likely than men to search for a job as self-employed. This might indicate that women have either lower preferences for business ownership, or lower expectations to enter in the labor force as self-employed.

2. Measurement of income from self-employment is one of the most difficult areas for income distribution analysis. The EU-SILC provides detailed guidelines on the criteria that should be followed for the calculation of self-employment income. However there are still methodological hurdles that reduce the comparability of the statistics across countries and across times. In fact, the self-employed often have accounting practices which make it difficult for them to provide accurate responses to survey questions. Moreover, their financial and accounting framework does not relate well to that used by statisticians in constructing national accounts or household income analysis (Eurostat, 2010).

3. This residual category can cover enterprises managed by couples, with equal participation of men and women, or with participation of a legal entity so that neither men nor women can claim ownership over the majority of the shares.

4. For Mexico, data on sole-proprietor enterprises are produced using the Economic Census 2009.

5. Some of these surveys have been conducted at the national level by research institutes and private foundations (e.g. the KFW/ZEW start-up survey in Germany and the Kauffman Firm Survey in the United States), and tend to oversample particular types of enterprises, such as those in hightechnology sectors.

6. Another relevant example is the survey on new entrepreneurs undertaken by Statistics Denmark in 1999. The survey collects information on motivations, barriers for start-up and continuation, framework condition and types of cooperation of the entrepreneur. The survey was meant to complement the data on entrepreneurs made available through the linkages of business and population registers. It focuses only on new enterprises, defined as "a business unit that has not been directed by another owner, has not existed under another type of ownership, has not been a subsidiary of another firm or owned by a person who is already registered for activities liable to VAT" (see Boegh Nielsen, 2001).

7. These estimates are based on the combination of different secondary data sources and techniques (e.g. analysis of word strings in the company name indicating possible minority ownership).

\section{References}

Ahmad N. and A. Hoffman, (2008), "A Framework for Addressing and Measuring Entrepreneurship", OECD Statistics Working Papers 2008/2, OECD Paris.

Bank of Montreal Institute for Small Business. "Myth and realities: The economic power of women-led firms in Canada". 
Blanchflower, D.G and A.J. Oswald (1998), "What Makes an Entrepreneur?”, Journal of Labor Economics, University of Chicago Press, Vol. 16(1), January.

Boegh Nielsen, P. (2001), "Statistics on Start-ups and Survival of Women Entrepreneurs: the Danish Experience", in Women Entrepreneurs in SMEs. Realising the Benefits of Globalisation and the Knowledgebased Economy, OECD Publishing.

Djankov S., Miguel E., Qian Y., Roland G., and E. Zhuravskaya (2005), “Who are Russia's Entrepreneurs?”, Journal of the European Economic Association, MIT Press, Vol. 3(2-3).

Eurostat (2010), "EU-SILC 2008. Description of target variables: Cross-sectional and Longitudinal”, Eurostat.

Fairlie, R.W. and A.M. Robb (2009), "Entrepreneurship, Self-Employment and Business Data: An Introduction to Several Large, Nationally-Representative Datasets", IZA Discussion Papers 4052, Institute for the Study of Labor (IZA).

Hipple, S. (2010), "Self-employment in the United States”, Monthly Labor Review, September.

Kihlstrom, R E and J. Laffont (1979), "A General Equilibrium Entrepreneurial Theory of Firm Formation Based on Risk Aversion", Journal of Political Economy, University of Chicago Press, Vol. 87(4), August.

Jung O. (2010), “Women Entrepreneurs”, Small Business Financing Profile, Industry Canada.

Langlois, R.N. (2007), "The Entrepreneurial Theory of the Firm and the Theory of the Entrepreneurial Firm”, Journal of Management Studies, Wiley Blackwell, Vol. 44(7), November.

Lazear, E.P. (2005), “Entrepreneurship”, Journal of Labor Economics, University of Chicago Press, Vol. 23(4), October.

Letowski, A. (2001), “Comment améliorer la connaissance statistique des femmes chefs d'entreprise?", in Women Entrepreneurs in SMEs, Realising the Benefits of Globalisation and the Knowledge-based Economy, OECD Publishing.

Lotti, F. (2006), “Entrepreneurship, is there a gender gap?", Working Paper, available at https:// mail.sssup.it/ lotti/gender_gap.pdf.

OECD (2004), “Women Entrepreneurship. Issues and Policies”, Issues Paper, OECD Paris.

OECD (2011), Entrepreneurship at a Glance, OECD Publishing.

OECD (2001) "Issues related to Statistics on Women's Entrepreneurship", Paper presented at the Workshop on Firm-level Statistics, 26-27 November 2001, OECD Paris.

Peña Parga X. and C. Mondragón-Vélez (2008), "Business Ownership and Self-Employment in Developing Economies: The Colombian Case”, Documentos Cede 004672, Universidad De Los Andes-Cede.

Van Stel, A. (2004), "COMPENDIA: Harmonizing business ownership data across countries and over time”, Scales Research Reports N200413, EIM Business and Policy Research. 

PART I

Chapter 2

\section{Measuring Entrepreneurial Finance: A European Survey of SMEs}


E mpirical studies conducted mainly at the country level support the relevance of access to finance as a determinant of entrepreneurship (Kerr and Nanda, 2009). There have been, however, limited efforts at producing sound internationally comparable data on the financing of new and small enterprises. This chapter addresses some of the challenges inherent to collecting statistics on entrepreneurial finance; it focuses, in particular, on data on the demand for finance by young and small enterprises and on the conditions they face in accessing finance. It thus complements the work of Financing SMEs and Entrepreneurs: An OECD Scoreboard (OECD, 2012), which presents national data mainly on the supply side of finance sourced from Central Banks or from surveys of finance suppliers. The Scoreboard also includes demand-side data collected by surveys undertaken by both private and pubic institutions. However, the Scoreboard recognises that improvements are required as concerns demand-side data and encourages "international, regional and national authorities as well as business associations to work together to harmonise quantitative demand-side surveys in terms of survey population, questions asked and timeframes".

Business surveys on access to finance exist in a number of countries to monitor over time the sources and conditions of internal and external financing by small and mediumsized enterprises (SMEs) and identify possible constraints and failures justifying the need for policy interventions. These surveys, managed by governmental and/or non-governmental bodies, yield relevant information on impediments to financing faced by new and small firms in a given country and by particular groups of businesses within the country, such as young enterprises or women-owned enterprises. Though, in light of the scope of each of these surveys and the specific focus they might have (e.g. the investigation of financing for high-growth enterprises, the analysis of changes in the credit conditions, the financial structure of small enterprises) comparisons of results across countries are subject to limitations. Currently, periodic international business surveys on access to finance exist only at the European level, produced by European Union's institutions. One of these European surveys constitutes the object of this chapter. Data from the World Bank Enterprise Survey (module on finance), also allow cross-country comparisons, although typically for different subsets of countries for each reference year, with only a few OECD countries covered.

A careful examination of the main national and international business surveys on access to finance that are or have been conducted on a regular basis points to differences not only in the selection of topics covered by each survey but also in the formulations of queries asking identical or quasi-identical questions. The coverage of firms also varies, with surveys using diverse definitions of SMEs and size class breakdowns (for instance, including or not zero employees firms, or firms with more than 99 employees). For these reasons, the wealth of information available on SME access to finance cannot be fully exploited for international analysis.

This chapter presents the key features of the 2010 international Eurostat business survey on SME access to finance. This survey provides an illustrative case of a co-ordinated effort by several statistical offices to collect harmonised statistics on access to finance, 
ensuring cross-country comparability of findings. The results of the survey allow comparative and specific analysis of EU Member States; in 2011, Eurostat and several countries (including Denmark, Finland, Ireland, Luxembourg and Spain) issued reports on the survey findings. ${ }^{1}$

Table 2.1. Business surveys on access to finance

\begin{abstract}
National surveys
Canada - Statistics Canada

Survey on Financing of Small and Medium-sized Enterprises

Canada - Industry Canada

Credit Conditions Survey

United Kingdom - Consortia of private and public

organisations $^{1}$

Surveys of SME Finances

United Kingdom - Department for Business, Innovation and Skills

2009 Finance Survey of SMES

United States - Federal Reserve Board

Survey of Small Business Finances - discontinued

This triennial survey measures the demand and analyses sources of financing of Canadian SMEs (with fewer than 100 employees), including data on the application process, firm profiles and demographic characteristics SME ownership. Results cover seven industry groupings, five employment sizes, six geographic regions and This survey was conducted in May and June 2011 to complement the Survey on Financing SMEs. It focused on financing sought by enterprises with 1 to 99 employees during 2010.

These surveys, conducted in 2004, 2007 and 2008, provide a close analysis of SMEs, their owners and access to finance. The surveys are based on representative samples of UK businesses with less than 250 employees.

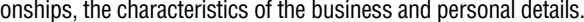

businesses that obtained bank finance in 2009 . 500 employees) in the United States. The survey included questions on owner characteristics, firm size, use of financial services, and the income and balance sheets of the firm. It was conducted in 1987, 1993, 1998, and for
\end{abstract}

International surveys

European Commission and European Central Bank (ECB) ${ }^{2}$

Survey on the Access to Finance of Small and Medium-sized Enterprises

ECB

Survey on the Access to Finance of Small and Medium-sized Enterprises

Eurostat

Survey on SME Access to Finance

World Bank

Enterprise Survey, Section K: Finance: sources of finance, access to credit

1. The first survey was carried out in 2004 by the Centre for Small and Medium-Sized Enterprises (CSME), Warwick Business School, with funding from a large consortium of private and public sector organisations led by the Bank of England. A second survey was conducted by the University of Cambridge in 2007 and the third was again carried out by CSME in 2008 with funding from the ESRC and Barclays Bank.

2. The survey was conducted by the Gallup Organisation in 2009 and Ipsos MORI in 2011.

\subsection{Finance needs and sources}

Eurostat's Survey on access to finance was conducted in 2010 in 20 European countries: Belgium, Bulgaria, Cyprus, ${ }^{2}$ Denmark, Finland, France, Germany, Greece, Ireland, Italy, Latvia, Lithuania, Luxembourg, Malta, Netherlands, Poland, Slovakia, Spain, Sweden and the United Kingdom. The survey was made possible by an implementing provision to use the flexible module of the European Parliament and Council Regulation on Structural Business Statistics. ${ }^{3}$

The purpose of the survey was to investigate the constraints on the availability of finance and how they may be changing over time. It also aimed at assessing future needs by type and source of finance.
This survey, launched in 2009, is conducted every two years in all EU countries and other countries associated to EU programmes (Albania, Croatia, FYROM, Iceland, Israel, Liechtenstein, Montenegro, Norway, Serbia, including applications, approvals and rejections) and expectations of SMEs in the six preceding of the firms.

Part of the more comprehensive $E C B / E C$ survey is conducted by the ECB every six months to assess the latest

This is a one-off survey conducted in 2010. It covers three areas: ownership situation, finance type sought, and need for guarantees; degree of success, choice of financial institution and reasons of partial success or business growth.

The module K of the WB Enterprise Survey focuses on the financial structure of the firm and the use of internal and external finance for normal business operations, special projects or investments. 
A task force composed of both users and providers of statistics on business finance met regularly throughout 2009 and 2010 to discuss the concept and design of the survey: the draft EC Regulation that formed the basis of the survey, the harmonised questionnaire (translated into the national languages of participating countries), methods of grossing up sample results to national reference populations, how to deal with non-response items, the sampling, the sample size per country and the overall methodology to be employed. ${ }^{4}$

One important consideration in conducting the co-ordinated survey was to limit the burden on respondents and the costs to EU Member States. The survey questionnaire included only 14 questions, less than the maximum of 20 questions allowed for the flexible module in Eurostat's collection of structural business statistics. Whenever possible, information from administrative sources was employed. Moreover, none of the questions in the survey are quantitative, and therefore did not require retrieving information from company accounts. The questionnaire covered SME access to the main finance types; it also investigated the expected financing needs for the triennium 2010-13 as compared with the situation in 2010 and 2007. Annex A presents the survey questionnaire.

\section{The national samples}

The survey covered only those enterprises responding to the following characteristics:

- classified in NACE Rev 2 codes B to N excluding K (financial services sector);

- independent, i.e. not a subsidiary of another business;

- existed at least since 2005;

- had between 10 and 249 persons employed in 2005;

- active in 2008;

- Had at least 10 persons employed in 2010.

The financial services sector has been excluded from the survey because means of obtaining finance for businesses in this sector are quite specific. Also, enterprises with less than 10 persons employed were excluded to keep administrative burdens low.

Several breakdowns were defined, in particular to allow the analysis of financial needs by economic sector and by enterprise growth. In light of the EU's efforts to boost employment and growth following the global financial crisis, it was deemed interesting to generate data to assess the conditions of access to finance for enterprises with different level of employment growth in recent years.

\section{Five distinct activity groups}

- Industry, NACE Rev. 2 codes B to E.

- Construction, NACE Rev. 2 code F.

- Services, NACE Rev. 2 codes $G$ to $N$ excluding J, $K$ and M.

- ICT services, NACE Rev. 2 code J.

- Professional, scientific and technical services, NACE Rev. 2 code M.

\section{Three sets of growth characteristics}

- gazelles;

- other high-growth enterprises;

- other businesses. All other businesses in scope of the survey. 
The definitions of high-growth enterprises and gazelles adopted follow closely the Eurostat-OECD Manual on Business Demography Statistics (Eurostat/OECD, 2007). Specifically, in the survey all enterprises with average annualised employment growth greater than 20\% per annum over the period 2005-08 were considered as high-growth enterprises. Among the high-growth enterprises, a distinction is made between the young ones, called gazelles, defined as being born in 2003 or 2004, and the other high-growth enterprises.

As expected, high-growth enterprises are a minority among all enterprises in the survey sample. In the target population of the survey in all 20 countries, only $6 \%$ of all enterprises are high-growth, and only $1 \%$ of all enterprises are gazelles. Even if the minimum sample required of 25000 enterprises across the 20 Member States was exceeded, the breakdown caused confidentiality problems, especially in small countries. For instance, Luxembourg did not have any gazelles in the reference period, and only two other high-growth enterprises were found in the target population. It was therefore decided not to consider them. Malta too had no gazelles, so enterprises were divided into only two groups: "high-growth enterprises" and other enterprises. The representativeness of these two types of enterprises depends on each country's response rate.

\section{The statistical methodology}

The breakdowns by activity group and enterprise characteristics resulted into 15 different strata per country. Random sampling without replacement was applied to each stratum. According to standard practice, the net sample required for each country was linked to the size of its economy. More enterprises than the expected net sample size were surveyed, as no statistical institute can a priori guarantee the number of responses actually received. Each Member State thus had to estimate the non-response rate from previous surveys conducted to obtain the number of questionnaires sent out.

Table 2.2. Response rate and sample size

\begin{tabular}{lrrr}
\hline \multirow{2}{*}{ Member States } & Net sample size & \multicolumn{2}{|c}{ Dataset size required } \\
\cline { 3 - 4 } & & $60 \%$ response & $80 \%$ response \\
\hline France, Germany, Italy, Spain, United Kingdom & 1800 & 3000 & 2250 \\
Belgium, Bulgaria, Greece, Ireland, Netherlands, Poland, Slovak Republic, Sweden & 900 & 1500 & 1150 \\
Denmark, Finland & 500 & 850 & 560 \\
Latvia, Lithuania & 300 & 400 & 400 \\
Cyprus, Luxembourg, Malta, & 233 & 300 \\
\hline
\end{tabular}

Specific procedures were adopted to treat the item "non-response" in the questionnaires, i.e. the lack of answer to a question although the business is eligible for that question. Indeed, a high number of "non-response" can decrease the quality of results from a survey. In some cases, missing answers were reliably inferred from other answers; in others, it was necessary to contact again respondents. Questionnaires containing many non-response items were typically excluded.

In addition, to avoid confidentiality problems, results were published by Eurostat only as percentage values, presenting the identification of a single respondent. However, to combine figures from different countries in an easier and more flexible way, "grossed-up" totals for the whole business population of each country were needed. Three techniques 
for projecting results of the survey to country totals were proposed, leaving to countries the choice of the technique(s) they considered the most appropriate. Annex $C$ provides information on the three techniques.

Eurostat gathered the grossed-up data collected by all Member States, applied the routine quality checks and calculated percentages. The published data can be found in the structural business statistics database of Eurostat. ${ }^{5}$

\section{Findings}

Three categories of finance were considered in the survey: loan finance, equity finance and other sources of finance, with the latter category covering a broad range of types and sources, from factoring and leasing to mezzanine or hybrid finance.

\begin{tabular}{ll}
\hline Loan finance & $\begin{array}{l}\text { This category includes loans from: the owner(s)/director(s); other employees of the business; family, friends } \\
\text { and other individuals outside the business; banks; and other loan sources (e.g. finance houses and subsidiaries } \\
\text { of banks). }\end{array}$ \\
This category includes equity finance from: existing shareholders; directors not previously shareholders; other \\
employees of the business venture capital funds; business angels; family, friends and other individuals not in \\
the categories above; initial public offering or other stock market offering; banks; other financial institutions \\
(e.g. finance houses and subsidiaries of banks); other businesses; and government equity finance sources.
\end{tabular}

An important objective of the Eurostat's survey was to understand the sources to which SMEs predominantly address their requests of finance. For that purpose, the survey collected detailed information on a comprehensive set of sources of finance within the three broad categories. The detailed breakdown is a distinctive feature of Eurostat's survey as compared to other business surveys on finance. The survey findings highlight the importance of a whole range of possible finance sources outside loans and equity finance, such as leasing and bank overdrafts and credit lines but also trade credit by suppliers and factoring.

Overall, the survey generated very valuable information on the modes and conditions of accessing finance by small and medium firms in Europe, providing policy makers with sound evidence on the situation across countries having different financial systems. The survey data support analyses on various relevant topics, including the impact of the global crisis on SME financing.

It is noteworthy that more than half of the companies in the survey did not seek any type of external finance in the two years of observation (i.e. 2007 and 2010), although the percentages of firms that sought external finance increased from 2007 to 2010 for all types of sources, i.e. loan, equity and other sources (Figure 2.1). Moreover, the results forecast a significant increase in finance needs for 2011 and 2013: more than 50\% of the enterprises indicated that they expected to need finance to maintain their business. The type of finance most requested by the surveyed enterprises is loans.

Data at the country level show that the percentages of enterprises requesting external finance vary considerably across European countries. In 2010, around $20 \%$ in Luxembourg, Netherlands and Denmark applied for loans, as opposed to $50 \%$ in Greece and the Slovak Republic (Figure 2.2). The percentages vary also for the category "other sources 
Figure 2.1. Firms seeking finance by type, EU20

Percentage

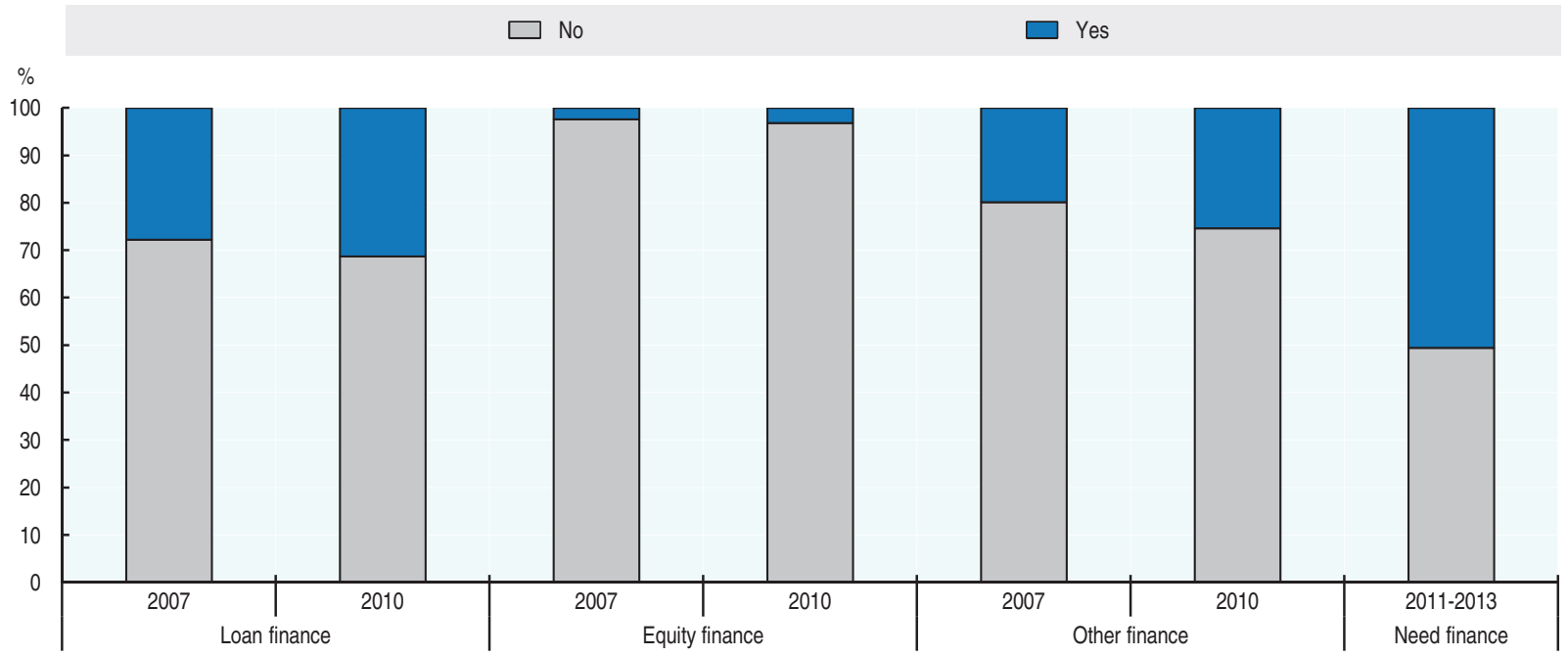

Note: EU20 covers the group of 20 countries that participated in the survey.

Source: Eurostat, Structural Business Statistics, Access to finance.

StatLink क्गाड

Figure 2.2. Firms seeking loan finance, $\mathbf{2 0 1 0}$

Percentage

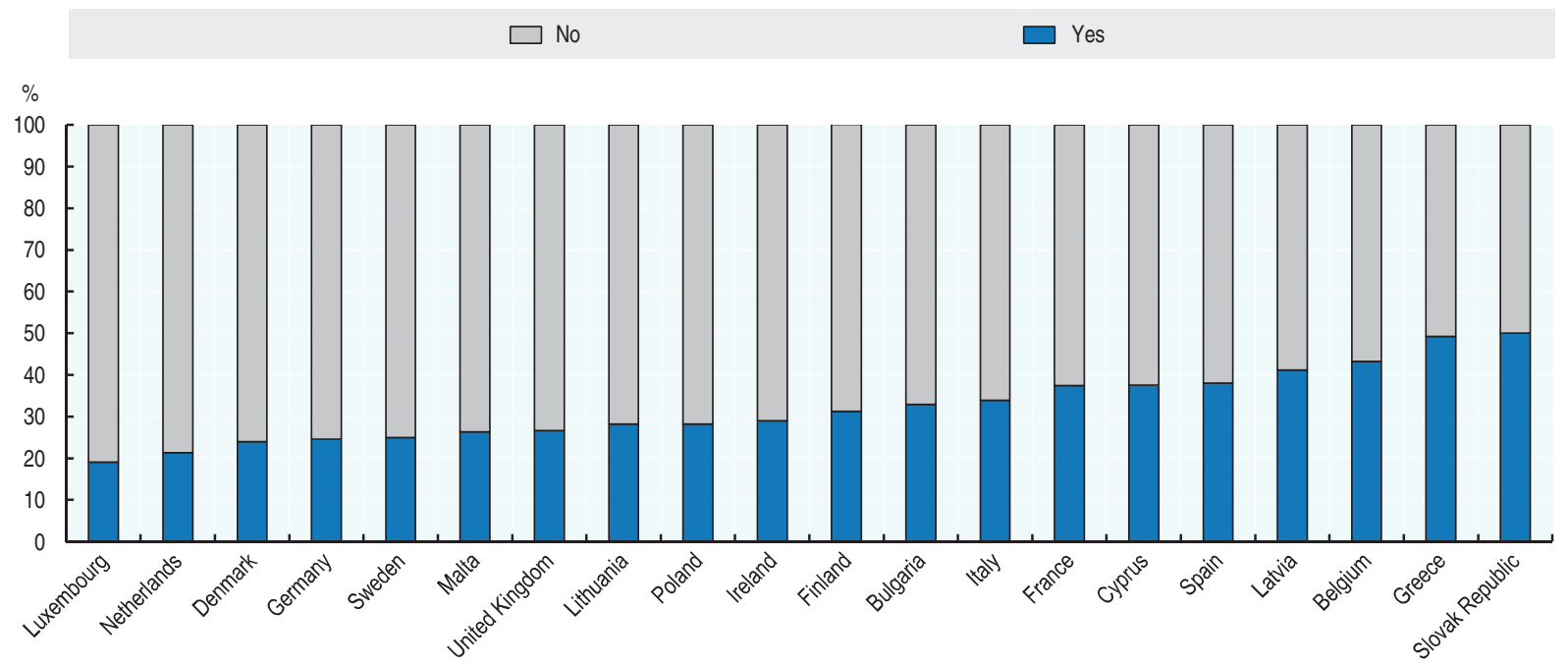

Source: Eurostat, Structural Business Statistics, Access to finance.

of finance": in 2010 only 10\% of Swedish enterprises requested finance other than loans or equity, contrasted with almost $40 \%$ of the surveyed enterprises in Latvia (Figure 2.3). Cross country differences with respect to equity finance are much less important. In all countries, tiny percentages of small and medium enterprises sought to obtain equity finance, with the exception of businesses in Greece and Luxembourg (Figure 2.4).

A detailed look at the numbers of applications for loan finance shows that banks are by far the most important source, followed by the owner(s)/director(s) of the business (Figure 2.5). Requests for equity finance are addressed prevalently to existing shareholders 
Figure 2.3. Firms seeking other finance, 2010

Percentage

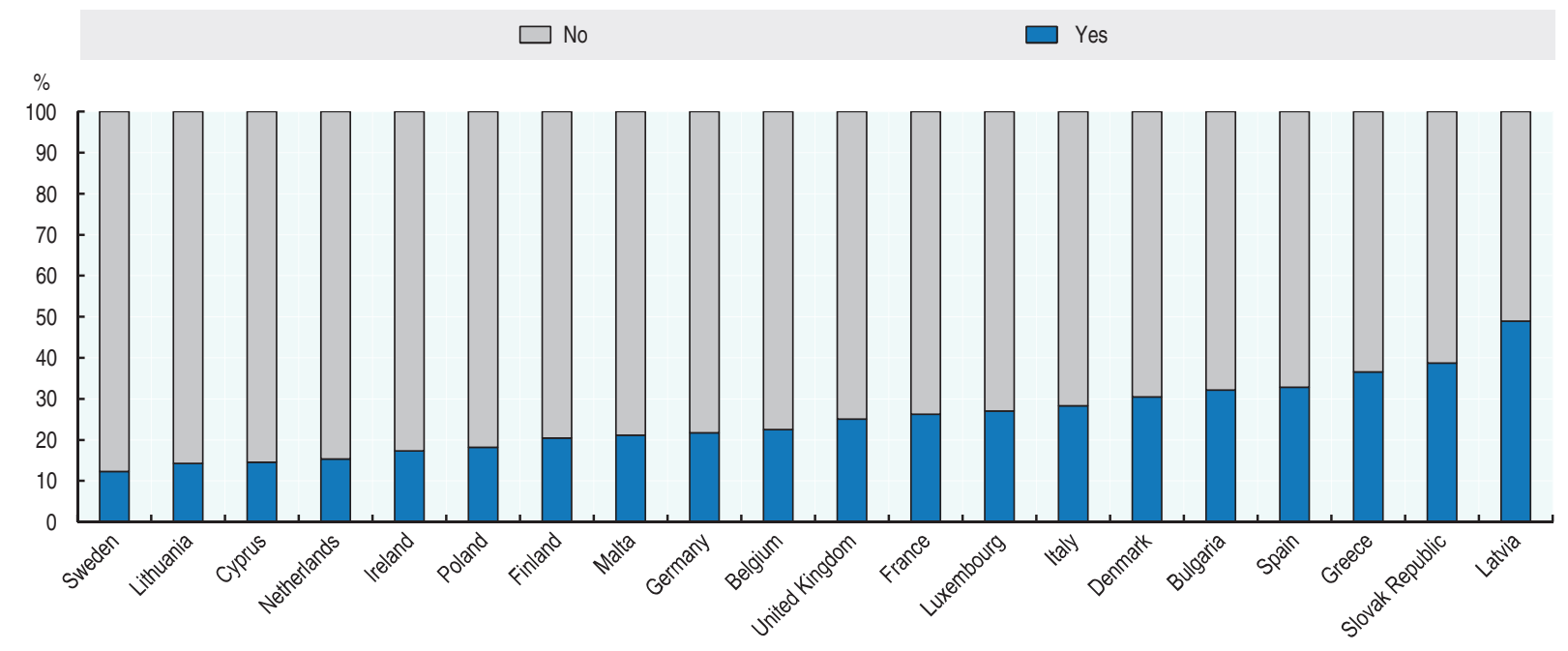

Source: Eurostat, Structural Business Statistics, Access to finance.

StatLink त्ञाs http://dx.doi.org/10.1787/888932596878

Figure 2.4. Firms seeking equity finance, $\mathbf{2 0 1 0}$

Percentage

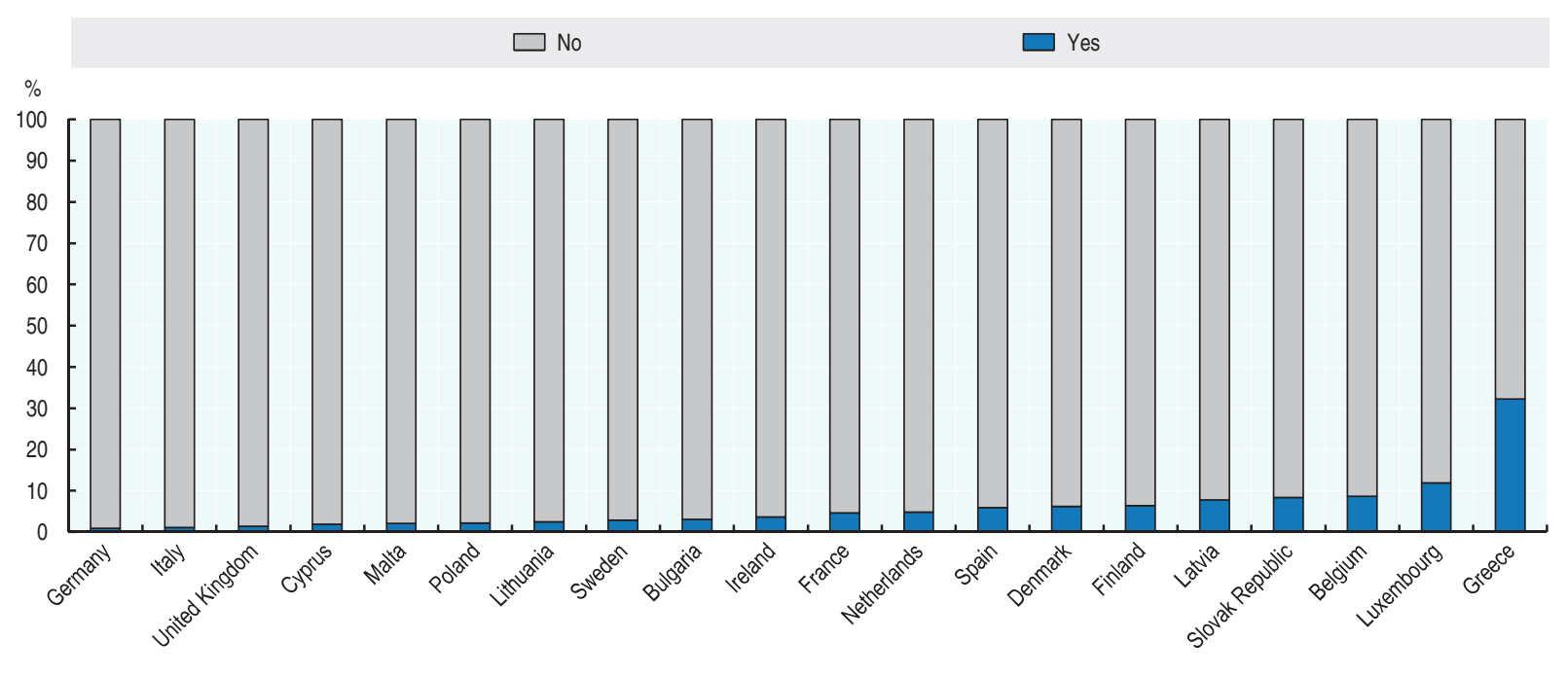

Source: Eurostat, Structural Business Statistics, Access to finance.

StatLink क्ताs http://dx.doi.org/10.1787/888932596897

and banks. In 2010, only 3 out of 100 firms in EU20 asked for equity finance and applications addressed to banks dropped by 7 percentage points compared to 2007. Among "other sources", leasing and bank overdrafts and credit lines are the most important types; however, between 2007 and 2010 the SMEs applying for leasing decreased while requests for overdrafts or credit lines slightly increased.

The survey also generated detailed information on the results of applications by financial sources before and during the financial crisis. At the EU level, the share of firms that were unsuccessful in their request for loan finance rose substantially from 2007 to 2010, independently of the source (Figure 2.6). The rate of unsuccessful requests to banks rose in 2010 by 7 percentage points compared with 2007 . 
Figure 2.5. Demand by source, firms seeking finance, EU20

Percentage

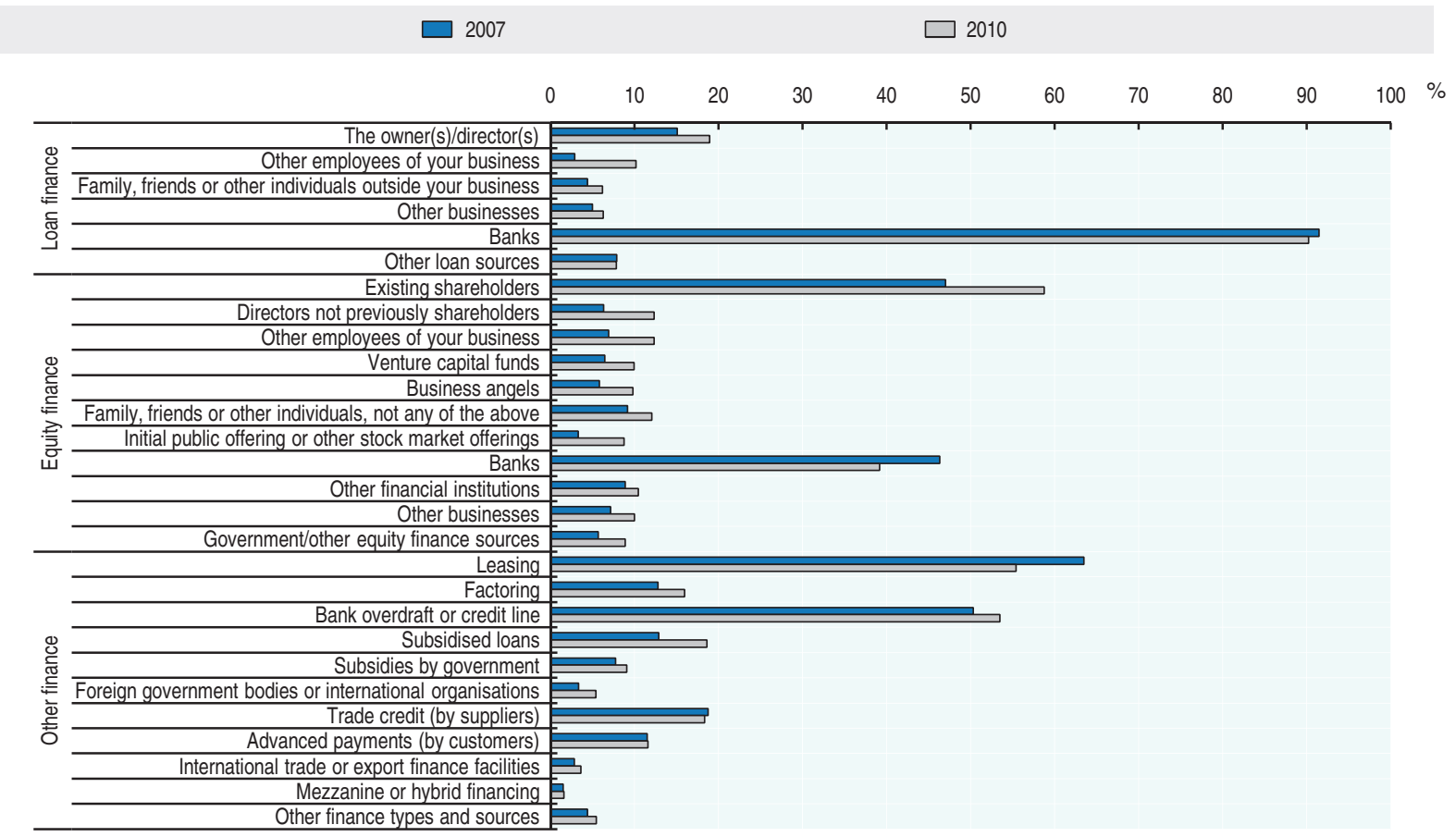

Note: EU20 covers the group of 20 countries that participated in the survey.

Source: Eurostat, Structural Business Statistics, Access to finance.

Figure 2.6. Rejection rate of loan requests by source, EU 20

Percentage

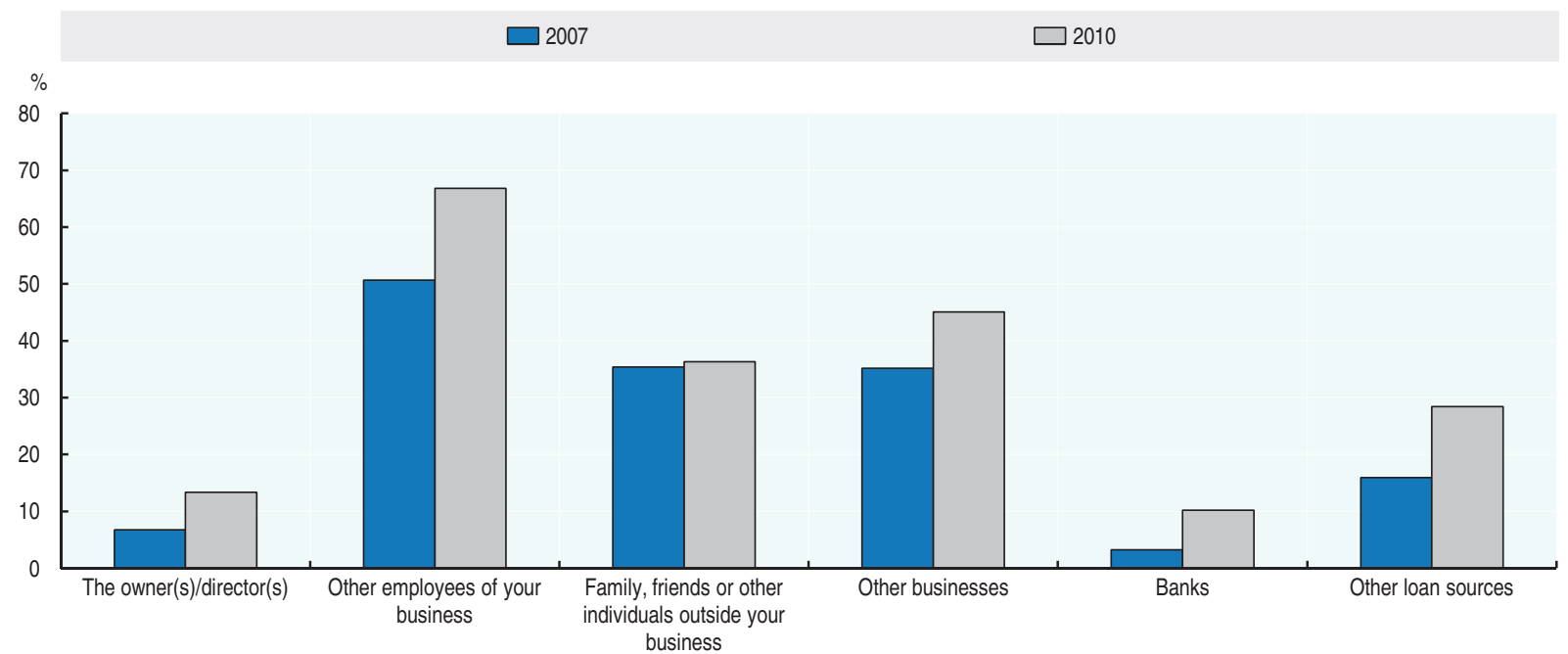

Note: EU20 covers the group of 20 countries that participated in the survey.

Source: Eurostat, Structural Business Statistics, Access to finance.

StatLink iाls http://dx.doi.org/10.1787/888932596935

The success rate for equity finance also decreased from 2007 to 2010 for all sources except "business angels", "initial public offerings (IPOs) or other stock market offerings" and "Other financial institutions" for which no substantive changes were registered 
(Figure 2.7). In addition, more requests were partially successful, meaning that either the firm received some funds but not the full amount requested, or that the terms of financing were not those initially required by the firm.

Figure 2.7. Success rate in obtaining equity finance by source, EU 20 Percentage

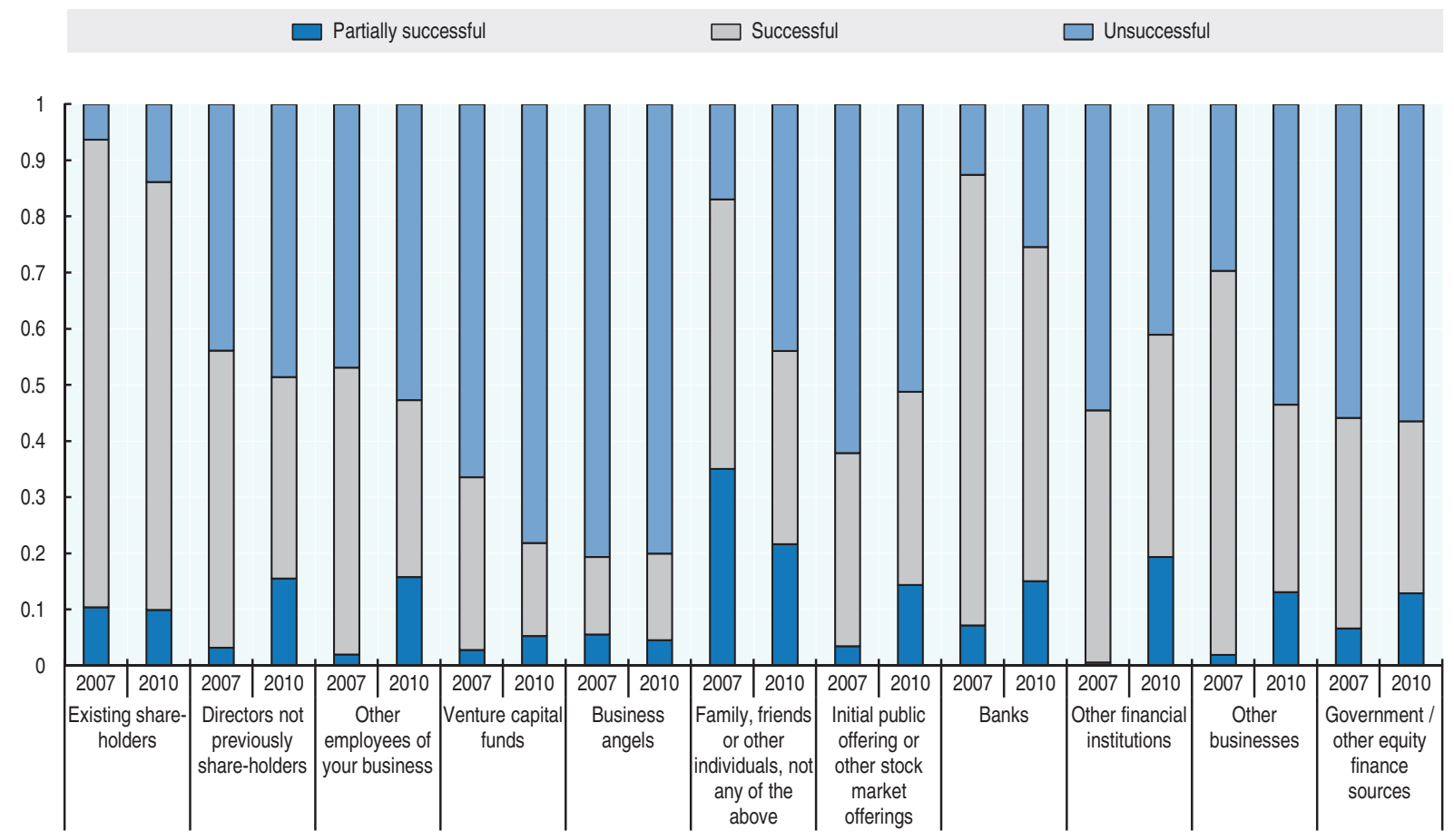

Note: EU20 covers the group of 20 countries that participated in the survey.

Source: Eurostat, Structural Business Statistics, Access to finance.

Finally, between 2007 and 2010 the rate of unsuccessful requests increased also in the category "other sources of finance" for most of the finance types, with the exception of the requests addressed to national and foreign governments or international organisations (Figure 2.8).

In addition to identifying the sources from which businesses wish to obtain finance and providing detailed results on the success rate of applications, the reasons for choosing a given source and the reasons for lack of success in obtaining finance, the survey produced statistics on financial needs of specific categories of enterprises, i.e. high-growth enterprises versus other enterprises. The main statistical findings include the following:

- A significant increase of finance needs in 2011-13.

- Over the period from 2007 to 2013 loans will remain the most desired finance type.

- Success rates in obtaining finance severely declined with the crisis.

- Firms reported that, in banks' opinion, the reason to refuse or partially refuse a loan related to businesses' lack of own capital. In the opinion of the businesses, however, the loans were not obtained because interest rates were too high.

- The main reported reason for businesses' choice of a particular bank for a loan is because they are already a client. 
Figure 2.8. Rate of unsuccessful requests in obtaining other finance by source, EU20 Percentage

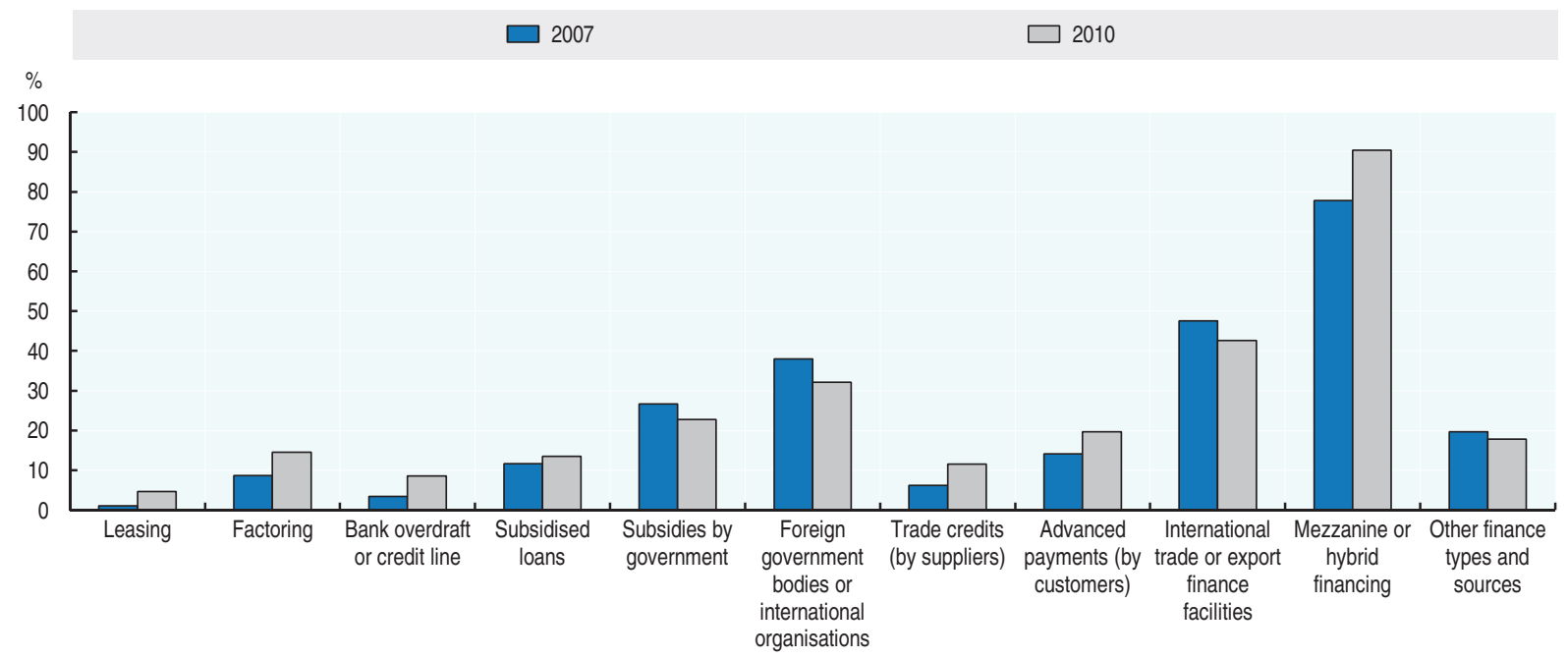

Note: EU20 covers the group of 20 countries that participated in the survey.

Source: Eurostat, Structural Business Statistics, Access to finance.

- Many companies considered the financial situation of their business as unchanged during the financial crisis, i.e. between 2007 and 2010.

- For the period 2011-13, the general economic outlook of the economy is perceived as the most likely factor limiting business growth, and not the financial constraints.

In summary, Eurostat's survey on access to finance has two main methodological strengths: good comparability across countries, due to the harmonised methodology and common questionnaire; and the use of business registers as sample frames which allowed, for instance, to stratify by growth performance of enterprises and to complete the information collected through the questionnaire with data from other administrative sources. A shortcoming of the survey is its lack of continuity, as it was done as a one-off exercise. Also, the survey does not contain quantitative information. The collection of quantitative data from the demand-side, combined with quantitative information from the supply-side, would provide a more comprehensive picture of access to finance.

\subsection{Towards internationally harmonised indicators}

Through business surveys countries investigate various dimensions of SME financing needs (e.g. the financial structure of enterprises, the use of finance, access constraints, etc.) depending on the policy questions they need to address at the country level. The heterogeneity of topics investigated by the surveys, but also the different formulations of questions exploring a same topic, make the international comparison of findings very limited when not impossible.

However, the national focus in a survey is not incompatible with the objective of ensuring comparability of results across countries. This could easily be achieved by including common questions in survey questionnaires designed at the country level. Future surveys should take the objective of international comparability systematically into 
account by introducing harmonised questions on access to finance for small and medium firms, covering the following broad themes:

i) Access to different types of finance, i.e. the extent to which enterprises use different categories of external finance and from what sources. The same broad categories of finance should be adopted in countries' survey.

ii) Measures of constraints with respect to enterprises' needs, i.e. whether or not enterprises have obtained the funds they requested.

iii) The main obstacles in accessing finance, focusing on costs, collaterals, and guarantees.

The harmonisation of key questions in national business surveys on access to finance would not increase their cost and/or the respondents' burden; by allowing international comparability, it would instead substantially enhance the surveys' value as support for policy design and analysis. The OECD has pionereed international efforts to develop data and statistical information on entrepreneurship and entrepreneurs' access to finance, through the OECD-Eurostat Entrepreneurship Indicator Programme and the OECD Scoreboard on SME and entrepreneurship finance. The OECD will continue to work in these areas, in cooperation with other international organizations, and favour dialogue across countries to improve data comparability. This, however, requires a commitment by national authorities to engage in harmonisation, at the international and, also, national level, as differences in definitions and survey design exist both across and within countries. The EU experience shows that supra-national institutions can play a role in favouring exchange of best practices and development of data collection standards. Financial institutions and national statistical offices have also relevant role to play, promoting harmonisation in definitions adopted in demand-side surveys and their matching, with the definitions and measurement adopted to collect supply-side data.

\section{Notes}

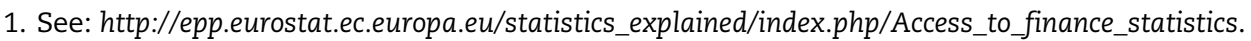

2. 1. Footnote by Turkey

The information in this document with reference to "Cyprus " relates to the southern part of the Island. There is no single authority representing both Turkish and Greek Cypriot people on the Island. Turkey recognizes the Turkish Republic of Northern Cyprus (TRNC). Until a lasting and equitable solution is found within the context of the United Nations, Turkey shall preserve its position concerning the "Cyprus issue".

2. Footnote by all the European Union Member States of the OECD and the European Commission The Republic of Cyprus is recognised by all members of the United Nations with the exception of Turkey. The information in this document relates to the area under the effective control of the Government of the Republic of Cyprus.

3. EC regulation http://eur-lex.europa.eu/LexUriServ/LexUriServ.do?uri=OJ:L:2009:033:0006:0007:EN:PDF; http://eur-lex.europa.eu/LexUriServ/LexUriServ.do?uri=OJ:L:2008:097:0013:0059:EN:PDF

4. The composition of the task force was the following: EUROSTAT (chair), NSOs from 20 participating countries, OECD, ECB, EIF, DG ENTR, DG ECFIN and DG REGIO.

5. The database is available at: http://epp.eurostat.ec.europa.eu/portal/page/portal/statistics/search_database.

\section{References}

BIS - Department for Business Innovation and Skills of the United Kingdom (2010), Results from the 2009 Finance Survey of SMEs, February. 
European Commission (2007), Evaluation of data and sources underlying the analysis of market gaps in access to finance for SMEs in the EU, report prepared by GHK/Technopolis for the DG Enterprise and Industry, July.

European Commission and European Central Bank (2001), Survey on the access to finance for SMEs, April to September 2011, survey questionnaire.

Eurostat/OECD (2007), Eurostat-OECD Manual on Business Demography Statistics, OECD Publishing.

Fraser, S. (2009), Small Firms in the Credit Crisis: Evidence from the UK Survey of SME Finances, University of Warwick.

Industry Canada (2011), Small Business Quarterly, Vol. 13, No. 3, November.

Industry Canada (2010), Credit Conditions Survey.

Kerr, W.R. and R. Nanda (2009), Financing Constraints and Entrepreneurship, Working Paper 10-013, Harvard Business School.

OECD (2012), Financing SMEs and Entrepreneurs: An OECD Scoreboard, OECD Publishing.

Statistics Canada (2007), Survey on Financing of Small and Medium Enterprises.

US Small Business Administration (2009), Small Business in Focus: Finance. A Compendium of Research by the Small Business Administration's Office of Advocacy, July.

World Bank (2011), The World Bank Enterprise Survey, Manufacturing Module 2011, questionnaire. 

PART II

\section{Entrepreneurship Indicators}





\section{STRUCTURAL INDICATORS ON THE ENTERPRISE POPULATION}

Enterprises by size class

Employment by enterprise size class

Value added by enterprise size class

Exports by enterprise size class 
The distribution of the business population by size provides basic information on the structure of the business sector. It is related to the distribution of businesses by activity sector and age and to the size of the internal market. It is of particular use, together with other business statistics by size class, to policy makers wishing to focus on the role in the economy of enterprises of different sizes.

\section{Definition}

An enterprise is a legal entity possessing the right to conduct business on its own, for example to enter into contracts, own property, incur liabilities for debts and establish bank accounts. It may consist of one or more local units or establishments corresponding to different production units situated in a geographically separate place and in which one or more persons work for the enterprise to which they belong.

The basis for size classification is the total number of persons employed, i.e. persons who worked in or for the concerned unit during the reference year.

Figures 3.1 and 3.2 show the number of enterprises in each size class, as a percentage of the total number of enterprises.

\section{Comparability}

All countries present information using the enterprise as the statistical unit except Japan, Korea and Mexico, which use establishments. As most enterprises in these countries consist of only one establishment, comparability issues are not expected to be significant.

Data for Japan and Korea do not include establishments with fewer than four and five persons employed, respectively. For the United States, employment in enterprises refers to the number of employees and not the number of persons employed.

The size-class breakdown 1-9, 10-19, 20-49, 50-249, 250+ provides for the best comparability given the varying data collection practices across countries. Some countries use different conventions: the size class "20-49" actually refers to "20-99" for the United States; the size class "50-249" refers to "50-199" for Australia, "100-499" for the United States; and the size class "250+" refers to "200+" for Australia, and "500+" for the United States.

Data cover market economy, excluding financial intermediation; for Japan they cover manufacturing sectors only. This may result in a lower proportion of micro-enterprises for these countries, since the average size of enterprises is typically lower in the services sector.

The reference year of the data is 2008; it is 2007 for France, Greece and Japan; 2006 for Australia and Korea; 2005 for Iceland; and 2003 for Mexico.

In Figure 3.1, the high share of enterprises with 1 to 9 persons employed does not allow to visually compare the shares of the various size classes above 10 persons employed. For this reason, a second figure is proposed, focusing on enterprises with more than 10 persons employed.

\section{Highlights}

The business population is composed, in any country, of a predominant number of micro-enterprises, i.e. firms with less than ten employees. In half of the OECD countries, micro-enterprises account for more than $90 \%$ of the total enterprises.

\section{Source/Online database}

OECD Structural and Demographic Business Statistics (SDBS) Database, http://dx.doi.org/10.1787/sdbs-data-en.

\section{For further reading}

OECD (2010), Structural and Demographic Business Statistics, OECD Publishing,

http://dx.doi.org/10.1787/9789264072886-en.

Ahmad N. (2007), The OECD's Business Statistics Database and Publication, Paper presented at the Structural Business Statistics Expert Meeting, Paris, 10-11 May 2007, www.oecd.org/dataoecd/59/34/38516035.pdf.

Information on data for Israel:

http://dx.doi.org/10.1787/888932315602. 


\section{STRUCTURAL INDICATORS ON THE ENTERPRISE POPULATION}

Figure 3.1 Enterprises by size class, 2008 or latest available year Percentage

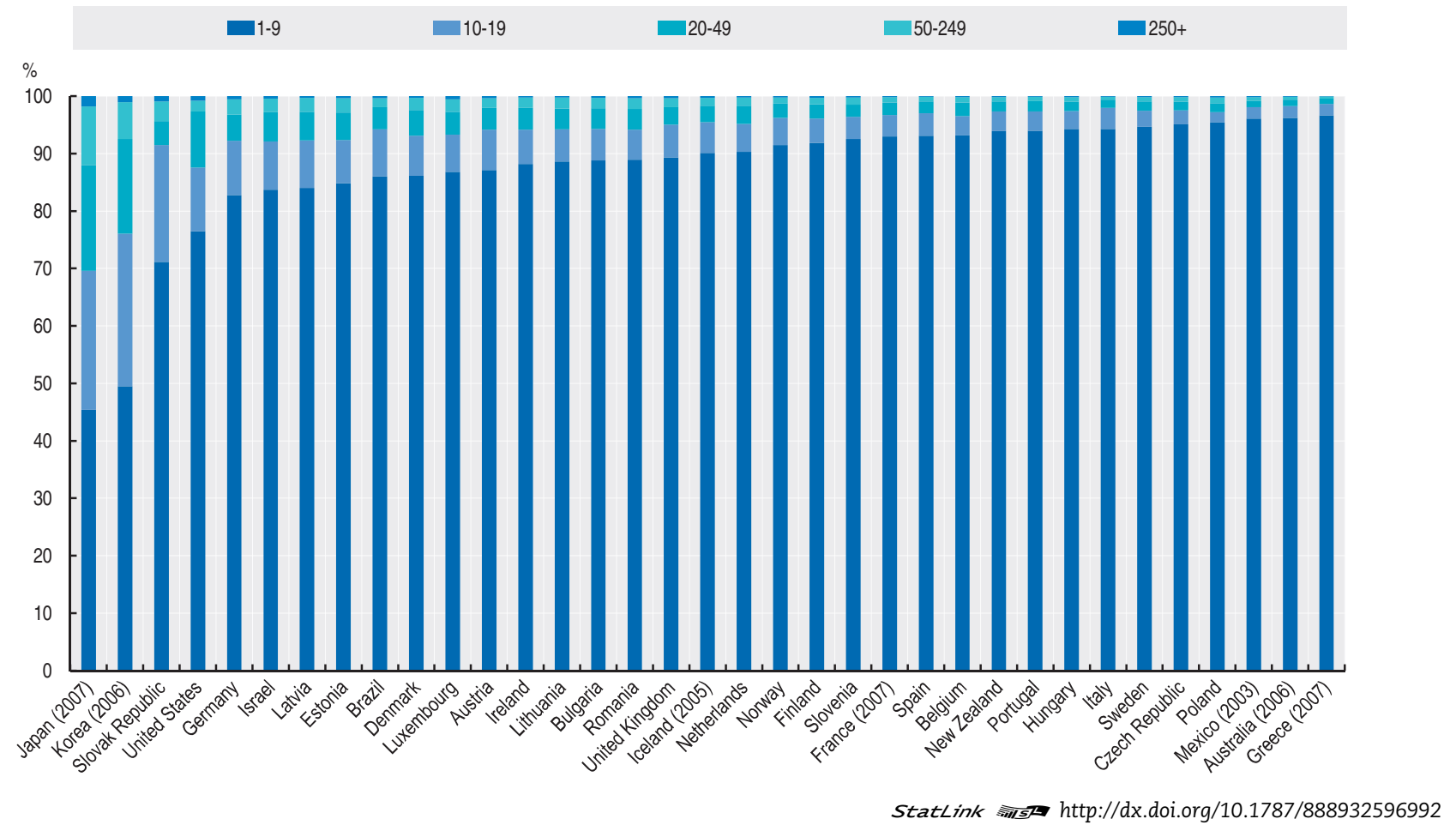

Figure 3.2 Enterprises with 10 persons engaged or more, 2008 or latest available year Percentage

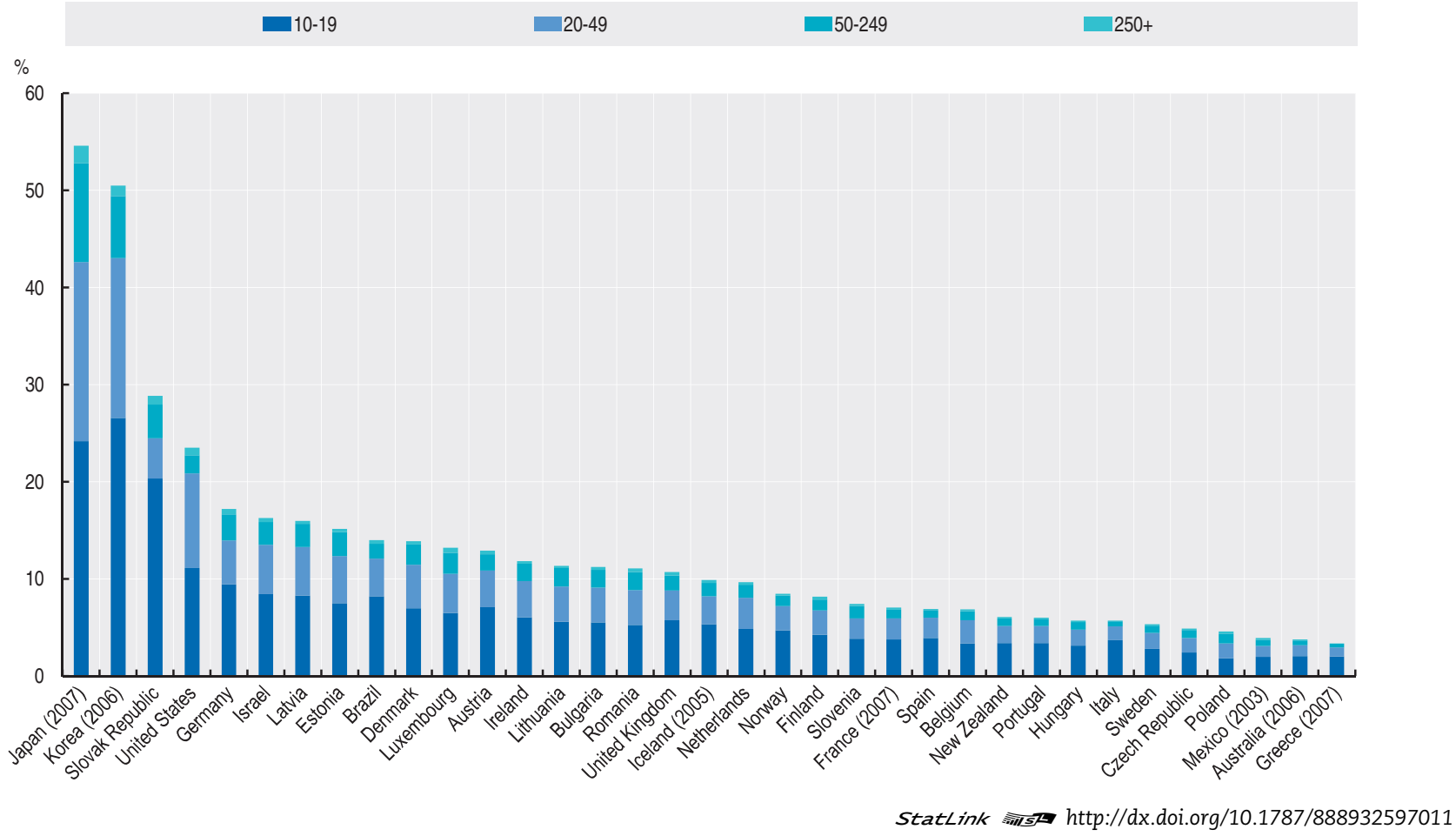


The breakdown of employment by size class describes how total employment is distributed among enterprises of different sizes. It provides important information on the ability of firms of various sizes to foster employment.

\section{Definition}

The total number of persons employed is defined as the total number of persons who worked in or for the concerned unit during the reference year.

Total employment excludes directors of incorporated enterprises and members of shareholders' commit tees who are paid solely for their attendance at meetings, labour force made available to the concerned unit by other units and charged for, persons carrying out repair and maintenance work in the unit on the behalf of other units, and home workers. It also excludes persons on indefinite leave, military leave or those whose only remuneration from the enterprise is by way of a pension.

Unless otherwise stated, data are expressed as a percentage of the total number of persons employed in market industry. Total employment by country is shown in Table 3.1.

\section{Comparability}

Data for all countries refer to the number of persons employed, with the exception of Brazil, New Zealand and the United States for which it refers to the number of employees.

All countries present information using the enterprise as the statistical unit except Japan, Korea and Mexico, which use establishments.

Data for Japan and Korea do not include establishments with fewer than four and five persons employed respectively.

The size-class breakdown used (1-9, 10-19, 20-49, 50-249, $250+)$ provides for the best comparability given the varying data collection practices across countries. Some countries use different conventions: the size class "1-9" actually refers to "1-19" for Australia; the size class "20-49" refers to "20-99" for the United States; the size class "50-249" refers to "20-199" for Australia, and "100-499" for the United States; and the size class "250+" refers to "200+" for Australia, and " $500+$ " for the United States.

Data cover the market economy, excluding financial intermediation; for Israel, Japan and Korea, they cover manufacturing sectors only. This may result in a lower proportion of employment in micro-enterprises for these countries, since the average size of enterprises is typically lower in the services sector.

The reference year of the data is 2008, with the exception of Greece, Israel and Japan (2007), Korea (2006) and Mexico (2003).

\section{Highlights}

There are significant variations across countries concerning the distribution of employment among enterprises of different sizes. In Greece, Italy, and Mexico more than $40 \%$ of employment is in enterprises with less than ten persons employed, while the same category of firms accounts for less than $20 \%$ of total employment in Denmark, Germany, Israel, the Slovak Republic and the United Kingdom.

\section{Source/online database}

OECD Structural and Demographic Business Statistics (SDBS) Database, http://dx.doi.org/10.1787/sdbs-data-en.

\section{For further reading}

Ahmad N. (2007), The OECD's Business Statistics Database and Publication, Paper presented at the Structural Business Statistics Expert Meeting, Paris, 10-11 May 2007, www.oecd.org/dataoecd/59/34/38516035.pdf.

OECD (2010), Structural and Demographic Business Statistics, OECD Publishing, http://dx.doi.org/10.1787/9789264072886-en.

Information on data for Israel: http://dx.doi.org/10.1787/888932315602. 


\section{STRUCTURAL INDICATORS ON THE ENTERPRISE POPULATION}

Figure 3.3 Employment by enterprise size class, 2008 or latest available year Percentage

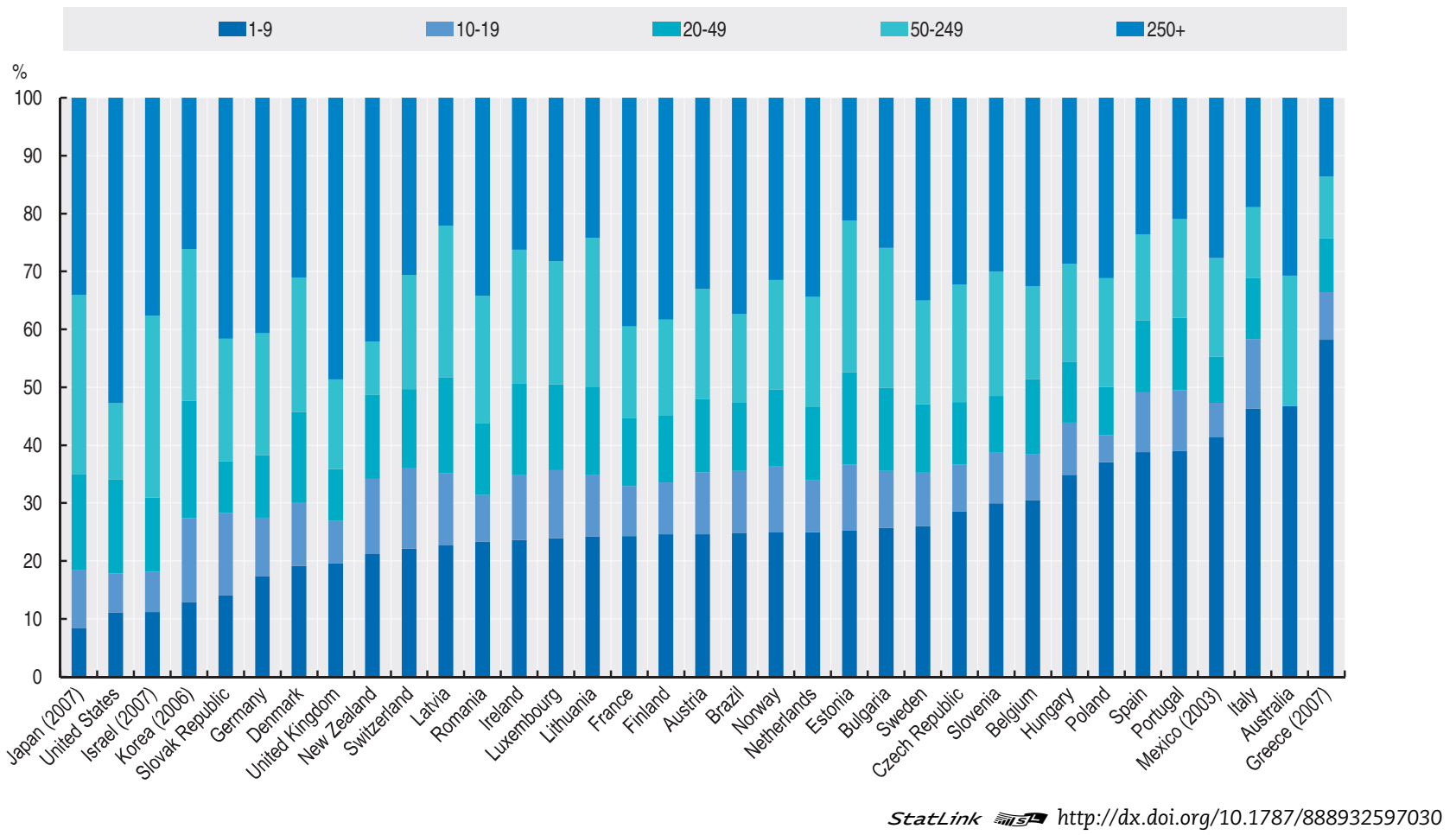

Table 3.1 Number of persons employed, 2008 or latest available year

\begin{tabular}{lr|lr|lr|lc}
\hline Country & Employment & Country & Employment & Country & Employment & Country & Employment \\
\hline Japan (manufacturing, 2007) & 8621393 & Switzerland & 985243 & Brazil (number of employees) & 24337688 & Hungary & 2635679 \\
United States (number of employees) & 71505608 & Latvia & 677819 & Norway & 1482961 & Poland & 8667915 \\
Israel (manufacturing, 2007) & 360744 & Romania & 4413763 & Netherlands & 5554122 & Spain & 13460293 \\
Korea (manufacturing, 2006) & 2910935 & Ireland & 1207850 & Estonia & 432927 & Portugal & 3297018 \\
Slovak Republic & 1088125 & Luxembourg & 171942 & Bulgaria & 2055506 & Mexico (2003) & 13110232 \\
Germany & 18252505 & Lithuania & 989202 & Sweden & 2960552 & Italy & 15814676 \\
Denmark & 1642273 & France & 15104252 & Czech Republic & 3653435 & Australia & 7603693 \\
United Kingdom & 18426683 & Finland & 1443436 & Slovenia & 618563 & Greece (2007) & 2600028 \\
New Zealand (number of employees) & 1215528 & Austria & 2588941 & Belgium & 2493628 & \\
\hline
\end{tabular}

Note: The reference year of the data is 2008, with the exception of Greece, Israel and Japan (2007), Korea (2006) and Mexico (2003).

Data cover the market economy, excluding financial intermediation; for Israel, Japan and Korea, they cover manufacturing sectors only.

The statistical data for Israel are supplied by and under the responsibility of the relevant Israeli authorities. The use of such data by the OECD is without prejudice to the status of the Golan Heights, East Jerusalem and Israeli settlements in the West Bank under the terms of international law. 
Value added by enterprise size class describes the contribution of enterprises of different sizes to total value added of the business sector. This indicator contributes to improve understanding of the relative importance of different size classes in generating value added in a country's economy.

\section{Definitions}

Value added corresponds to the difference between production and intermediate consumption, where total intermediate consumption should always be valued at purchasers' prices. Depending on the valuation of production and on the treatment applied to indirect taxes and subsidies, the valuation of value added is either a basic prices, producers' prices on factor costs.

Data in this section present the value added in each size class as a percentage of the value added of all enterprises.

\section{Comparability}

Data refer to value added at factor costs in the EU countries and value added at basic prices for Australia, Japan and Korea. All countries present information using the enterprise as the statistical unit except Japan, Korea and Mexico, which use establishments.

Data for Japan and Korea do not include establishments with fewer than four and five persons employed respectively.

The size class breakdown used provides for the best comparability across countries given the varying data collection practices across countries. Some countries use different conventions. For Australia, data shown for "1-9" actually refer to "1-19", data shown for "50-249" refer to "20-199", data shown for "250+" actually refer to "200+".

Data cover the market economy, excluding financial intermediation. They cover only manufacturing sectors for Israel and Japan.

The reference year of the data is 2008; it is 2007 for France, Greece, Israel and Japan; and 2003 for Mexico.

\section{Highlights}

In most countries, enterprises with more than 250 persons employed account for a considerable part of the value added of the business sector, despite representing a small share of the business population. In Brazil, Israel and the United Kingdom the share of value added of large enterprises exceeds $50 \%$.

\section{Source/Online database}

OECD Structural and Demographic Business Statistics (SDBS) Database, http://dx.doi.org/10.1787/sdbs-data-en.

\section{For further reading}

OECD (2010), Structural and Demographic Business Statistics, OECD Publishing, http://dx.doi.org/10.1787/9789264072886-en.

Information on data for Israel:

http://dx.doi.org/10.1787/888932315602. 
Figure 3.4 Value added by enterprise size class, 2008 or latest available year Percentage

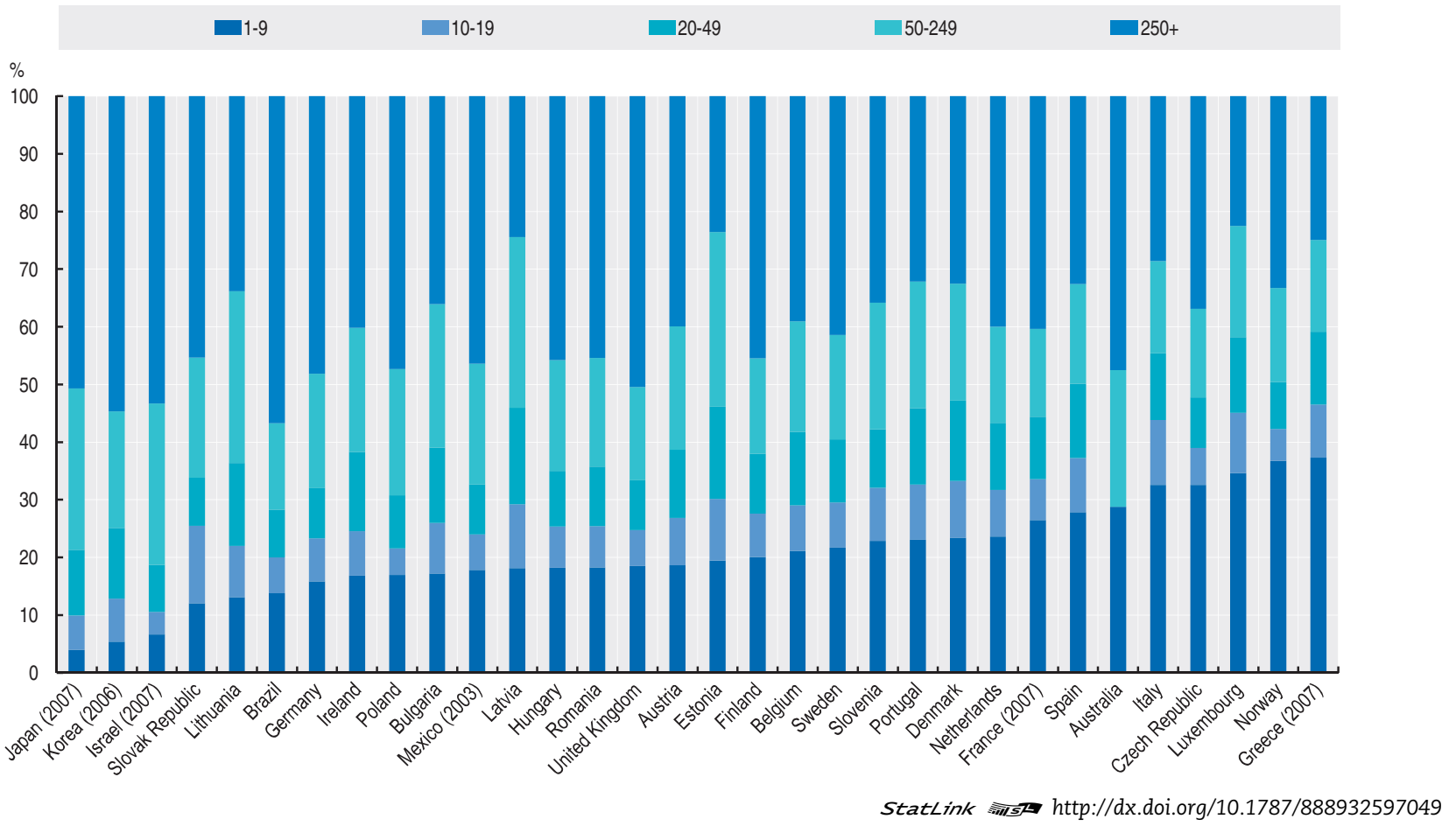

Table 3.2 Value added by enterprise size class, 2008 or latest available year

Percentage

\begin{tabular}{|c|c|c|c|c|c|}
\hline & $1-9$ & $10-19$ & $20-49$ & $50-249$ & $250+$ \\
\hline Japan (2007) & 3.98 & 5.97 & 11.36 & 28.01 & 50.68 \\
\hline Korea (2006) & 5.40 & 7.45 & 12.26 & 20.22 & 54.68 \\
\hline Israel (2007) & 6.64 & 3.95 & 8.10 & 28.01 & 53.31 \\
\hline Slovak Republic & 12.05 & 13.46 & 8.30 & 20.83 & 45.36 \\
\hline Lithuania & 13.09 & 8.88 & 14.39 & 29.79 & 33.85 \\
\hline Brazil & 13.80 & 6.21 & 8.27 & 15.02 & 56.71 \\
\hline Germany & 15.86 & 7.48 & 8.66 & 19.85 & 48.15 \\
\hline Ireland & 16.83 & 7.69 & 13.77 & 21.50 & 40.20 \\
\hline Poland & 16.97 & 4.60 & 9.20 & 21.88 & 47.36 \\
\hline Bulgaria & 17.18 & 8.78 & 13.09 & 24.90 & 36.05 \\
\hline Mexico (2003) & 17.85 & 6.16 & 8.65 & 20.94 & 46.39 \\
\hline Latvia & 18.17 & 11.08 & 16.74 & 29.60 & 24.43 \\
\hline Hungary & 18.20 & 7.18 & 9.65 & 19.20 & 45.76 \\
\hline Romania & 18.26 & 7.18 & 10.31 & 18.85 & 45.40 \\
\hline United Kingdom & 18.49 & 6.26 & 8.62 & 16.22 & 50.41 \\
\hline Austria & 18.64 & 8.21 & 11.81 & 21.42 & 39.92 \\
\hline Estonia & 19.48 & 10.65 & 15.99 & 30.29 & 23.59 \\
\hline Finland & 20.08 & 7.50 & 10.42 & 16.53 & 45.48 \\
\hline Belgium & 21.14 & 7.89 & 12.79 & 19.15 & 39.04 \\
\hline Sweden & 21.68 & 7.87 & 10.95 & 18.08 & 41.43 \\
\hline Slovenia & 22.85 & 9.24 & 10.14 & 21.97 & 35.80 \\
\hline Portugal & 23.08 & 9.55 & 13.24 & 22.00 & 32.13 \\
\hline Denmark & 23.35 & 9.91 & 13.93 & 20.28 & 32.53 \\
\hline Netherlands & 23.62 & 8.11 & 11.61 & 16.69 & 39.97 \\
\hline France (2007) & 26.48 & 7.07 & 10.82 & 15.29 & 40.34 \\
\hline Spain & 27.82 & 9.44 & 12.87 & 17.31 & 32.55 \\
\hline Australia & 28.76 & & & 23.70 & 47.55 \\
\hline Italy & 32.55 & 11.29 & 11.57 & 15.96 & 28.63 \\
\hline Czech Republic & 32.56 & 6.44 & 8.76 & 15.35 & 36.90 \\
\hline Luxembourg & 34.62 & 10.48 & 13.13 & 19.29 & 22.48 \\
\hline Norway & 36.73 & 5.58 & 8.15 & 16.27 & 33.27 \\
\hline Greece (2007) & 37.29 & 9.20 & 12.64 & 15.92 & 24.95 \\
\hline
\end{tabular}

Note: The reference year of the data is 2008; it is 2007 for France, Greece, Israel and Japan; 2006 for Korea and 2003 for Mexico.

Data cover the market economy, excluding financial intermediation. They cover only manufacturing sectors for Israel and Japan.

The statistical data for Israel are supplied by and under the responsibility of the relevant Israeli authorities. The use of such data by the OECD is without prejudice to the status of the Golan Heights, East Jerusalem and Israeli settlements in the West Bank under the terms of international law. StatLink Ails $h t t p: / / d x . d o i . o r g / 10.1787 / 888932598094$ 
Exports by enterprise size class describe the contribution of enterprises of different sizes to total exports. This indicator provides information on the importance of small and larger firms in shaping a country's position in the global economy.

\section{Definitions}

Exports refer to the outward flows of goods subtracted from the stock of material resources of a country. Goods simply being transported through a country (goods in transit) or temporarily admitted or withdrawn (except for goods for inward or outward processing) do not add to or subtract from the stock of material resources of a country and are not included in the international merchandise trade statistics.

Figure 3.5 shows the merchandise exports of enterprises in each size class as a percentage of exports of all enterprises. For EU countries the population of the numerator and denominator refers only to enterprises exporting extra-EU.

Figure 3.6 presents the total number of exporters by size class as a percentage of the total number of enterprises in the corresponding size class. The population of the numerator refers only to enterprises exporting extra-EU.

\section{Comparability}

Trade statistics by enterprise characteristics are developed by linking trade registers and business registers.

The main comparability issue that arises is due to differences in the trade system used by countries to compile international merchandise trade statistics, i.e. general trade system and special trade system. The general trade system is recommended by the International Merchandise Trade Statistics (IMTS) manual and includes all goods that cross the national frontier including goods that are imported into and exported from custom-bonded warehouses and free zones. The general trade system is in use "when the statistical territory of a country coincides with its economic territory so that imports include all goods entering the economic territory of a compiling country and exports include all goods leaving the economic territory of a compiling country". The special trade system is recommended by Eurostat and covers goods that cross the customs frontier plus goods that are imported into and exported from custom-bonded areas. The special trade system is in use when the statistical territory comprises only a particular part of the economic territory.

For EU Member States, data on intra-EU and extra-EU exports are treated separately, owing to different data col- lection systems and thresholds. Total exports are compiled by adding intra-EU and extra-EU exports.

An additional issue concerns the differences in the statistical unit used for the collection of raw data. In European countries the enterprise is used as the statistical unit, while the establishment is used in Canada and the United States.

Data are presented for four enterprise size classes: from 0 to 9 employees; between 10 and 49 employees; between 50 and 249 employees; and equal to or more than 250 employees. Enterprises whose number of employees is not available are grouped in the category "unknown".

For Figure 3.5, the reference year is 2009, except for Israel (2008) and Norway (2007). Data cover ISIC Rev.4 sectors: industry, wholesale, retail trade and repair, and other services, excluding financial services and hotel/restaurants. For Israel and Norway data are in ISIC Rev. 3.

For Figure 3.6, the reference year is 2008. Data cover ISIC Rev.4 sectors: industry, wholesale, retail trade and repair, and other services, excluding financial services and hotel/ restaurants.

\section{Highlights}

In the majority of countries, more than $50 \%$ of total exports are accounted for by the enterprises with 250 employees or more. Moreover, the propensity to export increases with the enterprise size: across countries, less than $5 \%$ of micro-enterprises are exporters while typically half of large enterprises have an export activity.

\section{Source/online databases}

\section{OECD Trade by Enterprise Characteristics Database (TEC).}

\section{For further reading}

Eurostat (2007), “External Trade by Enterprise Characteristics", Luxembourg.

OECD (2011), "Selling to Foreign Markets: a Portrait of OECD Exporters", Statistics Brief No. 16, ww.oecd.org/dataoecd/28/27/47014723.pdf.

OECD (2010), Structural and Demographic Business Statistics, OECD Publishing, http://dx.doi.org/10.1787/9789264072886-en.

United Nations (2011), International Merchandise Trade Statistics: Concept and Definitions 2010 (IMTS 2010), http://unstats.un.org/unsd/trade/EG-IMTS/ IMTS\%202010\%20\%28English\%29.pdf. 


\section{STRUCTURAL INDICATORS ON THE ENTERPRISE POPULATION}

Figure 3.5 Exports by enterprise size class, 2009 or latest available year Percentage of exports of all enterprises

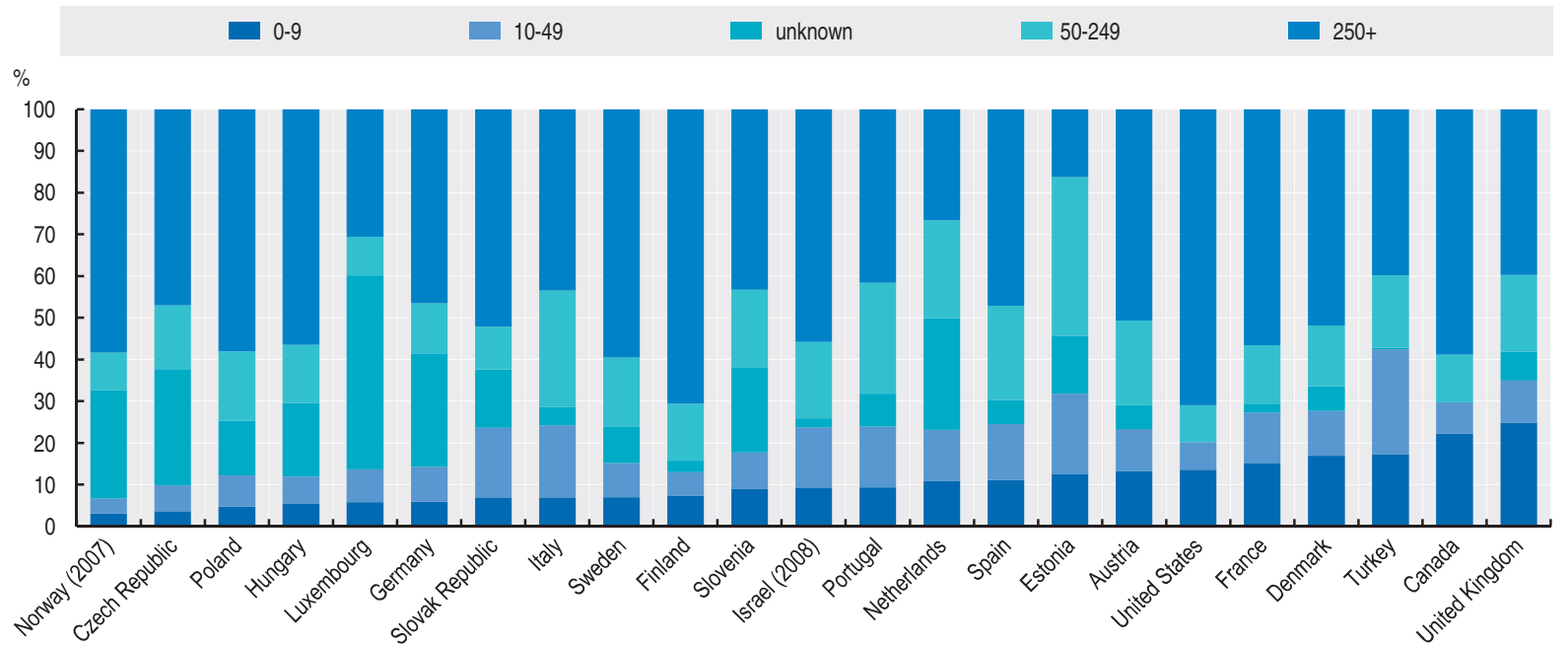

StatLink (ins $h$ Lttp://dx.doi.org/10.1787/888932597068

Figure 3.6 Export propensity by enterprise size class, 2008

Percentage of exporting enterprises on total enterprises in the corresponding size class

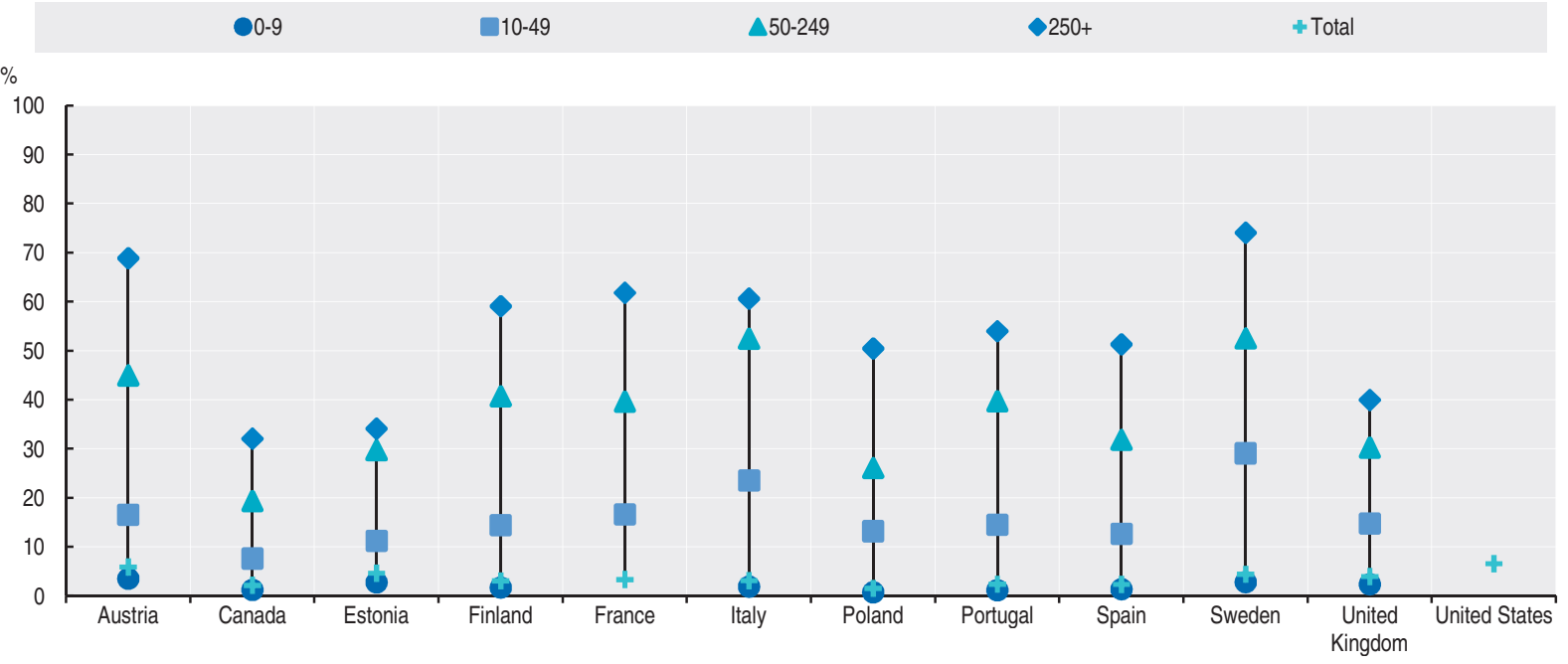

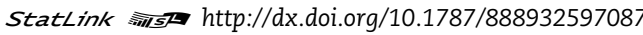





\section{ENTERPRISE BIRTH, DEATH AND SURVIVAL}

Birth rate of employer enterprises

Death rate of employer enterprises

Churn rate of employer enterprises

Survival rate of employer enterprises 
The birth of new enterprises is a key indicator of business dynamism. It reflects an important dimension of entrepreneurship in a country, namely the capacity to start up entirely new businesses.

Employer enterprises are economically more relevant than non-employer firms and more closely related to the notion of entrepreneurship as a driver of job creation and innovation.

\section{Definitions}

An employer enterprise birth refers to the birth of an enterprise with at least one employee. The population of employer enterprise births consists first of "new" enterprise births, i.e. new enterprises reporting at least one employee in the birth year; and second, enterprises that existed before the year under consideration but were then below the threshold of one employee, and that reported one or more employees in the current, i.e. birth, year.

Employer enterprise births do not include entries into the population due to: mergers, break-ups, split-off or restructuring of a set of enterprises. They also exclude entries into a sub-population resulting only from a change of activity.

The employer enterprise birth rate corresponds to the number of births of employer enterprises as a percentage of the population of active enterprises with at least one employee.

Figure 4.2 shows for each country the deviations from the country's average over the period 2005-09 (or latest available year).

\section{Comparability}

"Employer" indicators are found to be more relevant for international comparisons than indicators covering all enterprises, as the latter are sensitive to the coverage of business registers. In many countries, the main sources of data used in business registers are administrative tax and employment registers, meaning that often only businesses above a certain turnover and/or employment threshold are captured. An economy with relatively high thresholds would therefore be expected to have lower birth statistics than similar economies with lower thresholds. An additional complication relates to changes in thresholds over time. Monetary-based thresholds change over time in response to e.g. inflation and fiscal policy, both of which can be expected to affect comparisons of birth rates across countries and over time. The use of the one-employee thresholds improves comparability, as it excludes very small units, which are the most subject to threshold variations.

The concept of employer enterprise birth is itself not without problems. Many countries have sizeable populations of self-employed. If a country creates incentives for the selfemployed to become employees of their own company, the total number of employer enterprise births will increase. This can distort comparisons over time and across countries, even if from an economic and entrepreneurial perspective little has changed.

Data presented refer to the whole population of employer enterprises, with the exception of Canada, for which data refer to employer enterprises with less than 250 employees. Data are classified according to ISIC Revision 4 for all countries except Canada, Israel, Mexico and the United States for which data are in ISIC Revision 3. Data for Mexico are based on the 2009 Economic Census.

\section{Highlights}

Birth rates of employer enterprises are higher in the services sector than in manufacturing. The newly created firms employ typically one to four employees, while few start with more than 10 employees.

The effects of the global crisis are noticeable: between 2007 and 2009 birth rates decreased in all countries where data are available. Only in Austria the birth rate in 2009 was higher than in 2008 although still below the 2007 level.

\section{Source/online database}

OECD Structural and Demographic Business Statistics (SDBS) Database, http://dx.doi.org/10.1787/sdbs-data-en.

\section{For further reading}

Ahmad, N. (2006), “A Proposed Framework For business Demography Statistics”, OECD Statistics Working Papers, 2006/3, OECD Publishing, Paris, http://dx.doi.org/10.1787/145777872685.

Eurostat/OECD (2007), Eurostat-OECD Manual on Business Demography Statistics, OECD Publishing.

OECD (2010), Structural and Demographic Business Statistics, OECD Publishing, http://dx.doi.org/10.1787/9789264072886-en.

Information on data for Israel:

http://dx.doi.org/10.1787/888932315602. 


\section{ENTERPRISE BIRTH, DEATH AND SURVIVAL}

Birth rate of employer enterprises

A corrigendum has been issued for this page. See http://www.oecd.org/about/publishing/Corrigendum_EAG.pdf Figure 4.1 Employer enterprise birth rate, total economy

\section{Percentage}

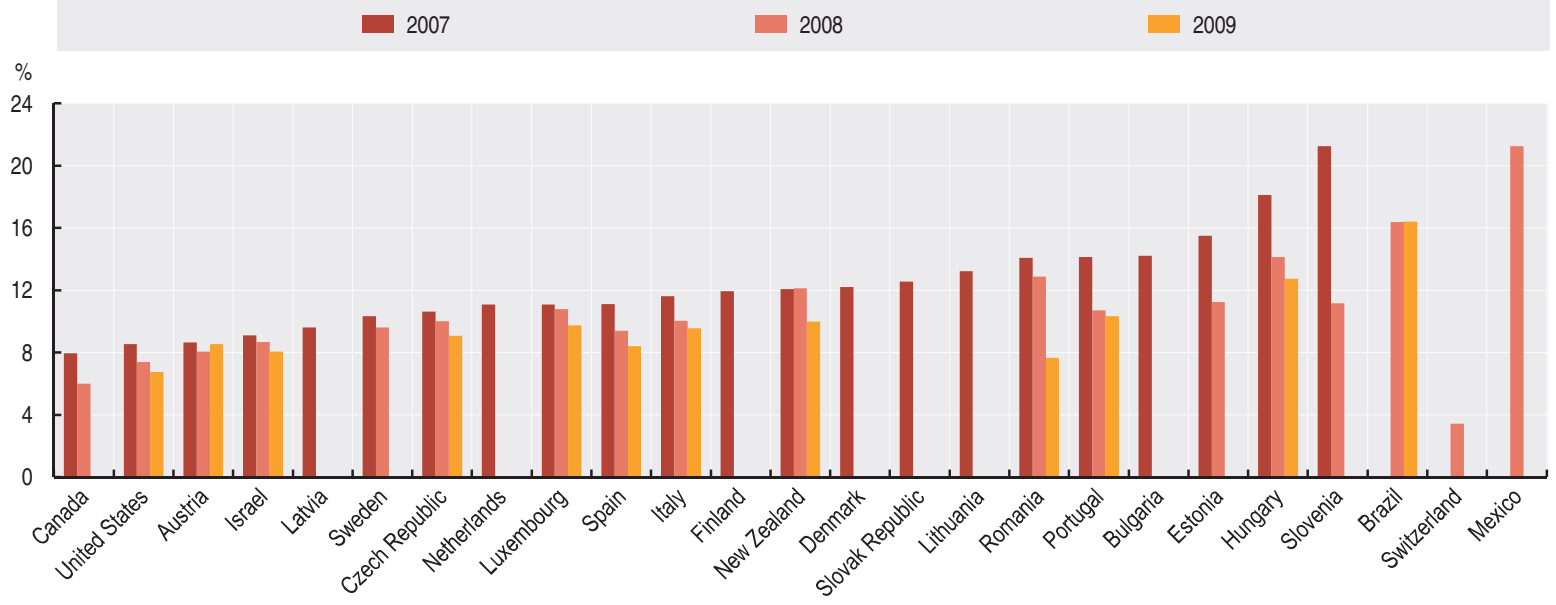

StatLink Nilst $h t t p: / / d x . d o i . o r g / 10.1787 / 888932597106$

Figure 4.2 Trends in employer enterprise birth rate by sector

Deviation from country average, percentage

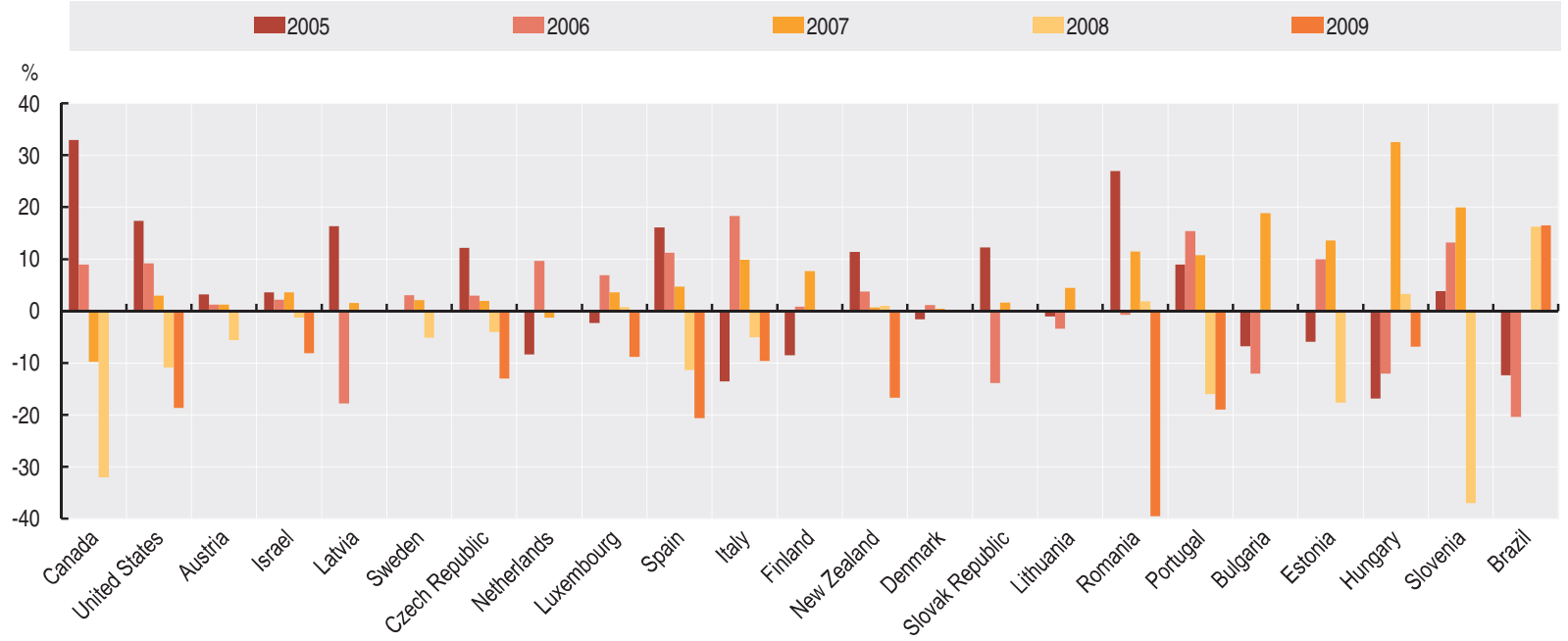

StatLink Nilst $h t t p: / / d x . d o i . o r g / 10.1787 / 888932597125$

Figure 4.3 Employer enterprise birth rate by sector, 2008 Percentage

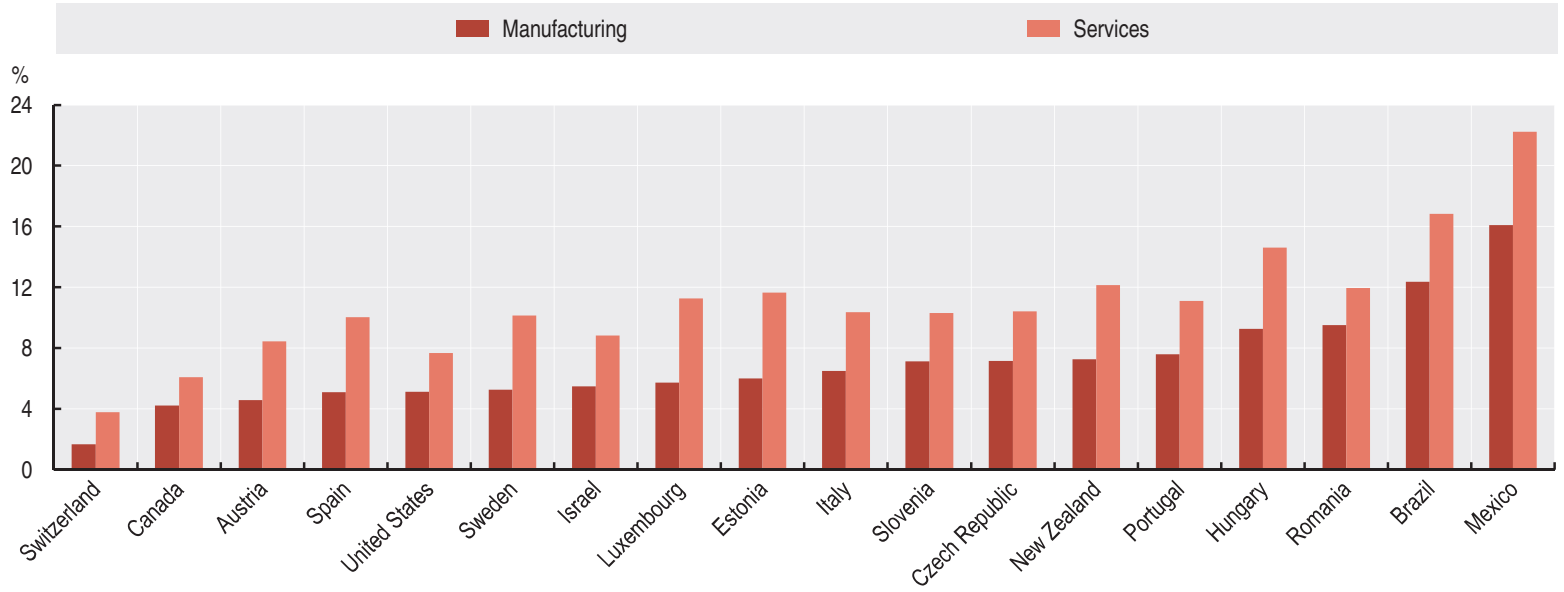

StatLink Aiाst http://dx.doi.org/10.1787/888932597144 


\section{ENTERPRISE BIRTH, DEATH AND SURVIVAL}

\section{Birth rate of employer enterprises}

Figure 4.4 Employer enterprise birth rate by size class, manufacturing, 2008 Percentage

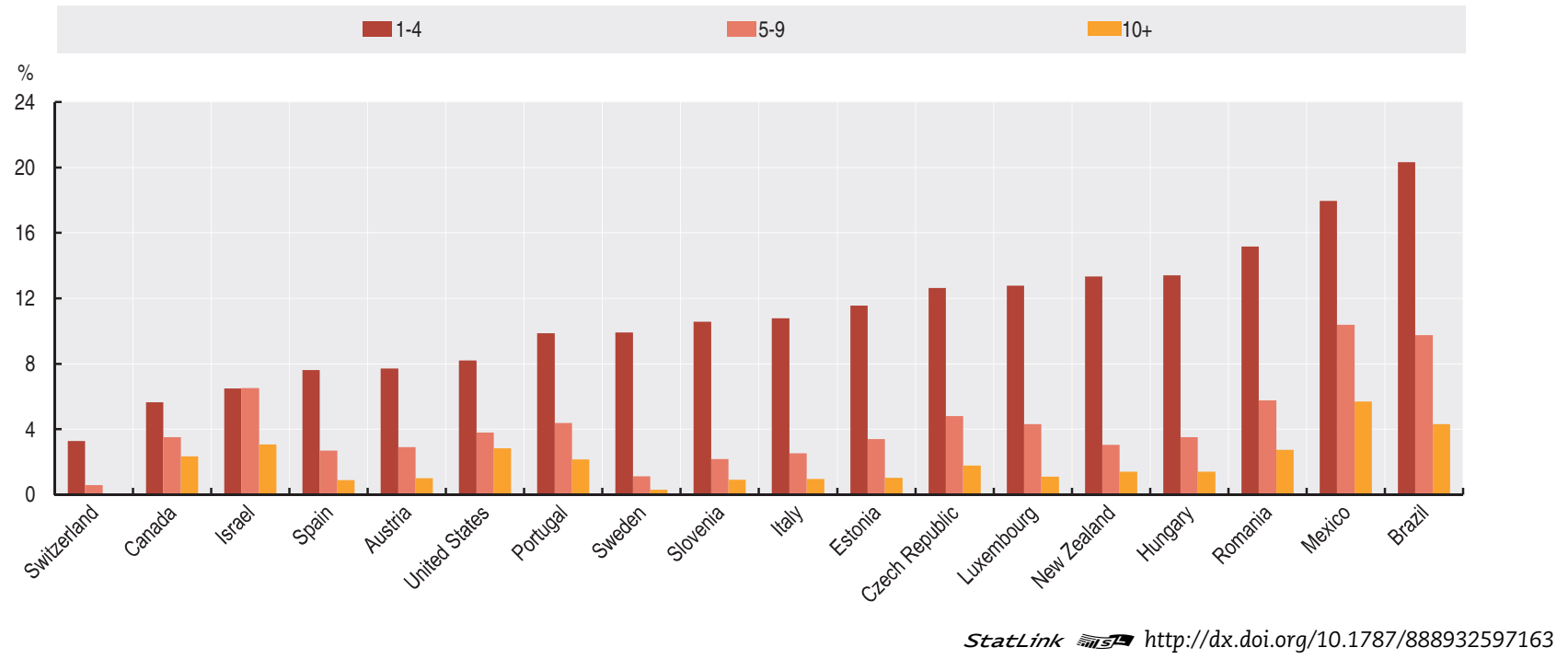

Figure 4.5 Employer enterprise birth rate by size class, services, 2008 Percentage

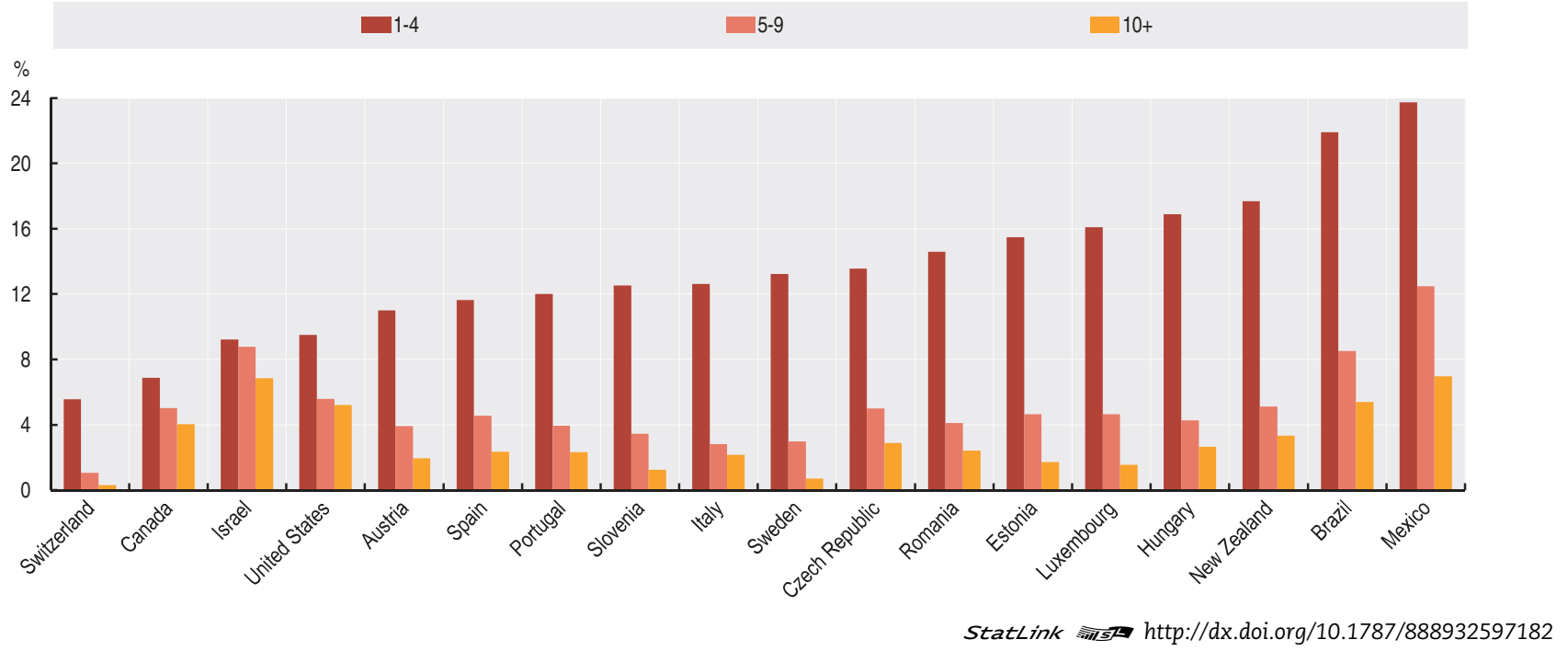




\section{ENTERPRISE BIRTH, DEATH AND SURVIVAL}

Birth rate of employer enterprises

Figure 4.6 Employer enterprise birth rate in various industries, 2008

Percentage
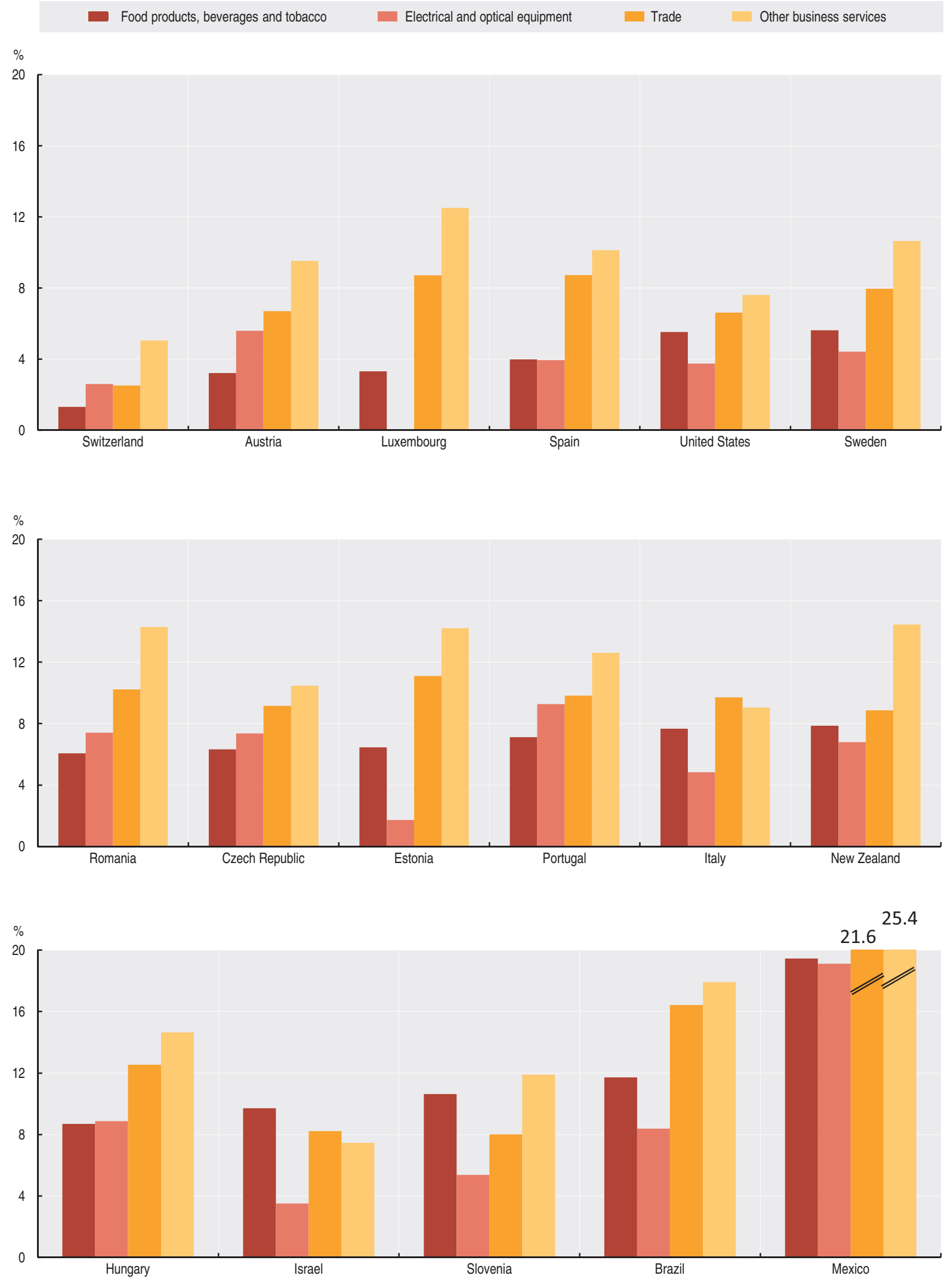

StatLink AाIst http://dx.doi.org/10.1787/888932597201 


\section{Death rate of employer enterprises}

The death of enterprises is an integral part of the phenomenon of entrepreneurship. Knowing the percentage of firms that die in a given year and comparing it over time and across countries is of high interest to policy makers to understand, for example, the impact of structural and cyclical effects on the disappearance of enterprises.

\section{Definitions}

An employer enterprise death occurs either as the death of an enterprise with at least one employee in the year of death or the move of an enterprise below the threshold of one employee for at least two years.

Deaths do not include exits from the population due to mergers, take-overs, break-ups and restructuring of a set of enterprises. They also exclude exits from a sub-population resulting only from a change of activity.

The employer enterprise death rate corresponds to the number of deaths of employer enterprises as a percentage of the population of active enterprises with at least one employee.

Figure 4.2 shows for each country the deviations from the country's average over the period 2005-09 (or latest available year).

\section{Comparability}

Compared to data on births of employer enterprises, there is an additional time lag in data collection of enterprise deaths linked to the process of confirmation of the event: it has to be checked that the enterprise has not been reactivated (or had no employees) in the following two years. Hence, information on death rates presented in this publication refer mainly to 2006, and not to 2007 as for all other indicators.

"Employer" indicators are found to be more relevant for international comparisons than indicators covering all enterprises, as the latter are sensitive to the coverage of business registers. In many countries, the main sources of data used in business registers are administrative tax and employment registers, meaning that often only business above a certain turnover and/or employment threshold are captured. An additional complication in this regard relates to changes in thresholds over time. Monetary-based thresholds change over time in response to e.g. inflation and fiscal policy, both of which can be expected to affect comparisons of death rates across countries and over time. The use of the one-employee thresholds improves comparability, as it excludes very small units, which are the most subject to threshold variations.

Data refer to the whole population of employer enterprises, with the exception of Canada, for which data refer to employer enterprises with less than 250 employees.

Data are classified according to ISIC Revision 4 for all countries except Canada, Israel and the United States for which data are in ISIC Revision 3.

\section{Highlights}

In all countries, the death rates of employer enterprises in the services sector are consistently higher than the corresponding rates in the manufacturing sector. In several countries the death rate of employer enterprises increased already in 2007 at the beginning of the global crisis and in 2008. Very small firms, with one to four employees, have the highest death rates compared to firms in the other size classes. With few exceptions, trade and other business services are the sectors where the death rates are higher.

\section{Source/Online database}

OECD Structural and Demographic Business Statistics (SDBS) Database, http://dx.doi.org/10.1787/sdbs-data-en.

\section{For further reading}

Ahmad, N. (2006), “A Proposed Framework For business Demography Statistics”, OECD Statistics Working Papers, 2006/3, OECD Publishing, Paris, http://dx.doi.org/10.1787/1457778726853.

Eurostat/OECD (2007), Eurostat-OECD Manual on Business Demography Statistics, OECD Publishing.

OECD (2010), "Structural and Demographic Business Statistics", OECD Publishing, http://dx.doi.org/10.1787/9789264072886-en.

Information on data for Israel:

http://dx.doi.org/10.1787/888932315602. 


\section{ENTERPRISE BIRTH, DEATH AND SURVIVAL}

Death rate of employer enterprises

Figure 4.7 Employer enterprise death rate, total economy Percentage

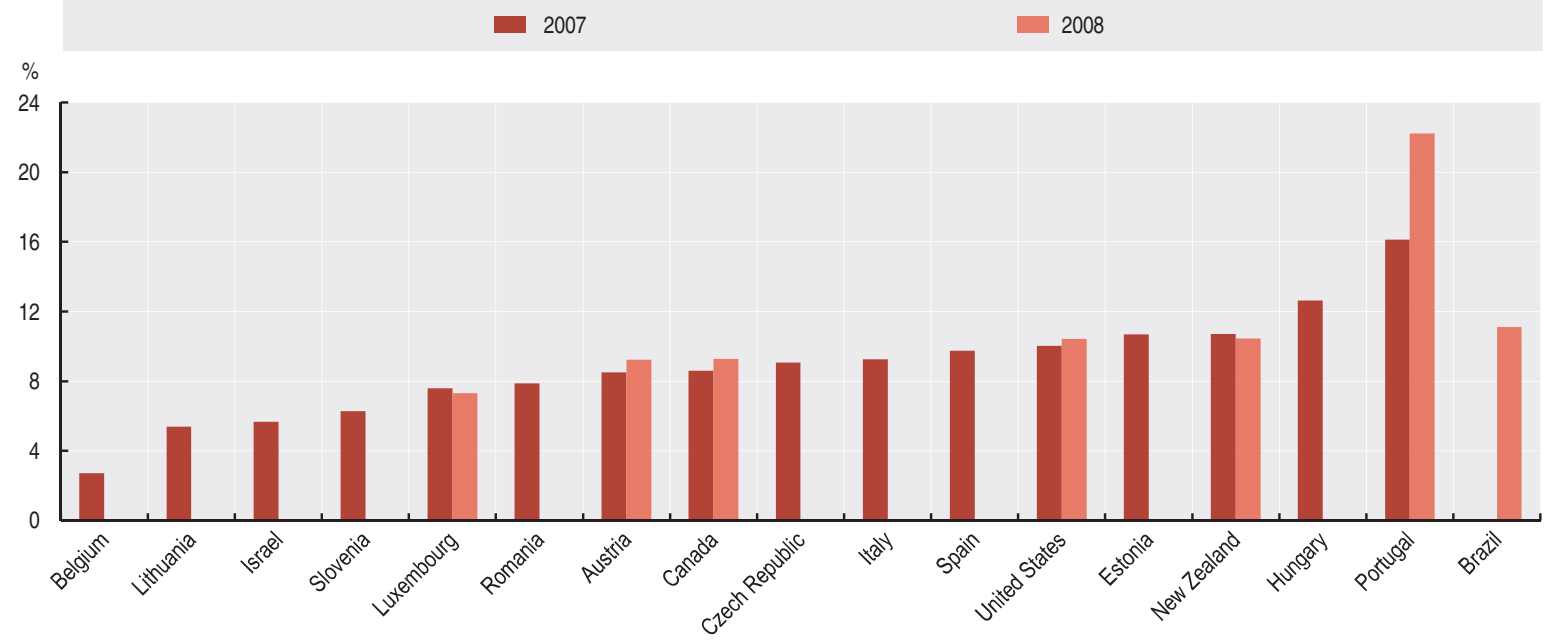

StatLink Nilst $h t t p: / / d x . d o i . o r g / 10.1787 / 888932597220$ Figure 4.8 Trends in employer enterprise death rate

Deviation from country average, percentage

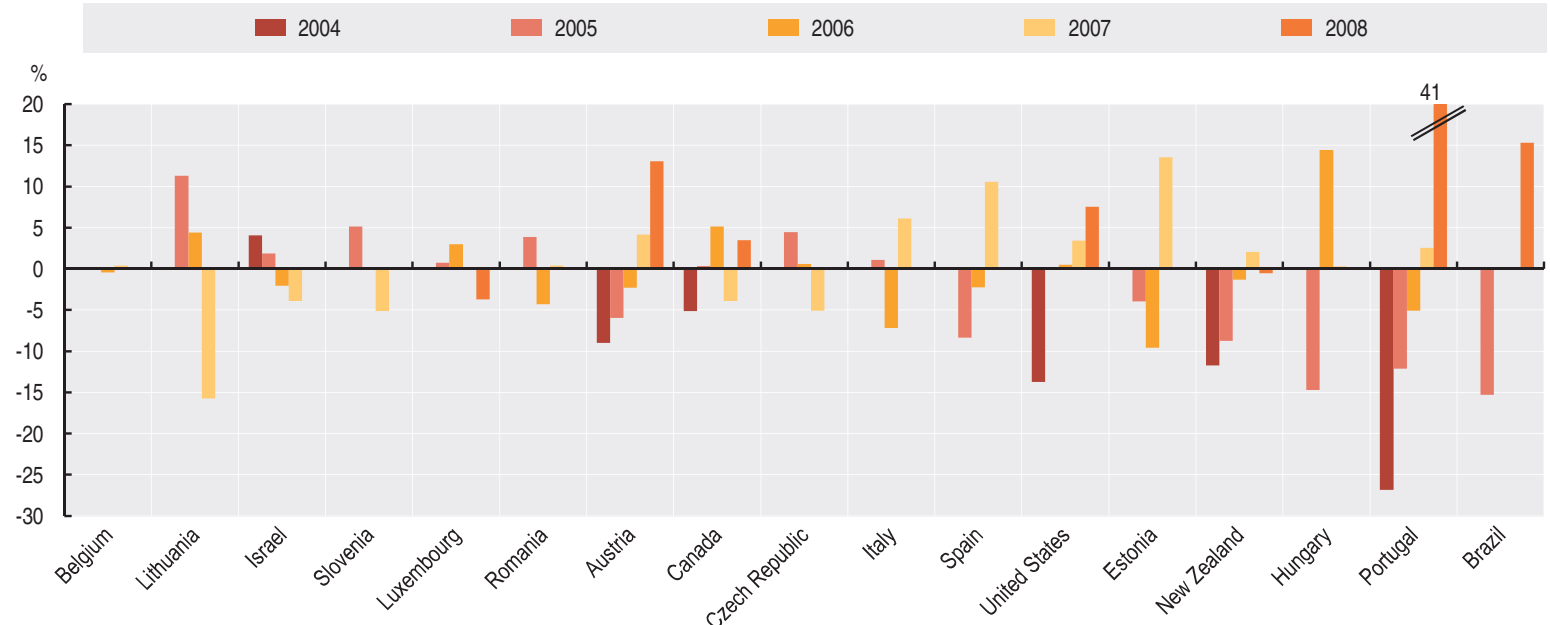

StatLink ताIs $h$ ttp://dx.doi.org/10.1787/888932597239

Figure 4.9 Employer enterprise death rates by sector, 2007 (2008 in insert)

Percentage

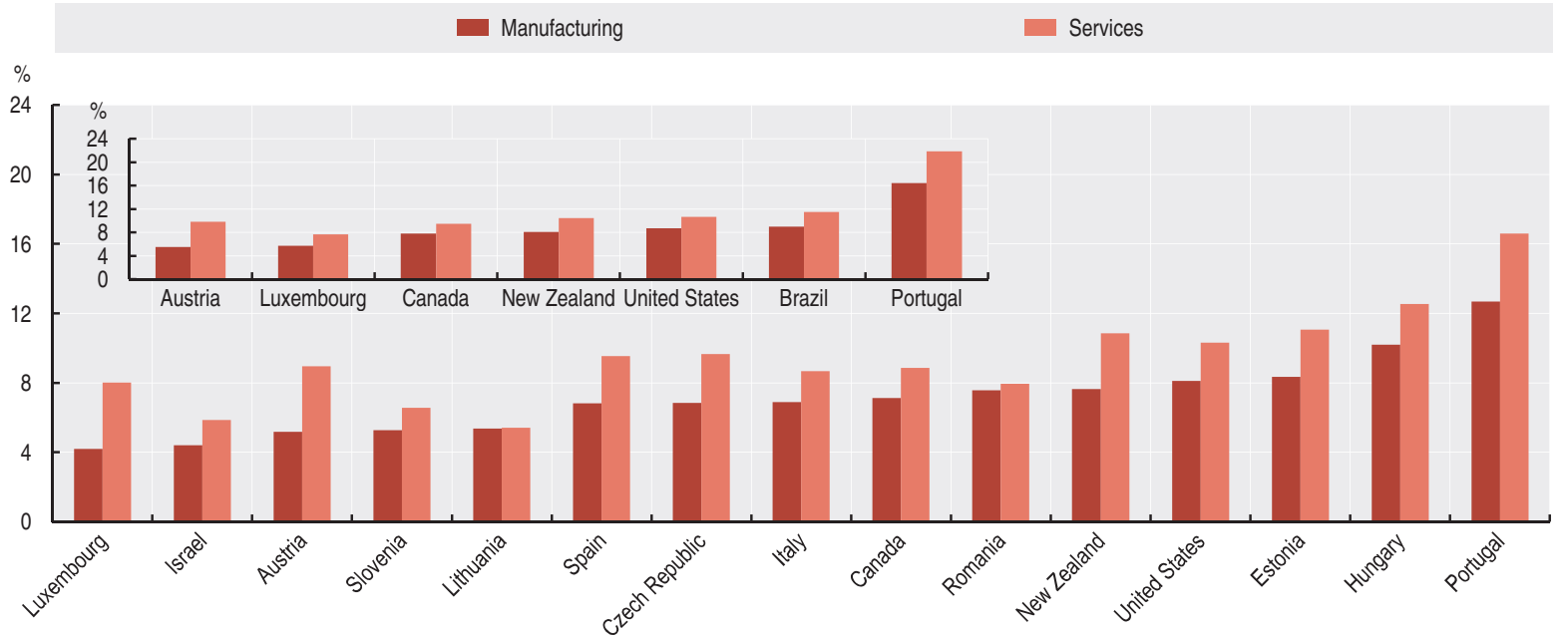

StatLink तiाs http://dx.doi.org/10.1787/888932597258 


\section{ENTERPRISE BIRTH, DEATH AND SURVIVAL}

\section{Death rate of employer enterprises}

Figure 4.10 Employer enterprise death rate in manufacturing by size class, 2007 (2008 in insert) Percentage

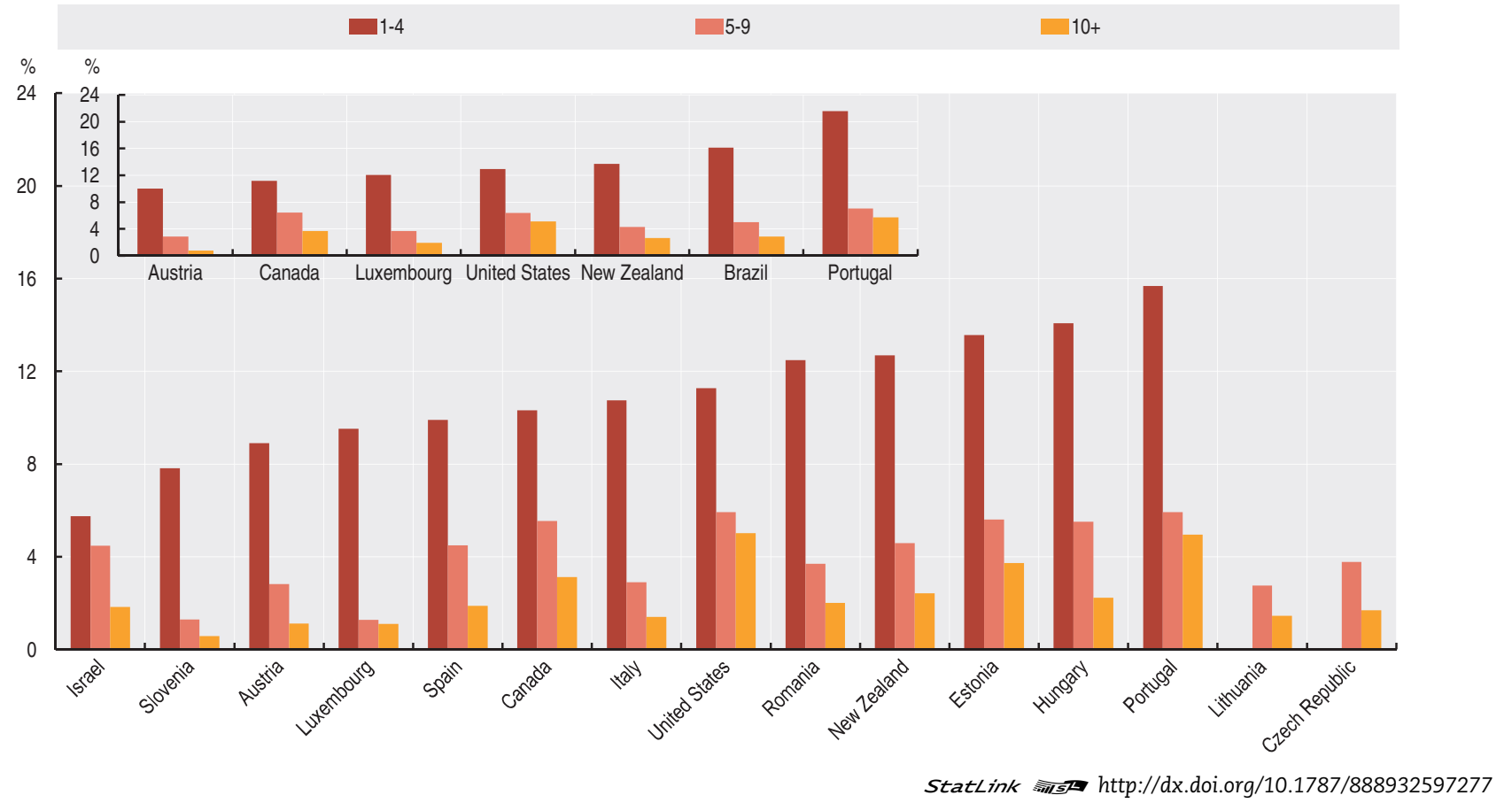

Figure 4.11 Employer enterprise death rate in services by size class, 2007 (2008 in insert) Percentage

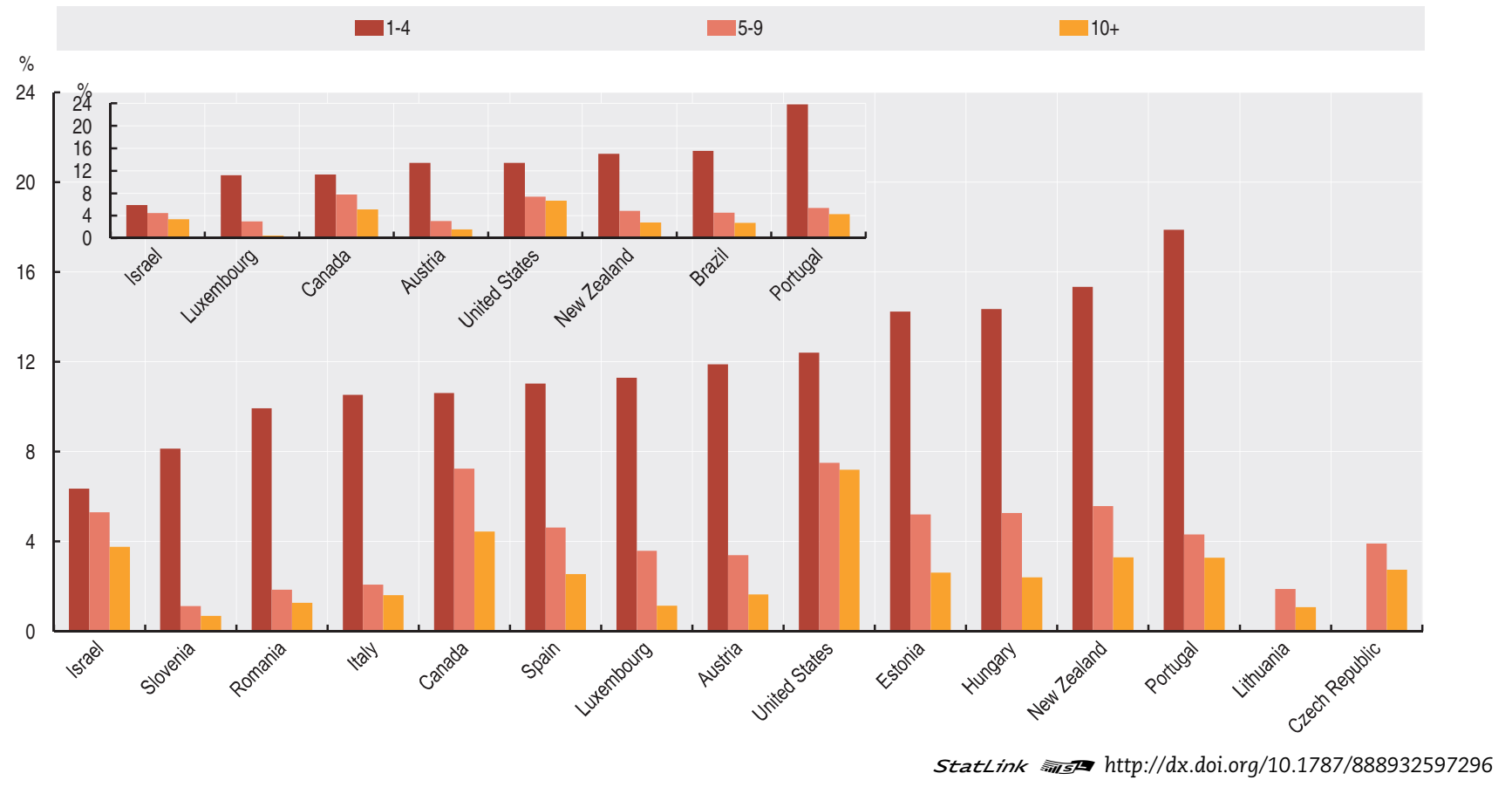




\section{ENTERPRISE BIRTH, DEATH AND SURVIVAL}

Death rate of employer enterprises

Figure 4.12 Employer enterprise death rate in various industries, 2007 (2008 in insert) Percentage
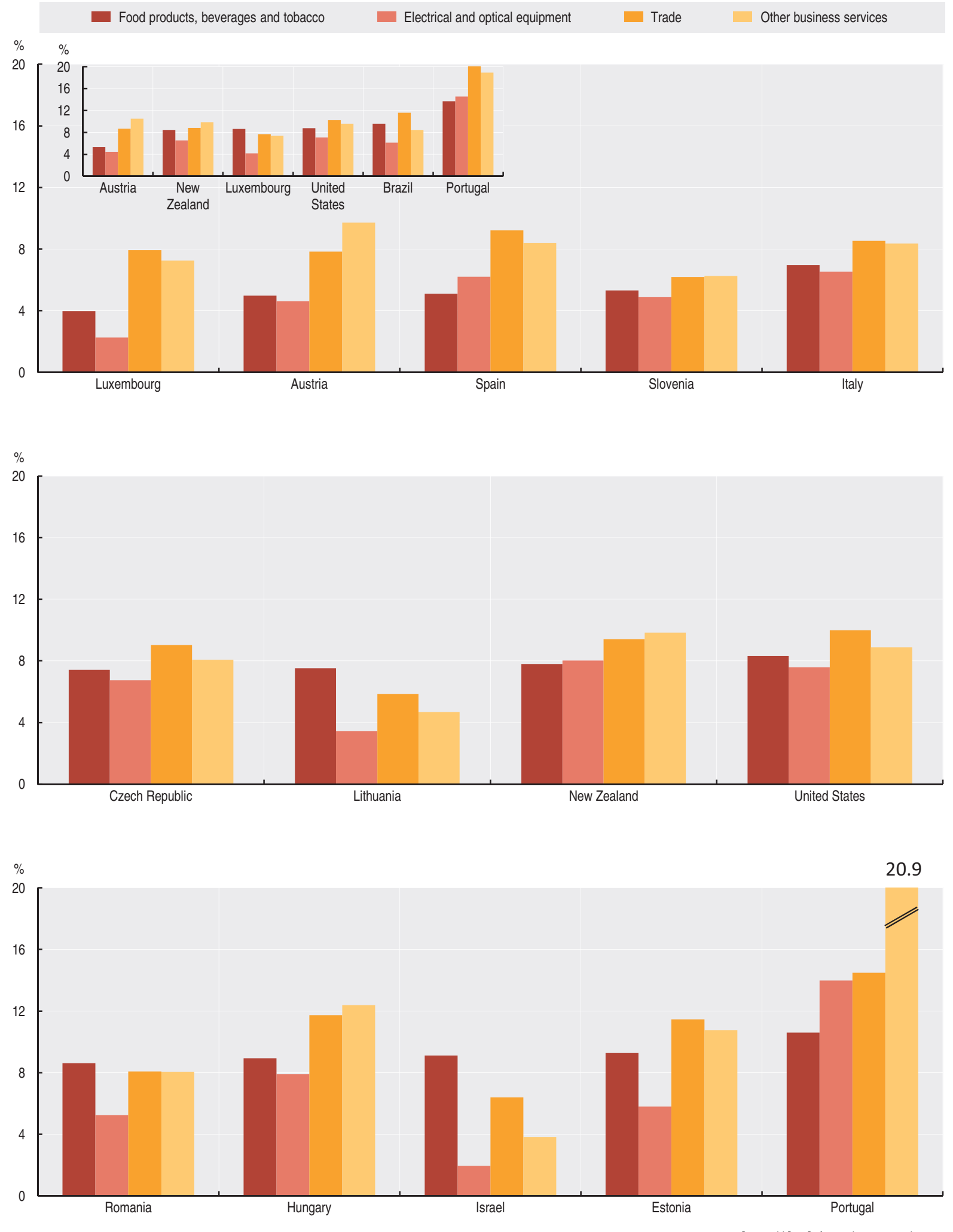

StatLink तiाst $h t t p: / / d x . d o i . o r g / 10.1787 / 888932597315$ 


\section{Churn rate of employer enterprises}

The churn rate, i.e. the sum of births and deaths of enterprises, indicates how frequently new firms are created and how often existing enterprises close down. In fact, the number of births and deaths of enterprises accounts for a sizeable proportion of the total number of firms in most economies. The indicator reflects a country's degree of "creative destruction", and it is of high interest for analysing, for example, the contribution of firm churning to aggregate productivity growth.

\section{Definitions}

The employer enterprise churn rate is compiled as the sum of the employer enterprise birth rate and the employer enterprise death rate.

The employer enterprise churn rate does not include entries and exits into the population due to mergers, break-ups or restructuring of a set of enterprises. It does not include: exits due to take-overs; entries due to split-off; and entries and exits into a sub-population resulting only from a change of activity.

There is a time lag in the employer enterprise churn rate compilation, linked to the process of confirmation of employer enterprise deaths, as it has to be checked that the enterprises considered as deaths have not been reactivated (or had no employees) in the following two years.

\section{Comparability}

Employer enterprise birth and death data used in the compilation of the employer enterprise churn rate follow the definition from the Eurostat-OECD Manual on Business Demography Statistics.

As developed in the previous sections, "employer" indicators are found to be more relevant for international comparisons than indicators covering all enterprises, as the latter are sensitive to the coverage of business registers.
Data refer to the whole population of employer enterprises, with the exception of Canada, for which data refer to employer enterprises with less than 250 employees.

Data are classified according to ISIC Revision 4 for all countries except Canada, Israel and the United States for which data are in ISIC Revision 3.

\section{Highlights}

Churn rates of employer enterprises are higher in the services sector than in manufacturing, reflecting a more significant business dynamic in services. Churn rates are relatively similar across countries and over time, ranging from $12 \%$ to $16 \%$ in manufacturing and from $18 \%$ to $22 \%$ in services. Only a few countries show much lower (i.e. Latvia) or much higher (for example, Hungary and Portugal) churn rates.

\section{Source/online database}

OECD Structural and Demographic Business Statistics (SDBS) Database, http://dx.doi.org/10.1787/sdbs-data-en.

\section{For further reading}

Ahmad, N. (2006), "A Proposed Framework For business Demography Statistics", OECD Statistics Working Papers, 2006/3, OECD Publishing, Paris, http://dx.doi.org/10.1787/145777872685.

OECD (2010), Structural and Demographic Business Statistics, OECD Publishing, http://dx.doi.org/10.1787/9789264072886-en.

Eurostat/OECD (2007), Eurostat-OECD Manual on Business Demography Statistics, OECD Publishing.

Scarpetta, S. et al. (2002), "The role of policy and institutions for productivity and firm dynamics: evidence from micro and industry data", OECD Economic Department Working Papers, No. 329, http://dx.doi.org/10.1787/547061627926.

Information on data for Israel:

http://dx.doi.org/10.1787/888932315602. 


\section{ENTERPRISE BIRTH, DEATH AND SURVIVAL}

Churn rate of employer enterprises

Figure 4.13 Employer enterprise churn rate, manufacturing

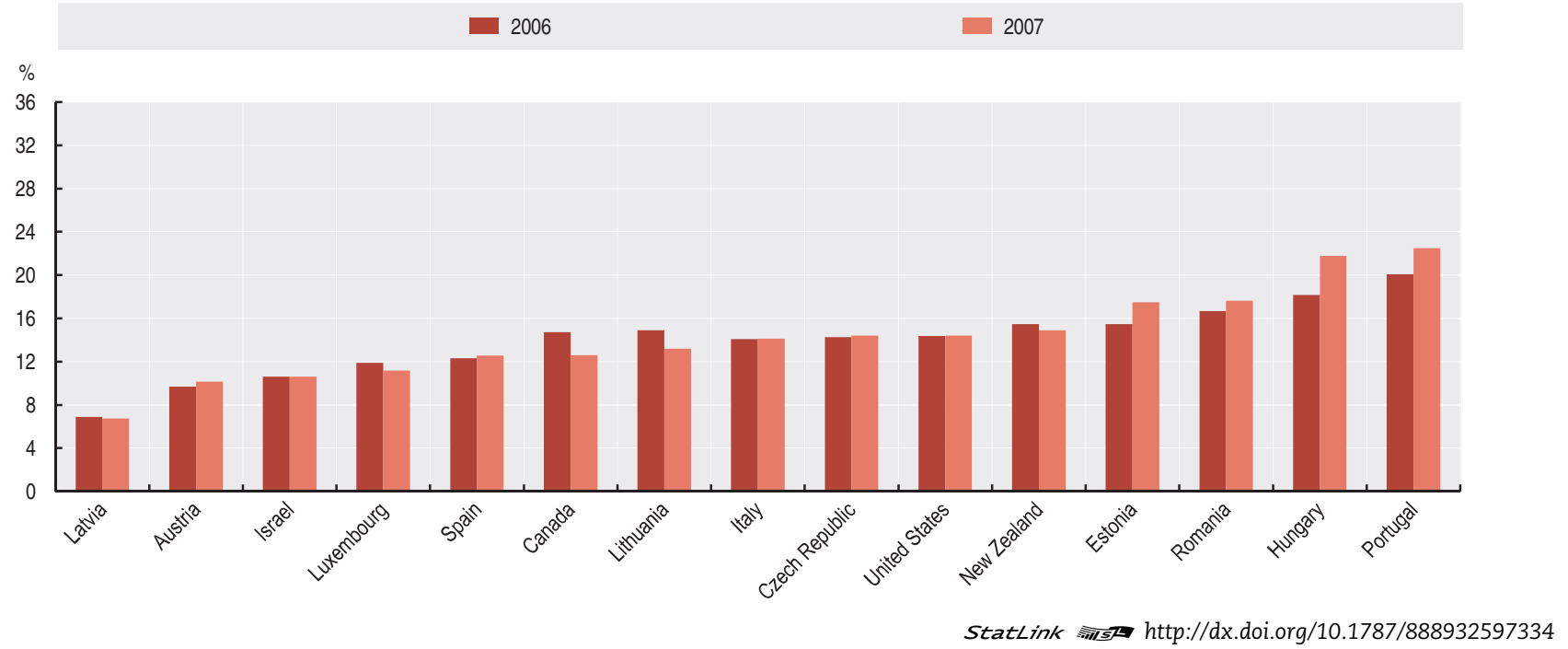

Figure 4.14 Employer enterprise churn rate, services

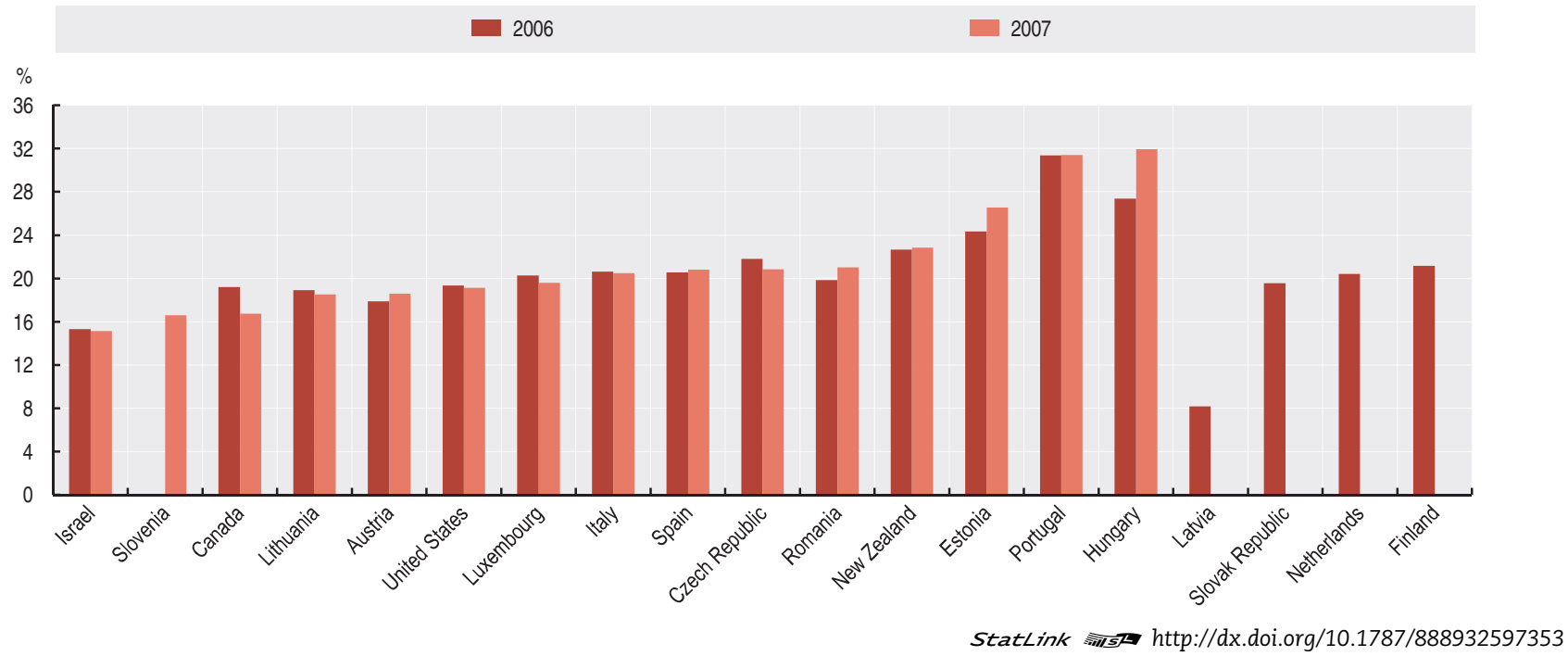


Observing the post-entry performance of firms is as important as analysing their birth rate. The survival rate of enterprises provides information on the share of enterprises surviving one or more years after birth, and allows to investigate questions such as how long do start-ups survive after creation and the differences in survival rates of enterprises across countries and industries.

\section{Definitions}

The number of $n$-year survival enterprises for a particular year $t$ refers to the number of enterprises which had at least one employee for the first time in year $t-n$ and have not died in year $t$.

An enterprise is also considered to have survived if the linked legal unit(s) has (have) ceased to be active, but their activity has been taken over by a new legal unit set up specifically to take over the factors of production of that enterprise (survival by takeover). This definition of survival excludes cases in which enterprises merge or are taken over by an existing enter prise in year $\mathrm{t}-\mathrm{n}$.

The survival of an enterprise is an event that should always be observed between two consecutive years. For instance, an enterprise born in year $\mathrm{t}-2$ should be considered as having survived to t only if it had at least one employee also in year $\mathrm{t}-1$, and so forth.

The employer enterprise survival rate measures the number of enterprises of a specific birth cohort that have survived over different years. The n-year survival rate for a reference year $t$ is calculated as the number of $\mathrm{n}$-year survival enterprises as a percentage of all enterprises that reported at least one employee for the first time in year $\mathrm{t}-\mathrm{n}$.

The share of n-year-old employer enterprises for a particular year $t$ refers to the number of n-year survival enterprises as a percentage of the total employer enterprise population in year $t$.

\section{Comparability}

Employer enterprise survival data in this publication follow the definition from the Eurostat-OECD Manual on Business Demography Statistics.
Data refer to the whole population of employer enterprises, with the exception of Canada, for which data refer to employer enterprises with less than 250 employees.

Data are classified according to ISIC Revision 4 for all countries except Canada, Israel and the United States for which data are in ISIC Revision 3.

\section{Highlights}

The survival rates of employer enterprises in the manufacturing sector are slightly higher than in the services sector and the difference persists in every year after birth; Canada and the Slovak Republic are exceptions, with the survival rates almost identical in the two sectors. On average, the survival rates after one year are around 85 to $90 \%$ in manufacturing and a little lower in services, and they continue to drop constantly in the following years. Young enterprises represent however a larger share of the total population of enterprises in the services sector than in the manufacturing sector, due to the higher birth rate of employer enterprises in services.

\section{Source/Online database}

OECD Structural and Demographic Business Statistics (SDBS) Database, http://dx.doi.org/10.1787/sdbs-data-en.

\section{For further reading}

Ahmad, N. (2006), “A Proposed Framework for Business Demography Statistics", OECD Statistics Working Papers, 2006/3, OECD Publishing, Paris, http://dx.doi.org/10.1787/145777872685.

Eurostat/OECD (2007), Eurostat-OECD Manual on Business Demography Statistics, OECD Publishing.

OECD (2010), Structural and Demographic Business Statistics, OECD Publishing, http://dx.doi.org/10.1787/9789264072886-en.

Information on data for Israel:

http://dx.doi.org/10.1787/888932315602. 


\section{ENTERPRISE BIRTH, DEATH AND SURVIVAL}

Survival rate of employer enterprises

Figure 4.15 Enterprise survival rates, 2005 cohort

Percentage

Manufacturing (\%)

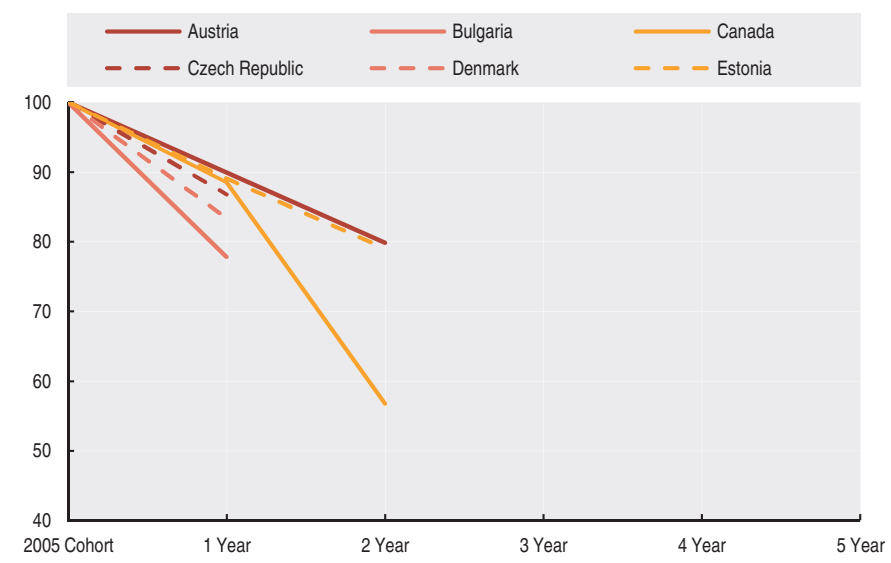

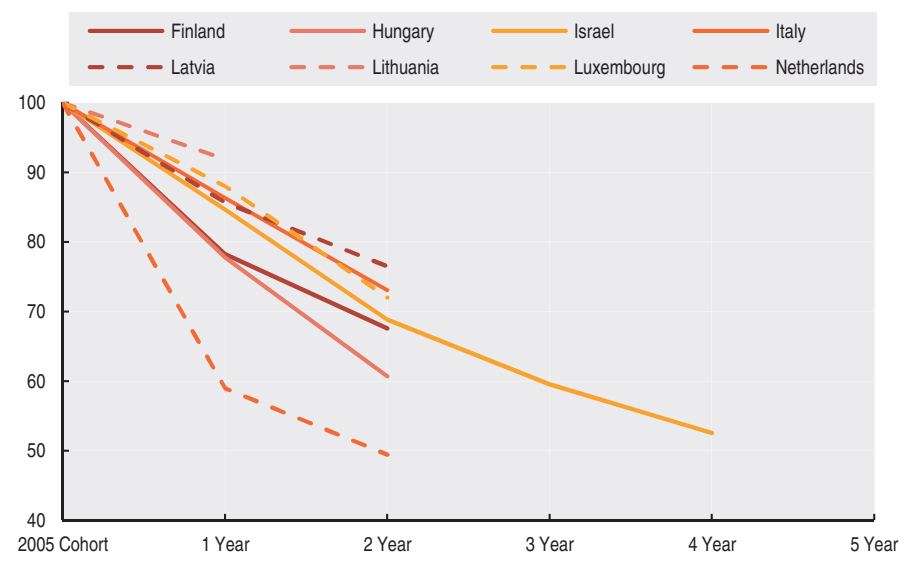
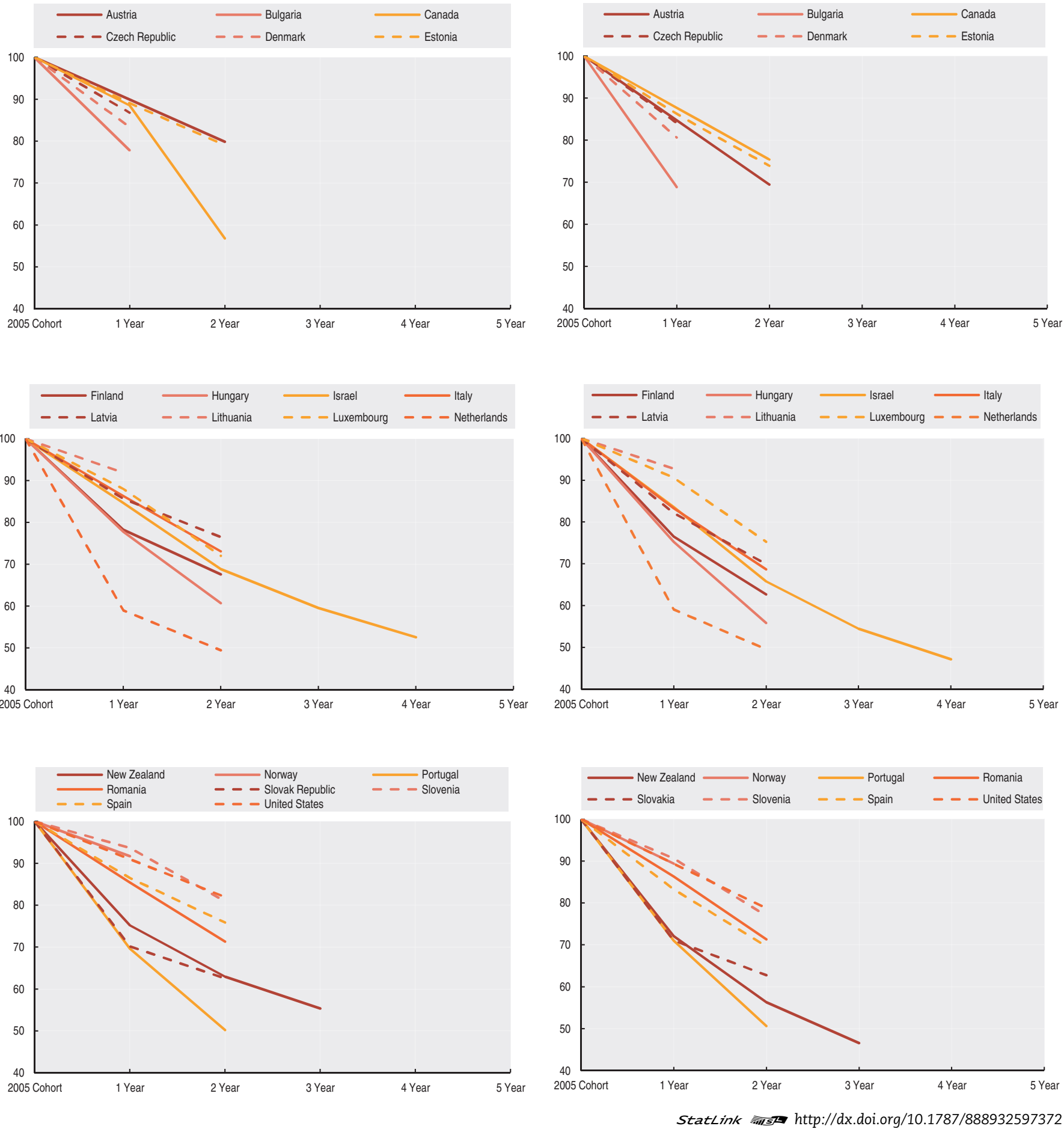


\section{ENTERPRISE BIRTH, DEATH AND SURVIVAL}

\section{Survival rate of employer enterprises}

Figure 4.16 Share of young enterprises, manufacturing, 2008

Percentage
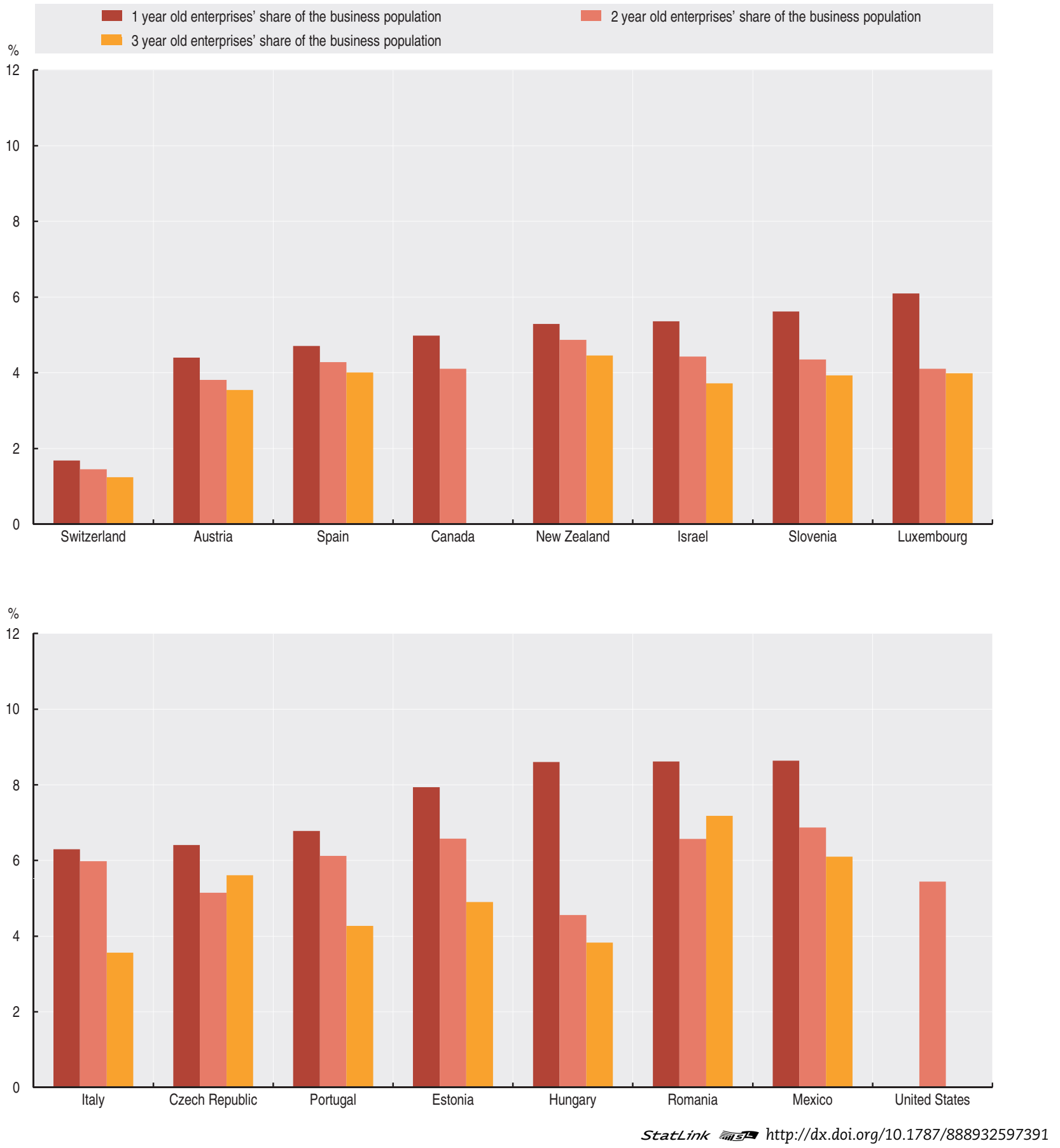


\section{ENTERPRISE BIRTH, DEATH AND SURVIVAL}

Survival rate of employer enterprises

Figure 4.17 Share of young enterprises, services, 2008

Percentage
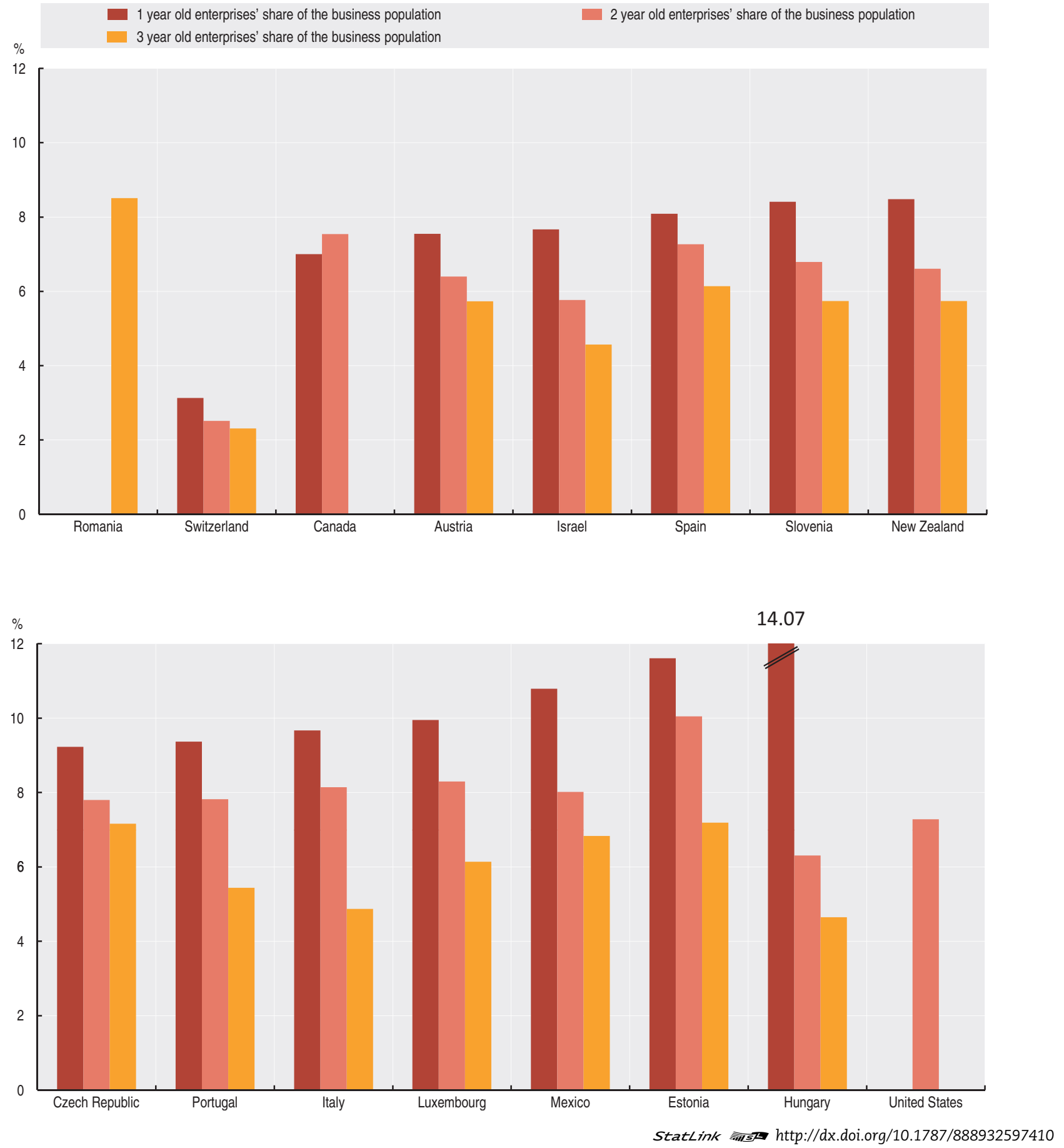

5. EMPLOYMENT CREATION AND DESTRUCTION

Employment creation and destruction by employer enterprise births and deaths

Employment creation and destruction in surviving enterprises

ENTREPRENEURSHIP AT A GLANCE 2012 ๑ OECD 2012

79 


\section{EMPLOYMENT CREATION AND DESTRUCTION}

\section{Employment creation and destruction by employer enterprise births and deaths}

The observation of the employment created by firm births or destructed by firm deaths provides an indication of how enterprise business demography contributes to overall employment changes in the economy.

\section{Definitions}

The employment creation by births is measured as the employment share of employer enterprise births. It is calculated as the number of persons employed in the reference period $t$ in employer enterprises newly born in $t$ divided by the number of persons employed in $t$ in the population of employer enterprises.

Symmetrically, the employment destruction by deaths is measured as the employment share of employer enterprise deaths. It is calculated as the number of persons employed in the reference period t in exiting employer enterprises divided by the number of persons employed in $t$ in the population of employer enterprises.

While there exists much evidence in support of, alternatively, the dominance of small or larger firms in net employment growth, research in the United States brought to the fore the fact that the age of enterprises could be more relevant than their size in determining their contribution to employment growth. In particular, young enterprises seem to be responsible for a large proportion of employment churning, i.e. creation and destruction of jobs in the economy, because they are more volatile: start-ups have higher probabilities of exiting the market in their first years of life.

\section{Comparability}

Data refer to the whole population of employer enterprises. Data are classified according to ISIC Revision 4 for all countries except Israel for which data are in ISIC Revision 3.

\section{Highlights}

There are important differences across countries in the extent to which the birth and death of employer enterprises affect, respectively, the creation and destruction of jobs in the economy. In all countries, however, the level of employment churning is quite stable over the years, and constantly higher in services than in the manufacturing sector; only in the Slovak Republic significant variations of the level of employment churning are observed.

\section{Source/Online database}

OECD Structural and Demographic Business Statistics (SDBS) Database, http://dx.doi.org/10.1787/sdbs-data-en.

\section{For further reading}

Ahmad, N. (2006), “A Proposed Framework For business Demography Statistics", OECD Statistics Working Papers, 2006/3, OECD Publishing, Paris, http://dx.doi.org/10.1787/145777872685.

Eurostat/OECD (2007), Eurostat-OECD Manual on Business Demography Statistics, OECD Publishing.

Haltiwanger, J., R.S. Jarmin and J. Miranda (2010), "Who create jobs? Small us. Large us. Young”, Discussion Papers, US Census Bureau.

Information on data for Israel:

http://dx.doi.org/10.1787/888932315602. 


\section{EMPLOYMENT CREATION AND DESTRUCTION}

\section{Fimployment creation and destruction by employer enterprise births and deaths}

Figure 5.1 Employment creation by employer enterprise births by sector, 2008

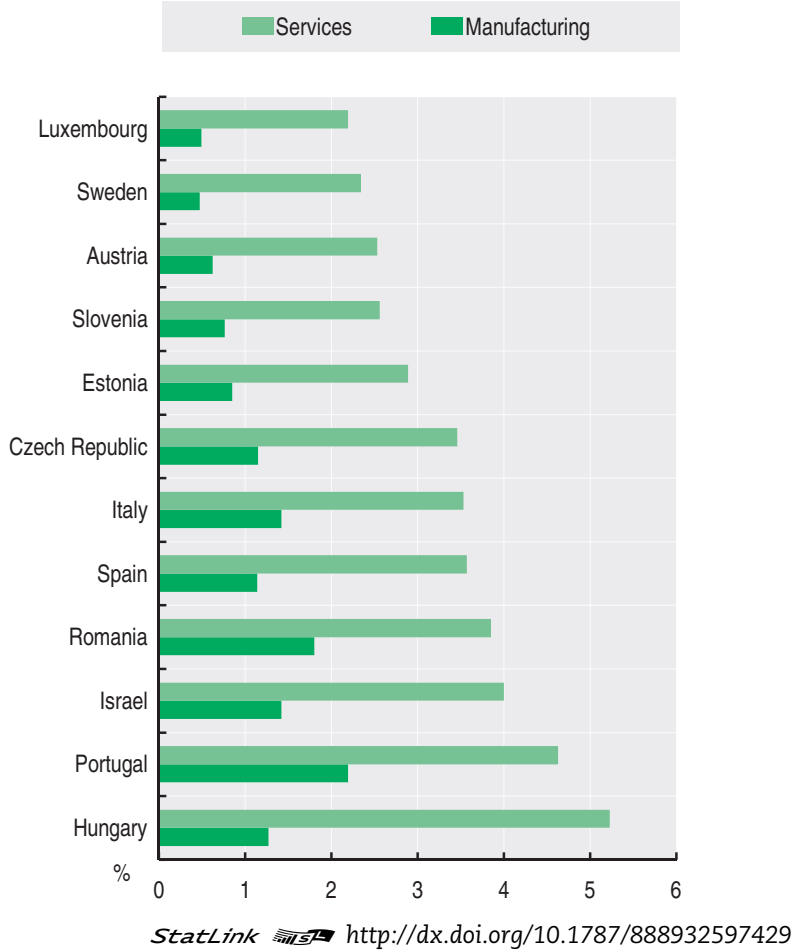

5.3 Employment creation by employer enterprise births, total economy

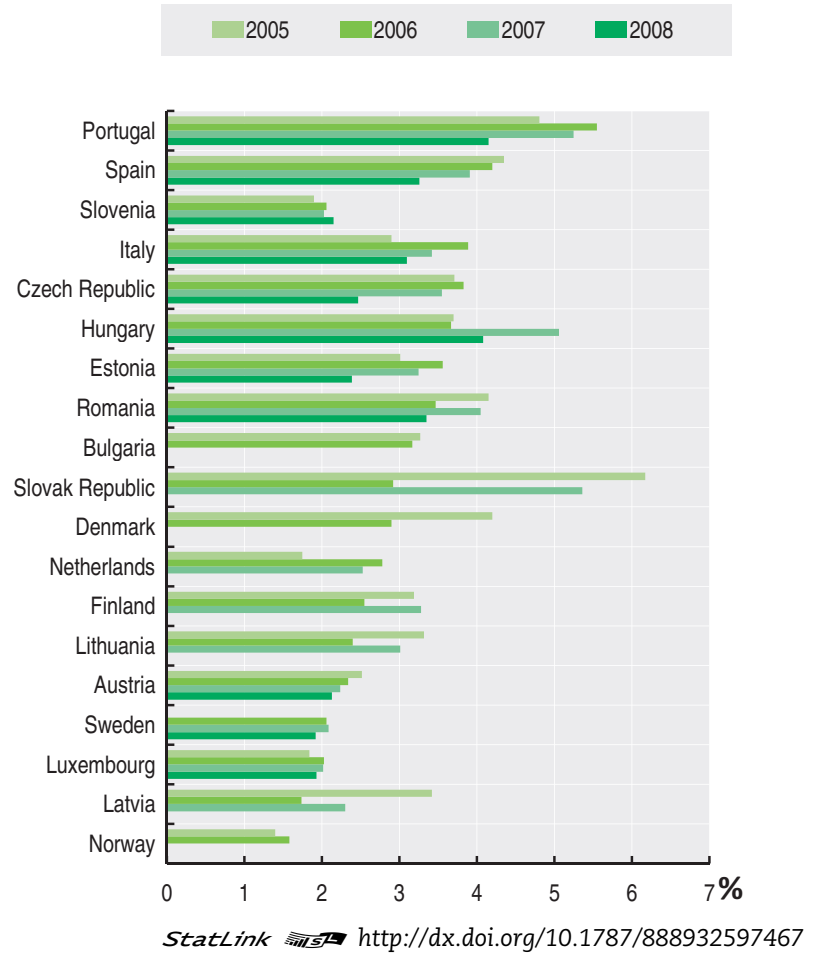

Figure 5.2 Employment destruction by employer enterprise deaths by sector, 2008

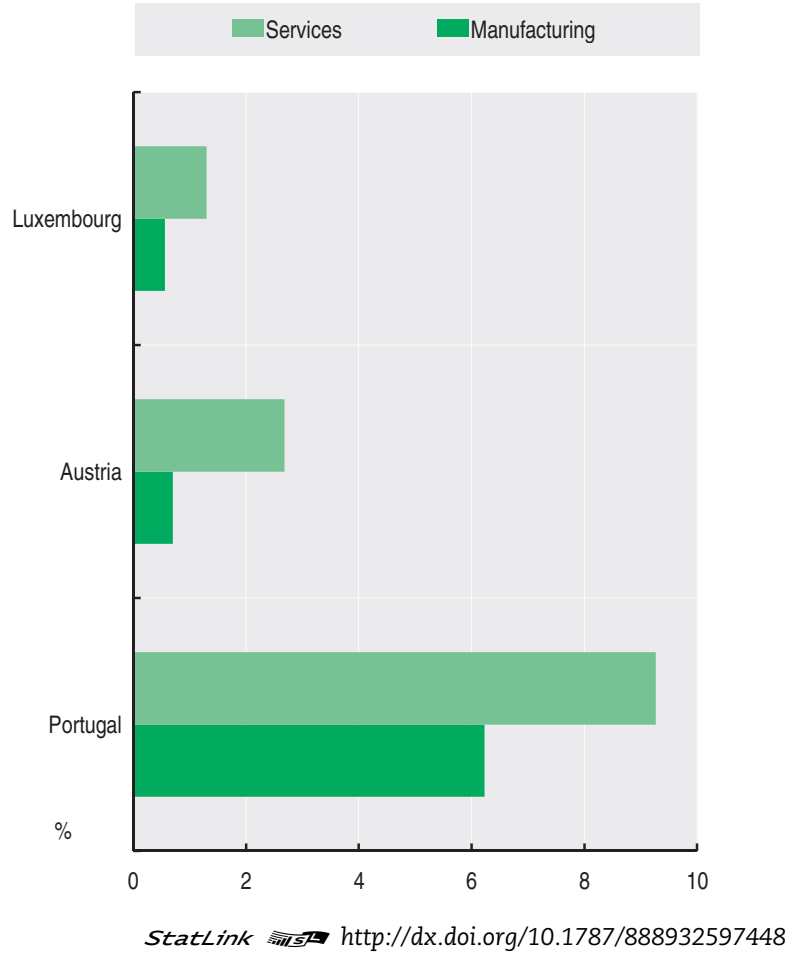

Figure 5.4 Employment destruction by employer enterprise deaths, total economy

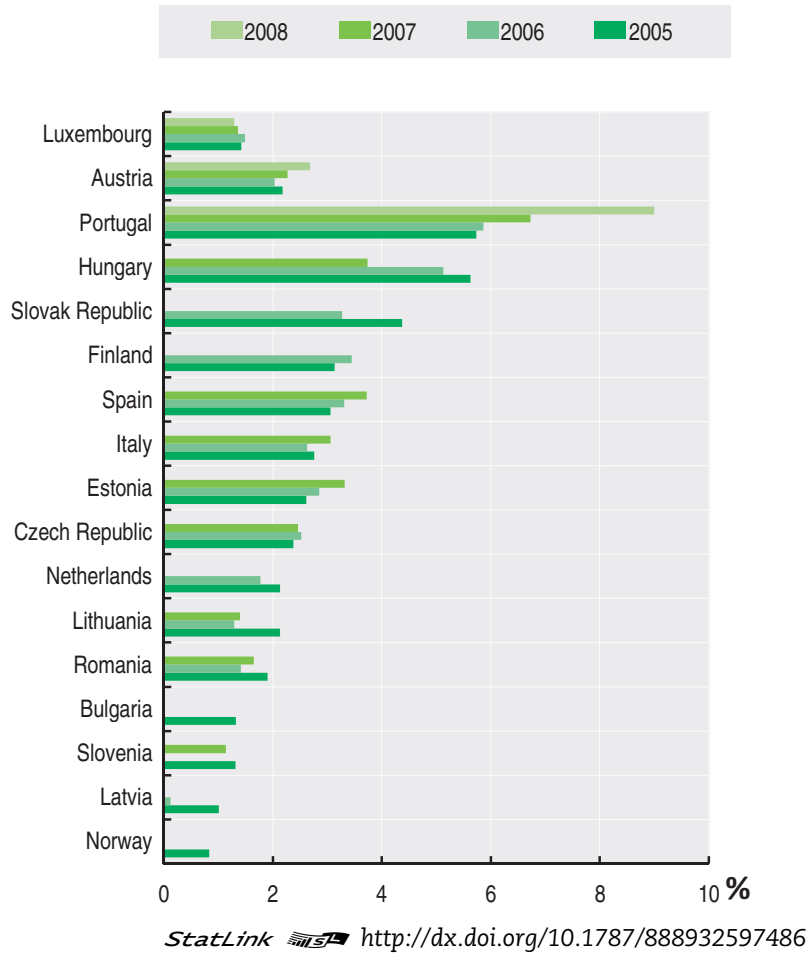




\section{EMPLOYMENT CREATION AND DESTRUCTION}

\section{Bmployment creation and destruction in surviving enterprises}

The comparison of the employment share of one-year (two-year) old enterprises in their year of birth with their employment share after one year (two years) of existence, provides an indication of how rapidly the young surviving enterprises are increasing their number of persons employed beyond the initial level and contribute to overall employment changes in the economy.

\section{Definitions}

The employment share at birth of one-year (two-year) old employer enterprises refers to the number of persons employed in the year of birth by employer enterprises that will have survived one year (two years), divided by the total number of persons employed.

The employment share of one-year (two-year) old employer enterprises refers to the number of persons employed in one-year (two-year) old employer enterprises, divided by the total number of persons employed.

\section{Comparability}

Data refer to the whole population of employer enterprises. Data are classified according to ISIC Revision 4 for all countries except Israel for which data are in ISIC Revision 3.

\section{Highlights}

On average, the employment shares of one-year old enterprises in 2008 have shown an increase higher than $20 \%$ compared to their year of birth. The increase in the employment share of two-year old enterprises compared to their year of birth (about 43\%) indicates the positive dynamic of employment in young, surviving enterprises.

\section{Source/Online database}

OECD Structural and Demographic Business Statistics (SDBS) Database, http://dx.doi.org/10.1787/sdbs-data-en.

\section{For further reading}

Ahmad, N. (2006), “A Proposed Framework For business Demography Statistics", OECD Statistics Working Papers, 2006/3, OECD Publishing, Paris, http://dx.doi.org/10.1787/145777872685.

Eurostat/OECD (2007), Eurostat-OECD Manual on Business Demography Statistics, OECD Publishing.

Haltiwanger, J., R.S. Jarmin and J. Miranda (2010), "Who create jobs? Small us. Large us. Young”, Discussion Papers, US Census Bureau. 


\section{EMPLOYMENT CREATION AND DESTRUCTION}

\section{Fmployment creation and destruction in surviving enterprises}

Figure 5.5 Employment in year of birth and in the 1st survival year, total economy, 2008

As a percentage of employment in the population of enterprises

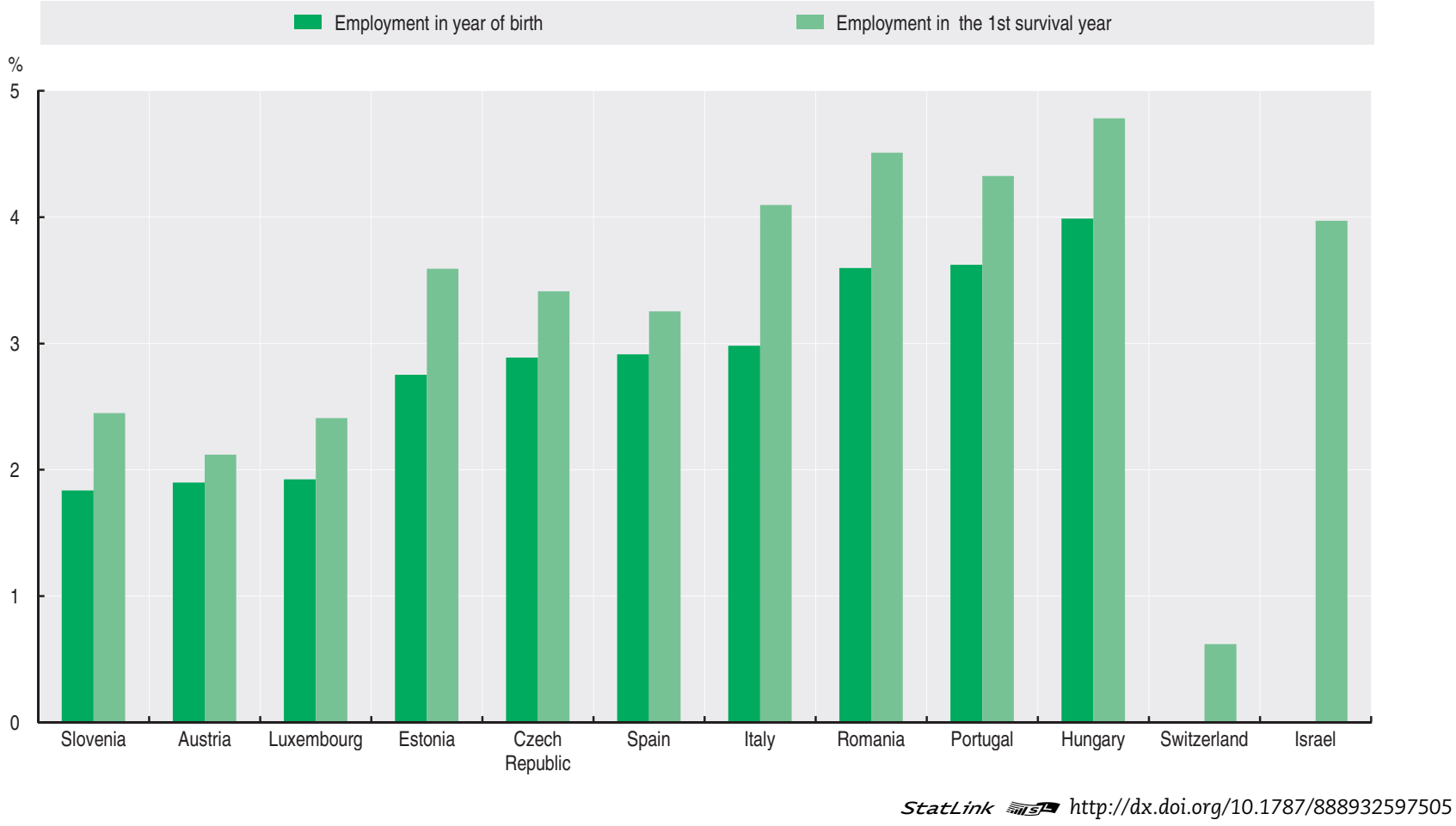

Figure 5.6 Employment in year of birth and in the 2nd survival year, total economy, 2008 As a percentage of employment in the population of enterprises

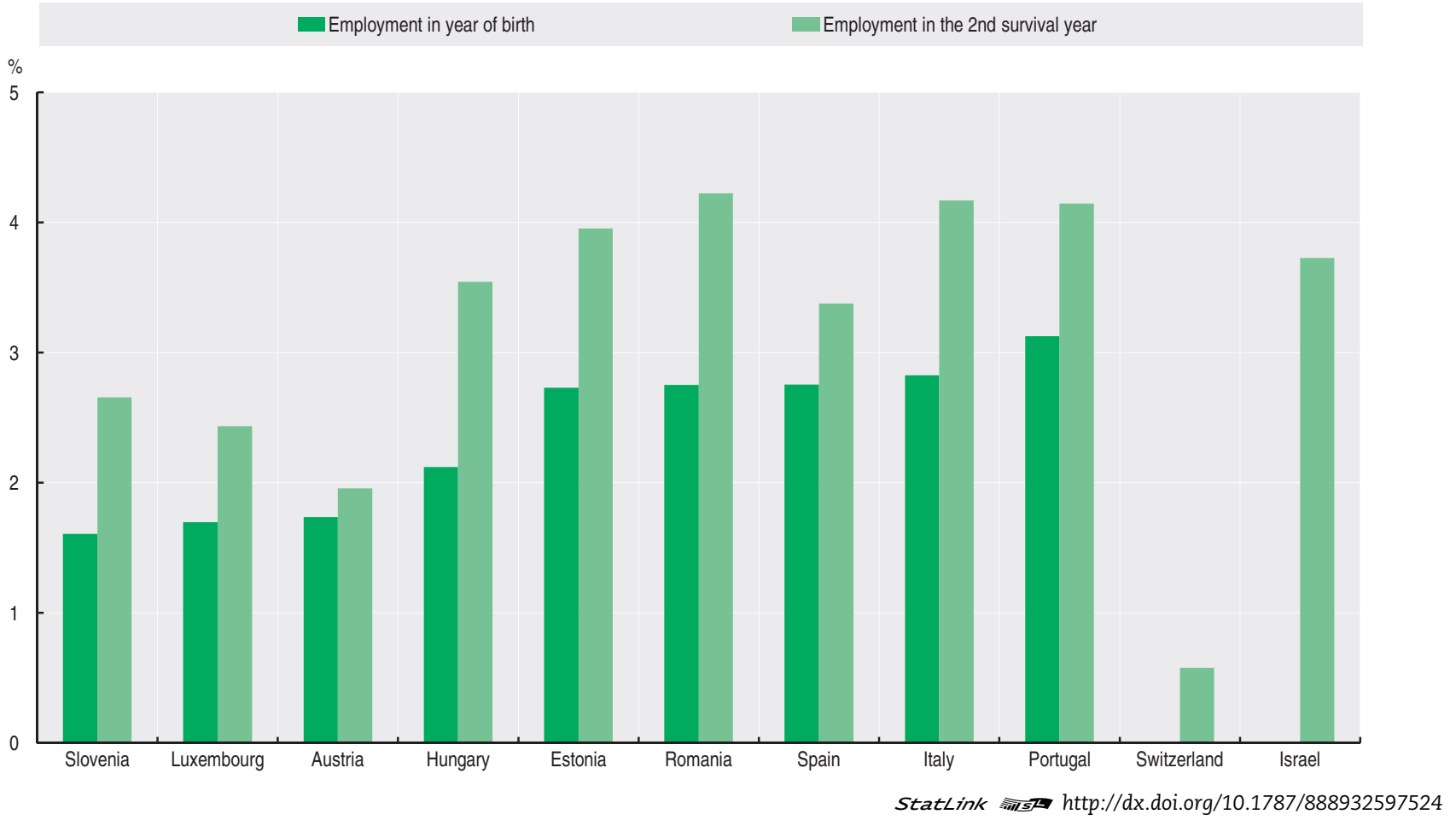



6. ENTERPRISE GROWTH

High-growth enterprise rate

Gazelle rate

ENTREPRENEURSHIP AT A GLANCE 2012 ๑ OECD 2012

85 
High-growth enterprises are firms that by their extraordinary growth make the largest contribution to net job creation, despite typically representing a small proportion of the business population. With their presence in the economy considered promising for the creation of more jobs and innovation, interest in high-growth firms is high among policy makers.

\section{Definitions}

High-growth enterprises, as measured by employment (or by turnover), are enterprises with average annualised growth in employees (or in turnover) greater than $20 \%$ a year, over a three-year period, and with ten or more employees at the beginning of the observation period.

Medium-growth enterprises, as measured by employment, are enterprises with average annualised growth in employees between $10 \%$ and $20 \%$ per year, over a three-year period, and with ten or more employees at the beginning of the observation period.

The share of high-growth enterprises and share of medium-growth enterprises measure, respectively, the number of high-growth enterprises and the number of medium-growth enterprises as a percentage of the population of enterprises with ten or more employees.

\section{Comparability}

A size threshold of ten employees at the start of any observation period was set to avoid the small size class bias that the above definition of high growth inevitably contains. The optimal threshold in terms of firm size at start, growth rate and growth period needs to balance two competing criteria: the first is to provide as detailed and as meaningful information as possible, and the second is to maximise information that can be disclosed, i.e. that satisfies confidentiality rules and allows producing the indicators at as detailed an industry level as possible, and by standard (employment) size classes.

Setting the employment thresholds too low, for example, will reduce disclosure problems but at the same time result in disproportionate numbers of small enterprises appearing in the statistics. If the threshold is too high, however, disclosure problems increase, particularly for smaller economies, with significantly less large companies than larger economies. It is clear that an absolute threshold will affect countries and industries differently, depending on their size.

The size threshold of ten or more employees holds for both the turnover and employment measures. The advantage is that the initial population is the same, regardless of whether growth is measured in employment or turnover. Moreover, it would be difficult to apply a consistent turnover threshold across all countries because of exchange rates, inflation, etc.

Data for Canada refer to employer enterprises with less than 250 employees.

Manufacturing data for Canada exclude Mining and Utilities.

Data are classified according to ISIC Revision 4 for all countries except Canada, Israel and the United States for which data are in ISIC Revision 3.

\section{Highlights}

High-growth enterprises represent on average a small share of the total population, typically between 3.5\% and $6 \%$ when measured by employment growth; the proportion of enterprises that show high growth in turnover is higher, with percentages going up to 20 and even more. Also, in most countries high growth firms (by employment) are in general more frequent in services, while their prevalence is higher in manufacturing when high-growth is measured by turnover.

\section{Source/online database}

OECD Structural and Demographic Business Statistics (SDBS) Database, http://dx.doi.org/10.1787/sdbs-data-en.

\section{For further reading}

Ahmad, N. and D. Rude Petersen (2007), High-Growth Enterprises and Gazelles - Preliminary and Summary Sensitivity Analysis, OECD-FORA, Paris, www.oecd.org/document/31/ 0,3746,en_2825_499554_39151327_1_1_1_1,00.html.

Ahmad, N. and E. Gonnard (2007), "High-growth Enterprises and Gazelles", paper prepared for the International Consortium on Entrepreneurship (ICE), Copenhagen, Denmark, http://ice.foranet.dk/upload/highgrowth.pdf.

Eurostat/OECD (2007), Eurostat-OECD Manual on Business Demography Statistics, OECD Publishing, http://dx.doi.org/10.1787/9789264072886-en.

OECD (2007), The OECD Entrepreneurship Indicators Programme: Workshop on the Measurement of High-growth Enterprises, 19 November 2007, Paris.

OECD (2010), Structural and Demographic Business Statistics, OECD Publishing.

Information on data for Israel:

http://dx.doi.org/10.1787/888932315602. 


\section{ENTERPRISE GROWTH}

High-growth enterprise rate

A corrigendum has been issued for this page. See http://www.oecd.org/about/publishing/Corrigendum_EAG.pdf Figure 6.1 Rate of high-growth enterprises, 2008 or latest available year (2009 in insert)

Measured by employment growth

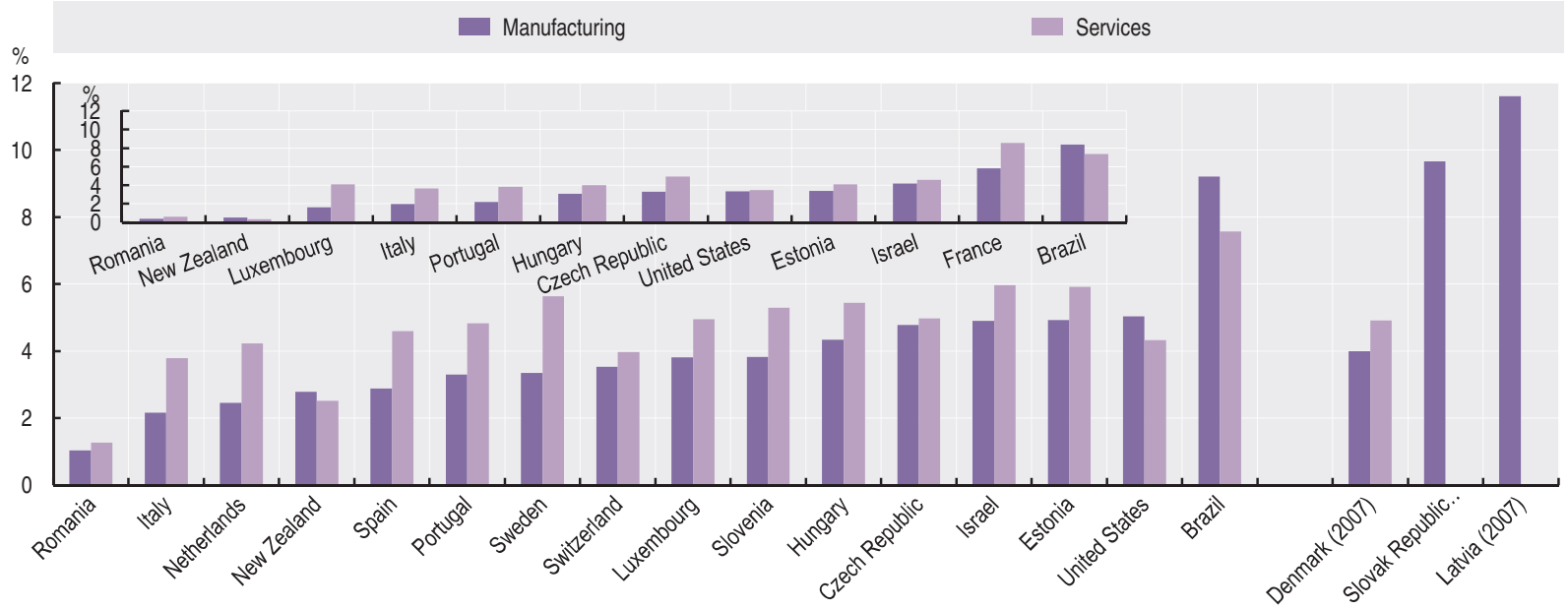

StatLink Aist http://dx.doi.org/10.1787/888932597543

Figure 6.2 Rate of medium-growth enterprises, 2008 or latest available year (2009 in insert) Measured by employment growth

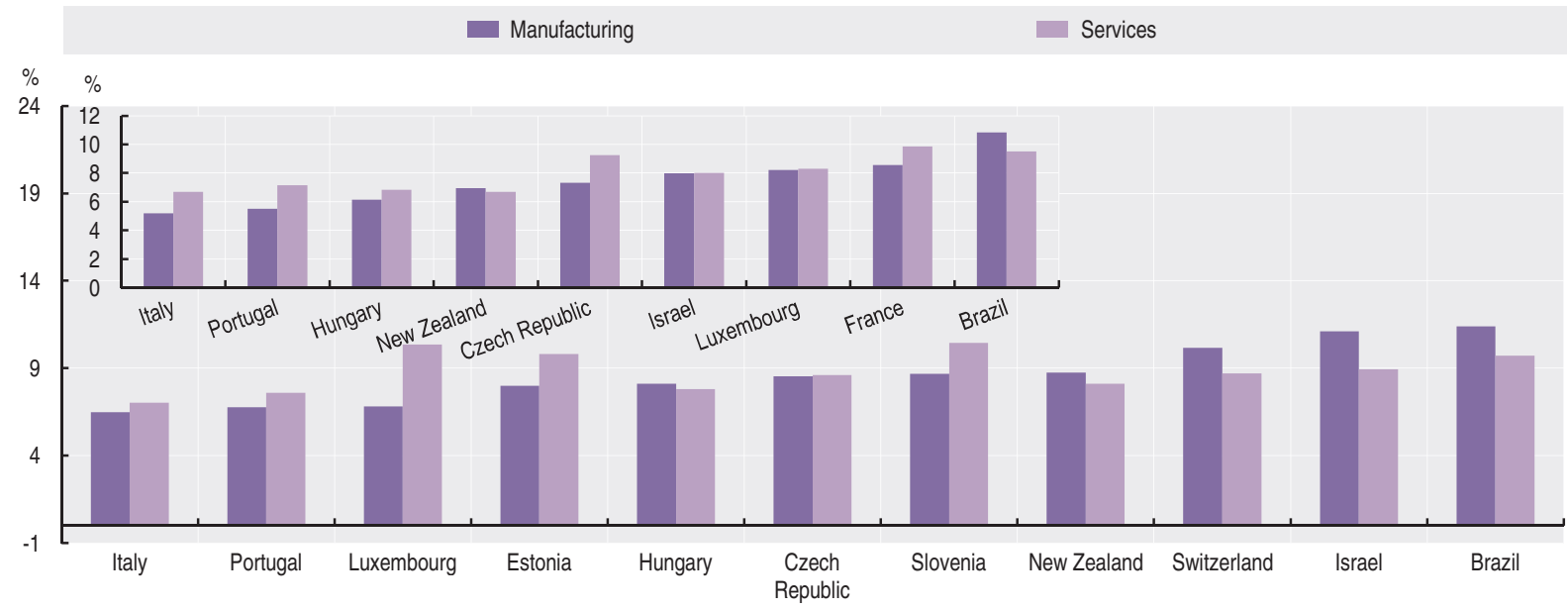

Figure 6.3 Rate of high-growth enterprises, 2008 or latest available year (2009 in insert)

StatLink जilst http://dx.doi.org/10.1787/888932597562 Measured by turnover growth

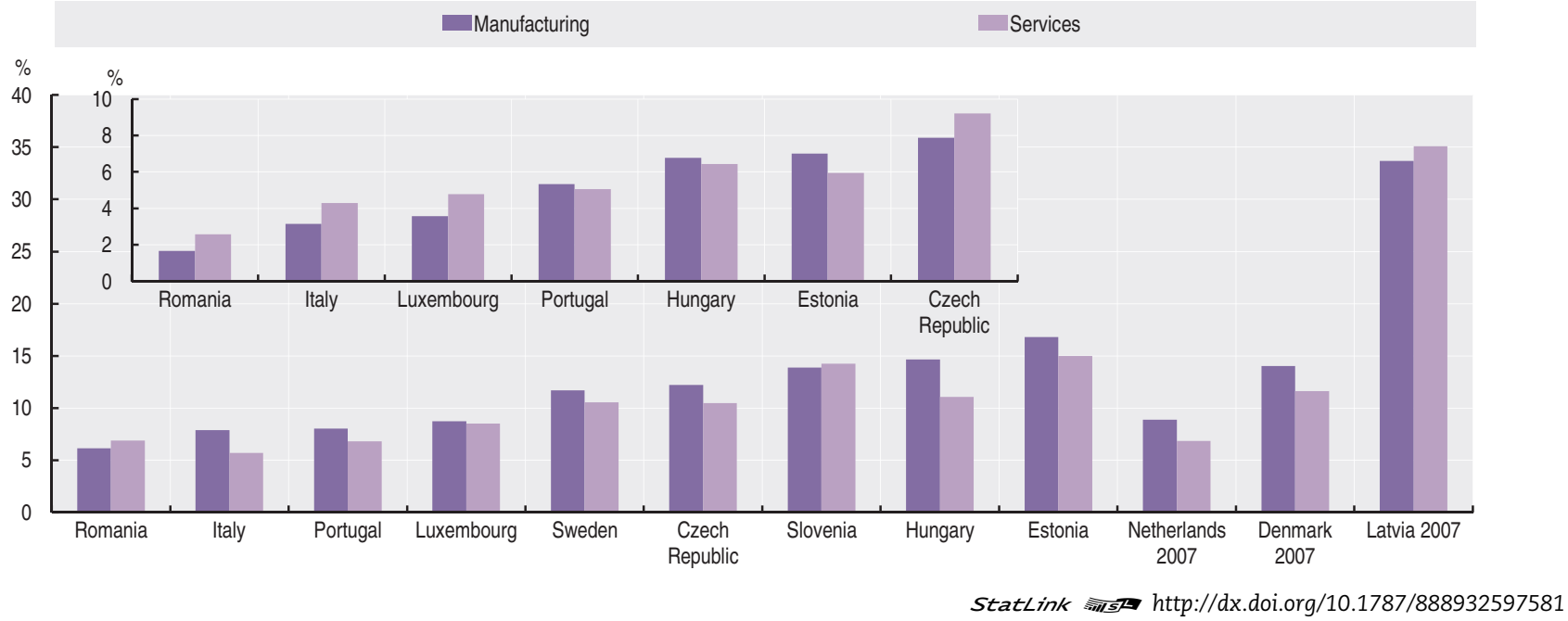




\section{ENTERPRISE GROWTH}

\section{Gazelle rate}

Gazelles represent the young enterprises among the population of high-growth enterprises. Their role in job creation is of particular interest to policy makers.

\section{Definitions}

Gazelles form a subset of the group of high-growth enterprises; they are high-growth enterprises born five years or less before the end of the three-year observation period.

Gazelles are enterprises that have been employers for a period of up to five years, with average annualised growth in employees (or in turnover) greater than $20 \%$ a year over a three-year period and with ten or more employees at the beginning of the observation period.

Young medium-growth enterprises, as measured by employment, are enterprises that have been employers for a period of up to five years, with average annualised growth in employees between $10 \%$ and $20 \%$ per year over a three-year period and with ten or more employees at the beginning of the observation period.

The share of gazelles and the share of young medium-growth enterprises measure respectively the number of gazelles and the number of young medium-growth enterprises as a percentage of the population of enterprises with ten or more employees.

\section{Comparability}

Data for Canada refer to employer enterprises with less than 250 employees.

Manufacturing data for Canada exclude Mining and Utilities.

Data are classified according to ISIC Revision 4 for all countries except Canada, Israel and the United States for which data are in ISIC Revision 3.

\section{Highlights}

In a majority of countries, less than $1 \%$ (or even less than $0.5 \%$ ) of the firms with ten or more employees are gazelles when the growth measure is based on employment; the share is slightly higher for gazelles as measured by turnover growth. Only in a few East European economies gazelles represent a share up to $4 \%$, depending on the growth criteria. To be noted, the shares have been stable over the past three years of data collection.

\section{Source/Online database}

OECD Structural and Demographic Business Statistics (SDBS) Database, http://dx.doi.org/10.1787/sdbs-data-en.

\section{For further reading}

Ahmad, N. and D. Rude Petersen (2007), High-Growth Enterprises and Gazelles -Preliminary and Summary Sensitivity Analysis, OECD-FORA, Paris.

Ahmad, N. and E. Gonnard, (2007), "High-growth Enterprises and Gazelles", paper prepared for the International Consortium on Entrepreneurship (ICE), Copenhagen, ensDenmark, http://ice.foranet.dk/upload/highgrowth.pdf.

Eurostat/OECD (2007), Eurostat-OECD Manual on Business Demography Statistics, OECD Publishing.

OECD (2007), The OECD Entrepreneurship Indicators Programme: Workshop on the Measurement of High-growth Enterprises, 19 November 2007, Paris,

www.oecd.org/document/31/

0,3746,en_2825_499554_39151327_1_1_1_1,00.html.

OECD (2010), Structural and Demographic Business Statistics, OECD Publishing. http://dx.doi.org/10.1787/9789264072886-en.

Information on data for Israel:

http://dx.doi.org/10.1787/888932315602. 


\section{ENTERPRISE GROWTH}

Gazelle rate

A corrigendum has been issued for this page. See http://www.oecd.org/about/publishing/Corrigendum_EAG.pdf Figure 6.4 Share of gazelles, 2008 or latest available year (2009 in insert)

Measured by employment growth

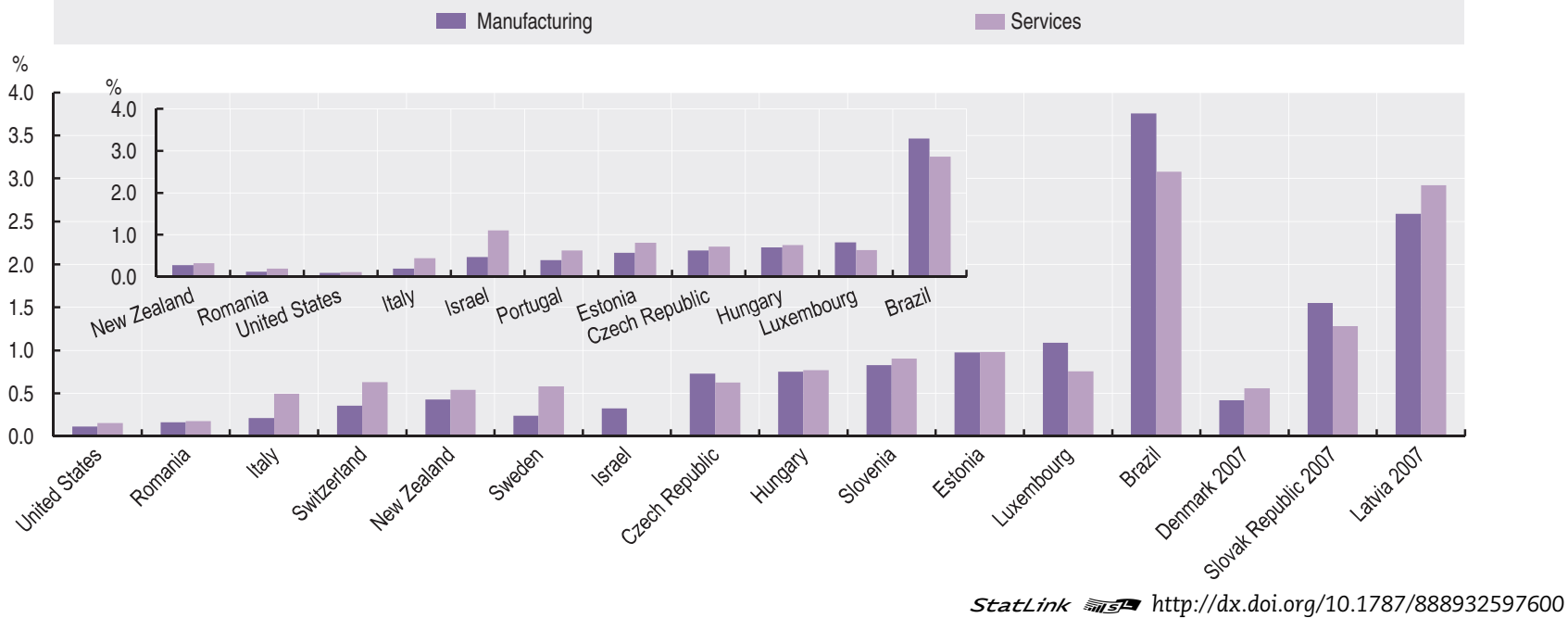

Figure 6.5 Share of young medium-growth enterprises, 2008 or latest available year (2009 in insert) Measured by employment growth

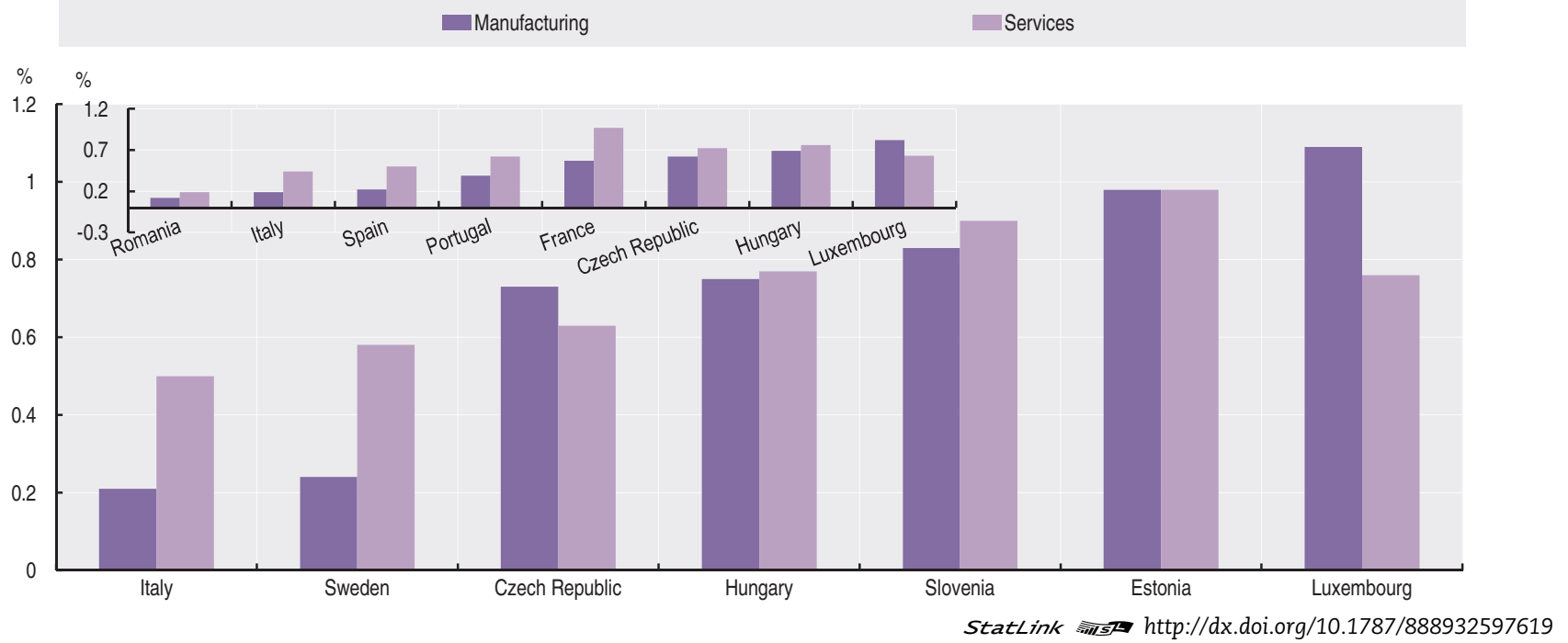

Figure 6.6 Share of gazelles, 2008 or latest available year (2009 in insert) Measured by turnover growth

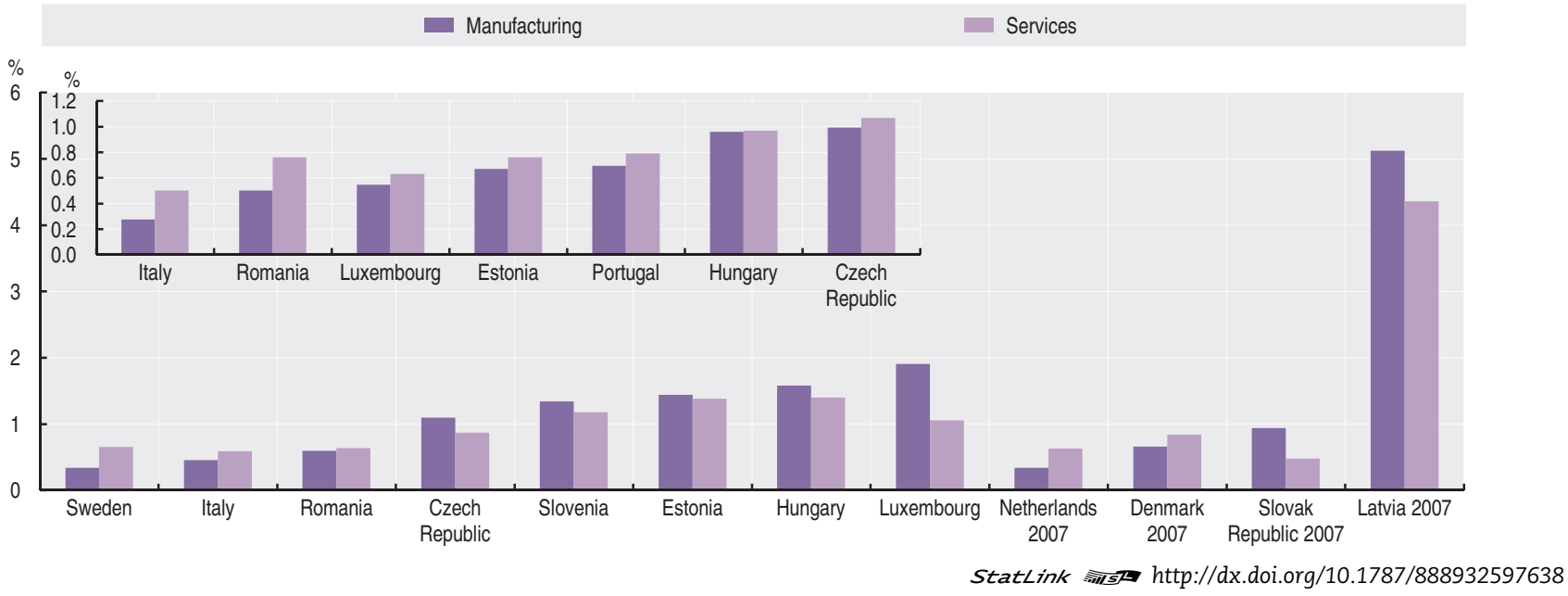





\section{WOMEN ENTREPRENEURSHIP}

Employers and own-account workers by gender

Share, size and industry of women-owned enterprises

Employment in women-owned enterprises

Birth and death rates of women-owned enterprises

Survival and employment growth of women-owned enterprises

Women on company boards 


\section{Employers and own-account workers by gender}

The relatively low rates of entrepreneurial activity among women represent a key concern for policy, since they signal a clear under-utilisation of entrepreneurial human capital. It is informative for policy makers to have distinct information on women and men employers (self-employed who employ others) and women and men own-account workers (self-employed working on their own). The first category is more likely to represent entrepreneurs.

\section{Definition}

The number of women employers is given by the number of women who report a professional status of "selfemployed with employees" in population surveys. The number of women own-account workers is given by the number of women who report a professional status of "self-employed without employees". The share of women employers is given by the number of women employers over the total number of employed women. The share of women own-account workers is given by the number of women own-account workers over the total number of employed women. The same indicators are calculated for self-employed men.

Self-employment jobs are those "jobs where the remuneration is directly dependent upon the profits (or the potential for profits) derived from the goods and services produced (where own consumption is considered to be part of profits). The incumbents make the operational decisions affecting the enterprise, or delegate such decisions while retaining responsibility for the welfare of the enterprise" (15th ILO Conference of Labour Statisticians, January 1993). Both unincorporated and incorporated self-employed women and men are included when the information is available.

\section{Comparability}

The main comparability issue relates to the classification of the incorporated self-employed. While in official statistics of most OECD countries, the self-employed who incorporated their businesses are counted as self-employed, in some countries such as Australia and the United States they are counted as employees. To improve international comparability, the number of incorporated employers and own-account workers in the United States was estimated, using information on the percentage of incorporated selfemployed men and women who have employees, available for 1995, 1997, 1999, 2001, 2005 from the Contingent and Alternative Work Arrangements Surveys. For the missing years between 1996 and 2004, this percentage has been derived through linear interpolation. For the years 2006 to 2011, the percentage for 2005 has been used.

\section{Highlights}

Women are significantly under-represented in the population of employers. The gender differences are relatively lower when looking at the population of own-account workers. In Europe and in the United States, the number of women employers has remained stable over the last decade, while the number of men employers has been slightly decreasing.

\section{Source/online databases}

Current Population Survey (United States), www.census.gov/cps/.

Economically Active Population Survey (Korea), http://kostat.go.kr/portal/english/news/1/2/index.board.

Encuesta Nacional del Empleo (Chile), www.ine.cl/boletines/detalle.php?id=2\&lang=.

Encuesta National de Empleo (Mexico), www.inegi.org.mx/est/contenidos/proyectos/encuestas/hogares/ default.aspx.

Eurostat Labour Force Surveys, 2000-2010, http://epp.eurostat.ec.europa.eu/portal/page/portal/microdata/lfs.

Labour Force Survey (Canada), www.statcan.gc.ca/imdb-bmdi/3701-eng.htm.

Labour Force Survey (Israel), www.cbs.gov.il/ts/databank/ databank_main_func_e.html? $i=21 \& t i=11 \& r=0 \& f=3 \& 0=0$.

Labour Force Survey (Japan), www.e-stat.go.jp/SG1/estat/eStatTopPortalE.do.

Labour Force Survey (South Africa), http://interactive.statssa.gov.za:8282/webview/.

National Household Sample Survey (Brazil), www.ibge.gou.br/english/estatistica/populacao/trabalhoerendimento/pnad2008/default.shtm\#brasil.

\section{For further reading}

Hipple, S. (2010), "Self-employment in the United States", Monthly Labor Review, September 2010.

OECD (2000), "Employment Outlook 2000”, OECD Publishing. 


\section{WOMEN ENTREPRENEURSHIP}

\section{Employers and own-account workers by gender}

Figure 7.1a Share of women and men employers, 2010 Percentage

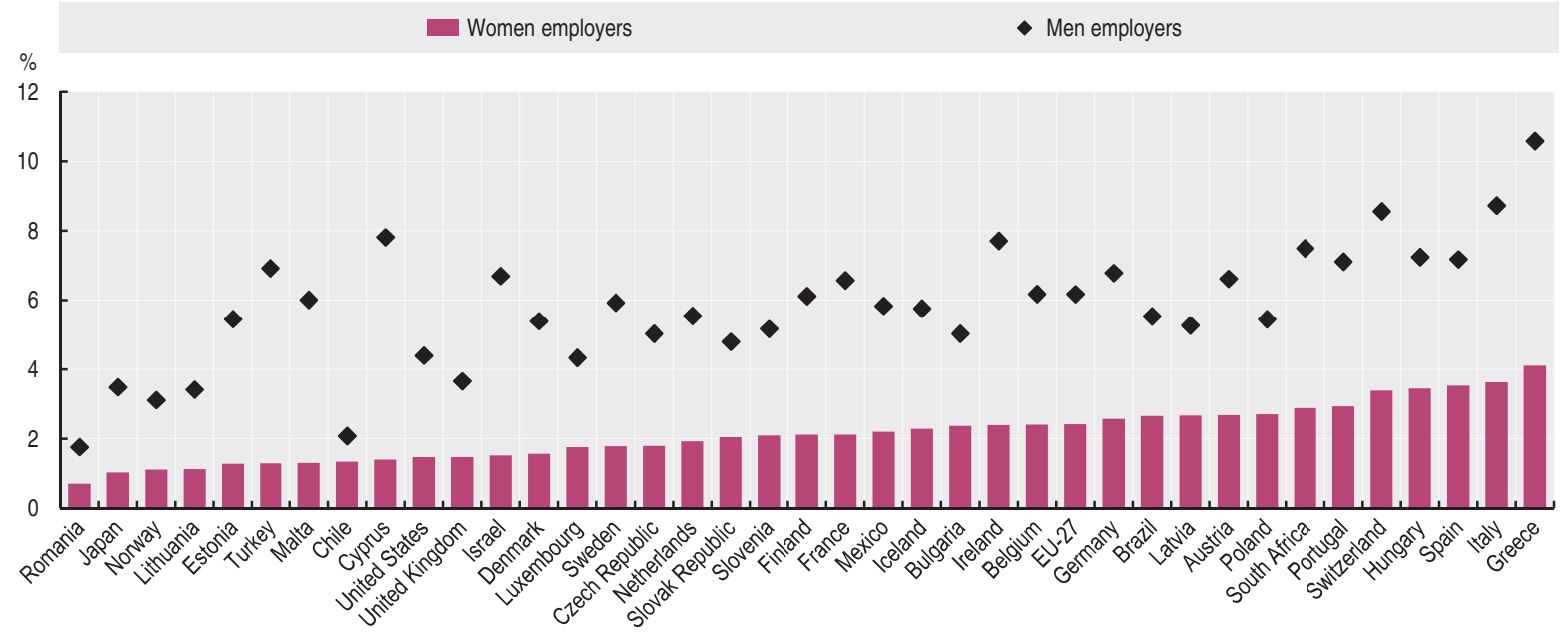

StatLink क्ञाs http://dx.doi.org/10.1787/888932597657

Figure 7.1b Share of women and men own-account workers, 2010 Percentage

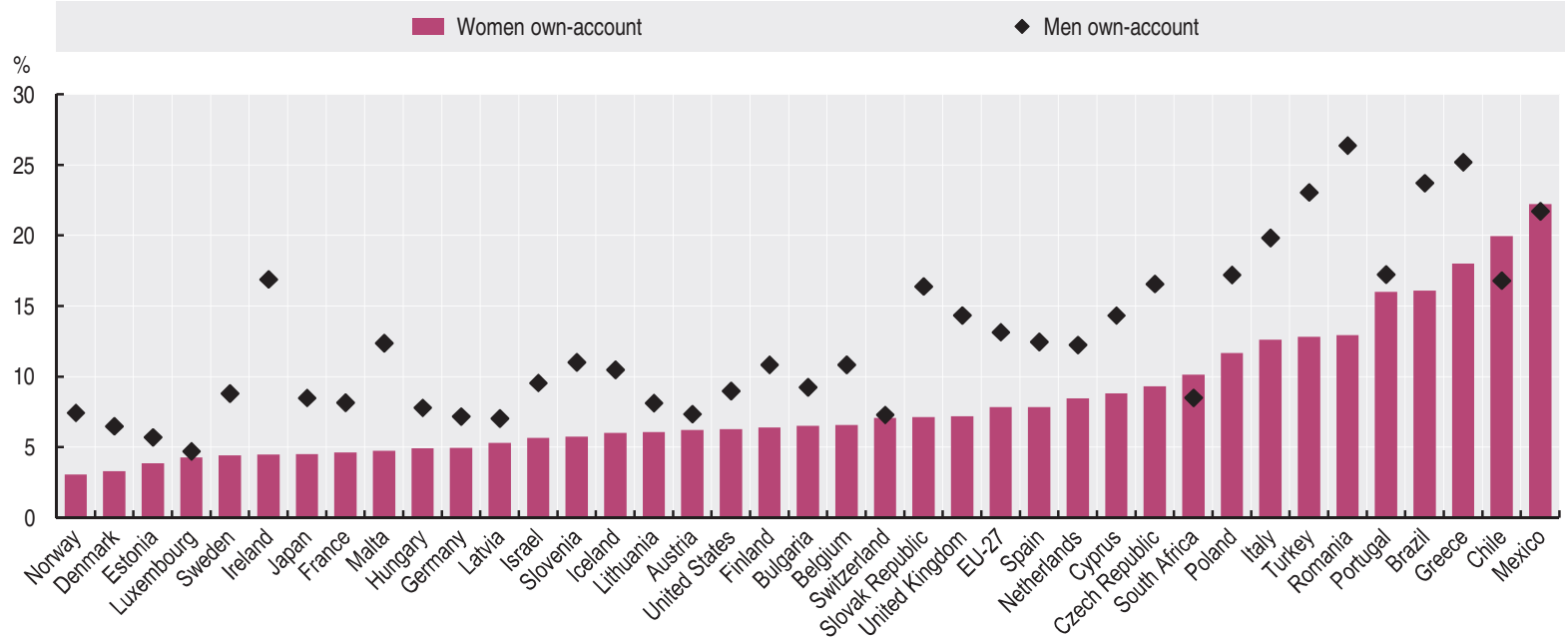

StatLink तiाst $h t t p: / / d x . d o i . o r g / 10.1787 / 888932597676$

Figure 7.2 Number of women and men employers in EU-27 and the United States Thousands

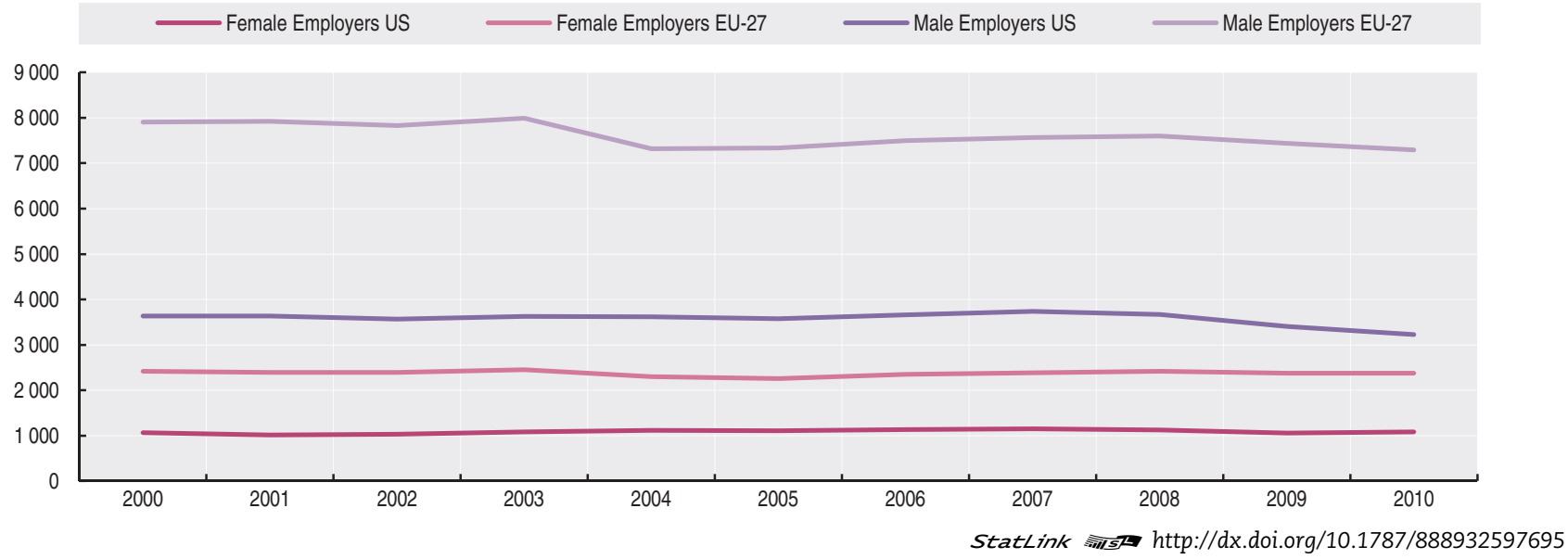




\section{Share, size and industry of women-owned enterprises}

Statistics on the share, size and industry distribution of women and men-owned enterprises provide key information on gender differences in entrepreneurship. They enable comparisons of the economic importance of women-owned enterprises across countries and over time. Moreover, they show how women entrepreneurs tend to own relatively smaller enterprises and select different industries with respect to men. The statistics have been primarily obtained by linking business registers to population registers or other administrative data. They are limited to sole-proprietor enterprises given the complexity of classifying enterprises with more than one owner along gender lines.

\section{Definition}

The share of sole-proprietor women-owned enterprises indicates the proportion of sole-proprietor enterprises who are owned by women. The size distribution of women and men-owned sole-proprietor enterprises indicates the proportion of women and men-owned enterprises in three size classes of number of persons employed (1-4, 5-9, 10 or more). The sole-proprietor is excluded from the count of the number of persons employed. The distribution of women and men-owned sole-proprietor enterprises by industry shows the proportion of women and men-owned enterprises in three aggregations of industrial activities. The first aggregation "Manufacturing, Mining and Utilities" includes NACE Rev. 2 (ISIC Rev. 4) sections B to E, the second aggregation "Trade, Transportation and Accommodation" includes NACE Rev. 2 (ISIC Rev. 4) sections G to I, the third aggregation "Professional and Support services" includes NACE Rev. 2 (ISIC Rev. 4) sections M and $\mathrm{N}$.

Sole-proprietor enterprises are unincorporated enterprises with one single owner - female or male - who is a person with unlimited responsibilities over losses and debts of the enterprise. Statistics refer to soleproprietorships with at least one employee.

\section{Comparability}

Different legal definitions of sole-proprietor enterprises and different economic incentives for incorporation can limit comparability across countries. The size distribution of sole-proprietor enterprises might be affected by country regulation. In New Zealand, for example, if a business reaches a reasonable size, financial advisers recommend setting up a limited liability company to continue the business. For the Netherlands, data are not available for NACE Rev. 2 letters P, Q, R and S. Data for Norway refer to 2010 and data for Mexico refer to 2008.

For Japan, the figures refer to the number of men and women sole-proprietors with and without employers, and not to women and men-owned sole-proprietor enterprises. Japanese data are thus not fully comparable to other countries, given that one single sole-proprietor can own more than one enterprise. Korea uses establishments instead of enterprises as the statistical unit.

\section{Highlights}

The proportion of sole-proprietor enterprises which are owned by women is comprised between 20 and $40 \%$. The average size is significantly lower for women enterprises in all countries, with the exception of Sweden. The proportion of women enterprises is relatively higher in wholesale and retail trade, transportation and accommodation, while it is relatively lower in manufacturing.

\section{Source/online databases}

Statistics produced for the OECD by national statistical offices.

Statistics Norway (2011), "Ownership and roles in business enterprise sector", www.sbb.no/eigazskap_en.

\section{For further reading}

Eurostat/OECD (2007), Eurostat-OECD Manual on Business Demography Statistics, OECD Publishing.

OECD (2004), Women Entrepreneurship, Issues and Policies, OECD Publishing. 
Figure 7.3 Share of sole-proprietor women-owned enterprises, 2009 or latest available year

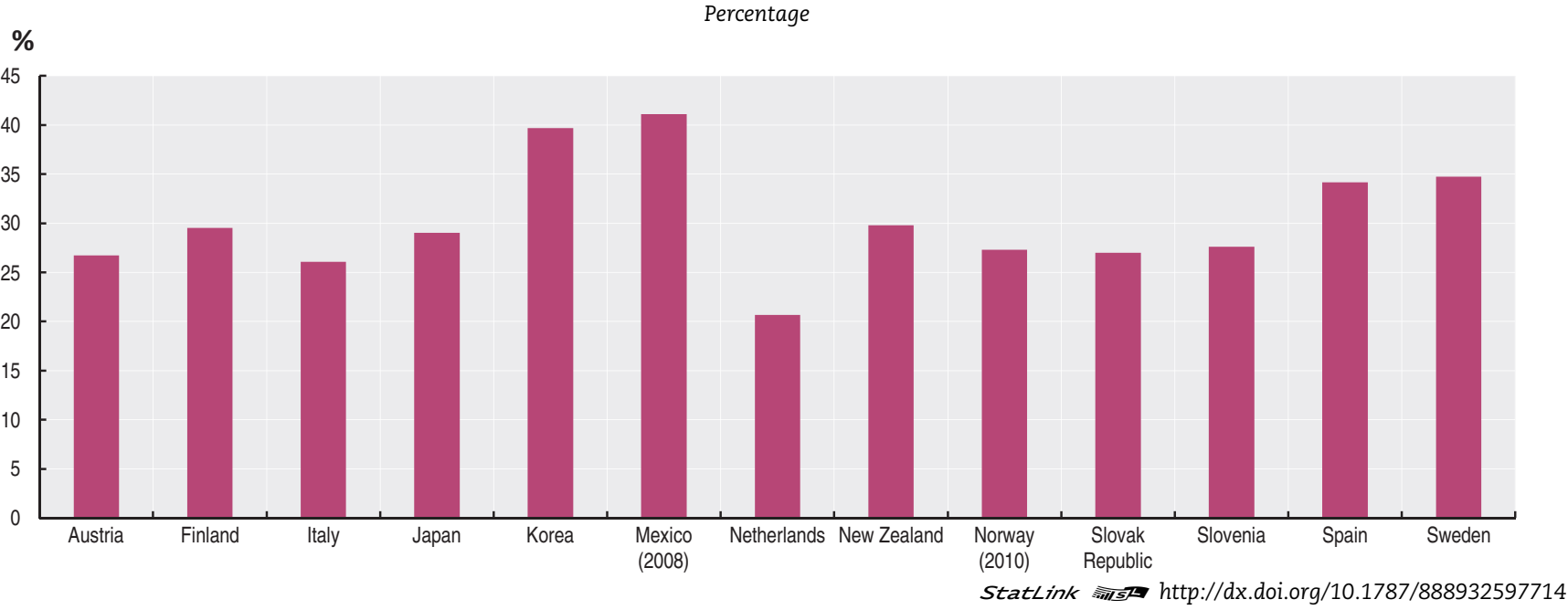

Figure 7.4 Size distribution of women and men-owned sole-proprietor enterprises, 2009 or latest available year Percentage

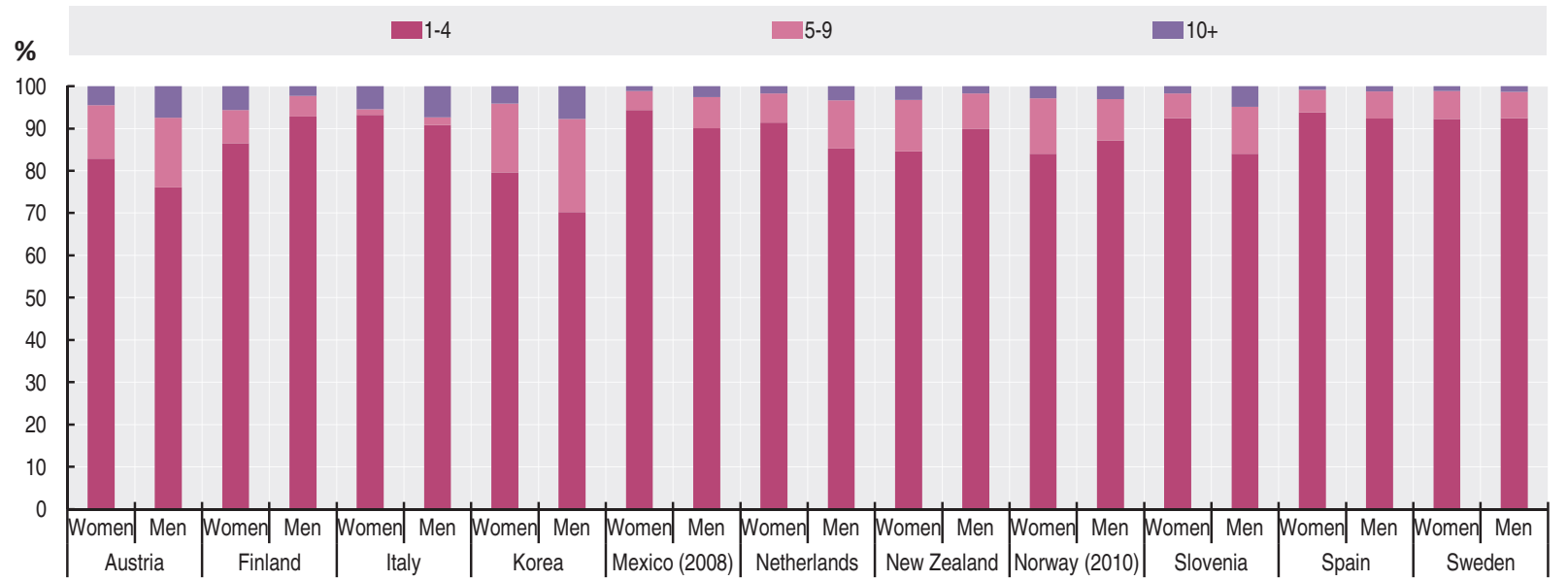

StatLink तोs काtp://dx.doi.org/10.1787/888932597733

Figure 7.5 Distribution of women and men-owned sole-proprietor enterprises by industry, 2009 or latest available year Percentage
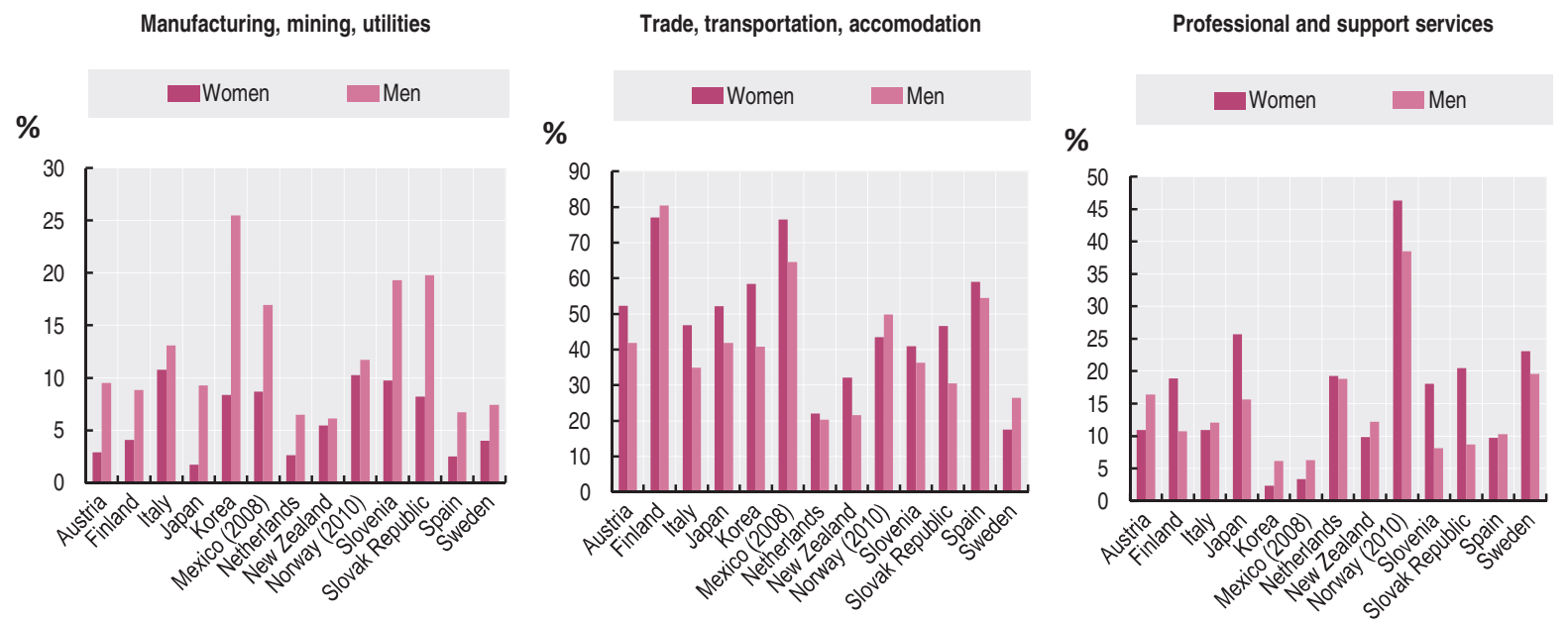

StatLink तारास http://dx.doi.org/10.1787/888932597752 


\section{Employment in women-owned enterprises}

The contribution of women-owned enterprises to employment creation is still poorly documented. Comparable data on employment in women and men-owned enterprises provide indications about the relative contribution of enterprises held by women to job creation. The breakdown by size classes compares the capacities of differently sized women-owned enterprises to generate employment.

\section{Definition}

The share of persons employed in sole-proprietor enterprises by gender of the owner indicates the proportion of persons employed working in women (men) sole-proprietorships. The distribution of employment by gender of the owner and size shows how employment is distributed across women and men-owned enterprises with 1-4, $5-9$, and 10 or more persons employed.

Sole-proprietor enterprises are unincorporated enterprises with one single owner - female or male - who is a natural person with unlimited responsibilities over losses and debts of the enterprise. A woman (man)owned sole-proprietorship is an enterprise whose sole proprietor is a woman (man). Statistics refer to soleproprietorships with at least one employee.

\section{Comparability}

Different legal definitions of sole-proprietor enterprises and different economic incentives for incorporation can limit comparability of the absolute number of sole-proprietor enterprises across countries. The size distribution of sole-proprietor enterprises might be affected by country regulation. In New Zealand, if a business reaches a reasonable size, financial advisers recommend setting up a limited liability company to continue the business.
For the Netherlands, data are not available for NACE letters P, Q, R, S. Data for Mexico refer to 2008.

For Japan, employment figures refer to the number of person employed by men and women sole-proprietors, and not by women and men sole-proprietor enterprises. Japanese figures are thus not fully comparable to other countries, given that one single sole-proprietor can own more than one enterprise.

All countries present information using the enterprise as the statistical unit, with the exception of Korea which uses establishments.

\section{Highligths}

A significant share of the persons working for soleproprietor enterprise are employed by women. More than $50 \%$ of the employment is in the lowest size class (1 to 4 persons employed) of women-owned enterprises.

\section{Source/online databases}

Statistics produced for the OECD by national statistical offices.

\section{For further reading}

OECD (2010), "Structural and Demographic Business Statistics", OECD Publishing, http://dx.doi.org/10.1787/9789264072886-en.

OECD (2001), "Issues related to Statistics on Women's Entrepreneurship", Paper presented at the Workshop on Firm-level Statistics, 26-27 November 2001. 
Figure 7.6 Share of persons employed in sole-proprietor enterprises by gender of the owner, 2009 or latest available year Percentage

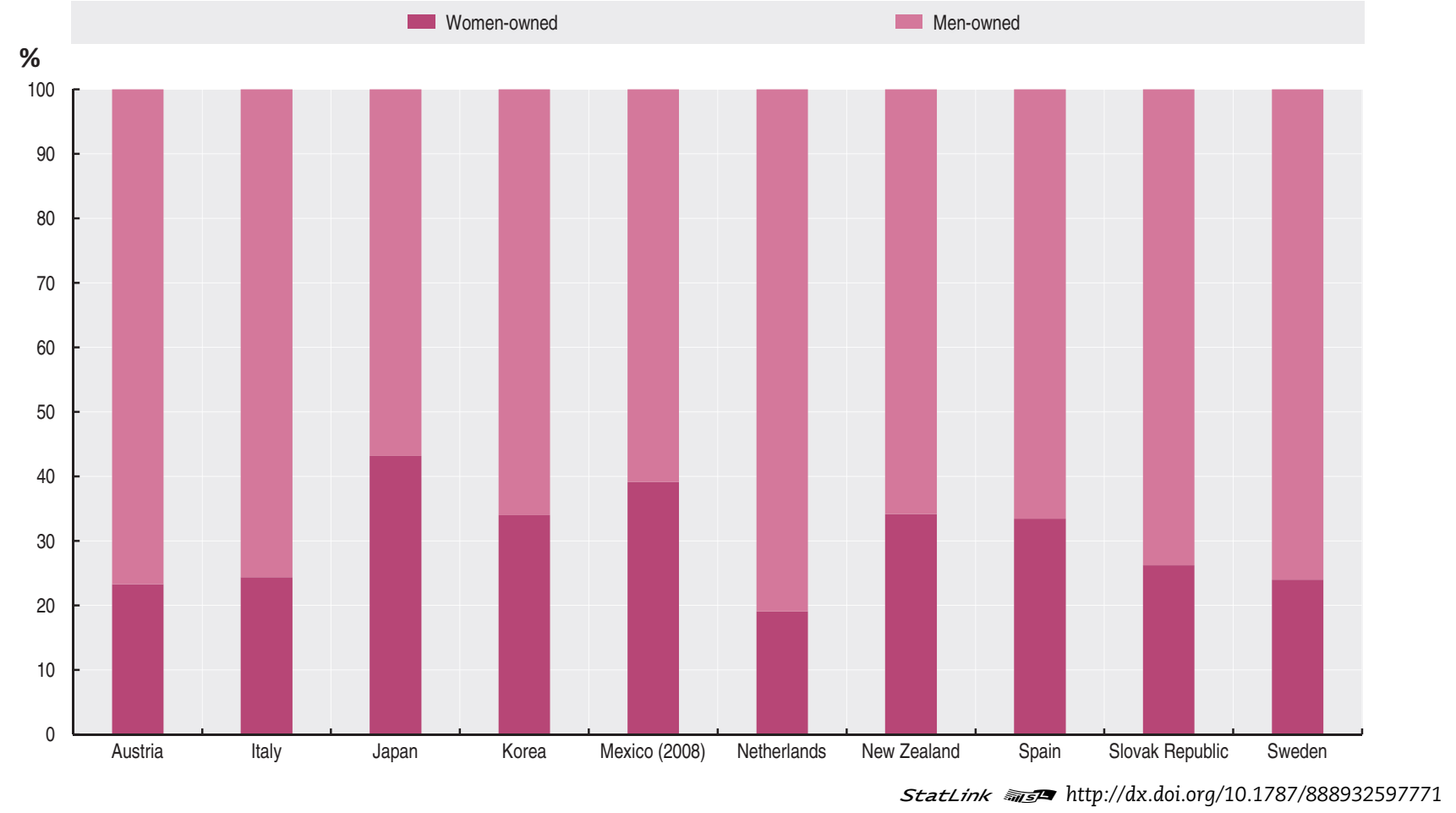

Figure 7.7 Distribution of employment in sole-proprietor enterprises by gender of the owner and size, 2009 or latest available year

Percentage

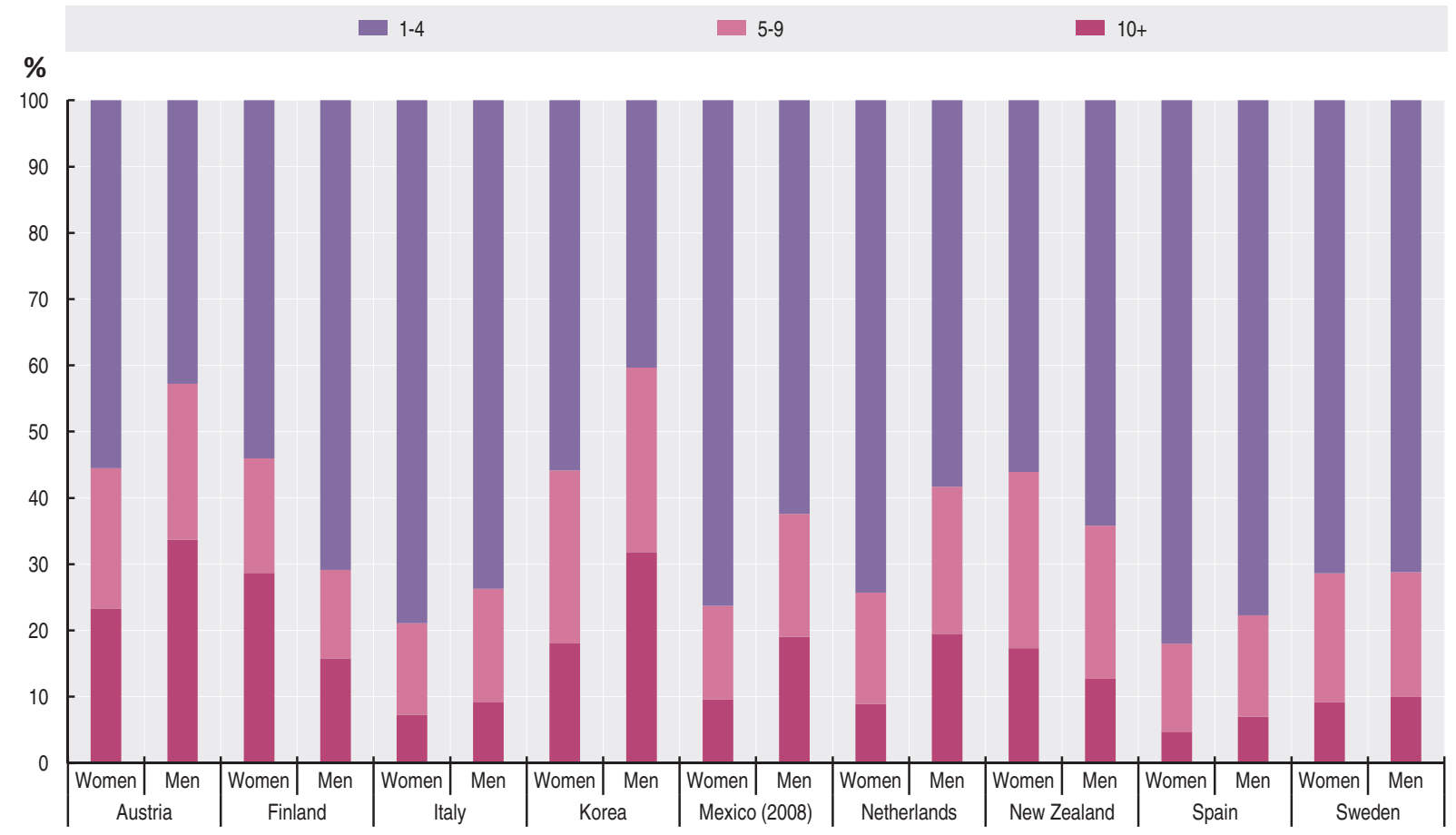

StatLink ताst http://dx.doi.org/10.1787/888932597790 


\section{WOMEN ENTREPRENEURSHIP}

\section{Birth and death rates of women-owned enterprises}

The birth rate of women-owned enterprises provides essential information about the dynamism of women's entrepreneurship. Statistics on births and deaths, together with information on related employment generation and destruction, can tell whether the economic weight of women entrepreneurs is converging to the one of men. They can also inform about the effects of economic downturns on the dynamics of women and men entrepreneurship.

\section{Definition}

The employer birth rate of women (men)-owned sole-proprietor enterprises corresponds to the number of births of women (men)-owned employer sole-proprietor enterprises as a percentage of the population of active soleproprietorships with at least one employee.

The employer death rate of women (men)-owned sole-proprietor enterprises corresponds to the number of deaths of women (men)-owned employer sole-proprietor enterprises as a percentage of the population of active sole-proprietorships with at least one employee.

Sole-proprietor enterprises are unincorporated enterprises with one single owner - female or male - who is a person with unlimited responsibilities over losses and debts of the enterprise. Statistics refer to soleproprietorships with at least one employee.

\section{Comparability}

Different legal definitions of sole-proprietor enterprises and different economic incentives for incorporation can limit comparability of the absolute number of sole-propri- etor enterprises across countries. Data refer to 2009, with the exception of the death rate for Italy, the Netherlands, Slovak Republic and Sweden referring to 2008.

All countries present information using the enterprise as the statistical unit, with the exception of Korea which uses establishments.

\section{Highligths}

Births and deaths are lower in absolute numbers for women than for men-owned enterprises. However, the birth rate of women-owned enterprises is higher than that of men-owned ones, indicating an acceleration in the creation of new enterprises by women. The death rates of women-owned enterprises have been lower in some countries (Italy, New Zealand, Spain and Sweden), but higher in others (Austria, Finland and Slovak Republic).

\section{Source/online databases}

Statistics produced for the OECD by national statistical offices.

\section{For further reading}

Boegh Nielsen, P., (2001), "Statistics on Start-ups and Survival of Women Entrepreneurs: the Danish Experience" in Women Entrepreneurs in SMEs, Realising the Benefits of Globalisation and the Knowledge-based Economy, OECD Publishing.

Ahmad N. and A. Hoffman, (2008), "A Framework for Addressing and Measuring Entrepreneurship," OECD Statistics Working Papers 2008/2, OECD Publishing. 
Figure 7.8 Employer birth rate of women and men-owned sole-proprietor enterprises, 2009 or latest available year Percentage

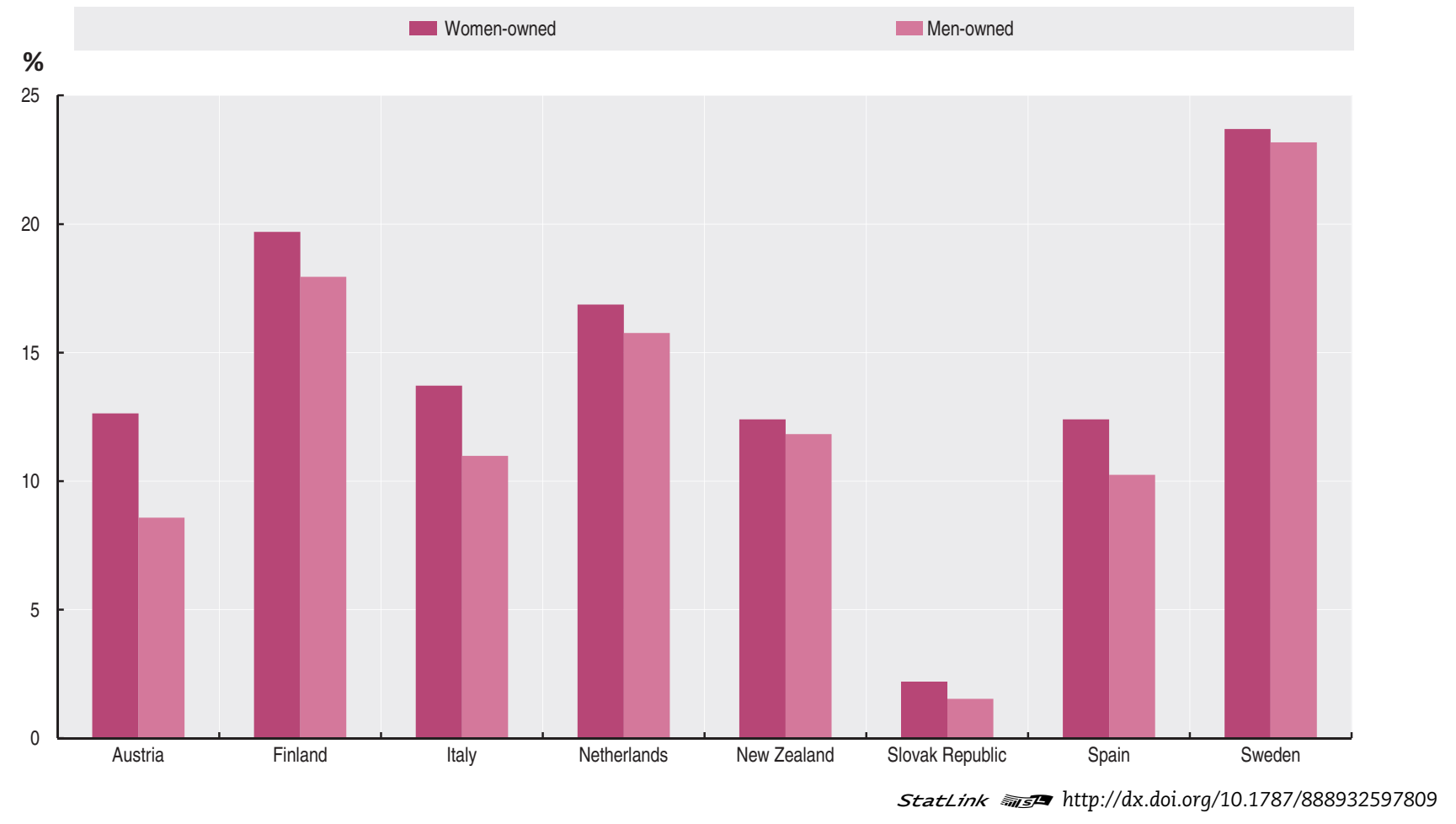

Figure 7.9 Employer death rate of women and men-owned sole-proprietor enterprises, 2009 or latest available year Percentage

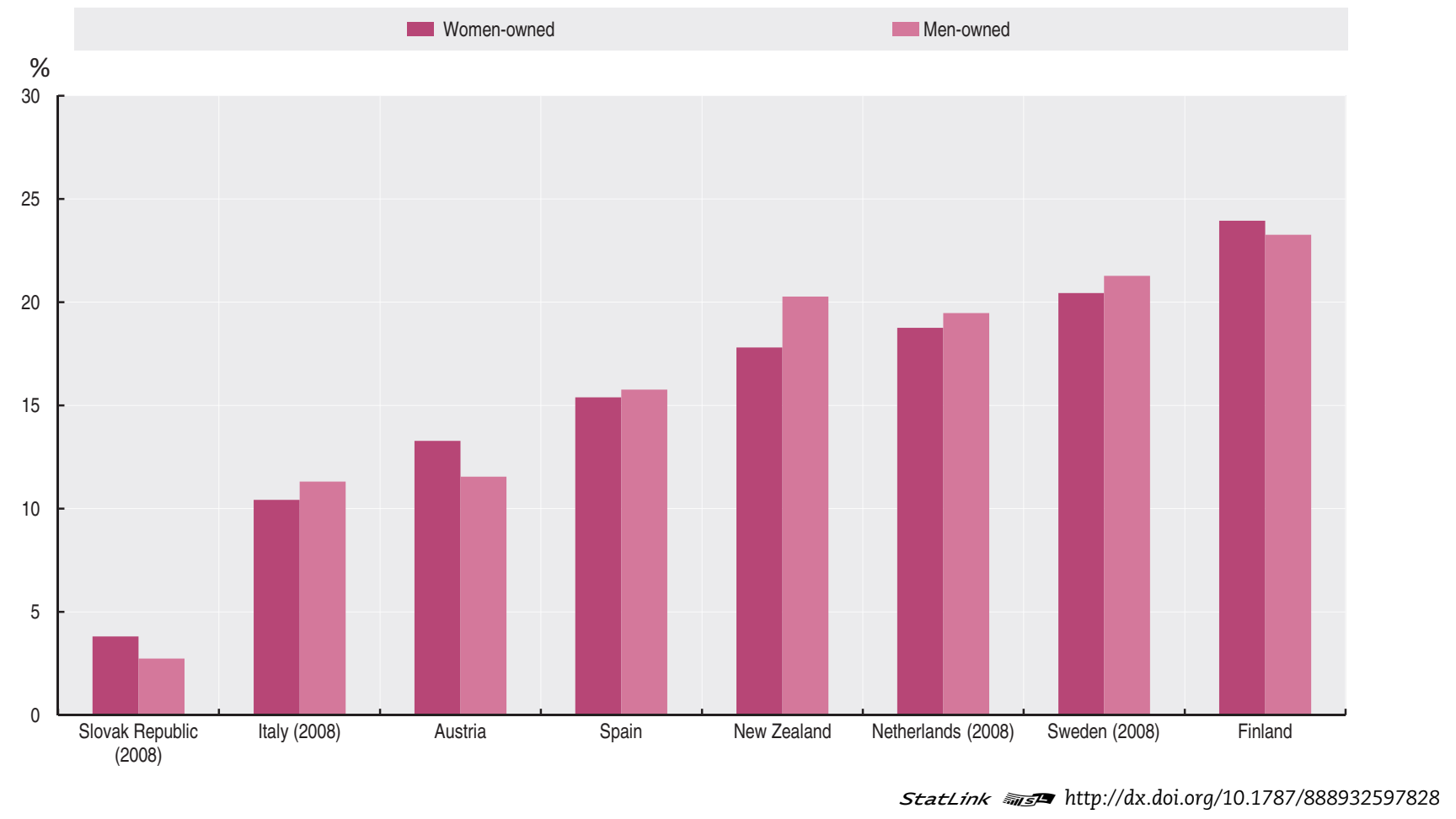




\section{Survival and employment growth of women-owned enterprises}

Policy makers can monitor the relative performance of women-owned enterprises by looking at their rate of survival and at their capacity to generate jobs during the first years of activity. Gender-disaggregated indicators on survival and employment growth allow to investigate questions such as the resilience and the growth performance of women-owned enterprises.

\section{Definition}

The three-year survival rate of women (men)-owned enterprises for a reference year $t$ is calculated as the number of women (men) enterprises having survived up to $t$ as a percentage of all women (men) enterprises that reported at least one employee for the first time in year $\mathrm{t}-3$.

The three-year employment growth rate of women (men)owned enterprises corresponds to the number of persons employed in surviving women (men)-owned enterprises in the reference year $t$ divided by the number of persons employed in the year of birth $t-3$ of those same women (men) enterprises that have survived to $\mathrm{t}$.

Sole-proprietor enterprises are unincorporated enterprises with one single owner - female or male - who is a person with unlimited responsibilities over losses and debts of the enterprise. Statistics refer to soleproprietorships with at least one employee.

\section{Comparability}

Different legal definitions of sole-proprietor enterprises and different economic incentives for incorporation can limit the comparability of the absolute number of sole-proprietor enterprises across countries.

Data from France, Poland and Switzerland are obtained from representative surveys of new enterprises. They are tabulated by gender of the enterprise (sole) founder instead of by gender of the sole-proprietor. The cohort of enterprise births from these surveys does not include those enterprises born by growth, i.e. enterprises that existed before the year under consideration but were below the threshold of one employee. For Switzerland, the employer status of the enterprises is defined according to whether they have employees at the date of the survey. Statistics for Switzerland refer to two-year survival rate and employment growth rate in 2008. Statistics for Poland are limited to enterprise entities up to 49 employees. The data for France and Poland include enterprises born with and without employees.

\section{Highligths}

The evidence on gender differences in the survival rates is not clearcut. In most countries, women and men start-ups tend to have a similar survival performance three years after the birth. Performance in terms of employment creation during the first years of operation tends to vary greatly across countries, with women-owned new enterprises outperforming men-owned enterprises in France, Italy, New Zealand and Poland, while lagging behind in Finland, the Netherlands, Slovak Republic and Switzerland.

\section{Source/online databases}

Statistics produced for the OECD by national statistical offices.

Statistics for France: "Système d'information sur les nouvelles entreprises (SINE)", www.insee.fr/fr/themes/document.asp?ref_id=sine2009

\section{For further reading}

Letowski, A., (2001), "Comment améliorer la connaissance statistique des femmes chefs d'entreprise?", in "Women Entrepreneurs in SMEs, Realising the Benefits of Globalisation and the Knowledge-based Economy", OECD Publishing.

Boegh Nielsen, P., (2001), "Statistics on Start-ups and Survival of Women Entrepreneurs: the Danish Experience" in Women Entrepreneurs in SMEs, Realising the Benefits of Globalisation and the Knowledge-based Economy, OECD Publishing. 


\section{WOMEN ENTREPRENEURSHIP}

\section{Survival and employment growth of women-owned enterprises}

A corrigendum has been issued for this page. See http://www.oecd.org/about/publishing/Corrigendum_EAG.pdf Figure 7.10 Three-year survival rate of women and men-owned enterprises, 2009 or latest available year Percentage

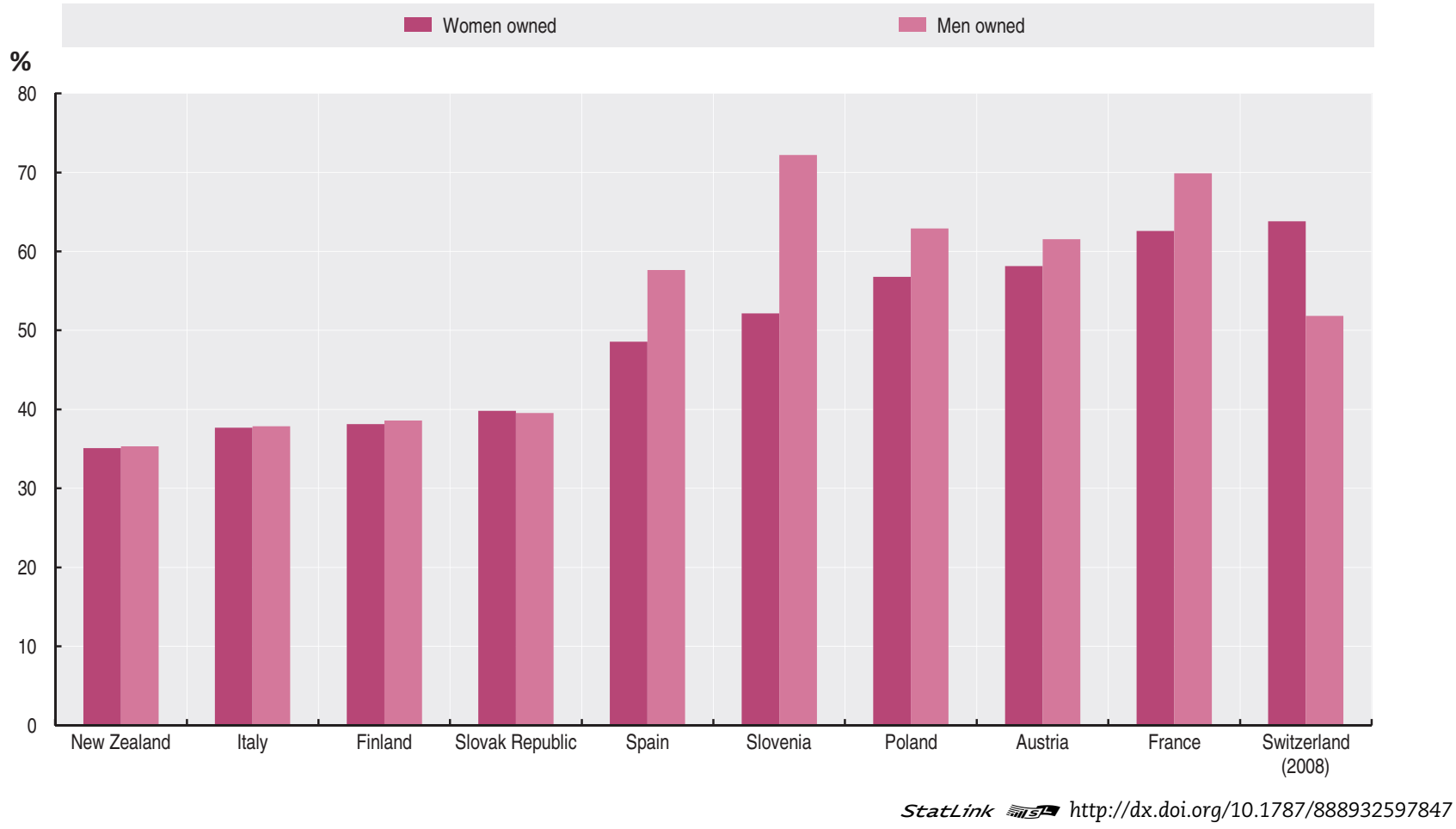

Figure 7.11 Three-year employment growth rate of women and men-owned enterprises, 2009 or latest available year

Women-owned Men-owned

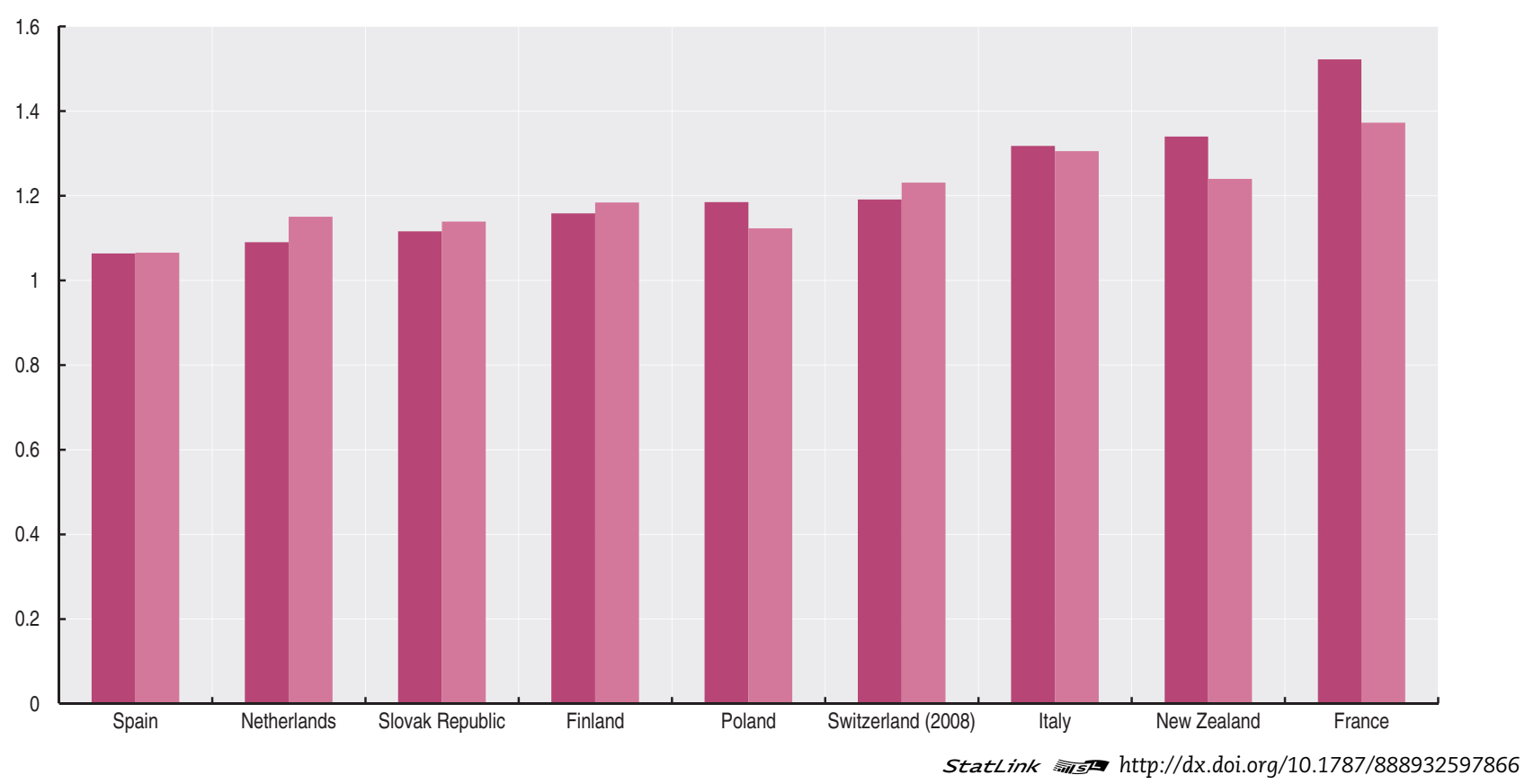


The low presence of women on company boards is often cited as a signal of the obstacles women face in climbing the corporate ladder. Several countries are considering the introduction of quotas, to enforce a minimum level of representation of women on corporate boards.

\section{Definition}

The share of women on company boards is derived by calculating country-averages of the percentages of women among the members of the board of directors of each company in the OECD ORBIS dataset. The calculation is restricted to companies with at least two board members. The share is derived also for the subset of listed companies.

The board gender diversity index is calculated as the inverse of a Herfindal index with two groups (1-(share of women ${ }^{2}+$ share of men $\left.^{2}\right)$ ). The index increases in the proportion of men and of women in the companies' boards, taking a value of 0 if the board is composed either exclusively by men or exclusively by women. The maximum value is 0.5 . The national value is an average for all the country's firms with at least two board members.

The gender of board members is available for most countries in the ORBIS dataset. In order to improve the identification of gender of the directors in the ORBIS raw data, an algorithm was developed that attributes the gender to the director on the basis of his/her first name. The statistics are produced for all countries for which at least one hundred valid observations are available. The median number of companies for the included countries is 22193.

\section{Comparability}

The main comparability issue is represented by the fact that the coverage of firms is still uneven across countries in the OECD ORBIS dataset. Large companies are generally over-represented, and this is particularly an issue in nonOECD countries.

\section{Highligths}

There is a great heterogeneity across countries in the representation of women among members of boards of directors. Within countries, differences are evident between listed and non-listed firms. Relatively low numbers of women in boards tend to translate in low levels of gender diversity of companies' boards. Norway, the first country having introduced a mandatory legal quota, scores high on both indicators.

\section{Source/online databases}

OECD ORBIS dataset.

\section{For further reading}

Adams, R. B. and D. Ferreira (2009), "Women in the boardroom and their impact on governance and performance", Journal of Financial Economics, Vol. 94 (2), pp. 291-309

OECD (2011), "Report on the Gender Initiative: Gender Equality in Education, Employment and Entrepreneurship", OECD, Paris, May. 


\section{WOMEN ENTREPRENEURSHIP}

Figure 7.12 Share of women on company boards, 2009

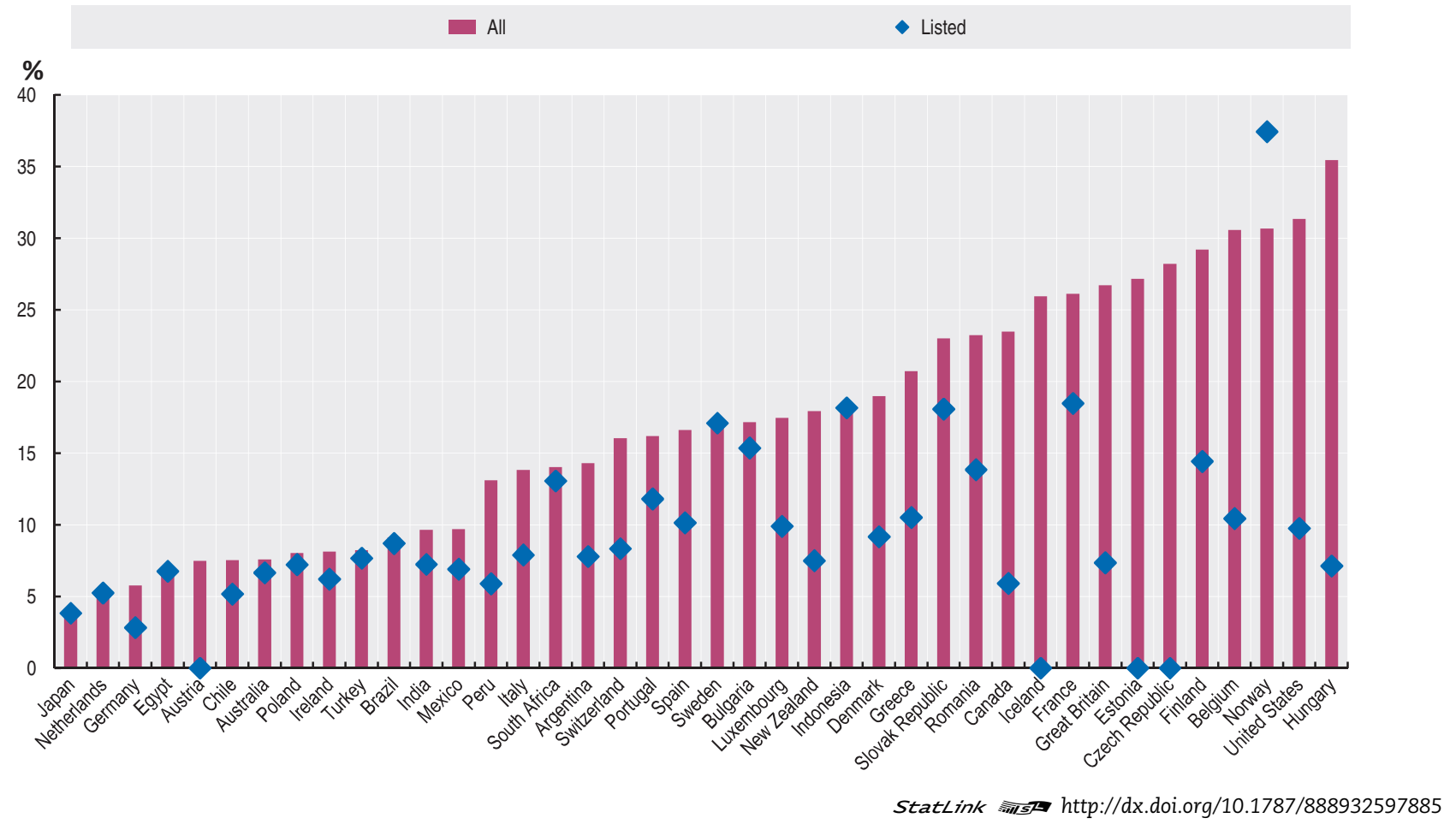

Figure 7.13 Board gender diversity index, 2009

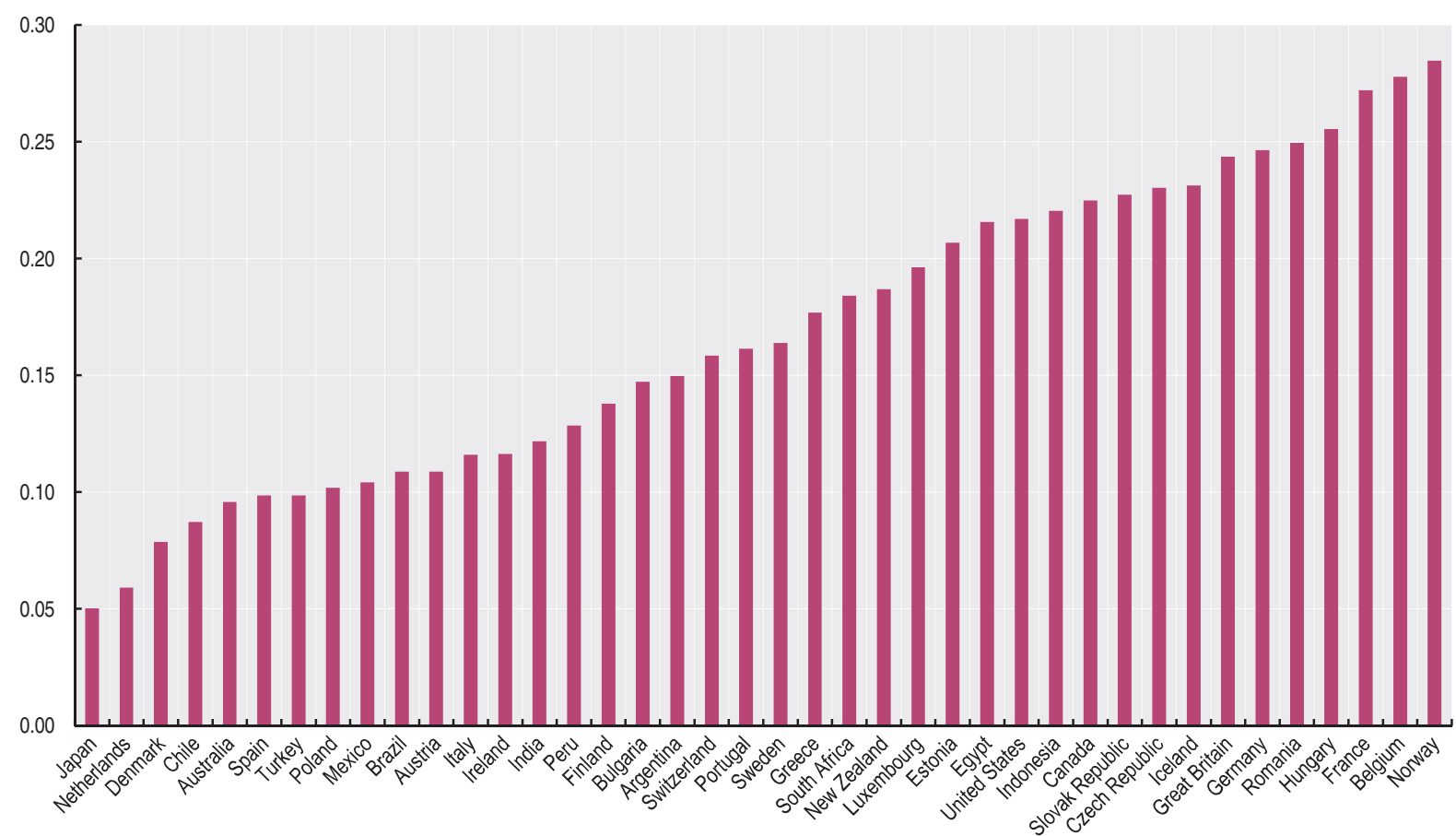

StatLink Aाs $\mathrm{http}: / / d x . d o i . o r g / 10.1787 / 888932597904$ 
4.46

30022818020

14. 500 180

क. 254.15 ? 10

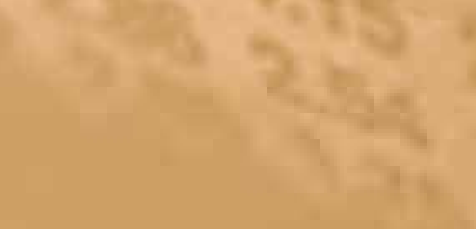

$\int_{1}$
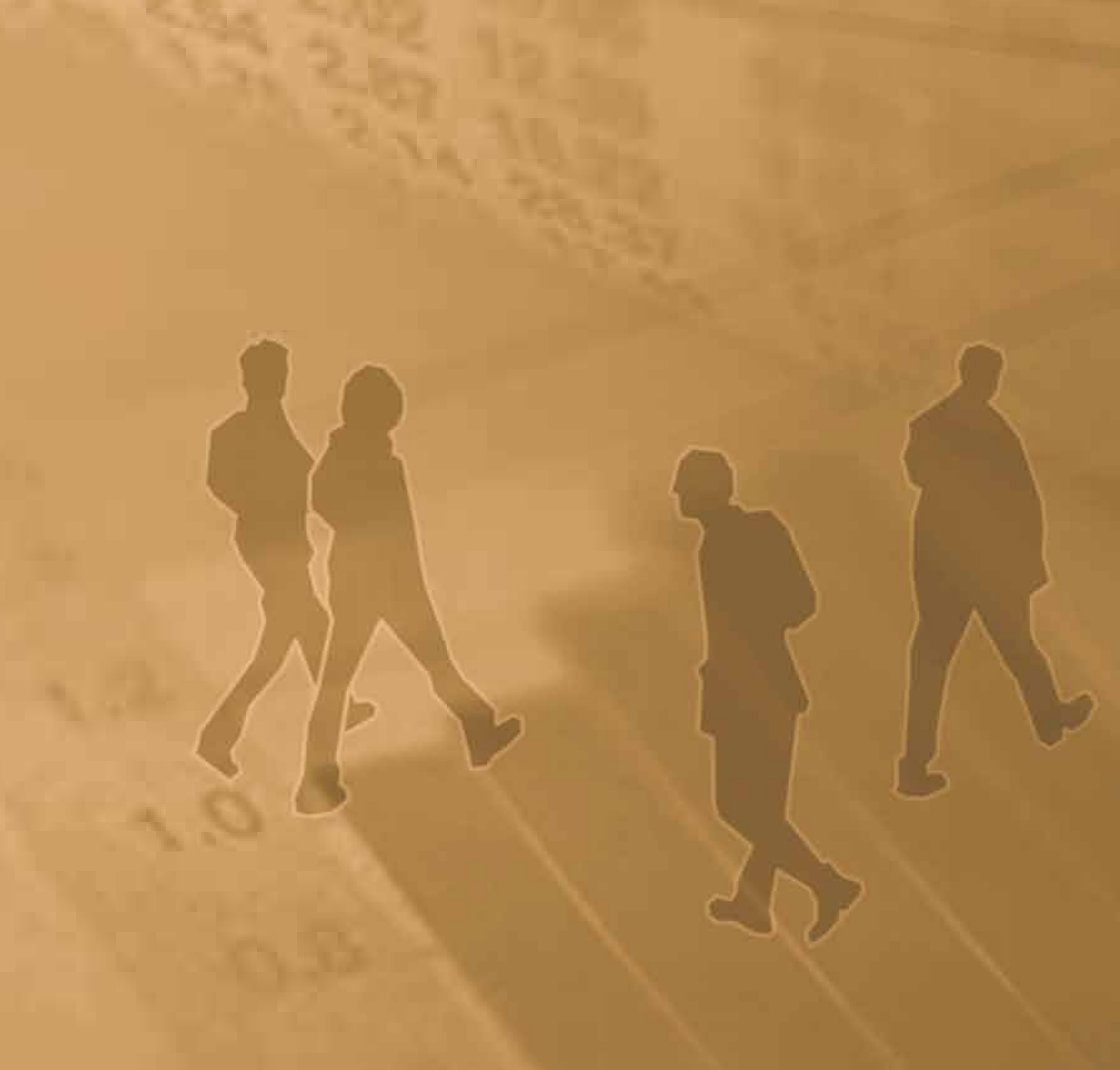


\section{DETERMINANTS OF ENTREPRENEURSHIP: SELECTED INDICATORS}

Regulatory framework: Starting a business

Access to finance: Success rate in obtaining finance

Culture: Entrepreneurial perceptions and attitudes 
A combination of opportunity, capabilities and resources does not necessarily lead to entrepreneurship if opportunity costs (e.g. forgone salary and loss of health insurance) and start-up costs outweigh the potential benefits. The regulatory framework is a critical factor affecting countries' entrepreneurial performance. While the regulatory framework, as broadly defined by the EIP, encompasses taxes, regulations and other public rules and institutions affecting entrepreneurship, this section focuses on measures of burden on the creation of new enterprises.

\section{Definition}

The indicator starting a business is a composite indicator measuring the procedures, time and costs necessary to register and operate a new business.

Four sub-indicators enter in the calculation of starting a business: "number of procedures to legally start and operate a company", "time required to complete each procedure (calendar days)", "cost required to complete each procedure (\% of gross national income per capita)", "paid-in minimum capital (\% of gross national income per capita)".

The total number of procedures required to register a firm: a procedure is defined as any interaction of the company founders with external parties (for example, government agencies, lawyers, auditors or notaries).

The total number of days required to register a firm: the measure captures the median duration that incorporation lawyers indicate is necessary to complete a procedure with minimum follow-up with government agencies and no extra-payments. It is assumed that the minimum time required for each procedure is one day and that simultaneous procedures cannot start on the same day.

\section{Comparability}

The indicators are drawn from the World Bank's 2012 Doing Business report. This is an annual publication based on a survey of domestic laws, regulations and administrative requirements. The publication provides quantitative measures of business regulation in the following areas: starting a business, dealing with construction permits, getting electricity, registering property, getting credit, credit information, protecting investors, paying taxes, trading across borders, enforcing contracts, resolving insolvency, and employing workers.

To increase comparability across countries, several assumptions are used on the reference business; the main assumptions include: the business is a limited liability company (or its legal equivalent), is located in the largest business city of the economy, has at least 10 up to 50 employees, is $100 \%$ domestically owned and its start-up capital is 10 times per capita gross national income of the economy.

The indicators presented refer to the data collection completed by the World Bank in 2011.

\section{Highligths}

The regulatory framework conditions for starting a business are more favourable in English-speaking countries. The number of procedures needed to create a limited liability company is low in almost all OECD countries, i.e. typically between 4 and 6 , although in Greece and Spain 10 different procedures are requested. There are more differences across OECD countries in terms of number of days needed for creating a business: only one and two days are necessary respectively in New Zealand and Australia, but almost 30 in Austria and Spain. Overall, the administrative burdens are still quite cumbersome in Brazil, China, India, Indonesia and the Russian Federation; South Africa is closer to the average levels.

\section{Sources/online databases}

World Bank Doing Business, www.doingbusiness.org/data

\section{For further readings}

World Bank, 2012 Doing Business, World Bank, Doing Business Methodology,

www.doingbusiness.org/methodology/starting-a-business.

OECD Indicators of Product Market Regulation, www.oecd.org/document/36/

0,3746,en_2649_34323_35790244_1_1_1_1,00.html.

Information on data for Israel:

http://dx.doi.org/10.1787/888932315602. 
Figure 8.1 Starting a business, 2011

Ranking of countries from least to more restrictive

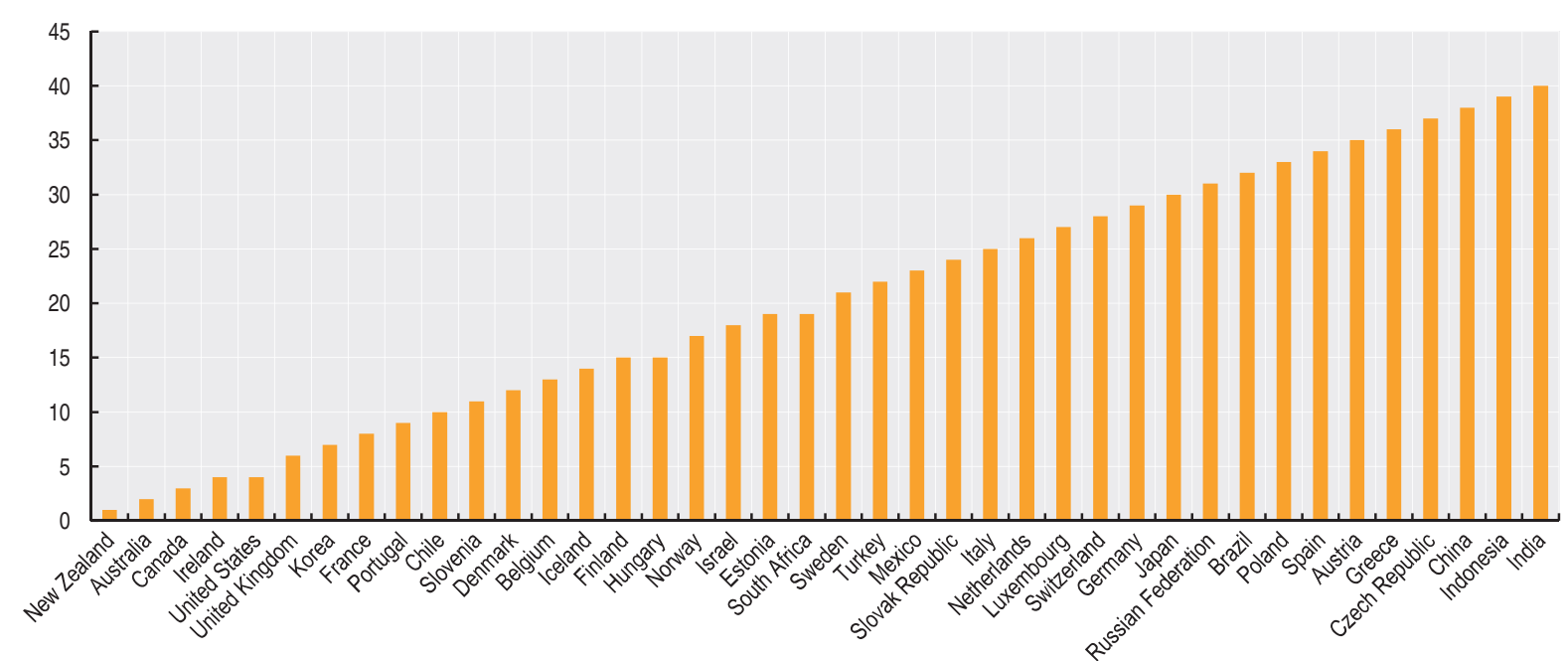

StatLink क्ञाड $h$ ttp://dx.doi.org/10.1787/888932597923

Figure 8.2 Number of procedures to start a business, 2011

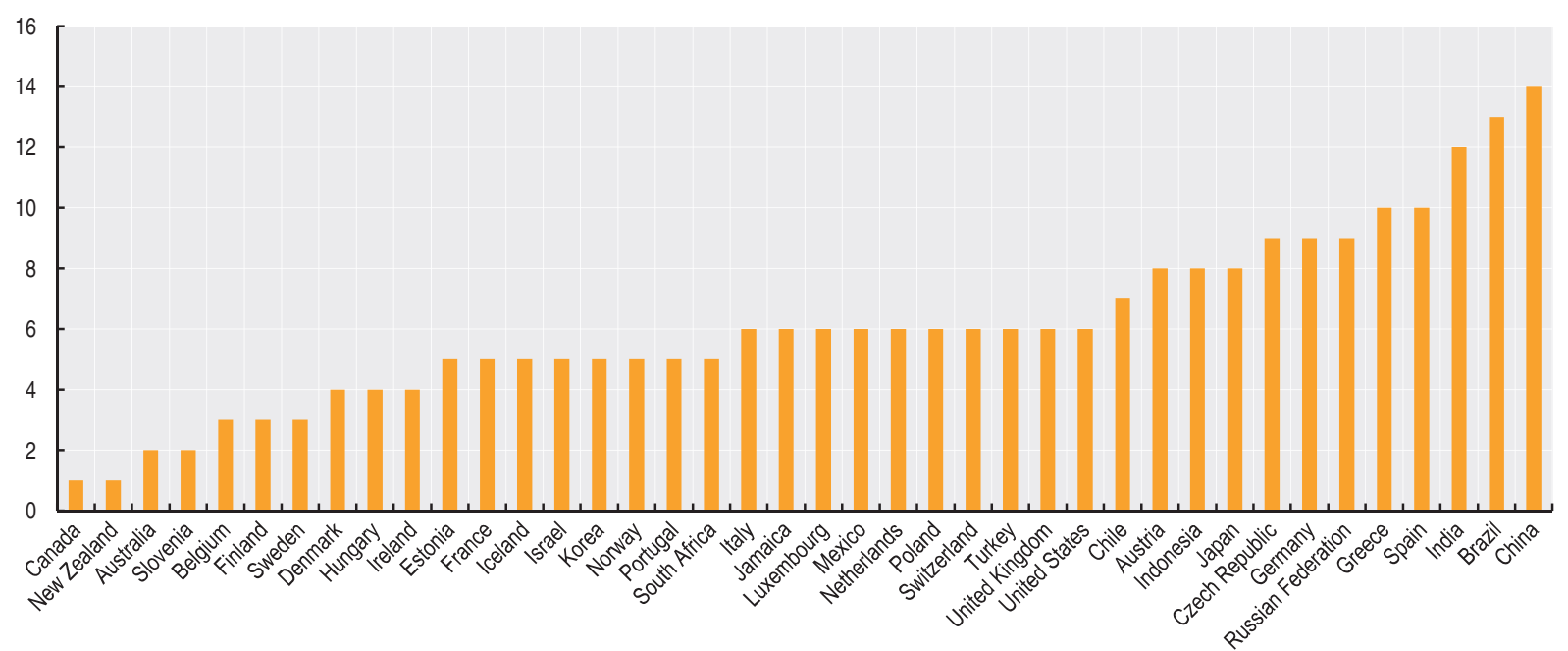

Figure 8.3 Number of days to start a business, 2011

StatLink तiाs http://dx.doi.org/10.1787/888932597942

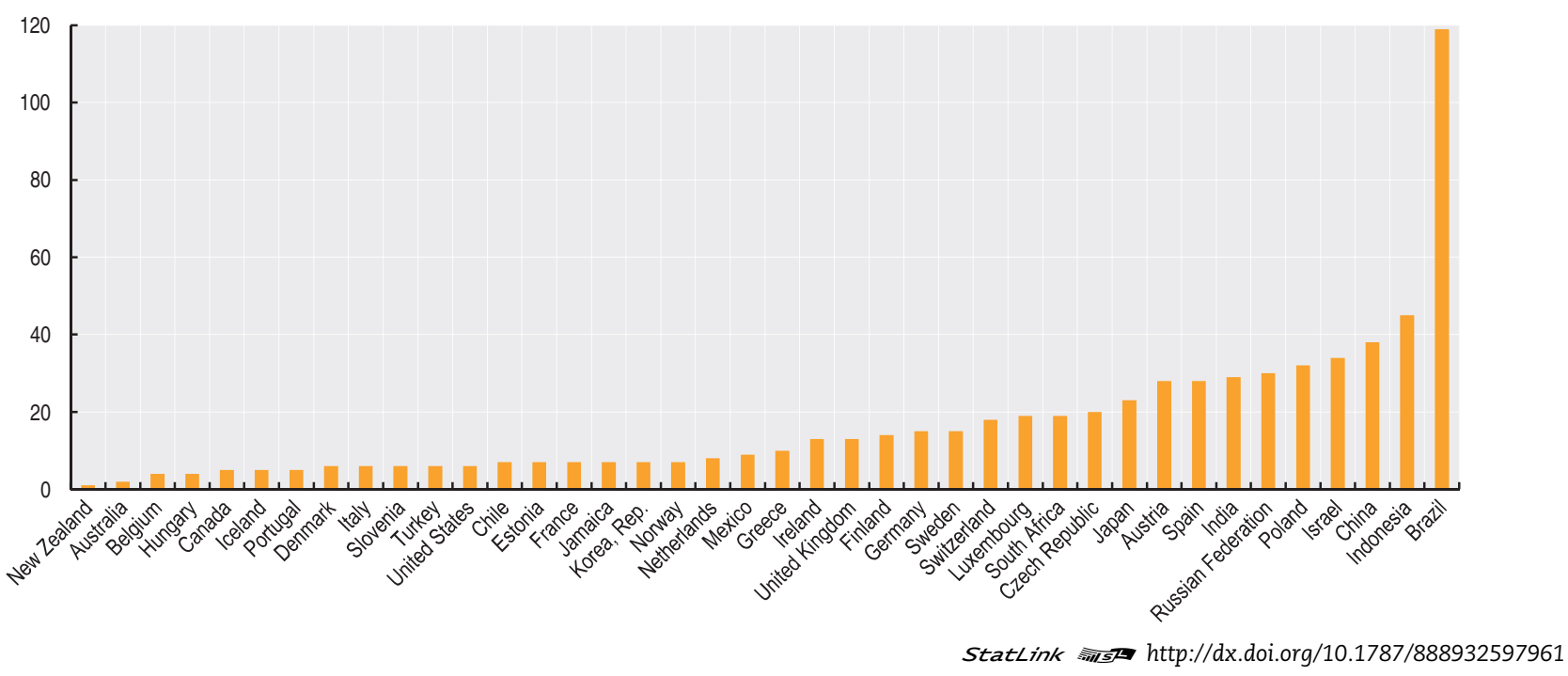


The ease to financial access is an important factor for starting and growing a business. Financing needs however vary between enterprises with different growth characteristics. The development of information about the sources most used by different types of enterprises and the responses they obtain to their requests of finance contributes to improve policy makers understanding of entrepreneurial finance and the difficulties faced by firms aiming at growing their business.

\section{Definition}

The indicators of success rate in obtaining finance show the percentage of approvals of financing requests made by small and medium-sized enterprises (SMEs) of: loans, equity finance, and other finance. For each of the three types, the indicators show the approval rate with respect to the principal source, i.e. respectively banks, existing shareholders, and leasing.

SMEs are defined as enterprises having between 10 and 249 employees.

Gazelles are enterprises that have been employers for a period of up to five years, with average annualised growth in employees greater than $20 \%$ a year over a three-year period and with ten or more employees at the beginning of the observation period.

Other high-growth enterprises are enterprises with average annualised growth in employees greater than $20 \%$ a year, over a three-year period, and with ten or more employees at the beginning of the observation period.

\section{Comparability}

Data are drawn from a survey on access to finance co-ordinated by Eurostat in 2010 in 20 European countries: Belgium, Bulgaria, Cyprus, Denmark, Finland, France,
Germany, Greece, Ireland, Italy, Latvia, Lithuania, Luxembourg, Malta, Netherlands, Poland, Slovakia, Spain, Sweden and the United Kingdom. For each country, a representative sample from the statistical business register covered enterprises with the following characteristics: operating in the business sector, excluding financial services; independent; created at least since 2005 , with at least 10 persons but less than 249 employed in 2005 and 2010. The same questionnaire and methodology were used to collect and treat the results.

\section{Highligths}

In most European countries, the success rate for requests of bank loans is consistently higher for average enterprises than for enterprises experiencing high-growth. Young high-growing enterprises are the less successful in obtaining bank loans due to their lack of credit history and higher perceived risk. The situation is more diverse across countries as concerns equity finance from existing shareholders. Leasing is the form of finance that appears to be equally suitable for enterprises with different growth characteristics, with approval rates relatively similar in most countries.

\section{Sources/online databases}

Eurostat, Structural Business Statistics database, Access to finance, http://epp.eurostat.ec.europa.eu/portal/page/portal/ european_business/data/database

\section{For further readings}

Eurostat/OECD (2007), Eurostat-OECD Manual on Business Demography Statistics, OECD Publishing. 


\section{DETERMINANTS OF ENTREPRENEURSHIP: SELECTED INDICATORS}

Figure 8.4 Success rate in obtaining bank loans, 2010

Percentage

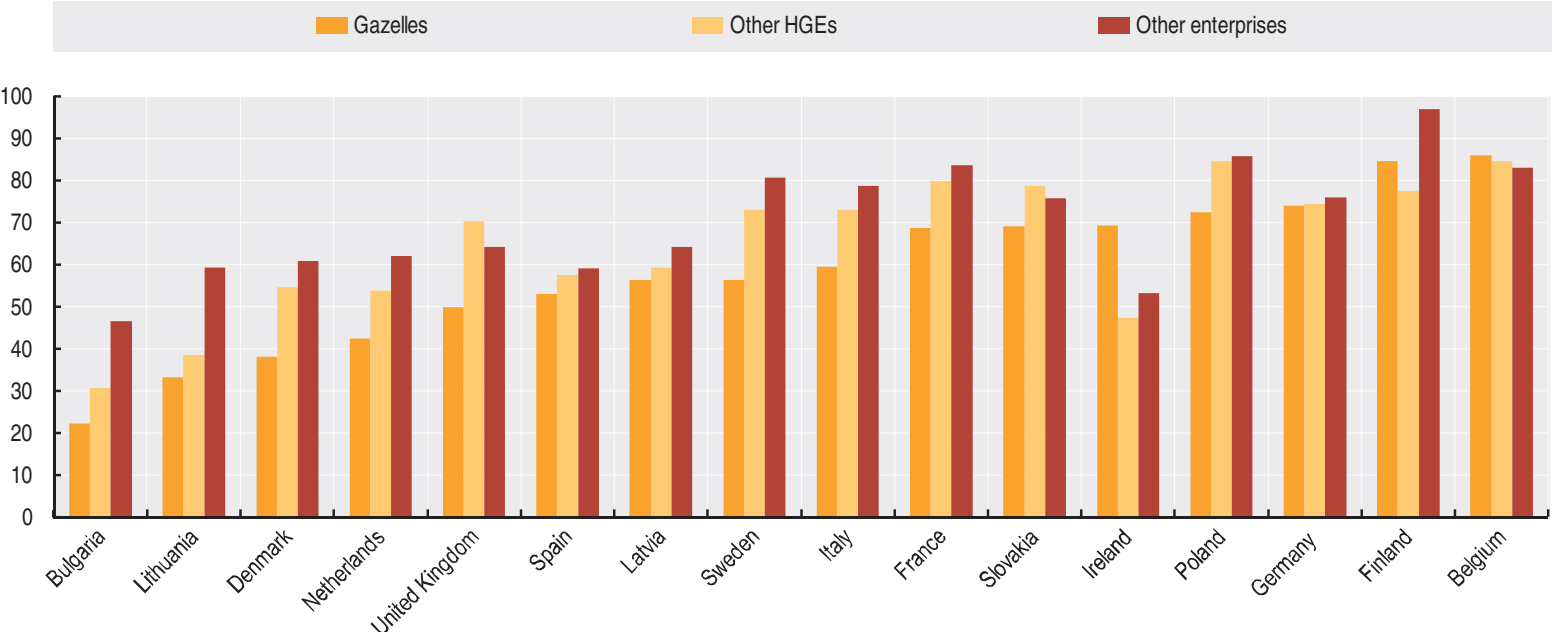

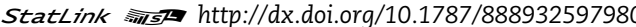
Figure 8.5 Success rate in obtaining equity from existing shareholders, 2010 Percentage

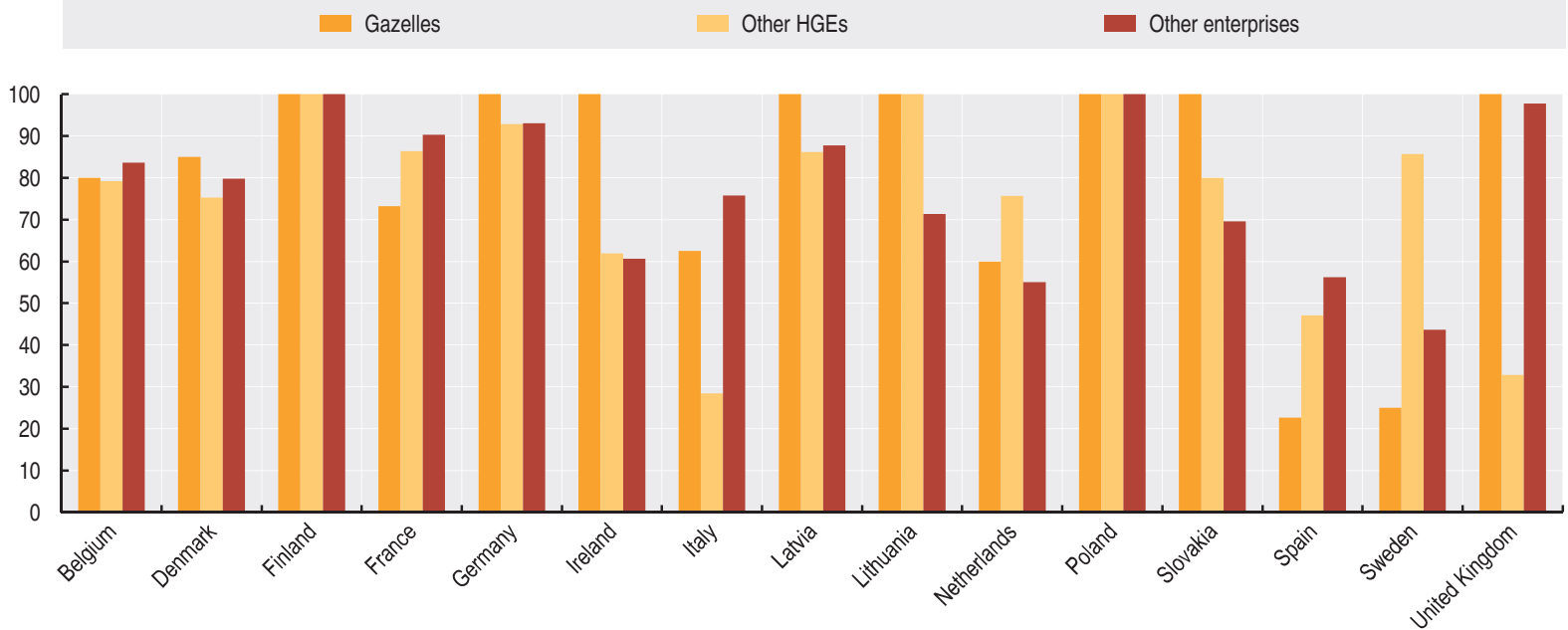

StatLink AाIst $h t t p: / / d x . d o i . o r g / 10.1787 / 888932597999$

Figure 8.6 Success rate in obtaining leasing, 2010 Percentage

Gazelles Other HGEs $\quad$ Other enterprises

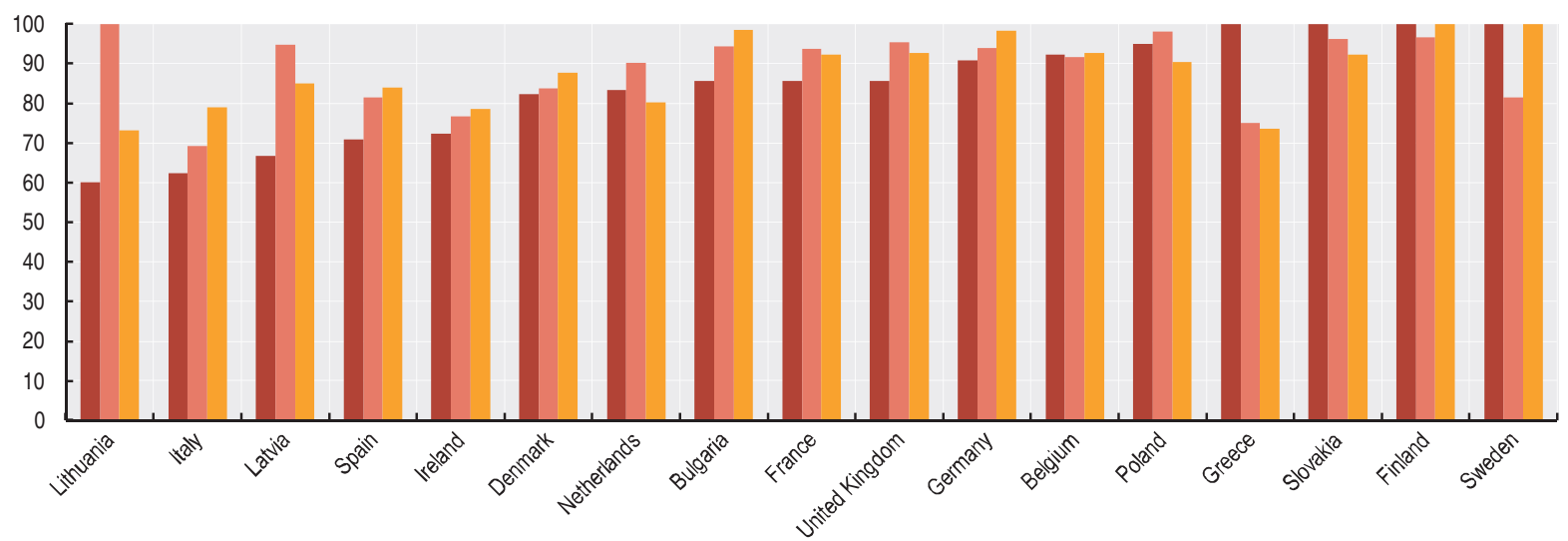

StatLink Aाst http://dx.doi.org/10.1787/888932598018 
The entrepreneurial culture in a country affects the attitude that individuals have towards entrepreneurship, the likelihood of choosing entrepreneurship as a career, the ambitions to success and start again after a failure, or the support provided to family and relatives planning to set up a business. All these aspects play a role, although there is scarce empirical evidence on their relative importance and differences across countries. This section provides examples of indicators that have been developed to measure certain aspects of the entrepreneurial culture related to the image of entrepreneurs and to individuals' perceptions of their own ability as would-be entrepreneurs.

\section{Definition}

The six indicators shown in figures 8.7. and 8.8. respectively describe the following:

- Perceived opportunities: the percentage of 18-64 age group who see good opportunities to start a business in the area where they live.

- Perceived capabilities: the percentage of 18-64 age group who believe to have the required skills and knowledge to start a business.

- Fear of failure rate: the percentage of 18-64 age group with positive perceived opportunities who indicate that fear of failure would prevent them from setting up a business.

- Entrepreneurship as desirable career choice: the percentage of 18-64 age group who agree with the statement that in their country, most people consider starting a business as a desirable career choice.

- High-status successful entrepreneurship: the percentage of 18-64 age group who agree with the statement that in their country, successful entrepreneurs receive high status.

- Media attention for entrepreneurship: the percentage of 18-64 age group who agree with the statement that in their country, they will often see stories in the public media about successful new businesses.

\section{Comparability}

Data on entrepreneurial perceptions and attitudes are produced by the Global Entrepreneurship Monitor (GEM) project. Since 1999, the GEM consortium coordinates an annual adult population survey of at least 2000 individuals aged between 18 and 64 in each country participating in the GEM project. The same survey questionnaire and methodology are used by national teams in participating countries to ensure the harmonisation of data.

The process of data collection varies slightly between national teams. The method by which they identify the 2000 participants depends largely by the percentage coverage of the landline telephone network. Where landline coverage is greater than $85 \%$ of all households, the teams are permitted to use a landline-based survey outreach to generate a suitable list of participants to contact. For those countries where landline telephone coverage is not as wide-spread, face-to-face interview techniques and/or mobile phones are also used.

\section{Highligths}

With the exception of Japan, the perceptions that individuals have of entrepreneurial opportunities and of their own capabilities of starting up a business appear as largely distinct from their attitudes toward entrepreneurship (image of entrepreneurs and entrepreneurship as a career choice). The perceptions of opportunities in particular are likely to be affected by the economic cycle.

\section{Source s/Online databases}

Global Entrepreneurship Monitor data: www.gemconsortium.org/Data.

\section{For further readings}

Bosma N., S. Wennekers and J. E. Amorós (2012), Global Entrepreneurship Monitor Extended Report 2011: Entrepreneurs and Entrepreneurial Employees Across the Globe.

Kelley D. J., N. Bosma and J.E. Amorós (2011), Global Entrepreneurship Monitor Report 2010. 


\section{DETERMINANTS OF ENTREPRENEURSHIP: SELECTED INDICATORS}

Figure 8.7 Entrepreneurial perceptions, 2011 or latest available year

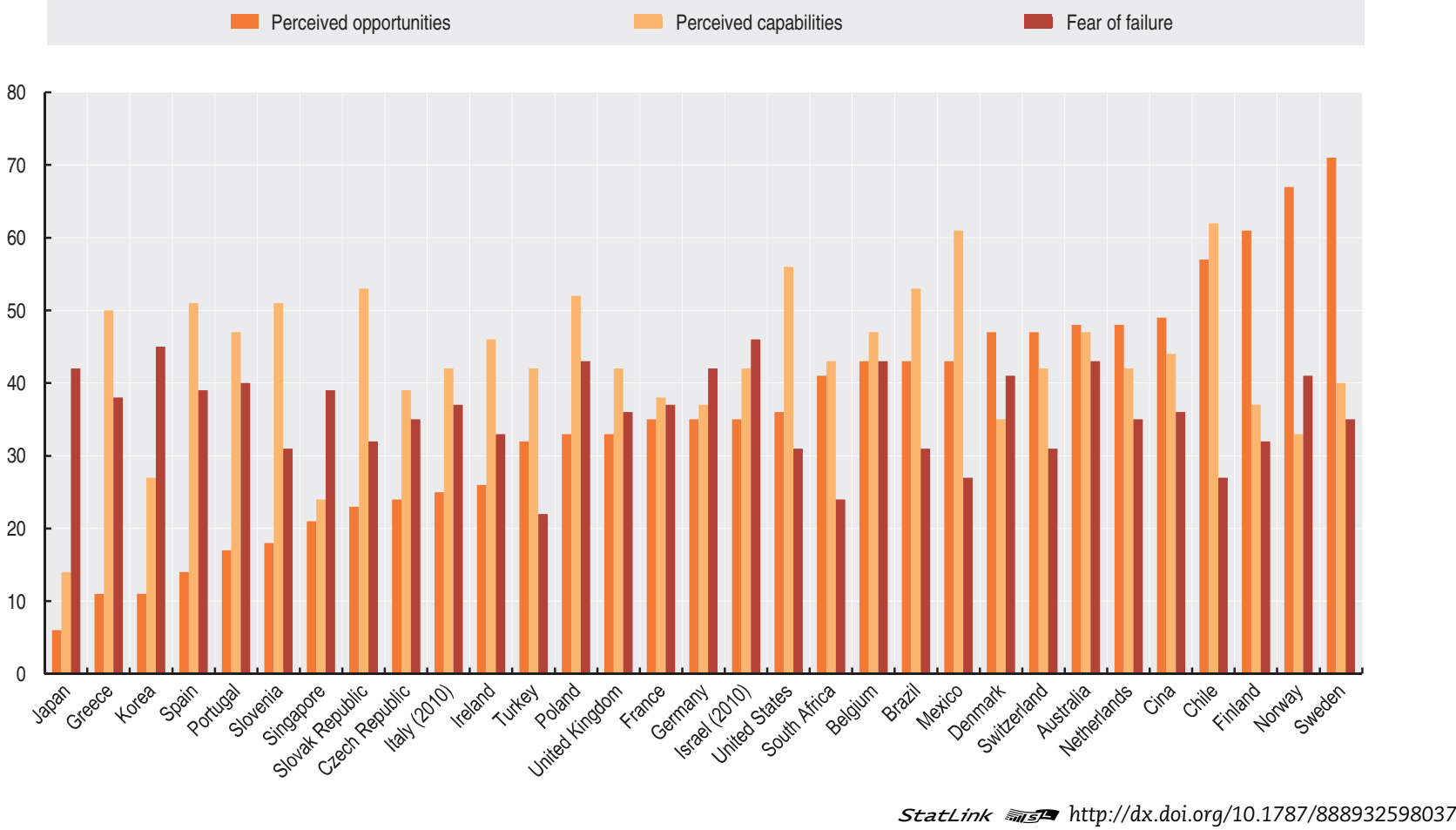

Figure 8.8 Attitudes towards entrepreneurship, 2011 or latest available year

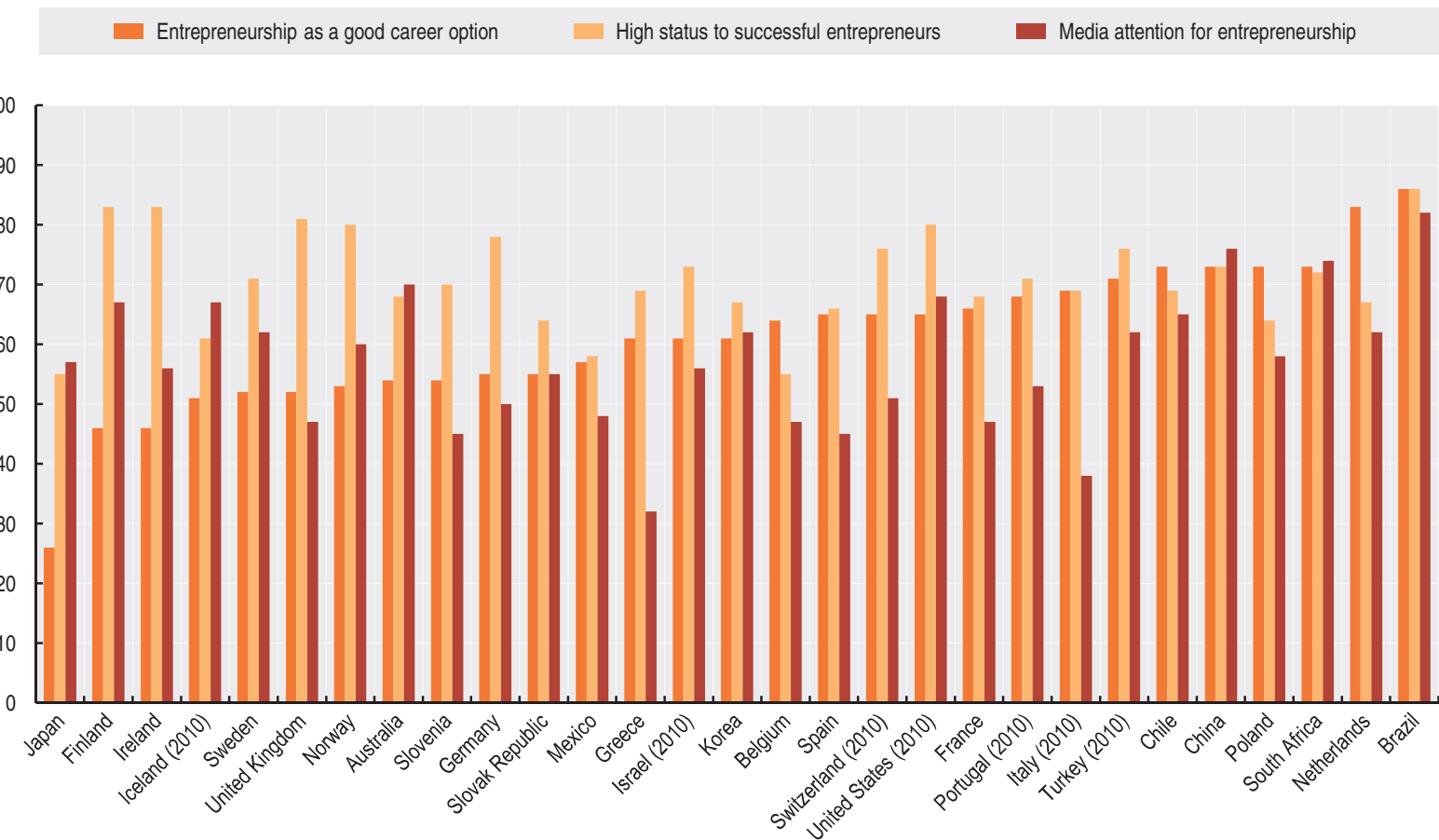

StatLink कीजि http://dx.doi.org/10.1787/888932598056 



\section{ANNEX A \\ List of Indicators of Entrepreneurial Determinants}

This Annex presents a comprehensive list of indicators of entrepreneurial determinants. The list is drawn from the report "Quality Assessment of Entrepreneurship Indicators" (Version 6), prepared by FORA (Denmark). Indicators are classified into the six categories of determinants set by the EIP: 1. Regulatory Framework; 2. Market Conditions; 3. Access to Finance; 4; Creation and Diffusion of Knowledge; 5. Entrepreneurial Capabilities; 6. Entrepreneurial Culture. For each indicator, a short description and the source of data are provided.

While many critical factors affecting entrepreneurship are covered by the indicators presented in the table, the list should not be considered as exhaustive. On the one side, the selection of indicators reflects the current availability of data, meaning that important indicators may be missing, for instance in the determinant area "access to finance", just because no source of international data was found. On the other side, research on entrepreneurship is still young, especially on topics such as the relationship between culture and entrepreneurship, with the result that appropriate indicators are yet to be identified.

Table A.1 Indicators of entrepreneurial determinants and data sources

\begin{tabular}{|c|c|c|}
\hline Category of determinants & Definition & Data sources \\
\hline \multicolumn{3}{|c|}{ 1. REGULATORY FRAMEWORK } \\
\hline \multicolumn{3}{|c|}{ Administrative burdens (entry and growth) } \\
\hline Burden of Government Regulation & $\begin{array}{l}\text { Survey responses to the question: Complying with administrative requirements } \\
\text { (permits, regulations, reporting) issued by the government in your country is } \\
(1=\text { burdensome, } 7=\text { not burdensome). }\end{array}$ & $\begin{array}{l}\text { World Economic Forum } \\
\text { Global Competitiveness Report }\end{array}$ \\
\hline Costs Required for Starting a Business & $\begin{array}{l}\text { The official cost of each procedure in percentage of Gross National Income (GNI) per } \\
\text { capita based on formal legislation and standard assumptions about business and } \\
\text { procedure. }\end{array}$ & World Bank, Doing Business \\
\hline $\begin{array}{l}\text { Minimum Capital Required for Starting } \\
\text { a Business }\end{array}$ & $\begin{array}{l}\text { The paid-in minimum of capital requirement that the entrepreneur needs to deposit in a } \\
\text { bank before registration of the business starts. }\end{array}$ & World Bank, Doing Business \\
\hline $\begin{array}{l}\text { Number of Days for Starting a } \\
\text { Business }\end{array}$ & The average time spent during each enterprise start-up procedure. & World Bank, Doing Business \\
\hline $\begin{array}{l}\text { Number of Procedures for Starting a } \\
\text { Business }\end{array}$ & $\begin{array}{l}\text { All generic procedures that are officially required for an entrepreneur to start an industrial } \\
\text { or commercial business. }\end{array}$ & World Bank, Doing Business \\
\hline $\begin{array}{l}\text { Procedures Time and Costs to Build a } \\
\text { Warehouse }\end{array}$ & $\begin{array}{l}\text { Corresponds to an average of three measurements: 1) Average time spent during each } \\
\text { procedure, 2) Official cost of each procedure and 3) Number of procedures to build a } \\
\text { warehouse. }\end{array}$ & World Bank, Doing Business \\
\hline Registering Property & $\begin{array}{l}\text { Corresponds to an average of three measurements: 1) Number of procedures legally } \\
\text { required to register property, 2) Time spent in completing the procedures and } \\
\text { 3) Registering property costs. }\end{array}$ & World Bank, Doing Business \\
\hline $\begin{array}{l}\text { Time it Takes to Prepare, File and Pay } \\
\text { Corporate Income Tax, VAT and Social } \\
\text { Contributions }\end{array}$ & Time is measured in hours per year. & World Bank, Doing Business \\
\hline
\end{tabular}


Table A.1 Indicators of entrepreneurial determinants and data sources (cont.)

\begin{tabular}{|c|c|c|}
\hline Category of determinants & Definition & Data sources \\
\hline \multicolumn{3}{|l|}{ Bankruptcy Regulations } \\
\hline Actual Cost to Close a Business & The cost is measured in per cent of estate, based on a standard business closure. & World Bank, Doing Business \\
\hline Actual Time to Close a Business & $\begin{array}{l}\text { Time is recorded in calendar years. The indicator is based on a standard business } \\
\text { closure. }\end{array}$ & World Bank, Doing Business \\
\hline Bankruptcy Recovery Rate & $\begin{array}{l}\text { The recovery rate estimates how many cents on the dollar claimants - creditors, tax } \\
\text { authorities and employees - recover from an insolvent firm. }\end{array}$ & World Bank, Doing Business \\
\hline \multicolumn{3}{|c|}{ Product and Labour Market Regulations } \\
\hline Difficulty of Firing & $\begin{array}{l}\text { The index measures whether laws or other regulations have implications for the } \\
\text { difficulties of firing a standard worker in a standard company, based on fact-based (yes/ } \\
\text { no) questions, remodelled into a 0-100 index. }\end{array}$ & World Bank, Doing Business \\
\hline Difficulty of Hiring & $\begin{array}{l}\text { The index measures whether laws or other regulations have implications for the } \\
\text { difficulties of hiring a standard worker in a standard company, based on fact-based (yes/ } \\
\text { no) questions, remodelled into a 0-100 index. }\end{array}$ & World Bank, Doing Business \\
\hline Ease of Hiring Foreign Labour & $\begin{array}{l}\text { Survey responses to the question: Labour regulation in your country ( } 1=\text { prevents your } \\
\text { company from employing foreign labour, } 7=\text { does not prevent your company from } \\
\text { employing foreign labour). }\end{array}$ & $\begin{array}{l}\text { World Economic Forum, Global } \\
\text { Competitiveness Report }\end{array}$ \\
\hline Extent of Incentive Compensation & $\begin{array}{l}\text { Survey responses to the question: Cash compensation of management ( } 1 \text { = is based } \\
\text { exclusively on salary, } 7 \text { = includes bonuses and stock options, representing Reporta } \\
\text { significant portion of overall compensation). }\end{array}$ & $\begin{array}{l}\text { World Economic Forum, Global } \\
\text { Competitiveness }\end{array}$ \\
\hline Rigidity of Hours Index & $\begin{array}{l}\text { The indicator is an index with five components: } i \text { ) whether night work is restricted; } \\
\text { ii) whether weekend work is allowed; iii) whether the work week consists of five and a half } \\
\text { days or more; iv) whether the workday can extend to } 12 \text { hours or more (including } \\
\text { overtime); and v) whether the annual paid vacation days are } 21 \text { days or less. }\end{array}$ & World Bank, Doing Business \\
\hline \multicolumn{3}{|c|}{ Product and Labour Market Regulations } \\
\hline $\begin{array}{l}\text { Enforcing Contracts - Cost in \% of } \\
\text { claim }\end{array}$ & $\begin{array}{l}\text { Cost is recorded as a percentage of the claim, assumed to be equivalent to } 200 \% \text { of } \\
\text { income per capita. No bribes are recorded. Three types of costs are recorded: court } \\
\text { costs, enforcement costs and average attorney fees. }\end{array}$ & World Bank, Doing Business \\
\hline $\begin{array}{l}\text { Enforcing Contracts - Number of } \\
\text { Procedures }\end{array}$ & $\begin{array}{l}\text { A procedure is defined as any interaction between the parties, or between them and the } \\
\text { judge or court officer. This includes steps to file the case, steps for trial and judgment and } \\
\text { steps necessary to enforce the judgment. }\end{array}$ & World Bank, Doing Business \\
\hline Enforcing Contracts - Time & $\begin{array}{l}\text { Time is recorded in calendar days, counted from the moment the plaintiff files the lawsuit } \\
\text { in court until payment. This includes both the days when actions take place and the } \\
\text { waiting periods between }\end{array}$ & World Bank, Doing Business \\
\hline \multicolumn{3}{|c|}{ Product and Labour Market Regulations } \\
\hline $\begin{array}{l}\text { Public Expenditure on Unemployment } \\
\text { Support }\end{array}$ & $\begin{array}{l}\text { Public expenditure on unemployment per unemployed in USD, current PPPS. } \\
\text { Public expenditure includes both partly, full public pay and any other program } \\
\text { expenditures the public has. }\end{array}$ & $\begin{array}{l}\text { OECD, Public expenditure and participant } \\
\text { stocks on Labour Market Policy (LMP) }\end{array}$ \\
\hline Public Health Care Coverage & $\begin{array}{l}\text { The share of the population eligible for a defined set of health care goods and services } \\
\text { under public programmes }\end{array}$ & OECD Health data \\
\hline \multicolumn{3}{|l|}{ Income taxes; Wealth/Bequest Taxes } \\
\hline $\begin{array}{l}\text { Average Income Tax plus Social } \\
\text { Contributions }\end{array}$ & $\begin{array}{l}\text { The average rate of taxation in percentage of the gross wage. The indicator is based on a } \\
\text { standard case: single (without children) with high income. }\end{array}$ & OECD Revenue Statistics \\
\hline $\begin{array}{l}\text { Highest Marginal Income Tax plus } \\
\text { Social Contributions }\end{array}$ & $\begin{array}{l}\text { The highest rate of taxation in percentage of the gross wage. The indicator is based on a } \\
\text { standard case: single (without children) with high income. }\end{array}$ & OECD Revenue Statistics \\
\hline Revenue from Bequest Tax & The revenue from bequest tax as a per cent of GDP on a 3 year moving average. & OECD Revenue Statistics \\
\hline Revenue from Net Wealth Tax & The revenue from net wealth tax as a per cent of GDP on a 3 year moving average. & OECD Revenue Statistics \\
\hline \multicolumn{3}{|l|}{ Business and Capital Taxes } \\
\hline SME Tax Rates & & OECD Revenue Statistics \\
\hline Taxation of Corporate Income Revenue & $\begin{array}{l}\text { The revenue from corporate income tax as percentage of GDP on a three year moving } \\
\text { average. }\end{array}$ & OECD Revenue Statistics \\
\hline $\begin{array}{l}\text { Taxation of Dividends - Top Marginal } \\
\text { Tax Rate }\end{array}$ & & OECD Tax Database \\
\hline Taxation of Stock Options & The average tax wedge for purchased and newly listed stocks. Average incomes are used. & $\begin{array}{l}\text { OECD, The Taxation of Employee Stock } \\
\text { Options - Tax Policy Study No. } 11\end{array}$ \\
\hline \multicolumn{3}{|l|}{ Patent System; Standards } \\
\hline Intellectual Property Rights & $\begin{array}{l}\text { Survey responses to the question: intellectual property protection in the world ( } 1 \text { = is } \\
\text { weak or nonexistent, } 7 \text { = is equal to the world's most stringent). }\end{array}$ & $\begin{array}{l}\text { World Economic Forum, Global } \\
\text { Competitiveness Report }\end{array}$ \\
\hline Property Rights & $\begin{array}{l}\text { Survey responses to the question: property rights, including over financial assets ( } 1 \\
=\text { are World Economic Forum, poorly defined and not protected by law, } 7 \text { = are } \\
\text { clearly defined and well protected by law). }\end{array}$ & Global Competitiveness Report \\
\hline
\end{tabular}


Table A.1 Indicators of entrepreneurial determinants and data sources (cont.)

\begin{tabular}{|c|c|c|}
\hline Category of determinants & Definition & Data sources \\
\hline \multicolumn{3}{|c|}{ 2. MARKET CONDITIONS } \\
\hline \multicolumn{3}{|l|}{ Access to Foreign Markets } \\
\hline Export Burdens & $\begin{array}{l}\text { An average of three measurements: 1) Number of all documents required to export } \\
\text { goods, 2) Number of signatures required to export goods, 3) Time necessary to } \\
\text { comply with all procedures required to export goods. }\end{array}$ & World Bank, Doing Business \\
\hline Import Burdens & $\begin{array}{l}\text { An average of three measurements: 1) Number of all documents required to import } \\
\text { goods, 2) Number of signatures required to import goods, 3) Time necessary to } \\
\text { comply with all procedures required to import goods. }\end{array}$ & World Bank, Doing Business \\
\hline \multicolumn{3}{|l|}{ Degree of Public Involvement } \\
\hline $\begin{array}{l}\text { Government Enterprises and } \\
\text { Investment }\end{array}$ & $\begin{array}{l}\text { Data is composed of the number, composition, and share of output supplied by } \\
\text { State-Operated Enterprises (SOEs) and government investment as a share of total } \\
\text { investment. }\end{array}$ & $\begin{array}{l}\text { IMF, World Bank, UN National Accounts and } \\
\text { World Economic Forum }\end{array}$ \\
\hline Licensing Restrictions & $\begin{array}{l}\text { Zero-to- } 10 \text { ratings are constructed for } 1 \text { ) the time cost (measured in number of } \\
\text { calendar days required to obtain a license) and } 2 \text { ) the monetary cost of obtaining the } \\
\text { license (measured as a share of per-capita income). These two ratings are then } \\
\text { averaged to arrive at the final rating. }\end{array}$ & World Bank \\
\hline Ownership of Banks & $\begin{array}{l}\text { Data on the percentage of bank deposits held in privately owned banks is used to } \\
\text { construct rating intervals of public ownership in the financial sector. }\end{array}$ & World Bank \\
\hline Price Controls & $\begin{array}{l}\text { The indicator measures the extent to which prices are determined by the market or } \\
\text { by government involvement. }\end{array}$ & IMD World Competitiveness Yearbook \\
\hline \multicolumn{3}{|l|}{ Private Demand } \\
\hline Buyer Sophistication & $\begin{array}{l}\text { Survey responses to: purchasing decisions are }(1=\text { based solely on the lowest price, } \\
7=\text { based on a sophisticated analysis of performance }) \text {. }\end{array}$ & $\begin{array}{l}\text { World Economic Forum, Global } \\
\text { Competitiveness Report }\end{array}$ \\
\hline \multicolumn{3}{|c|}{ 3. ACCESS TO FINANCE } \\
\hline \multicolumn{3}{|l|}{ Access to Debt Financing } \\
\hline Country Credit Rating & $\begin{array}{l}\text { The indicator is based on an assessment by the Institutional Investor Magazine } \\
\text { Ranking. }\end{array}$ & IMD World Competitiveness Yearbook \\
\hline Domestic Credit to private sector & $\begin{array}{l}\text { The indicator refers to financial resources provided to the private sector - such as } \\
\text { through loans, purchases of non-equity securities, and trade credits and other } \\
\text { accounts receivable - that establish a claim for repayment. }\end{array}$ & $\begin{array}{l}\text { Published in World Development Indicators, } \\
\text { World Bank. Data are from IMF's } \\
\text { International Financial Statistics }\end{array}$ \\
\hline Ease of Access to Loans & $\begin{array}{l}\text { Survey responses to: how easy it is to obtain a bank loan in your country with only a } \\
\text { good business plan and no collateral ( } 1=\text { impossible, } 7=\text { easy). }\end{array}$ & $\begin{array}{l}\text { World Economic Forum, Global } \\
\text { Competitiveness Report }\end{array}$ \\
\hline Interest Rate Spread & $\begin{array}{l}\text { The lending rate minus deposit rate based on an average of annual rates for each } \\
\text { country. }\end{array}$ & IMF, International Financial Statistics \\
\hline Legal Rights Index & $\begin{array}{l}\text { The degree to which collateral and bankruptcy laws facilitate lending. Higher scores } \\
\text { indicating that collateral and bankruptcy laws are better designed to expand access } \\
\text { to credit. }\end{array}$ & World Bank, Doing Business \\
\hline $\begin{array}{l}\text { Share of SME loans in business } \\
\text { loans }\end{array}$ & & $\begin{array}{l}\text { OECD, Financing SMEs and } \\
\text { Entrepreneurship: An OECD Scoreboard }\end{array}$ \\
\hline SME Ioan guarantees & & $\begin{array}{l}\text { OECD, Financing SMEs and } \\
\text { Entrepreneurship: An OECD Scoreboard }\end{array}$ \\
\hline SME interest rates & & $\begin{array}{l}\text { OECD, Financing SMEs and } \\
\text { Entrepreneurship: An OECD Scoreboard }\end{array}$ \\
\hline \multicolumn{3}{|l|}{ Access to Venture Capital } \\
\hline Venture Capital Availability & $\begin{array}{l}\text { Survey responses to: entrepreneurs with innovative but risky projects can generally } \\
\text { find venture capital in your country }(1=\text { not true, } 7=\text { true). }\end{array}$ & $\begin{array}{l}\text { World Economic Forum, Global } \\
\text { Competitiveness Report }\end{array}$ \\
\hline Venture Capital - Early Stage & $\begin{array}{l}\text { The level of investment performed by Venture Capital firms towards young businesses in } \\
\text { seed and start-up phases. }\end{array}$ & $\begin{array}{l}\text { OECD Entrepreneurship Indicators } \\
\text { Programme based on the following sources: } \\
\text { ABS: Australian Bureau of Statistics } \\
\text { EVCA: European Private Equity and venture } \\
\text { Capital Association } \\
\text { VEC: Venture Enterprise Center } \\
\text { KVCA: Korean Venture Capital Association } \\
\text { NZVCA: New Zealand Venture Capital } \\
\text { Association }\end{array}$ \\
\hline
\end{tabular}


Table A.1 Indicators of entrepreneurial determinants and data sources (cont.)

\begin{tabular}{|c|c|c|}
\hline Category of determinants & Definition & Data sources \\
\hline Venture Capital - Expansion Stage & $\begin{array}{l}\text { The level of investment performed by the VC sector for young firms in an expansion } \\
\text { phase (the phase following the seed and start-up phase). }\end{array}$ & $\begin{array}{l}\text { OECD Entrepreneurship Indicators } \\
\text { Programme based on the following sources } \\
\text { ABS: Australian Bureau of Statistics } \\
\text { EVCA: European Private Equity and venture } \\
\text { Capital Association } \\
\text { VEC: Venture Enterprise Center } \\
\text { KVCA: Korean Venture Capital Association } \\
\text { NZVCA: New Zealand Venture Capital } \\
\text { Association }\end{array}$ \\
\hline \multicolumn{3}{|l|}{ Stock Markets } \\
\hline Capitalisation of Primary Stock Market & $\begin{array}{l}\text { The capitalisation of the primary stock market (the value of the issued shares on the } \\
\text { market) relative to GDP. }\end{array}$ & World Federation of Exchange \\
\hline $\begin{array}{l}\text { Capitalisation of Secondary Stock } \\
\text { Market }\end{array}$ & $\begin{array}{l}\text { An assessment of the efficiency of stock markets providing finance to companies. } \\
\text { Ranking goes from } 1 \text { (worst) to } 10 \text { (best). }\end{array}$ & IMD World Competitiveness Yearbook \\
\hline Investor Protection & $\begin{array}{l}\text { The main indicators include: transparency of transactions (Extent of Disclosure } \\
\text { Index), liability for self-dealing (Extent of Director Liability Index), shareholders' ability to } \\
\text { sue officers and directors for misconduct (Ease of Shareholder Suit Index), strength of } \\
\text { Investor Protection Index (the average of the three index). }\end{array}$ & World Bank, Doing Business \\
\hline $\begin{array}{l}\text { Market Capitalisation of Newly Listed } \\
\text { Companies }\end{array}$ & $\begin{array}{l}\text { The market capitalization (total number of new shares issued multiplied by their value on } \\
\text { the first day of quotation) of newly listed domestic shares relative to GDP. }\end{array}$ & World Federation of Exchange \\
\hline Turnover in Primary Stock Market & The total shares traded on the stock market exchange in percentage of GDP. & $\begin{array}{l}\text { World Bank and Standard and Poor's } \\
\text { Emerging Market Database }\end{array}$ \\
\hline \multicolumn{3}{|c|}{ 4. CREATION AND DIFFUSION OF KNOWLEDGE } \\
\hline \multicolumn{3}{|l|}{ R\&D Activity } \\
\hline Business Expenditure on R\&D - BERD & & OECD Science and Technology Statistics \\
\hline $\begin{array}{l}\text { Government Expenditure on R\&D - } \\
\text { GERD }\end{array}$ & & OECD Science and Technology Statistics \\
\hline $\begin{array}{l}\text { Higher Education Expenditure on R\&D } \\
\text {-HERD }\end{array}$ & & OECD Science and Technology Statistics \\
\hline $\begin{array}{l}\text { International Co-operation Between } \\
\text { Patent Applications at PCT }\end{array}$ & $\begin{array}{l}\text { The indicator measures international co-operation between patent applications under the } \\
\text { Patent Cooperation Treaty (PCT). The measure is calculated as a percentage of total } \\
\text { patents (by application date). }\end{array}$ & OECD Science and Technology Statistics \\
\hline $\begin{array}{l}\text { Patents Awarded Based on Inventors } \\
\text { Residence }\end{array}$ & $\begin{array}{l}\text { Number of patents awarded to inventors based on their residence. The indicator is a sum } \\
\text { of patents awarded by the European Patent Office (EPO) and US Patent and Trademark } \\
\text { Office (USPTO). }\end{array}$ & OECD Science and Technology Statistics \\
\hline Private Funding of R\&D Activity & $\begin{array}{l}\text { Total private founded R\&D investments, independent of where the founding is spent. The } \\
\text { indicator is measured as a percentage of GDP. }\end{array}$ & OECD Science and Technology Statistics \\
\hline Public Funding of R\&D Activity & Total public funding of R\&D - as a percentage of GDP. & OECD Science and Technology Statistics \\
\hline \multicolumn{3}{|c|}{ Transfer of non-commercial Knowledge } \\
\hline Research in Higher Education Sector & $\begin{array}{l}\text { R\&D expenditure performed at higher education and funded by business, measured } \\
\text { Financed by Business as a percentage of total research expenditure. }\end{array}$ & OECD Science and Technology Statistics \\
\hline $\begin{array}{l}\text { Share of Patents Owned by } \\
\text { Universities }\end{array}$ & $\begin{array}{l}\text { The percentage of patents owned by universities. Only countries/economies with more } \\
\text { than } 300 \text { patents are included. }\end{array}$ & OECD Patent Database \\
\hline $\begin{array}{l}\text { Universities or other Public Research } \\
\text { Organizations as Source of Innovation }\end{array}$ & $\begin{array}{l}\text { The share of innovative enterprises that states universities or other PROs as an important } \\
\text { source of innovation. }\end{array}$ & $\begin{array}{l}\text { Eurostat, European Community Innovation } \\
\text { Survey (CIS) }\end{array}$ \\
\hline $\begin{array}{l}\text { University/Industry Research } \\
\text { Collaboration }\end{array}$ & $\begin{array}{l}\text { Survey responses to: the level of collaboration between business and universities in } \\
\text { R\&D. ( } 1 \text { for minimal or nonexistent to } 7 \text { for intensive and ongoing). }\end{array}$ & $\begin{array}{l}\text { World Economic Forum, Global } \\
\text { Competitiveness Report }\end{array}$ \\
\hline \multicolumn{3}{|l|}{ Co-operation Among Firms } \\
\hline $\begin{array}{l}\text { SMEs Stating Co-operation as the } \\
\text { Source of Innovation }\end{array}$ & $\begin{array}{l}\text { The share of innovative small and medium sized enterprises (SMEs) stating any type of } \\
\text { co-operation as the source of innovation. }\end{array}$ & $\begin{array}{l}\text { Eurostat, European Community Innovation } \\
\text { Survey (CIS) }\end{array}$ \\
\hline \multicolumn{3}{|l|}{ Technology availability and take-up } \\
\hline Turnover from e-Commerce & $\begin{array}{l}\text { Total internet sales over the last calendar year, excluding VAT, as a percentageof total } \\
\text { turnover. }\end{array}$ & Eurostat, Information Society Statistics \\
\hline Enterprises Using e-Government & $\begin{array}{l}\text { The share of enterprises using any eGovernment services. The measure is based on all } \\
\text { firms with } 10 \text { employees or more, excluding the financial sector. }\end{array}$ & Information Society Statistics \\
\hline ICT expenditure & Expenditure for ICT equipment, software and services as a percentage of GDP. & $\begin{array}{l}\text { European Information Technology } \\
\text { Observatory (EITO) }\end{array}$ \\
\hline ICT expenditure in Communications & $\begin{array}{l}\text { Expenditure for telecommunications equipment and carrier services as a percentage of } \\
\text { GDP. }\end{array}$ & $\begin{array}{l}\text { European Information Technology } \\
\text { Observatory (EITO) }\end{array}$ \\
\hline
\end{tabular}


Table A.1 Indicators of entrepreneurial determinants and data sources (cont.)

\begin{tabular}{|c|c|c|}
\hline Category of determinants & Definition & Data sources \\
\hline \multicolumn{3}{|c|}{ 5. ENTREPRENEURIAL CAPABILITIES } \\
\hline \multicolumn{3}{|c|}{ Business and Entrepreneurship education (skills) } \\
\hline $\begin{array}{l}\text { International Students in Tertiary } \\
\text { Education }\end{array}$ & The share of international students in total tertiary enrolments. & OECD Education at a Glance \\
\hline Population with Tertiary Education & $\begin{array}{l}\text { The share of persons between 25-34 of age with tertiary-type B education or tertiary-type } \\
\text { A education and advanced research programmes }\end{array}$ & OECD Education at a Glance \\
\hline Quality of Management Schools & $\begin{array}{l}\text { Survey responses to: the quality of management schools across Countries is (limited or } \\
\text { of poor quality for } 1 \text {, to amongst the best in the World for } 7 \text { ). }\end{array}$ & $\begin{array}{l}\text { World Economic Forum, Global } \\
\text { Competitiveness Report }\end{array}$ \\
\hline $\begin{array}{l}\text { Received Training in Starting a } \\
\text { Business During School }\end{array}$ & $\begin{array}{l}\text { The percentage of the population aged 18-64 that received training - voluntary or } \\
\text { compulsory - in starting a business during school. }\end{array}$ & $\begin{array}{l}\text { Global Entrepreneurship Monitor (GEM) } \\
2008 \text { Executive Report }\end{array}$ \\
\hline $\begin{array}{l}\text { Received Training in Starting a } \\
\text { Business After School }\end{array}$ & $\begin{array}{l}\text { The percentage of the population aged 18-64 that received training - voluntary or } \\
\text { compulsory - in starting a business after school. }\end{array}$ & $\begin{array}{l}\text { Global Entrepreneurship Monitor (GEM) } \\
2008 \text { Executive Report }\end{array}$ \\
\hline \multicolumn{3}{|l|}{ Immigration } \\
\hline Inflows of foreign labour & Inflows of foreign workers as a percentage of the total labor force. & OECD International Migration Outlook \\
\hline Migrants with Tertiary Education & The share of highly skilled migrants as a percentage of total migrants. & $\begin{array}{l}\text { OECD, A profile of immigrant populations in } \\
\text { the } 21 \text { st century. Database on immigrants in } \\
\text { OECD countries (DIOC) }\end{array}$ \\
\hline Self-employment by Place of Birth & $\begin{array}{l}\text { The share of self-employment by foreign-born persons. Self-employment is measured as } \\
\text { a percentage of total employment. }\end{array}$ & OECD International Migration Outlook \\
\hline Stocks of foreign labour & The stock of foreign workers as a percentage of the total labour force. & OECD International Migration Outlook \\
\hline \multicolumn{3}{|c|}{ 6. ENTREPRENEURSHIP CULTURE } \\
\hline $\begin{array}{l}\text { Desirability of Becoming Self- } \\
\text { Employed }\end{array}$ & $\begin{array}{l}\text { Survey responses to: desire to become self-employed within the next } 5 \text { years. This } \\
\text { question was asked only to non-self-employed individuals. }\end{array}$ & $\begin{array}{l}\text { European Commission, } \\
\text { Flash Eurobarometer }\end{array}$ \\
\hline Entrepreneurial Intention & $\begin{array}{l}\text { The percentage of 18-64 population (individuals involved in any stage of entrepreneurial } \\
\text { activity excluded) who intend to start a business within three years. }\end{array}$ & $\begin{array}{l}\text { Global Entrepreneurship Monitor (GEM) } \\
2009 \text { Executive Report }\end{array}$ \\
\hline Entrepreneurial Motivation & $\begin{array}{l}\text { The percentage of early stage entrepreneurs who were motivated by either a) a desire for } \\
\text { independence or } b \text { ) a desire to increase their income. }\end{array}$ & $\begin{array}{l}\text { Global Entrepreneurship Monitor (GEM) } \\
2007 \text { Executive Report }\end{array}$ \\
\hline Entrepreneurship among Managers & $\begin{array}{l}\text { How senior executives rank the level of entrepreneurship of business managers in the } \\
\text { given country from a scale of } 0 \text { to } 10 \text {. }\end{array}$ & IMD World Competitiveness Yearbook. \\
\hline Entrepreneurs are Job Creators & Survey responses. & $\begin{array}{l}\text { European Commission, } \\
\text { Flash Eurobarometer }\end{array}$ \\
\hline $\begin{array}{l}\text { Entrepreneurs Exploit other People's } \\
\text { Work }\end{array}$ & Survey responses. & $\begin{array}{l}\text { European Commission, } \\
\text { Flash Eurobarometer }\end{array}$ \\
\hline $\begin{array}{l}\text { Entrepreneurs is Basis for Wealth } \\
\text { Creation }\end{array}$ & Survey responses. & $\begin{array}{l}\text { European Commission, } \\
\text { Flash Eurobarometer }\end{array}$ \\
\hline $\begin{array}{l}\text { Entrepreneurs think only about their } \\
\text { Own Wallets }\end{array}$ & Survey responses. & $\begin{array}{l}\text { European Commission, } \\
\text { Flash Eurobarometer }\end{array}$ \\
\hline $\begin{array}{l}\text { Fear of Failure would prevent Starting } \\
\text { a Business }\end{array}$ & $\begin{array}{l}\text { The percentage of non-entrepreneurially active adult population aged 18-64 that } \\
\text { sees good opportunities to start a business, where fear of failure would prevent } \\
\text { starting a business }\end{array}$ & $\begin{array}{l}\text { Global Entrepreneurship Monitor (GEM) } \\
2008 \text { Executive Report }\end{array}$ \\
\hline Good Conditions to Start a Business & $\begin{array}{l}\text { The percentage of non-entrepreneurially active adult population aged 18-64 that } \\
\text { sees good opportunities for starting a business in the next } 6 \text { months. }\end{array}$ & $\begin{array}{l}\text { Global Entrepreneurship Monitor (GEM) } \\
2008 \text { Executive Report }\end{array}$ \\
\hline Image of entrepreneurs & $\begin{array}{l}\text { Survey responses to: image of entrepreneurs according to their status in society. } \\
\text { Entrepreneurs are ranked against civil servants and managers. }\end{array}$ & $\begin{array}{l}\text { European Commission, } \\
\text { Flash Eurobarometer }\end{array}$ \\
\hline Risk for Business Failure & Survey responses to: being willing to start a business if a risk exists that it might fail. & $\begin{array}{l}\text { European Commission, } \\
\text { Flash Eurobarometer }\end{array}$ \\
\hline $\begin{array}{l}\text { The Wish to Own one's Own } \\
\text { Business' }\end{array}$ & Survey responses. & $\begin{array}{l}\text { European Commission, } \\
\text { Flash Eurobarometer }\end{array}$ \\
\hline \multicolumn{3}{|l|}{ Entrepreneurship education (mindset) } \\
\hline Self-Employment Preference & $\begin{array}{l}\text { Survey responses to: preferences towards being self employed or being an } \\
\text { employee. }\end{array}$ & $\begin{array}{l}\text { European Commission, } \\
\text { Flash Eurobarometer }\end{array}$ \\
\hline
\end{tabular}




\section{ANNEX B \\ Eurostat's 2010 Survey Questionnaire on Access to Finance (frozen version of 12 March 2010)}

\section{Purpose of this survey}

Access to finance is crucial to business success and an important factor for economic growth in Europe following the economic crisis in 2007. The purpose of this survey is to examine where there may be constraints on the availability of finance, and how those may be changing; the need for finance (loans, equity and other) in the future, for example to promote growth, and the sources from which businesses would wish to obtain this finance.

\section{Coverage}

This questionnaire asks for information in relation to your business in [your home country].

\section{Information required}

This questionnaire is divided into sections

Section A asks for general information about your business

Section B asks for information regarding seeking loan finance

Section $\mathrm{C}$ asks for information regarding seeking equity finance

Section D asks for information regarding other sources of finance

Section E asks for information regarding changes between 2007 and 2010

Section $\mathrm{F}$ asks for information regarding your outlook in the next three years

Section $\mathrm{G}$ provides you with a comments box and asks for contact details

\section{How to complete the questionnaire}

- We are looking for the owner or manager of the business or the group to respond.

- Most of the questions can be completed by placing an $\mathrm{X}$ in the relevant boxes.

Please:

- $\quad$ complete in black ink

- $\quad$ ensure letters and numbers are PRINTED and centred within each box

- leave response boxes blank if the question is not applicable

- do not use commas

- $\quad$ do not cross sevens 7 or $\varnothing$ 


\section{Section A - Introduction}

This section asks for information that aims to identify the independence and ownership situation of your business.

1a. Was this business a subsidiary of another firm in 2007 and/or in 2010 ?

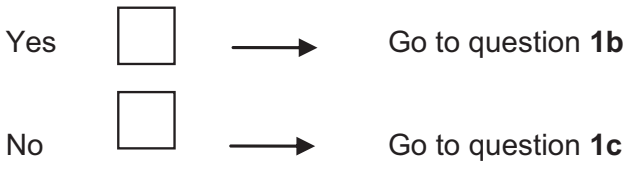

1b. If you are a subsidiary, what is the name of your current parent company?

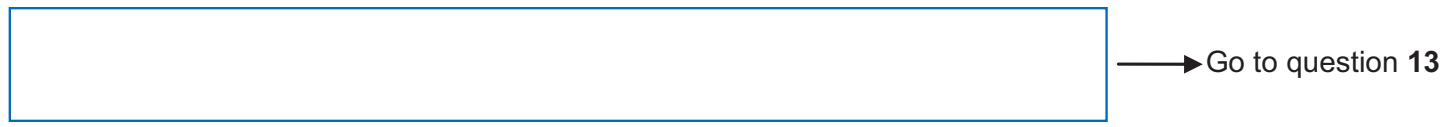

1c. What is this business's total number of employees?

Include employees in subsidiaries within [your home country] or overseas,

if the business is the head of a group

Under 10 employees . . . . . . . . . . . . . .

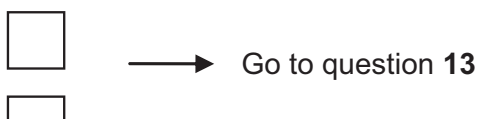

10 or more employees.

$\longrightarrow$ Go to question 1d

1d. What was the ownership situation of the business at the beginning of your financial year 2004, 2007 and 2010?

$$
\begin{array}{rrr}
\text { Please } & X & \text { one box only for each year } \\
2010 & 2007 & 2004
\end{array}
$$

i. Sole proprietorship
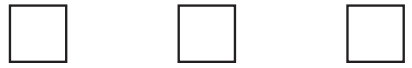

ii. Partnership

iii. Limited liability company, not publicly listed

iv. Limited liability company, publicly listed
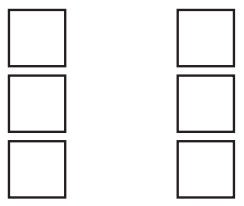

v. Other
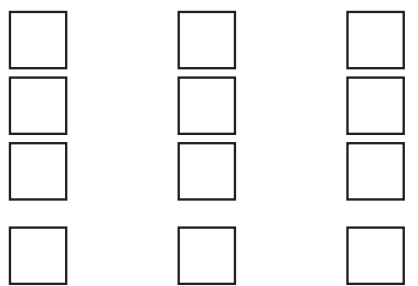

If 'Other', please specify separately for each year in the box below: 


\section{Section B - Seeking Loan Finance}

This section is about your success in obtaining loan finance in 2010 and 2007.

Loan finance refers to debt that you have to pay back.

Exclude bank overdraft/credit lines, preferred debt, leasing subsidized loans or subordinated loans.

\section{2a. In $\mathbf{2 0 1 0}$ did you seek any loan finance?}

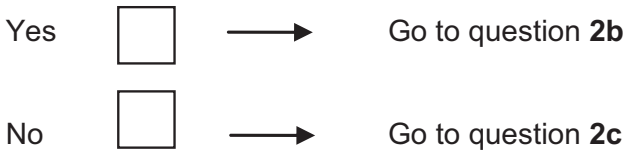

2b. How successful were you in obtaining loan finance from each of the following sources in $\underline{2010}$ ? Partially successful refers to not getting the requested amount or not on the desired terms.

$$
\begin{array}{rll}
\text { Please } & X \text { all that apply } \\
\text { Successful } & \text { Partially } \quad \text { Unsuccessful } \\
& \text { Successful } &
\end{array}
$$

i. The owner(s)/director(s) $\ldots \ldots \ldots \ldots \ldots \ldots \ldots$
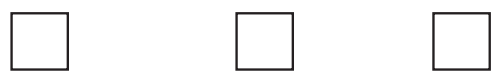

ii. Other employees of your business
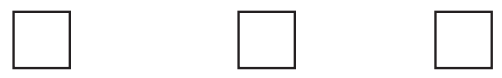

iii. Family, friends or other individuals outside your business
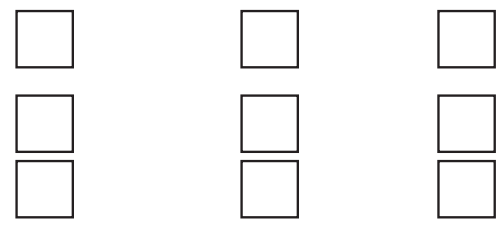

iv. Other businesses $\ldots \ldots \ldots \ldots \ldots \ldots \ldots \ldots \ldots \ldots$

v. Banks

vi. Other loan sources e.g. finance houses and subsidiaries of banks

Please specify the other loan sources

2c. In 2007 did you seek any loan finance?

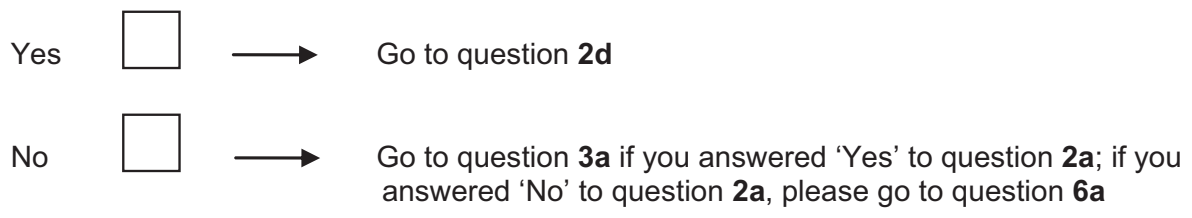


2d. How successful were you in obtaining loan finance from each of the following sources in 2007? Partially successful refers to not getting the requested amount or not on the desired terms.

$\begin{array}{lll} & \text { Please } X \text { all that apply } \\ \text { Successful } & \text { Partially } & \text { Unsuccessful } \\ & \text { Successful } & \end{array}$

i. The owner(s)/director(s) $\ldots \ldots \ldots \ldots \ldots \ldots \ldots \ldots$

ii. Other employees of your business .
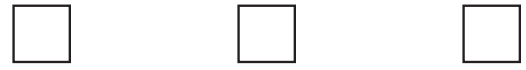

iii. Family, friends or other individuals outside your business

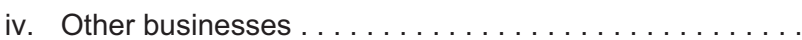

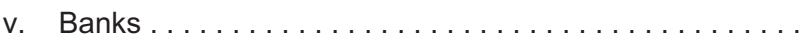
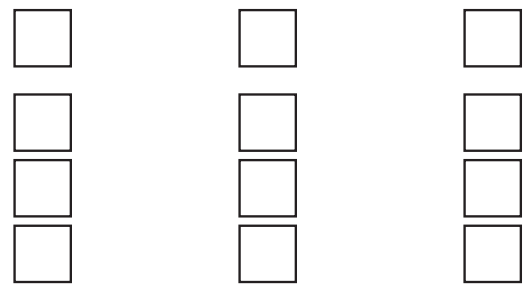

vi. Other loan sources e.g. finance houses and subsidiaries of banks
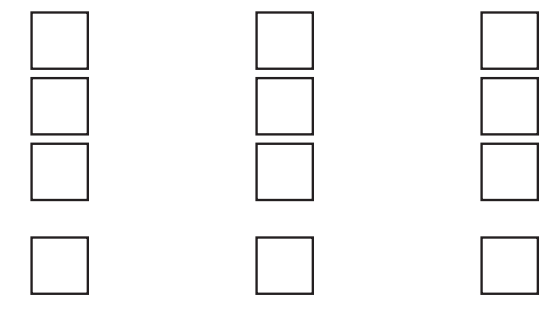

Please specify the other loan sources

3a. If you did obtain any loan finance in $\mathbf{2 0 1 0}$ or $\mathbf{2 0 0 7}$, was there a guarantee? Guarantors refer to individuals or entities that cover the risks of the loan default.

Please $X$ one box only for each year

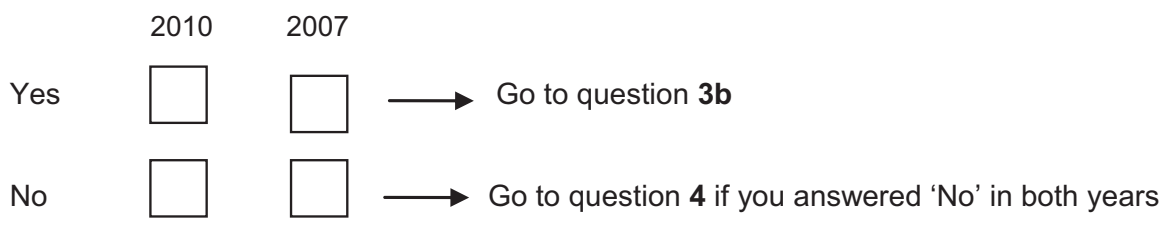

3b. Who guaranteed the loan?

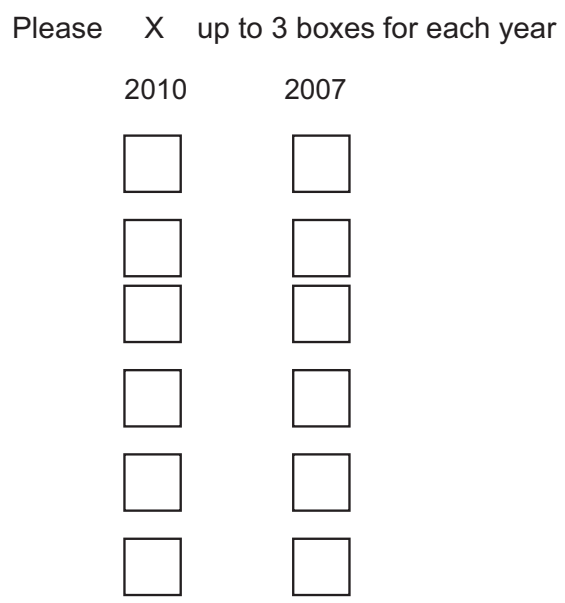


4. If you were partially successful or unsuccessful (see question $2 b$ and $2 d$ ) in obtaining loan finance, during the financial year ending on any date in $\mathbf{2 0 1 0}$ or $\mathbf{2 0 0 7}$, what were the reasons for this?

Please $\quad X$ all boxes that apply for each year

It was the bank's opinion that our business had:

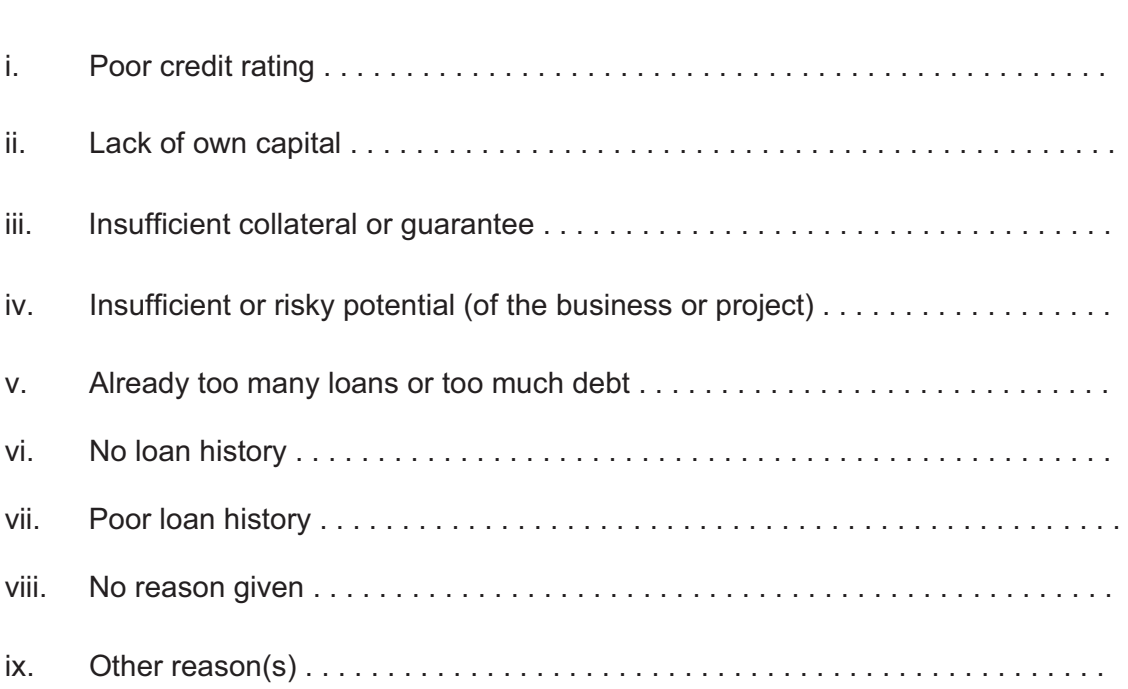

iii.

ease specify separately for 2010 and 2007

Please specify separately for 2010 and 2007

Other lenders felt that our business had:

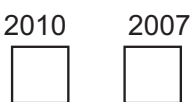

x. Poor credit rating

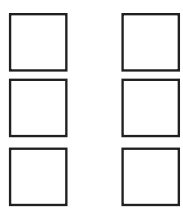

xiii. Insufficient or risky potential (of the business or project)

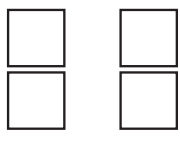

xv. No loan history

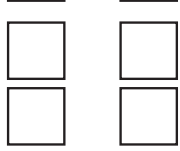

xvii. No reason given

xviii. Other reason(s)

Please specify separately for 2010 and 2007 
Question 4 continued from previous page

Please $X$ all boxes that apply for each year 20102007

\section{Our business decided that:}

xix. Interest rates offered were too high
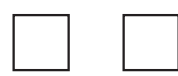

xx. Non-interest-rate related conditions of the loan were inacceptable (e.g. maturity, covenants, etc.)

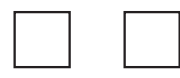

xxi Other reason(s)

Please specify separately for 2010 and 2007

5. If you sought loan finance from a bank, what were your reasons for choosing that particular bank?

Please $\quad X \quad$ all boxes that apply for each year

i. Your business was already a client. . . . . . . . . . . . . .
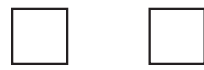

ii. The bank branch was local.

iii. The bank offered the best:

Interest rate related terms

Non-interest rate related terms
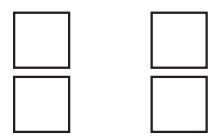

iv. The bank has an emphasis on smaller firms

v. The bank branch is known for its good client relationships

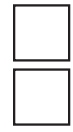

vi. Other reason(s)

Please specify separately for 2010 and 2007
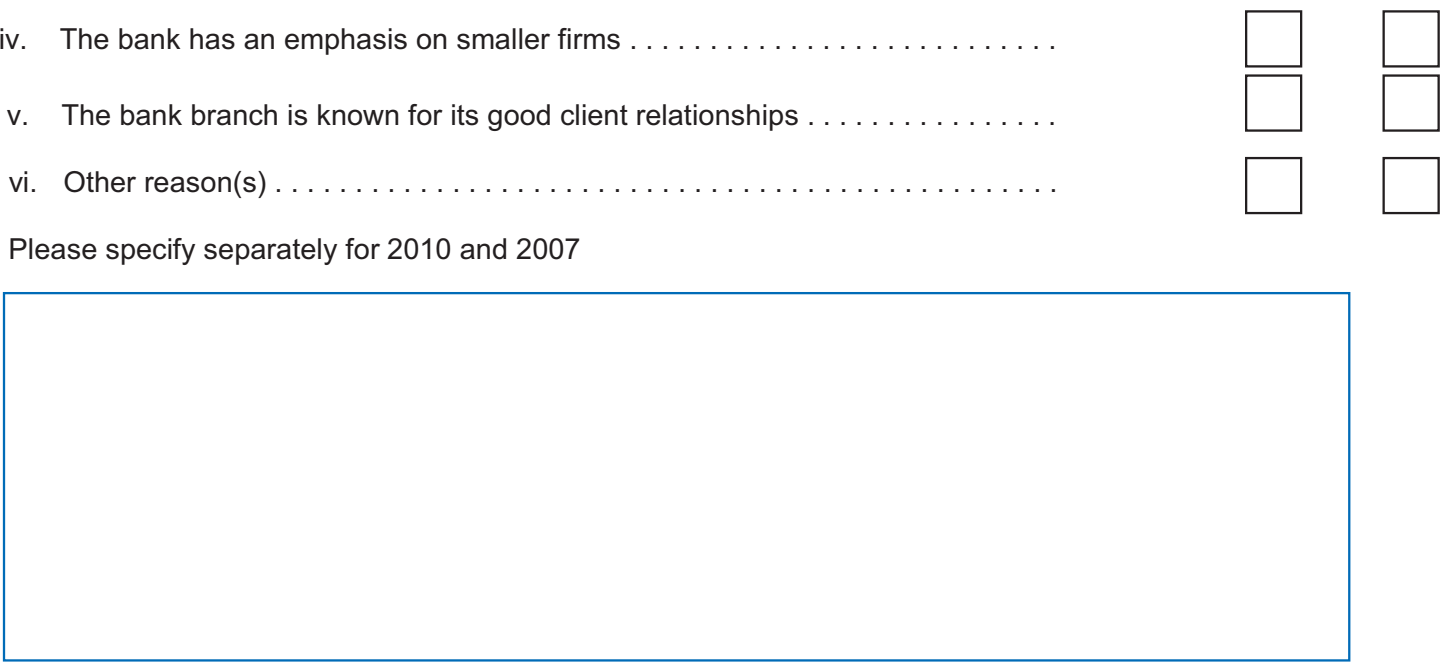


\section{Section C - Seeking Equity Finance}

This section is about your success in obtaining equity finance in 2010 and 2007.

Equity finance refers to money or other assets given against part ownership of shares.

\section{6a. In $\mathbf{2 0 1 0}$ did you seek any equity finance?}

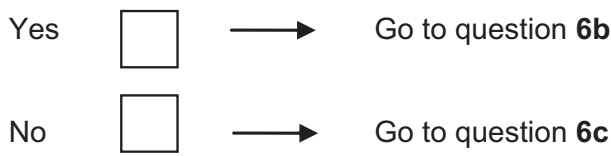

6b. How successful were you in obtaining equity finance from each of the following sources in $\underline{2010}$ ? Partially successful refers to not getting the requested amount, or not on the desired terms.

Please $X$ all that apply

$\begin{array}{ccc}\text { Successful } & \text { Partially } \\ \text { Successful } & \text { Unsuccessful }\end{array}$

i. Existing shareholders
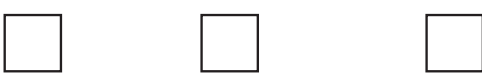

ii. Directors not previously shareholders

iii. Other employees of your business
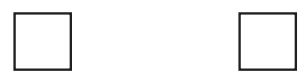

iv. Venture capital funds i.e. capital provided by investors acting together in a fund set up for the purpose of providing finance to start-up and small businesses ......
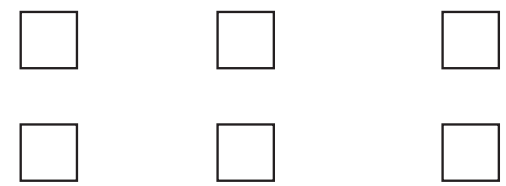

v. Business angels i.e. entrepreneurs (usually individual entrepreneurs) who provide capital for a business start-up, usually in return for owning part of the business
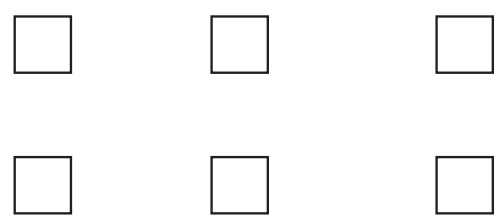

vi. Family, friends or other individuals, not any of the above

vii. Initial public offering or other stock market offerings i.e. the first issue of shares by a private company to the public in order to generate capital
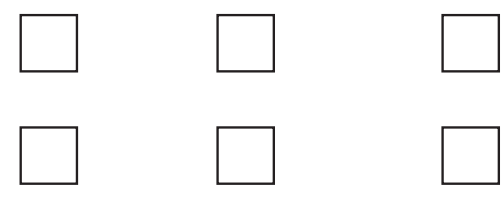

Banks
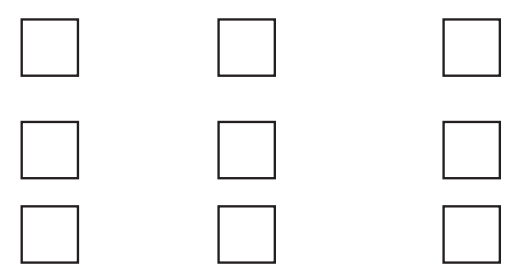
ix. Other financial institutions e.g. finance houses and subsidiaries of banks
viii. Banks .<smiles>[CH]=C</smiles>
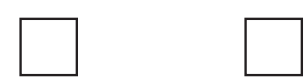

x. Other businesses $\ldots \ldots \ldots \ldots \ldots \ldots \ldots \ldots$
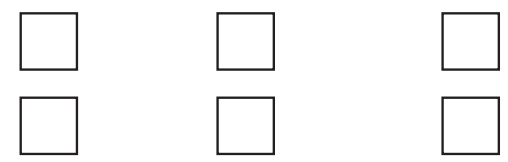

Please specify the other equity finance sources 
6c. In 2007 did you seek any equity finance?

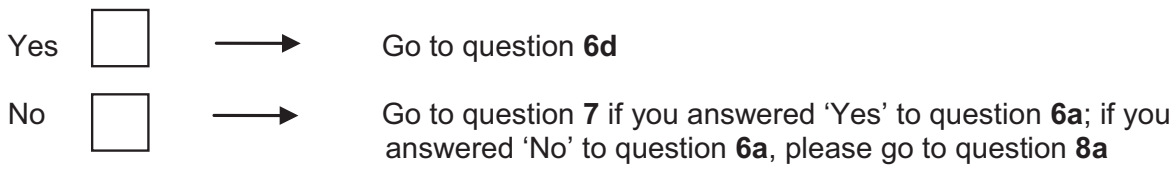

6d. How successful were you in obtaining equity finance from each of the following sources in 2007 ? Partially successful refers to not getting the requested amount, or not on the desired terms.

$$
\begin{array}{ll}
\text { Please } & X \text { all that apply } \\
\text { Successful } & \text { Partially Unsuccessful } \\
& \text { Successful }
\end{array}
$$

i. Existing shareholders $\ldots \ldots \ldots \ldots \ldots \ldots \ldots \ldots \ldots$

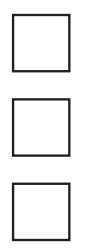

ii. Directors not previously shareholders .

iii. Other employees of your business . . . . . . . . .

iv. Venture capital funds i.e. capital provided by investors acting together in a fund set up for the purpose of providing finance to start-up and small businesses ......
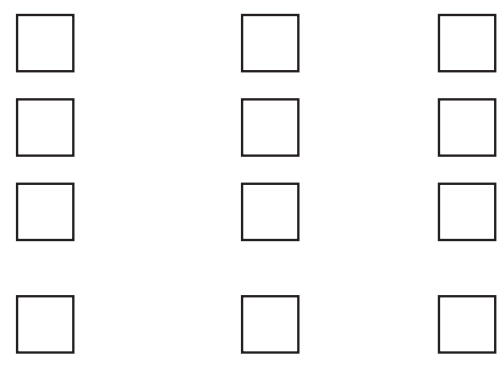

Business angels i.e. entrepreneurs (usually individual entrepreneurs) who provide capital for a business start-up, usually in return for owning part of the business . .
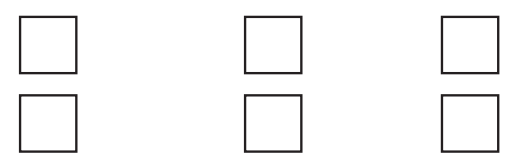

vii. Initial public offering or other stock market offerings i.e. the first issue of shares by a private company to the public in order to generate capital . . . . . . . . . . .

viii. Banks

ix. Other financial institutions e.g. finance houses and subsidiaries of banks . . . . . . . . . . . . .
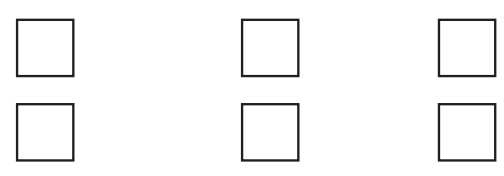

Other businesses
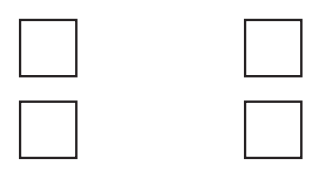

xi. Government/other equity finance sources ..........

Please specify the other equity finance sources 
7. If you were partially successful or unsuccessful (see question $6 b$ and $6 d$ ) in your request for equity finance, during the financial year ending on any date in $\mathbf{2 0 1 0}$ or 2007, what were the main perceived or communicated reasons for this?

Please $\mathrm{X}$ all boxes that apply for each year

\section{Existing shareholders:}

2010

2007

i. Did not feel able to subscribe for more shares $\ldots \ldots \ldots \ldots \ldots \ldots \ldots$

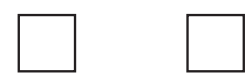

Potential new shareholders:

ii. Asked for too much equity in exchange for the funds offered . . . . . . . . .

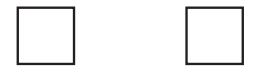

iii. Were asking for too many concessions in exchange for equity finance

iv. Felt the development potential of the business was insufficient or too risky ...

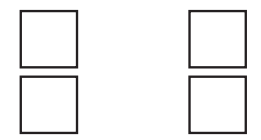

v. Felt that the business had too many debts

vi. Other reason(s) .

Please specify the other main reason separately for 2010 and 2007
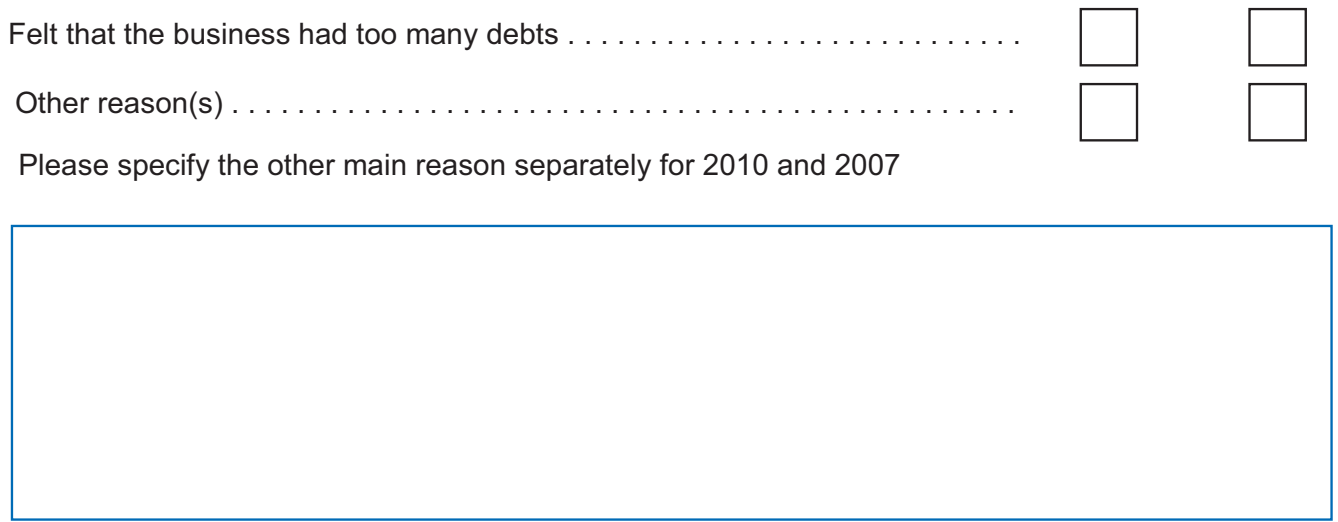


\section{Section D - Seeking other sources of finance}

This section seeks to investigate finance types and sources other than loans and equity, for the years 2010 and 2007 separately.

Other sources of finance may include leasing, factoring, bank overdraft, subsidised loans, trade credits, export finance facilities or mezzanine financing.

\section{8a. In $\mathbf{2 0 1 0}$ did you seek any other type of finance other than loans and equity finance?}

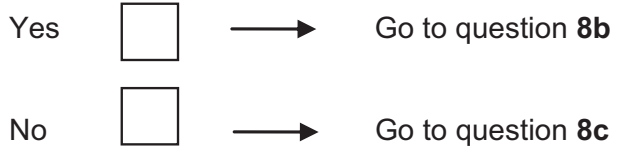

8b. How successful were you in obtaining other type of finance from each of the following sources in 2010? Partially successful refers to not getting the requested amount, or not on the desired terms.

Please $X$ all that apply

$\begin{array}{lll}\text { Successful } & \text { Partially } & \text { Unsuccessful } \\ \text { Successful } & \end{array}$

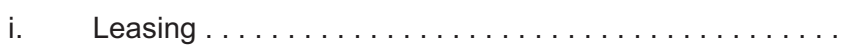
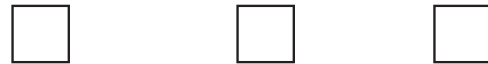

ii. Factoring .
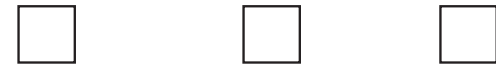

iii. Bank overdraft or credit line
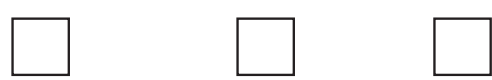

iv. Subsidised loans
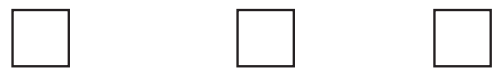

v. Subsidies by [your country's] government
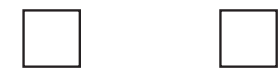

vi. Foreign government bodies or international organisations

vii. Trade credits (by suppliers) .

viii. Advanced payments (by customers)

ix. International trade or export finance facilities. . . . . . . .

x. Mezzanine or hybrid financing i.e. loan financing that gives the lender the rights to convert to an equity interest in the business if the loan is not fully repaid on time .... .
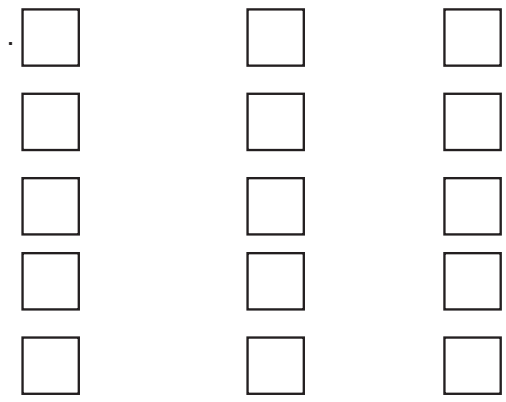

xi. Other finance types and sources
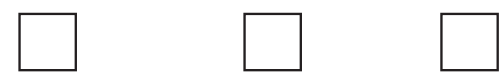

Please specify the other finance types and sources 
8c. In 2007 did you seek any other type of finance other than loans and equity finance?

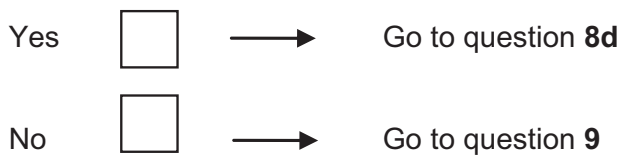

8d. How successful were you in obtaining other type of finance from each of the following sources in 2007? Partially successful refers to not getting the requested amount, or not on the desired terms.

Please $X$ all that apply

$\begin{array}{lll}\text { Successful } & \text { Partially } \\ \text { Successful } & \text { Unsuccessful }\end{array}$

i. $\quad$ Leasing $\ldots \ldots \ldots \ldots \ldots \ldots \ldots \ldots \ldots \ldots \ldots \ldots \ldots \ldots \ldots \ldots \ldots \ldots$
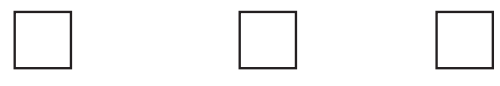

ii. Factoring .
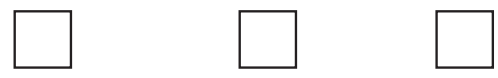

iii. Bank overdraft or credit line
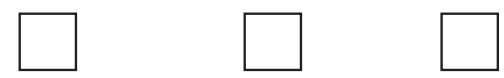

iv. Subsidised loans

v. Subsidies by [your country's] government

vi. Foreign government bodies or international organisations
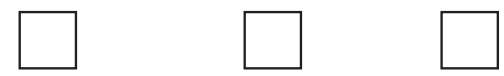

vii. Trade credits (by suppliers)

viii. Advanced payments (by customers)
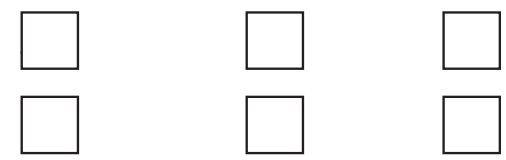

ix. International trade or export finance facilities. .........

x. Mezzanine or hybrid financing i.e. loan financing that gives the lender the rights to convert to an equity interest in the business if the loan is not fully repaid on time.....

xi. Other finance types and sources $\ldots \ldots \ldots \ldots \ldots \ldots$
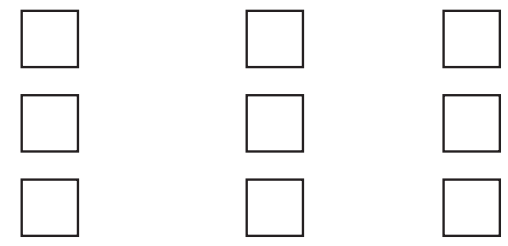

Please specify the other finance types and sources 


\section{Section E - Changes over the past three years}

This section is about your perception of changes over the past 3 years.

9. How did the following change between 2007 and 2010 ?

Please $\mathrm{X}$ one box for each row

$\begin{array}{llll}\begin{array}{l}\text { Much } \\ \text { Better }\end{array} & \text { Better Unchanged Worse } & \begin{array}{c}\text { Much No opinion } \\ \text { Worse }\end{array}\end{array}$

i. The financial situation of your business .......
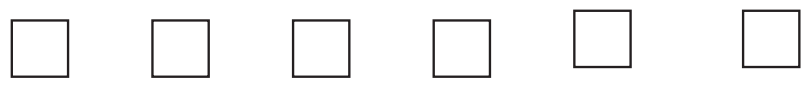

ii. The cost (interest and other) of obtaining finance for your business.
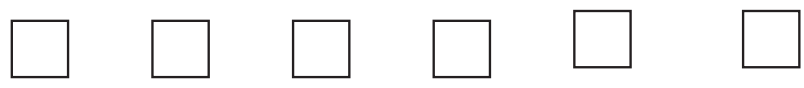

iii. The debt/turnover ratio of your business ......
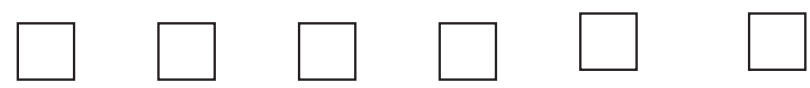

iv. Other terms or conditions of finance (e.g. maturity, covenants)
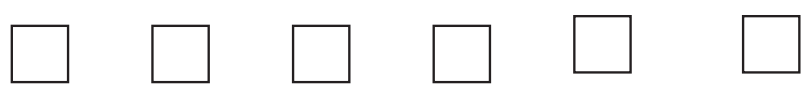

v. The burden or effort of obtaining finance for

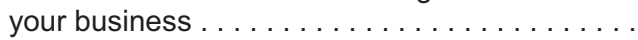
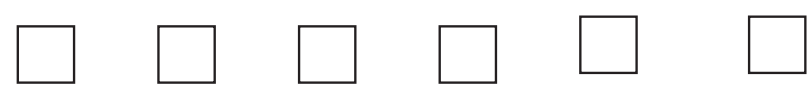

vi. The willingness of banks to provide finance ....
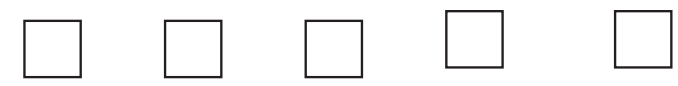

\section{Section F - Looking ahead}

This section is about your perception regarding finance and potential obstacles to the growth of the business over the next 3 years.

Between now and 31 December 2013:

10a. Are you likely to need finance?

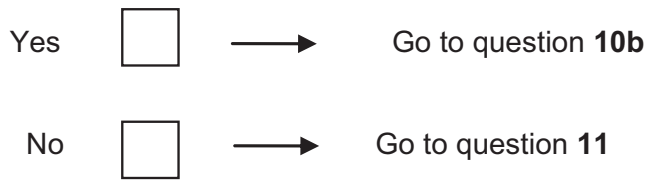

10b. What type(s) of finance are you likely to need?

Please $X$ all that apply
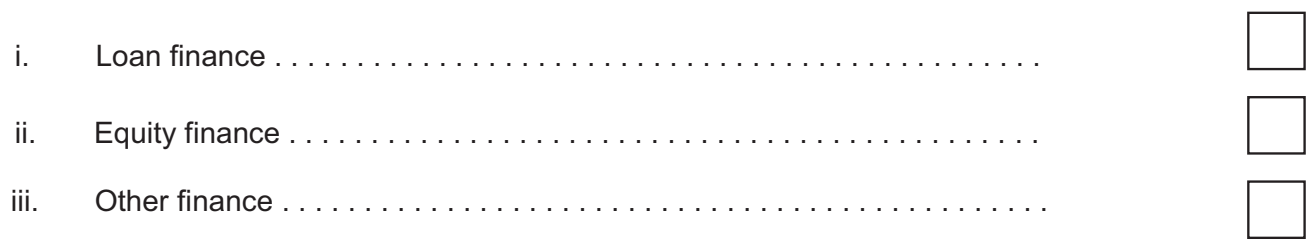
10c. Where do you expect to obtain the finance from?

i. The owner(s)/director(s) of your business .

ii. Other employees of your business

iii. Family, friends or other individuals outside your business, excluding business angels

iv. Other businesses

v. Leasing companies

vi. Banks

vii. Other financial institutions

viii. Mezzanine or hybrid financing i.e. loan financing that gives the lender the rights to convert to an equity interest in the business if the loan is not fully repaid on time . . . . . . . .

ix. Venture capital funds i.e. capital provided by investors acting together in a fund set up for the purpose of providing finance to start-up and small businesses $\ldots \ldots \ldots \ldots \ldots \ldots$

x. Business angels i.e. entrepreneurs (usually individual entrepreneurs) who provide capital for a business start-up, usually in return for owning part of the business . . . . . . . . . . .

xi. An initial public offering or other stock market offerings i.e. the first issue of shares by a private company to the public in order to generate capital .

xii. A government body within [your home country]

xiii. Foreign government bodies or international organisations

xiv. Other finance sources

Please specify the other loan sources 
10d. What would be the purpose of the finance?

Please $\mathrm{X}$ all that apply

i. Maintain the business as a going concern

ii. Grow the business's domestic activities

iii. Finance export sales

iv. Finance innovation and R\&D

v. For mergers and acquisitions

vi. Develop international activities

vii. Other purpose(s)

Please specify the other purpose(s) 
Between now and 31 December 2013:

11. Which of the following are likely to be the most important factors limiting the growth of the business?

Please $\mathrm{X}$ up to five most relevant response categories

i. General economic outlook

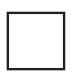

ii. Limited demand in the local/domestic markets

iii. Limited demand in foreign markets

iv. Limited availability of suitable new personnel.

v. Loss of existing personnel

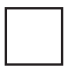

vi. Business transfer problems e.g. inheritance

vii. High cost of labour

viii. Necessary investment into equipment etc

ix. Products getting outdated (R\&D necessary, product lead time)

x. Technological competition.

xi. New entrants in the market

xii. Price competition/small margins

xiii. Regulatory framework

xiv. Lack of fiscal incentives

xv. Difficult access to information technology (e.g. broadband).

xvi. Other infrastructure weakness.

xvii. Not enough financing.

xviii. Do not see any constraints (nothing ticked above) 


\section{Section G - Comments, administrative burden and contact details}

12. In the box below, please write any additional comments that you would like to make.

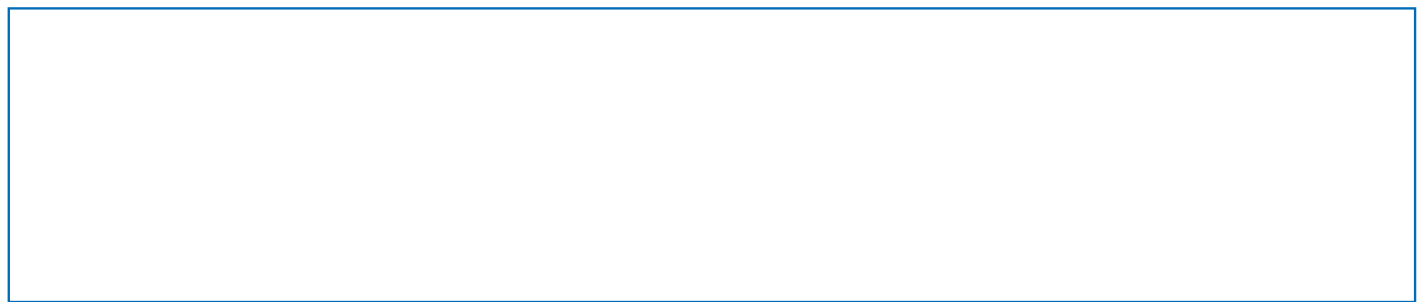

13. Please give details of the person we should contact if we have any queries regarding the information returned on this questionnaire.

Contact

Name

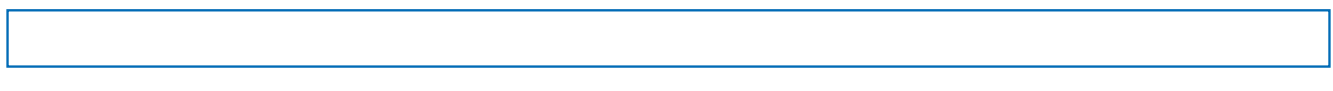

Position in

Business

Telephone

Number
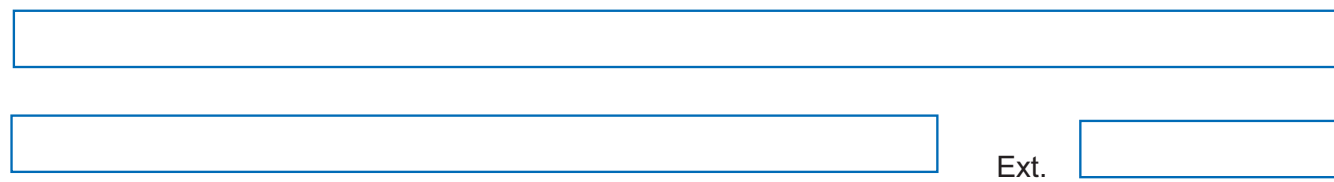

Ext.

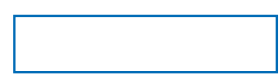

14. How long has it taken you to complete this questionnaire?

Minutes

Thank you for completing the questionnaire 


\section{ANNEX C \\ Grossing up Techniques}

\section{Simple grossing-up for each cell of the questionnaire}

Question by question, the number of responses in the cell is multiplied by the ratio of the number of respondents eligible to the question compared with the number of respondents to the question.

Let $h=1, \ldots, H$ denote the strata. The grossed-up total for a peculiar cell $c$ of question $q$ in stratum $h$ is defined by:

$$
\hat{t}_{h q c}=\frac{N_{h}}{n_{r, h q}} \sum_{i=1}^{n_{r, h q}} y_{h q c i},
$$

where $n_{r, h q}$ is the number of respondents to question $q$ in stratum $h, y_{h q c i}$ is the response of unit $i$ in stratum $h$ to cell $c$ of question $q$ ( 1 if the unit tick this cell, 0 otherwise) and $N_{h}$ is the number of eligible businesses in stratum $h$.

\section{Applying some form of correction}

In the case that the respondents in the stratum do not reflect the size structure of the stratum, one additional subdivision can be made, for example, separating the stratum by employment size band, and applying simple grossing for each.

Let denote $g=1, \ldots G_{h}$ the different groups. The estimated total is then:

$$
\hat{t}_{h q c}=\sum_{g=1}^{G_{h}} \sum_{i=1}^{n_{r}, g q} \frac{N_{h}}{n_{h}} \frac{n_{g}}{n_{r, g q}} y_{g q c i}
$$

where $N_{h}$ is the number of units in the population in stratum $h, n_{h}$ is the number of units sampled in stratum $h, n_{g}$ is the number of sampled units in group $g, n_{r, g q}$ is the number of respondents to question $q$ in group $g$ and $y_{\text {gqci }}$ is the response of unit $i$ in group $g$ to cell $c$ of question q.

\section{Using an auxiliary variable}

For example, employment or turnover can be used to calculate estimated totals by applying a weight to each stratum. 
Let $h=1 \ldots H$ denote the strata and $x$ the auxiliary variable. The estimated total in a stratum $h$ for a cell $c$ of question $q$ is given by:

$$
\hat{t}_{h q c}=\frac{N_{h}}{n_{r, h q}} \sum_{i=1}^{n_{r, h q}} g_{h q} y_{h q c i} \text {, with the g-weight: } g_{h q}=\frac{n_{r, h q}}{N_{h}} \frac{\sum_{j=1}^{N_{h}} x_{j}}{\sum_{i=1}^{n_{r, h q}} x_{h i}}
$$

where $x_{h i}$ is the value of the auxiliary variable for unit $i$ in stratum $h, n_{r, h q}$ is the number of respondents to question $q$ in stratum $h, y_{\text {hqci }}$ is the response of unit $i$ in stratum $h$ to cell $c$ of question $q$ ( 1 if the unit tick the cell, 0 otherwise), and $N_{h}$ is the number of units in the population in the stratum $h$. 


\section{ORGANISATION FOR ECONOMIC CO-OPERATION AND DEVELOPMENT}

The OECD is a unique forum where governments work together to address the economic, social and environmental challenges of globalisation. The OECD is also at the forefront of efforts to understand and to help governments respond to new developments and concerns, such as corporate governance, the information economy and the challenges of an ageing population. The Organisation provides a setting where governments can compare policy experiences, seek answers to common problems, identify good practice and work to co-ordinate domestic and international policies.

The OECD member countries are: Australia, Austria, Belgium, Canada, Chile, the Czech Republic, Denmark, Estonia, Finland, France, Germany, Greece, Hungary, Iceland, Ireland, Israel, Italy, Japan, Korea, Luxembourg, Mexico, the Netherlands, New Zealand, Norway, Poland, Portugal, the Slovak Republic, Slovenia, Spain, Sweden, Switzerland, Turkey, the United Kingdom and the United States. The European Union takes part in the work of the OECD.

OECD Publishing disseminates widely the results of the Organisation's statistics gathering and research on economic, social and environmental issues, as well as the conventions, guidelines and standards agreed by its members. 


\section{Entrepreneurship at a Glance 2012}

This second issue of Entrepreneurship at a Glance, a product of the OECD-Eurostat Entrepreneurship Indicators Programme, presents an original collection of indicators for measuring the state of entrepreneurship, along with explanations of the policy context and interpretation of the data. New to this issue are special chapters addressing measurement issues on women entrepreneurship and entrepreneurial finance, as well as selected indicators on women entrepreneurship.

\section{Contents}

Recent trends in new firm creations and bankruptcies

\section{Measuring entrepreneurship}

Measuring women entrepreneurship

Measuring entrepreneurial finance: A European survey of SMEs

\section{Entrepreneurship indicators}

Structural indicators on the enterprise population

Enterprise birth, death and survival

Employment creation and destruction

Enterprise growth

Women entrepreneurship

Determinants of entrepreneurship: Selected indicators

\section{2}

